\title{
1108907
}

SELMA MARTINEZ SIMÕES RODRIGUES DEE LARA

\section{Formando caminhos para uma Educação em Valores Humanos: a importância da Literatura}

Dissertação de Mestrado apresentada à Faculdade de Educação da Universidade de São Paulo, sob orientação da Profa. Dra. Marieta Lúcia Machado Nicolau. Área de concentração: Psicologia e Educação

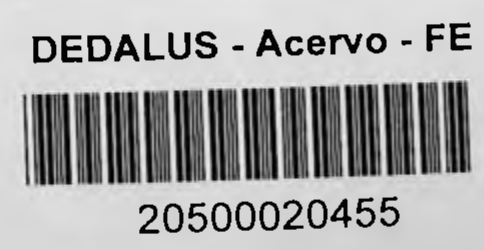

São Paulo 2000 


\section{Índice}

$\begin{array}{ll}\text { Agradecimentos } & 4\end{array}$

Resumo $\quad 7$

Summary 9

$\begin{array}{ll}\text { Introdução } & 11\end{array}$

Capítulo 1

$\begin{array}{ll}1.1 \text { - As memórias ...raizes de toda história... } & 18\end{array}$

- Minhas memórias de infância

1.2 - As memórias de infância e a influência na formação do professor/educador 21

1.3 - As memórias de professores/educadores 23

1.4 - Sondagem sobre as memórias de infância de professores/educadores das 24 redes de ensino público (municipal) e particular

1.5 - Reflexōes a partir dos comentários de professores/educadores 35

1.6 - Leitura e memória 38

Capítulo 2

2.1 - Ser professor /educador / mestre...Por quê? Para quê? Como? 44

- Consideraçōes sobre a formação docente

2.2 - Momento de reflexão: histórias dedicadas a professores/educadores

Capitulo 3

3.1 - Questões sobre concepção: a criança na história e a história da criança 57

3.2 - Educação Infantil e Pré-escola: reflexões sobre a criança pequena 60

3.3 - O professor/ educador da criança pequena $\quad 65$

3.4 - Desenvolvimento infantil: a importância da literatura 67

Capitulo 4

4.1- O cerne de toda a história... Afinal, o que è literatura?

4.2 - Literatura: eixo central da história - não é nem deve ser pretexto 75

4.3 - Literatura infantil e a construção do ser: múltiplas aprendizagens 78

4.4 - Caminhos possiveis para uma escola prazerosa: Educação-literatura e 81 psicanálise 
Capitulo 5

5.1 - A formação moral da criança: Ética nos Parâmetros Curriculares Nacionais 87 e no Referencial Curricular Nacional para a Educação Infantil

5.2 - O desenvolvimento moral da criança 92

5.3 - A Educação Moral no contexto escolar 96

5.4 - Educação em Valores Humanos 100

5.5 - Programa de Educação em Valores Humanos: reflexões a partir de algumas 106 histórias infantis

5.6 - Projeto de Literatura Infantil e Valores Humanos: vivenciando histórias com 116 as crianças antes e depois da alfabetização

- Primeiro momento da pesquisa: a implementação do projeto - $2^{\circ}$ semestre de 1998

- Reflexões ao encerrar as sessões para a implementação do projeto 168

- Segundo momento da pesquisa: a retomada do projeto na trajetória das crianças envolvidas (a influência do processo de alfabetização) - $1^{\circ}$ semestre de 2000

- Reflexões ao encerrar as sessões de retomada do projeto

Considerações finais

Bibliografia

Anexo:

Projeto Literatura Infantil: uma viagem de transformação através dos Valores Humanos

- Primeiro momento - implementação do projeto: figuras e fotos:

- Segundo momento - retomada do projeto: desenhos e atividades das crianças 224 na pesquisa longitudinal (alguns exemplos). 
- Deu-me Deus o seu gládio porque eu faça

A sua santa guerra

Sagrou-me seu em honra e em desgraça,

$\dot{A}$ s horas em que um frio vento passa

Por sobre a fria terra

Pôs-me as mãos sobre os ombros e doirou-me

A fronte com o olhar.

E esta febre de Além, que $m$ consome,

E este querer grandeza são seu nome

Dentro de mim a vibrar

E eu vou, e a luz do gládio erguido dá

Em minha face calma

Cheio de Deus, não temo o que virá,

Pols, venha o que vier. nunca será

Maior do que a minha alma

Fernando Pessoa

\section{Agradecimentos Especiais}

A meus pais, Antônio e Regina, pela vida, pelo amor e pelo incentivo para continuar sempre.

A Márcio,

companheiro de todas as horas, pela força constante, pelo carinho

e pela compreensão. no percorrer desta trajetória. 
Talvez não tenhamos conseguido fazer o melhor, mas lutamos para que o melhor fosse feito... Não somos o que deveriamos ser, não somos o que iremos ser. Mas, graças a Deus, não somos o que éramos.' Martin Luther King

às crianças,

co-participantes desta pesquisa e razão maior de sua realização;

à Profa. Dra. Marieta Lúcia Machado Nicolau, orientadora deste trabalho - companheira constante, exemplo de vida, humildade e sabedoria - pelo incentivo, carinho, dedicação e compreensão;

aos professores/ educadores e equipes técnicas das escolas, colaboradores e incentivadores na realização desta pesquisa;

à diretora do

Colégio Nascimento,

Telma Gomes do Nascimento Tavares,

pela amizade, pela oportunidade concedida e pela colaboração demonstrada na participação da pesquisa realizada em sua escola;

às bibliotecárias da Faculdade de Educação da USP, do Centro Universitário Monte Serrat e da Secretaria Municipal de Educação de Santos,

pelo acompanhamento do trabalho, incentivo e parceria no levantamento bibliográfico indicado para esta pesquisa; 
aos amigos da Secretaria Municipal de Educação de Santos,

pela força constante, pelo imenso companheirismo, pela troca de experiências e pelo apoio para a realização deste trabalho;

aos amigos dos cursos de pós-graduação e de especialização em Educação Infantil da Faculdade de Educação da USP,

pelas trocas de significativas experiências, pelo amizade, carinho e incentivo e por acreditar na realização desta pesquisa;

aos funcionários da secretaria de pós-graduação e do apoio acadêmico da Faculdade de Educação da USP

pelo acompanhamento da trajetória e incentivo constante para a realização deste trabalho:

aos professores das disciplinas de pós-graduação cursadas para o encaminhamento desta pesquisa,

Marieta Lúcia Machado Nicolau, Idméa Semeghini-Siqueira, Leny Magalhães Mrech, Maria Adélia Ferreiro Mauro, Mary Julia Martins Dietzsch e Manoel Oriosvaldo de Moura,

pela dedicação e profissionalismo no incentivo à realização desta pesquisa e pelo oferecimento de subsidios para a elaboração do trabalho;

aos professores do curso de Especialização em Educação Infantil da Feusp,

Marieta Lúcia Machado Nicolau, Nelly Novaes Coelho, Marina Célia Moraes Dias, Lenira Haddad, Maria Felisminda de Rezende e Fusari (in memorian), Maria Heloisa Corrêa de Toledo Ferraz, Heloysa Dantas, Marta Kohl de Oliveira, Jerusa Vieira Gomes, Tizuko Morchida Kishimoto, Ana Lúcia Goulart de Faria, Nelio Bizzo, Sylvia Maestrelli, Isabel Marques, Iveta Maria Borges Ávila Fernandes, Marcos Garcia Neira, Mauro Gomes de Mattos, Karen Mülle, Manoel Oriosvaldo de Moura e Regina de Moura,

pela oportunidade de ampliar a pesquisa em Educação Infantil, pelo constante incentivo e pelo oferecimento de subsidios para a realização deste trabalho;

a todos que, direta ou indiretamente,

colaboraram e contribuiram para a realização desta pesquisa e elaboração deste trabalho e que a memória, porventura, tenha ocultado a lembrança, nosso sincero agradecimento. 


\section{Resumo}

Esta pesquisa visa ressaltar a importância da Literatura na elaboração de caminhos para a vivência e formação de Valores Humanos

Como parte integrante da história da humanidade, a Literatura guarda, em seu mais profundo significado, o registro de fatos passados, presentes e continua, ainda, a sua preciosa trajetória em direção aos fatos projetados ao futuro.

Professores/educadores e alunos/educandos beneficiam-se da riqueza literária oferecida pelas inusitadas histórias que revelam o delineamento de vias de incontestável valor para o processo de ensino-aprendizagem, colaborando, especialmente, para a formação de principios éticos indispensáveis à construção da personalidade moral do ser.

Sendo assim, os assuntos que serão abordados nesta dissertação foram organizados em cinco capitulos concatenados e inter-relacionados ao tema desta pesquisa

No capitulo 1, apresenta-se uma discussão sobre a importância das memórias de infância de alguns professores/educadores e a (re)significação destas em sua formação profissional. Esta abordagem é ilustrada por meio de entrevistas com alguns educadores de escolas públicas da Rede Municipal de Ensino de Santos - SP e de uma escola da Rede Particular de Ensino de São Vicente - SP.

No capitulo 2, são feitas considerações sobre a formação docente, com apresentaçāo de algumas histórias significativas que visam levar à reflexão sobre a atuação de professores/educadores, ressaltando exemplos de alguns escritores/contribuidores oportunos para o enfoque do tema.

No capitulo 3, é ressaltada a importância da concepção de criança e de sua história na história... aliada à importância da Educação Infantil como a fase basilar para a formação deste ser e o seu 'pensar', enfatizando o valor do primeiro contato estabelecido com as histórias do mundo da Literatura: momento decisivo para a sedução e conquista do futuro leitor.

No capitulo 4, a Literatura Infantil aparece como elemento central e desencadeador de múltiplas aprendizagens, já que possui importância indiscutivel em si mesma, sem servir de pretexto para quaisquer discussões que se pretenda fazer, pois ela, por si só, se basta, sendo soberana em sua natural amplitude, possibilitando ramificar inúmeras reflexões capazes de serem aprofundadas a partir de sua transcendência.

No capítulo 5, são abordadas questões relacionadas à formação moral da criança, enfatizando os aspectos do desenvolvimento moral e da Educação Moral no contexto escolar, ilustrados por meio de uma proposta teórico-prática de Educação em Valores Humanos. Trata-se de reflexões com alguns exemplos possiveis que já vêm sendo aplicados no PEVH (Programa de Educação em Valores Humanos) criado há trinta anos por Sathyia Sai Baba, na Índia e, atualmente, difundido em escolas de, aproximadamente, 130 paises. 
Ainda com referência ao capítulo 5, apresentamos uma discussão sobre a aplicação da Educação em Valores Humanos através da Literatura, com a implementação de um projeto desenvolvido em uma escola de Educação Infantil, em São Vicente - SP - com crianças de 5 a 6 anos de idade (ainda não alfabetizadas), em um primeiro momento, no nível Pré-escolar - e a retomada da pesquisa - com as mesmas crianças, em um segundo momento, com 7 e 8 anos de idade (a maioria das quais já alfabetizadas ou em processo de alfabetização), no Ensino Fundamental - visando à observação destas, através de um estudo longitudinal, na tentativa de detectar a intensidade de interesse demonstrado na vivência de diversas histórias apresentadas no decorrer da trajetória e dos Valores Humanos experienciados - assim como a (re)significação destes fatores combinados para as crianças nos dois momentos (início e retomada) desta pesquisa.

Esta pesquisa tem como propósito mostrar que a Literatura constitui-se como um veiculo mediador de extrema valia para a construção de seres melhores em um mundo também melhor, na busca da paz, do equilíbrio, da justiça e da criticidade, ou seja, de Valores Humanos que garantam a todos a apropriação do verdadeiro sentido da cidadania com alegria, que jamais se dissocia do verdadeiro sentido da Educação. 
This research aims to show the importance of literature to an elaboration of ways that look at the experimentation and structuration of Human Values.

As an integrant part of humanity history, literature keeps, in its deep meaning, the register of past facts, the present ones and, still, keeps on its precious journey straight ahead the facts projected to future

Teachers/educators and pupils/students are beneficiaries at the literary wealth offered by the peculiar stories that reveal an outline of unquestionable value to teaching-learning process, contributing, specially, to the structuration of ethic principles indispensible to the building of being moral personality.

By this way, the subjects that will be discussed under this dissertation were organized in five congregated and combined chapters related to this research's theme.

Chapter 1 presents a discussion about the importance of childhood memories of some teachers/educators and the re-meaning of these memories in their professional formation. This approach is illustrated by interviews with some educators of public schools of Santos - SP Teaching Municipal System and a private school that belongs to the Teaching Private System of São Vicente - SP.

Chapter 2 provides considerations about teaching formation, offering some meaningful stories that seek for a reflection concerning to teachers/educator's practice, reinforcing examples of some writers/contributors to the theme.

Chapter 3 shows the importance of child's conception and her story in history... allied to the importance of Childish Education as a basilar phase to the formation of this being and her 'thought', emphasizing the value of the first contact established with the literature world stories: decisive moment to the seduction and conquest of the future reader.

Chapter 4 presents Childish Literature as a central element responsible for multiple learnings, according to its self indisputable importance, without being considered as a pretext to any other discussions that one decides to do, because it is sovereign on its natural amplitude, offering a lot of reflections that can be studied deeply based on its transcendency.

Chapter 5 approaches questions related to the child moral formation, emphasizing the aspects of moral development and Moral Education at scholastic environment, that are illustrated by means of a theoretical-practical purpose of Human Values Education. Some reflections are presented based on possible examples that are already being used in the PEVH (Human Values Education Program) that has been created for thirty years ago by Sathyia Sai Baba, in India and, nowadays, is being applied in schools around 130 countries.

According to Chapter 5, we still present a discussion about the aplication of a Human Values Education by means of literature, with the implementation of a project developed in a kindergarten school, located in São Vicente - SP - . 
including 5 and 6 years old children (not literate yet), in a first moment, in preschool level - and the research retaking, with the same students, in a second moment, 7 and 8 years old children (most of them literate or in process of being literate), in elementary school level - , aiming to the observation of these children, by means of a lasting study, seeking for verifying the interest demonstrated in experimentation of different stories presented to children on the journey and the Human Values that were lived by them - as well as the re-meaning of these factors combined to children in two moments (beginning and retaking) of this research.

This research has as purpose to show that literature can be regarded as a mediator vehicle of extreme worth to the structuration of better human beings in a better world, in the search of peace, balance, justice and criticism, that is, in the search of Human Values that can offer to everybody the meaning of citizenship with jolliness, that is never separated from the true meaning of Education. 
Trabalhar como professora de educação infantil, ensino fundamental e médio, desde 1984. e, mais recentemente, com o ensino superior, tem-me proporcionado a oportunidade de vivenciar a prática docente em vários niveis de ensino

O convivio com as crianças, com os adolescentes e, também com adultos, foi, aos poucos, mostrando-me a importância de se investir, nas mais variadas faixas etárias, nas relações intra e interpessoais, ou seja, nos aspectos referentes ao conhecimento deles próprios voltado para o seu "eu" interior e deles, como sujeitos sociais, no conhecimento voltado para o "outro".

Tenho confirmado, para mim mesma, que a base inicial para o trabalho com as emoções e relações, dentro e fora do contexto escolar, encontra-se na Educação Infantil, pois esta constitui-se como a primeira etapa do desenvolvimento do ser e que, portanto, representa um importante alicerce para a construção do equilibrio socioemocional da criança. já que se apresenta, por meio de pesquisas comprobatórias, como um momento de grande plasticidade do sistema nervoso em formação.

Para muitos pesquisadores, a Educação Infantil, ainda conhecida popularmente como pré-escola, é a fase indispensável para a aquisição de múltiplas formas de saber. Este momento deve ser valorizado pela importância que apresenta em si mesmo e não como suporte para outros niveis de ensino; no entanto, é evidente que, se bem trabalhado, favorecerá, inevitavelmente, a trajetória de momentos subseqüentes da vida escolar.

A Educação Infantil visa considerar a criança de maneira integral, oferecendo oportunidades para que ela se desenvolva nos aspectos psicomotor $e$ social, sem estabelecer quaisquer rupturas na operacionalização deste processo indissociável

Dessa forma, a caminhada como professora tem-me ajudado a perceber que o mundo simbólico e imagético da criança caracteriza-se como uma valiosa ponte de ligação para que nos aproximemos delas, por meio de recursos relacionados à imaginação, à criação e à magia do faz-de-conta, de forma natural e significativa. Neste particular, a literatura, como elemento milenar da história da humanidade, facilitador e responsável pelo encantamento da criação e da imaginação, caracteriza-se, ainda, como elemento indispensável para o trabalho com as relações intra e interpessoais, baseado nas histórias que oportunizam à criança múltiplas vivências de papéis através das personagens apresentadas.

No dia-a-dia da criança, ela oferece ao professor, através de sua oralidade, inúmeras 'pistas' que traduzem o que ela vivencia em seu momento próprio e peculiar. O professor atento, que apresenta um olhar diferenciado e cuidadoso em relação à criança, precisa esforçar-se para ser perspicaz e sensivel, a fim de interpretar as mensagens transmitidas, visando conhecer e decifrar informaçöes, muitas vezes subliminares, captadas pelo tom da voz de seu aluno, pela repetição 
de algumas palavras ou expressões enfatizadas, e, até mesmo, pela ausência ou pouca manifestação de sua fala. ${ }^{1}$

O trabalho com a literatura estimula a reflexão através de mensagens transmitidas pela vivência dos personagens, pelo desenrolar da narrativa, pelas situações das mais variadas ordens, capazes de proporcionar à criança a construção de pontes comparativas com a sua própria vida, de modo consciente ou inconsciente, auxiliando-a na estruturação de seu verdadeiro "eu" e das relações com o mundo.

Considerando-se as múltiplas linguagens expressivas da criança e as infinitas possibilidades de criação, por meio da literatura, busquei alternativas de ação para enriquecer este trabalho com argumentos teóricos comprobatórios de minha pesquisa e, ao mesmo tempo, procurei não me distanciar da aplicação consistente, destes, na prática docente

Felizmente, a leitura sempre foi minha aliada na demonstração de estratégias auxiliadoras para a reflexão sobre a práxis e, acredito, que ela também pode auxiliar a criança no sentido de se perceber no mundo, oferecendo exemplificações de procedimentos na ação individual e coletiva.

Mesmo as crianças não alfabetizadas devem ser estimuladas a estabelecerem um contato com o mundo da leitura, envolvendo toda a gama da magia, do fantástico, da imaginação, do faz-de-conta, da criação e do pensar. Neste sentido, a arte de ouvir e contar histórias marca a trajetória da humanidade, apropriando-se desta riqueza milenar da literatura, passada de geração para geração.

A literatura vale por si mesma e apresenta por si só o conhecimento do mundo. O objetivo deste trabalho não é, de forma alguma, usá-la como meio e nem pretexto para atingir outros fins. Contudo, a partir de sua utilização, percebemos aspectos indispensáveis para a nossa reflexão como educadores e, também, para sua implementaçāo na prática escolar como um possivel veículo desencadeador de atividades ricas e significativas, imprescindiveis à criança em sua vida cotidiana.

\footnotetext{
"A criança quando chega à escola, por volta dos 6 anos, já vem sabendo e falando o portugues. Essa capacidade lingüistica exercita-se e cresce, natural e espontaneamente, sem necessidade de recorrer à explicitação e/ou memorizaçăo de regras. Essa faculdade humana para a linguagem relaciona-se à estrutura cognitiva e está na dependéncia também dos estímulos do ambiente aos quais o falante está exposto - portanto, estrutura cognitiva e meio ambiente estimulante săo condiçסes para que essa capacidade se especifique, ganhe diversidade e se torne permanente. Entretanto, essa produtividade lingüistica da criança é geralmente desconsiderada pela escola, que vê nessa fala as marcas de uma realidade lingüistica năo compativel com o padrăo de linguagem por ela adotado. Desconsiderando a linguagem da criança, a escola bloqueia a possibilidade de se instaurar o processo de interaçăo verbal em que a valorizaçăo dessa aprendizagem lingúística primeira da criança, bem como as marcas sócio-culturais de sua linguagem, sejam tomadas como matéria-prima para a aquisiçăo e desenvolvimento da modalidade escrita da língua... Em todos os momentos em que as atividades estejam de desenvolvendo, o processo de interaçåo professor/criança, criança/criança - estará privilegiando a expressăo e a comunicaçăo oral. Expressão de personalidades diferentes que representam formas de socializaçăo também bastante diversificadas, dal a importância de se estabelecer na interaçăo verbal o equilibrio e o respeito pelas diferenças notadas entre os parceiros desse intercámbio". (NICOLAU \& MAURO, 1986: pp. 13, 21).
} 
Alguns pontos relevantes na abordagem deste trabalho, em relação à importância da literatura infantil na construção do ser e de seu saber, merecem ser destacados, priorizando a integração indiscutivel da cognição e afetividade no desenvolvimento da criança

Assim, foi realizada uma pesquisa téorico-prática, que partiu de leituras correlatas ao tema proposto, apoiando-se em uma sondagem sobre a aplicação real do mesmo, em algumas escolas de Educação Infantil das redes pública (municipalSantos/SP) e particular (Sāo Vicente/SP), por meio de depoimentos e relatos colhidos no contato com as crianças e seus professores, sendo entrevistados seis educadores - três de cada uma das referidas redes de ensino

Trata-se de uma pequena mostra exemplificadora na tentativa de ilustrar as abordagens apresentadas neste trabalho, já que o número extensivo de escolas acabaria extrapolando o objetivo reflexivo do mesmo, que não diz respeito à quantidade dos fatos, mas à sua comprovação, por meio de uma discussão qualitativa, relacionada ao contexto da realidade escolar

Dessa forma, o que se buscou, em relação à pesquisa teórico-prática, foi ressaltar a literatura infantil

- como veiculo de adaptação da criança ao meio escolar;

- como facilitador na execução do trabalho docente;

- como estratégia aproximadora entre os pais e a escola (função social da leitura e valorização dos padrões culturais);

- como elemento comprobador das múltiplas inteligências humanas nas diferentes faixas etárias e em ambientes sociais variados;

- como fator desencadeador de situações-problema a serem expostas ao público infantil com o intuito de se exercitar o 'pensar' da criança;

- como canal do autoconhecimento infantil, facilitando, simultaneamente, sua integração social com base na vivência de valores humanos;

- como elemento gerador da criação (oral ou gráfica) de novas histórias.

Aproveitando os aspectos abordados, anteriormente, é importante ressaltar que o objetivo principal deste trabalho é oferecer a literatura à criança de maneira prazerosa e estimulante, para que esta fonte de saber se constitua como uma prática constante na vida dentro e fora da escola, e, mesmo depois desta. $E$, ainda, voltando à preocupação inicial desta exposição, buscar subsidios prioritários para o enriquecimento e aprimoramento das relações infantis.

Considerar a literatura infantil e os valores humanos como inerentes à formação do ser parte do fato de que ambos fazem parte da história da humanidade e retratam a evolução do homem, com registros diferenciados, de forma marcante para o aprimoramento das relações humanas em geral.

Um fator de desequilibrio do contexto de globalização que estamos vivendo atualmente, remete-nos a uma questão crucial: a consideração do outro nas relações cotidianas. Para tratarmos do global, precisamos lidar e refletir sobre o que há de imediato na situação local. Neste ponto, aparece de forma marcante a importância dos valores humanos na formação do ser, seja ele professor, aluno, pai, 
mãe, diretor etc. E isso pode começar a ser trabalhado no dia-a-dia da escola de forma simples, mas consistente e gradativa, atingindo, aos poucos, as várias áreas do convivio calcado na rotina.

\section{Como referência de INOUE (1999):}

" $\dot{A}$ medida que o desenvolvimento da criança vai se ampliando, ela reconhece o comportamento dos outros, e a sociedade, em diversos momentos de sua socialização, vai mostrando que há comportamentos mais apropriados ou esperados e outros, menos. Começam a ser criados alguns parâmetros que fazem que ela paute sua conduta em sintonia com a dos outros. Então esses parâmetros são aquilo que chamamos de 'valores'. E uma questão de conhecimento. Nós temos de saber o que incomoda o outro e o resultado dessa interação, desse intercâmbio de experiências comuns." (p.28).

$\dot{E}$ importante enfocar o papel significativo da educação infantil: edificando e alicerçando, desde a mais tenra idade, os conhecimentos e valores humanos necessàrios à sua caminhada pela vida.

É evidente, em nossos dias, um considerável despreparo de muitos pais, educadores e adultos. em geral, para lidar com a formação das crianças, talvez devido à defasagem de bases consistentes em sua própria formação e, principalmente, por não conseguirem acompanhar o ritmo alucinante de uma sociedade capitalista

Um fator bastante preponderante na (de)formação da criança pode estar aliado à massificação estonteante da midia, com toda a força de imagens, sons e mensagens repetitivas que valorizam o TER em detrimento do SER, atribuindo-Ihe um olhar reducionista, como se a criança fosse um estereótipo de adulto em miniatura

Trata-se de um processo propositalmente egoista e consumista, que visa apenas lucros financeiros, passando valores de erotização precoce, de violência e agressividade, reforçados, muitas vezes, pela própria familia, que também é vitima desse contágio massificante de senso comum não-reflexivo, transmitido, principalmente, por meio da TV. ${ }^{2}$

Não podemos deixar de mencionar que uma minoria de emissoras de TV preocupa-se com a qualidade de programas destinados ao público infantil. Contando-se os poucos existentes, estes ainda diminuem, em grande número, se

2 "Um alto percentual de crianças enfrenta-se com a televisão desde o nascimento, e é bastante comum o hábito de utilizá-la como 'babá eletrónica'. Na verdade, coloca-se o bebé desde o segundo mês de vida, diante do aparelho ligado, na crença de que assim ele se tranquilizará. Ele é colocado numa cadeirinha reclinada, o chamado 'bebé conforto', na qual permanece preso e precariamente sustentado. Não discutiremos o direito dos pais de assistir televisão. Tampouco menosprezaremos a situação social contemporánea, na qual o desmembramento da grande familia e sua reduçăo ao núcleo primário enfatizam o fenômeno da solidăo, como alguém que está em casa, que se lhe dé atençăo ou nåo. Consideramos que estas circunstâncias săo justificáveis para aqueles lares onde năo há crianças. Por outro lado, é conveniente que se reflita se é justo e saudável retirar a atençåo de uma criança para dedicá-la ao programa de televisáo... Na verdade, apenas um pequeno número de famílias tem uma noçăo clara sobre o prejuizo que este hábito ocasiona no início da infáncia, assim como săo poucos os que percebem a influência nefasta exercida pelos programas de violéncia, ou as que relacionam a isso as dificuldades apresentadas por seus filhos... (SOIFER, 1991: pp.11. 13) 
nos detivermos a analisar a qualidade de sua apresentação para uma verdadeira formação integral da criança.

A este respeito, FUSARI (1985) realça a influência exercida pelo desenho animado, que a criança vê na televisão, na construção de valores ou antivalores de vida:

"Um esboço do objeto de observação e estudo - a criança convivendo com a TV, o desenho animado e o adulto

- Quantos anos você tem?

- Seis

- O que você gosta mais de ver na televisão?

- Desenho

- E o que mais que você gosta?

- Desenho e filme

- Qual é o desenho que você gosta mais de ver?

- Pica-pau

- E qual outro?

- Ah...Popeye

- E por que você gosta mais do Pica-pau?

- Ah...porque eu acho mais bom Pica-pau?

- É? E que é que esse Pica-pau fica fazendo, me conta? Como é que é esse

- Ah, ele pica o pau.

- E o que mais que ele faz?

- Ah... Ele estoura bomba. (...)

- Qual é o outro desenho que você gosta?

- Popeye.

- Por que você gosta do Popeye?

- Por causa que ele bate no homem.(...)" (p.15)

Por meio das colocações anteriores, percebemos que a criança precisa de uma acurada atenção do adulto, no sentido de levá-la a refletir sobre sua própria vida, oferecendo-lhe oportunidades construtivas e positivas, na vivência de valores humanos básicos para a sua formação integral como: o respeito, a ética, a amizade, a cooperação, a concórdia, a bondade, a lealdade, entre outros, auxiliando-a a lidar com as situaçōes de conflito na resolução dos mais diversos tipos de problemas.

A escola precisa, como instituição de formação, buscar ser um lugar de prazer para a criança, um espaço onde ela possa elaborar o seu mundo interior, estruturando-se de forma equilibrada em sintonia com as situaçōes exteriores que a cercam no dia-a-dia. 
Na apresentação do livro de MARCELINO (1997): Pedagogia da Animação, Rubem Alves faz colocações significativas no que se refere ao prazer e ao mundo interior dos seres humanos e ao papel da escola neste sentido:

"Recuperar a Alma é sair deste abismo de alienação: perceber o seu direito ao Prazer. Porque é para isto que tudo se faz neste mundo, inclusive as revoluções(...)

$\mathrm{Na}$ verdade nossas práticas educacionais, em nome dos ideais do progresso e mesmo de revolução, têm significado uma expansão ilimitada de conhecimento acerca do mundo, e uma brutal repressão da alma. Poderiamos então repetir a velha pergunta dos textos sagrados: 'De que nos vale ganhar o mundo inteiro se perdemos a nossa alma?' (...)

Redescobrir o lugar do sonho, reencontrar as origens da Alma. Esta seria a tarefa educativa fundamental, preliminar a tudo o mais que se possa fazer. Para que o poder e a competência não sejam possuidos por demônios (...)

Assim, quando Nelson Marcelino fala sobre uma 'pedagogia da animação' ele está sugerindo que a educação tem de redescobrir suas origens na Alma (...) O texto de Nelson Marcelino é, assim, antes de mais nada, um desafio para se repensar os próprios fundamentos da educação." (pp. 12-6)

Como lugar de formaçāo, a tarefa básica da escola parece ser a de respeitar o universo da cultura da infância, proporcionado à criança tudo o que for preciso para que ela se sinta realmente feliz e completa no ambiente escolar. Para isto, há que se buscar múltiplos caminhos possiveis na consecução desta meta.

SNYDERS (1993) faz comentários indispensáveis a todos os envolvidos no processo educacional sobre a importância da alegria na escola como um fator determinante que ocasiona um acréscimo de vida, fazendo o indivíduo sentir-se prolongado, enquanto que a nāo-alegria leva à dispersão e à restrição:

"(...) Temos uma segunda razão para acreditar que o eterno problema da alegria na escola possa conhecer um progresso decisivo hoje. Durante séculos, a escola pôde subsistir proporcionando aos alunos pouquissima alegria no presente. Mas, hoje, muito mais jovens passam muito mais tempo na escola, não só todas as fases da infância como uma grande parte das fases da adolescência se desenvolvem no universo escolar. A adolescência escolarizada exerce uma influência sobre a infância, que está ciente de ter um longo periodo de aulas pela frente. Não se trata mais de um periodo breve no qual é possivel resignar-se com a ausência da alegria - provisoriamente." (p.35)

Nesse sentido, podemos pensar numa retomada da importância da Educação Infantil, como etapa basilar da formação, proporcionando às crianças a alegria de estar na escola, ou seja, de sentir o prazer do momento presente, construindo o desejo de continuar na escola no futuro.

Há que se pensar em estratégias consistentes para se edificar este caminho de alegria... e a Literatura, com certeza, apresenta grande oportunidade para trabalhar a cultura da infância, valorizando o seu universo lúdico e, ao mesmo tempo, conferindo-Ihe os Valores Humanos tão necessários para sua formação. 
É preciso resgatar o valor da Literatura para as crianças, discutir com elas sobre as atitudes das personagens das histórias, mediar questionamentos para que elas próprias cheguem à resolução de problemas como seres participantes, capazes de interagir e não simplesmente copiar modelos adultos, por influência da inversão de valores já mencionada anteriormente.

Dessa forma, para atingir o intento de 'formar caminhos para uma Educação em Valores Humanos', busquei colocar-me, pessoalmente, por meio de reflexōes e discussões relacionadas ao tema, servindo-me, para tal, da contribuição da Literatura, como uma indispensável e constante parceira, neste processo de investigação, enfocando as histórias e os diversos textos oriundos de escritores nacionais e internacionais, capazes de me auxiliar, com ilustrações elucidativas e oportunas, de forma a enriquecer a mostra de exemplos e sugestōes pertinentes à elaboração deste trabalho. 


\subsection{As memórias...raízes de toda história... \\ Minhas memórias de infância}

'Feliz aquele que consegue conhecer

as causas das coisas'

Virgilio

Considero minha infância como um momento mágico e muito feliz.

Recordo-me que queria muito ter um irmão ou irmã para me fazerem companhia, mas meus pais, por razões particulares, não puderam me atender nesse sentido; porém, este motivo não foi causador de mágoas ou tristezas, pois meus amigos, primos e vizinhos acabaram preenchendo minha vida de filha única, e digase de passagem, não mimada ou indevidamente atendida sem limites, como costuma caracterizar o jargão popular para os filhos únicos

Costumava brincar com bonecas, imitava minha mãe, usando suas roupas e calçados, incorporava personagens e profissionais de diferentes áreas, brincando de ser secretária... enrolando papel sulfite e depois desenrolando-o fazendo de conta que era máquina de escrever e de médica... furando com agulha papéis variados, criando picotes para fazer de conta que eram fichas para recorte de consulta para atendimento de pacientes. Aliás, já havia decidido ser médica pediatra, desde muito pequena, pois achava muito importante cuidar de crianças, mas um dia descobri que os médicos, tinham que fazer 'autópsia' em cadáveres e isso, depois que me foi explicado, fez-me desistir imediatamente deste ofício, pois diante deste quadro tinha absoluta certeza que acabaria não correspondendo às expectativas que em mim seriam depositadas para exercer tal ofício... Como sempre gostei de brincar de escola, assumindo preferencialmente o papel de professora, acabei descobrindo que esta seria, na verdade, minha verdadeira profissão futura...

Por morar em apartamento, não possuia animais de estimação, salvo um casal de periquitos australianos batizados romanticamente como Romeu (com penas azuis, chamuscadas de preto e peito branco) e Julieta (com penas amarelas em tons claros e escuros), que chegaram a constituir família, dando-me o prazer de ver nascer seus descendentes, sob nossa observação. Romeu era de temperamento mais dócil e calmo, costumava bebericar gotas de água quando colocava meu dedo indicador por entre as grades da gaiola para acariciá-lo. Julieta, ao contrário era arredia e jamais aceitava meu carinho, por mais que me esforçasse; no entanto, o que mais me admirava era ver como se transformava em meiga e carinhosa ao receber gotinhas de água do bico de Romeu. Coisas do amor...

Lembro-me, até hoje, como fiquei surpresa ao ver que a própria Julieta, quando do nascimento de seus filhotes, jogava alguns ovinhos para fora do ninho, talvez por instinto de pressentir uma má formação, quem sabe? Quando os filhotes 
nasceram, senti-me também responsável por eles e adorava ver Julieta levar comida e encher seus pequeninos bicos. Romeu, ao contrário, nem podia chegar perto do ninho: coisas de fêmea superprotetora..

Um dia, chorei compulsivamente, após ter aberto a tampa do ninho para ver os filhotes do casal romântico e um deles acabou fugindo. Nunca me perdoei por esta 'arte' e jamais soubemos daquele filhote depois disso. O que mais me afligia era pensar na possibilidade de ele ter sido comido por um gato. Chorei muito, tambem, quando, depois de alguns anos de convivio (primeiro Julieta adoeceu, sua barriga ficou grande e disforme e depois Romeu, de modo inesperado, talvez por conta da idade), morreram e me deixaram muita saudade..

$\mathrm{Na}$ casa de minha avó materna, localizada no bairro do Macuco em Santos/SP - pela vantagem oferecida por um espaço amplo, permeado com extenso quintal, decorado com árvores e flores $e$, ainda, com vasta calçada rodeando o sobrado construido na frente e um chalé, que foi a primeira construção feita no terreno, que se estendia quase de uma rua a outra - podia satisfazer os desejos de toda criança: andar de bicicleta, colecionar joaninhas colhidas no quintal e guardadas em caixas de fósforo, até que por conta própria acabavam fugindo... retirar pétalas de margarida e fazer de conta que eram unhas postiças, brincar de pega-pega, esconde-esconde, roda etc. Brincadeiras que, ao final do dia, acabavam deixando-me exausta em demasia, como reflexo de um querer fazer de tudo um pouco naqueles dias de magia que só a infância é capaz de nos proporcionar. O resultado: quando retornava à nossa casa, em São Vicente, chegava quase sem forças para subir as escadas que me levariam de volta ao lar, ,. E uma lembrança bastante acalentadora que guardo destes momentos de excessivo cansaço è que meu pai sempre se dispunha a me levar no colo até o terceiro andar onde ficava o nosso apartamento. Estes momentos de carinho não verbalizado, mas significativamente demonstrado, tiveram muito valor para mim e, até hoje, sinto-me muito feliz ao recordá-los.

Outra lembrança marcante destes momentos na casa de minha avó materna era de quando eu ficava penteando seus cabelos brancos como se fosse sua cabeleireira e também da paciência que tinha comigo quando queria fazer de conta que era sua professora. Lembro-me que consegui ensiná-la a escrever o seu próprio nome e da alegria que demonstrou ao escrever em um pedaço de papel de embrulho, pela primeira vez em sua vida, por volta dos setenta e sete anos: 'Carmen'... Deste dia em diante, lembro-me que quando ia receber no banco a pensão de meu avô, já falecido, não precisou mais colocar o polegar para registrar a sua marca/assinatura, pois já escrevia, mesmo com dificuldade, o seu próprio nome. Depois de tantos anos, fico pensando que talvez esta memória da sensação de contentamento e de felicidade, minha e dela, possa ter desencadeado ou ter me certificado sobre a paixão de ensinar e aprender, de sentir isso em mim e no outro... Este fato foi muito importante para mim, pois mesmo com minhas próprias dúvidas e dificuldades, já que, apesar de ainda não ter ingressado na escola, e de também possuir inseguranças em relação à escrita, consegui dividir com minha avó o pouco que sabia e com isso saímos juntas de uma situação de construção em parceria...

Tive muitos tios e primos, o que deixava nosso Natal e Ano Novo com um clima feliz e de alto astral, lembro-me que não viamos a hora de abrir os 
presentes... e quanto à ceia o que mais esperávamos era o pernil, assado no forno da padaria perto de onde morava, após ter sido preparado por minha mãe - que já era oficialmente designada, a cada ano, para esta tarefa - e a Tubaína (refrigerante muito apreciado pelas crianças naquela época)...

A casa de minha avó paterna fica em São Paulo, na Vila Formosa. Pela distância, não iamos lá com muita freqüência. Costumávamos, eu e meus pais, visitar minha avó, aos domingos, juntamente com meus tios e primos, a fim de reunir a família toda. Lembro-me da festa que eu e meus dois primos faziamos com os diversos cachorros que minha avó Rosália possuia e, principalmente da rede em nos deliciávamos em balançar bem alto, deitando e fazendo força os três juntos, até o dia em que fizemos a arte de despregá-la da parede pelo excesso de peso, fazendo com que minha avó corresse atrás de nós três brigando muito e querendo ajustar as contas... Percebiamos que ela ficava brava com nossas peraltices, mas sabiamos, também, que estávamos longe de ser santinhos, por isso gostávamos muito dela e de seu jeito autêntico de ser. Passávamos o dia lá, brincávamos o dia inteiro e minha avó fazia questão de nos levar para conversar com a vizinhança dizendo: - 'o meu povo chegou'...era sempre a mesma frase e dita com a mesma entonação de seu sotaque alagoano. Quando vínhamos embora, minha avó ficava sempre muito triste querendo saber quando voltariamos novamente. Sentia que mesmo não falando, ela se mostrava muito só, já que meu avô paterno era falecido. Colhia couve, temperos e alface fresquinha de sua horta para levarmos para casa. Era um ritual delicioso em todos os sentidos

A entrada para a escola foi muito esperada. Não via a hora de começar a 'estudar'. Infelizmente, perto de onde morava não havia nenhuma pré-escola e tive que esperar até completar sete anos para ingressar no meio escolar - meu grande sonho. Mas, em casa, lembro-me que desenhava e gostava de perguntar sobre as letras. Um dia. copiei o nome do televisor que tinhamos na sala: PHILLIPS - e minha mãe ficou admirada, pois não esperava por isso. Sabia escrever meu nome antes de ingressar na primeira série e achava isso muito importante, afinal era a minha marca... Um outro interesse era contar: ficava na janela do apartamento onde morava, contando quantos carros passavam na rua e dizendo para minha mãe quantos fuscas, ônibus e outros tipos de carro passavam por lá.

Mas, a paixão de ler e escrever era a maior de todas...Costumava ganhar livros de histórias e adorava inventar a narrativa antes de saber ler. Meu programa favorito de TV era Vila Sésamo, pois havia pessoas que falavam de histórias, cantavam e contavam fatos engraçados para as crianças.

Minha primeira professora chamava-se Daisy Pagan Lupinacci. Até hoje, lembro-me de seu rosto angelical, como se fosse uma fada saida das histórias que gostava de olhar nos livros: era meiga, tranqüila e carinhosa, tinha uma fala mansa e calma, deixava-me muito segura e sempre querendo voltar para a escola no dia seguinte. Seus olhos eram azuis e brilhantes e os cabelos loiros, finos e lisos, presos com um 'coque' delicadamente torneado na cabeça.

Conhecer D. Daisy foi a confirmação que tive sobre ser professora. Olhava para ela e pensava que queria ser uma professora tão boa quanto ela era, pois conseguia agradar a todas as crianças e nos ensinar muitas coisas importantes. 
Nas séries seguintes, $2^{a}, 3^{a}$ e $4^{a}$, do Ensino Fundamental, antigo primário, D. Marília Martins de Almeida assumiu o lugar de D. Daisy. No principio, lembro-me que fiquei muito triste, pois D. Marilia tinha a fama de ser a professora mais brava da escola. Isso me assustou bastante antes de conhecê-la; no entanto, depois percebi que ela era realmente séria e exigente, mas que, a seu modo, também conseguia ser importante para os seus alunos e ensinar o respeito, o companheirismo e a responsabilidade para todos nós.

Essas duas professoras, com certeza, tiveram uma participação de base em minha formação. Até hoje, consigo recordar-me de fatos ocorridos em nossas aulas de há mais de três décadas $e$, principalmente, dos livros de histórias que ganhava de presente de minhas inesqueciveis mestras, ao final de cada ano... aliás, ainda os conservo guardados comigo como exemplo do valor inestimável que possuem para mim.

O tempo, realmente, parece não existir para o registro da memória de aprendizagens e vivências significativas de nossa infância. Todos os fatos e situações registrados em nossas memórias, com certeza contribuíram, continuam contribuindo, e contribuirão sempre em sua (re)significação atemporal, para formação integral de nosso ser nos aspectos afetivos, sociais e cognitivos.

\subsection{As memórias de infância e a influência na formação do professor/educador}

'Profissões e vocações são como plantas.

os educadores são como as velhas árvores.

Possuem um nome, uma 'estória' a ser contada.

Habitam um mundo em que o vale

é a relação que os liga aos alunos,

sendo que cada aluno é uma entidade 'sui generis', portador de um nome e também de uma estória, sofrendo tristezas $\theta$ alimentando esperanças.

E a educação é algo para acontecer neste espaço invisivel e denso, que se estabelece a dois.

Espaço artesanal.'

Rubem Alves

Quando iniciei minha carreira de professora, após o término do curso de Magistério, já me sentia muito responsável por meus pequenos alunos. Procurava encontrar caminhos para favorecer a trajetória de seu desenvolvimento e sempre acreditei que o mundo da fantasia, transmitido no ouvir e contar histórias, representava um incentivo à leitura, fato indispensável para o desenvolvimento da reflexão, da interpretação e da expressão oral e gráfica, pois, para mim isso tinha 
ficado nitidamente registrado em minha memória, a partir de situações vivenciadas em minha infância.

Comprovei isso, no decorrer dos anos, através da experiência como professora de Língua Portuguesa, desde o Ensino Fundamental até à Universidade, sentindo a defasagem que existe no exercício da leitura e escrita, pois os alunos demonstram sérias dificuldades no momento de se expressarem oral e graficamente, sendo que a maioria não consegue associar a leitura e a escrita como práticas prazerosas, mas apenas como compromissos escolares que precisam ser cumpridos, já que são, na maioria das vezes, cobrados por meio de notas, conceito, avaliações ou qualquer outro tipo de teste de 'conhecimento'...

Acredito que a Educação Infantil representa o caminho inicial para o despertar da paixão pela literatura. Esse fato desencadeou em minha prática, enquanto de professora de Educação Infantil, algumas alternativas de trabalho, capazes de aproximar as crianças do universo sedutor das histórias e, ao mesmo tempo, proporcionar-lhes oportunidades de vivências que pudessem auxiliá-las em sua vida escolar e também fora dela.

Nesse sentido, tenho constatado que a vivência dos Valores Humanos, apresentados nas histórias infantis, propiciam às crianças, por meio das personagens, mensagens e reflexões que funcionam como verdadeiros veículos de aprendizagem de vida, mesmo que aparentemente as crianças não se dêem conta disso, já que os momentos de ouvir e contar história são carregados de emoção e prazer, desconectados de uma imposição de informação sistematizada ou rígida.

No trabalho com as crianças, lembro-me que, observando a importância das histórias e o grande interesse das crianças, demonstrado pelas mesmas, escrevi algumas histórias e peças teatrais para as crianças vivenciarem e participarem como personagens e também os professores (Ex:. O coelhinho beijador, O Natal dos sentimentos...), o que aproximou bastante as pessoas da escola e estreitou as relaçōes entre todos os parceiros

Parece que ninguém resiste à reflexão sobre a mensagem que as histórias apresentam e isso é um meio rico de trabalharmos as questões de formação e informação no convivio escolar e, também, em outros ambientes partilhados pelas crianças e também pelos educadores.

Acredito que recordar a infância é um exercicio bastante eficaz que deve ser oferecido, a todos os educadores, principalmente aos de Educação Infantil, pois revivendo as situações que nos foram importantíssimas enquanto éramos crianças, temos mais clara a idéia de resgatar as histórias, as brincadeiras e todo o universo da fantasia que nos auxiliou, ou não (por faltas ou falhas que nos passaram), em nosso desenvolvimento integral.

Dessa forma, refletindo sobre os fatos positivos, que nós educadores vivenciamos, podemos tentar continuar aprimorando-os em sua apresentação às nossas crianças. Quanto aos fatos negativos, precisamos estar alertas para não reproduzi-los às crianças, tentar suprir possiveis defasagens ou dificuldades que tivemos e nos observar, a cada momento, para não repetirmos o jargão, colocado em sentido pejorativo, de que a história se repete, já que, nesse sentido, nossas crianças não são responsáveis por nossas dificuldades e é responsabilidade do 
professor ter isso muito claro em sua prática, procurando oferecer às crianças o que há de melhor para o seu desenvolvimento.

Esse exercício de transformação continua exige do professor/educador muito esforço e muita humildade, pois precisa perceber-se, também, em formação e constante estado de revisão e reavaliação de sua prática cotidiana. Para Rubem Alves (1985), por meio de uma colocação metafórica, o professor deve esforçar-se para ser 'jequitibá' (verdadeiro educador, contextualizador, mediador) - árvore forte, que se aprimora e se perpetua no tempo e no espaço - , evitando fugir do senso comum... de ser simplesmente 'eucalipto' (apenas professor, por decorrência de sua formação ou graduação) - árvore que se reproduz em série sem o padrão de qualidade apresentado pelo jequitibá...

Tentar não esquecer a criança que foi um dia - recordando-se detalhadamente das habilidades e, também, das dificuldades vivenciadas - e que ainda mora em seu interior, pode ser uma boa estratégia para que o professor, verdadeiro educador, consiga esforçar-se, a cada dia, para alcançar os parâmetros qualitativos de sua atuação.

Nesse aspecto, a memória constitui-se como uma aliada do professor/educador na (re)construção de seu ser e de seu saber.

\subsection{As Memórias de Professores/Educadores}

Coraçåo
Lembrança, quanta lembrança
dos tempos que lá se vão!
Minha vida de criança. minha bolha de sabåo!
Infáncia que sorte cega,
que ventania cruel. que enxurrada te carrega
meu barquinho de papel!
Como vais, como te apartas,
e que sozinho estou!
- O meu castelo de cartas,
quem foi que te derrubou?
Tudo muda, tudo passa
neste mundo de ilusão:
vai para o céu a tumaça
fica na terra o carvåo
Mas sempre, sem que te iludas
cantando no mesmo tom.
só tu coração nåo mudas.
Guilherme de Almeida

${ }^{3}$ Conservou-se a originalidade quanto à grafia do texto, a fim de preservar a autenticidade da escrita, na época em que o mesmo foi redigido e compilado, no livro "Saudade" de Tales de Andrade, em 1954 , quando do $49^{\circ}$ ano comemorativo do lançamento da $1^{\text {a }}$ edição. 
Considerando a infância como o marco de construção do alicerce de desenvolvimento integral do ser, e uma fase de grandes possibilidades para o estabelecimento das vivências dos valores humanos, apresentaremos, aqui, o depoimento de alguns educadores que, por meio da memória, reportaram-se à infância, ilustrando a relação de suas experiências, vivenciadas no passado como crianças, e suas experiências e pontos de vista atuais como educadores.

Para conseguir tal intento, foram elaboradas questões diretamente ligadas à sondagem, feita por meio de entrevista, a alguns dos educadores, sobre suas memórias de infância, relacionando, também, o papel das histórias ouvidas e lidas por eles quando crianças, já que o objetivo deste trabalho almeja explorar a Literatura e os Valores Humanos vivenciados nas mesmas.

As entrevistas foram realizadas com professores de Educação Infantil, que trabalham com crianças de 2 a 6 anos de idade, em escolas públicas (municipais) e particulares das cidades de Santos e São Vicente (litoral do estado de São Paulo).

Os depoimentos foram registrados conforme as colocações dos professores, respeitando-se a grafia original das palavras e mantendo incógnitos os nomes por uma questão de ética e discrição. Quanto à idade e à escolarização, foram mencionadas, a fim de se tentar estabelecer uma reflexão sobre as possibilidades de memória, a experiência de vida e profissional, além de se tentar verificar uma relação de valores já arraigados, ou não, através do decorrer dos anos vivenciados dentro e fora do contexto escolar.

A seleção dessa pequena mostra ilustrativa foi feita a partir de uma coleta direcionada ao objetivo do trabalho, buscando exemplificar, através de alguns depoimentos de professores, o fato de acreditarem na Literatura como um veículo importante para a aprendizagem e desenvolvimento da criança.

\subsection{Sondagem sobre as memórias de infância de professores/educadores de Educação Infantil das redes de ensino público (municipal) e particular}

'A memória, quando desenha um quadro já vivido, sempre o faz de maneira diferente.

Diferente porque já impregnado por um crivo, por uma seleção que - se não afiança a precisão da objetividade garante a riqueza da subjetividade, que igualmente é fidedigna e indicadora de validez...'

Gabriel A. Junqueira Filho 


\section{Parte I}

\section{$\underline{1^{a} \text { questão-Qual é a sua opinião sobre as memórias de infância? Por quê? }}$}

A- (29 anos, nivel universitário completo, professora de escola de Ed. Infantil municipal)

Acredito que os momentos vividos nos trazem boas ou más recordações, contribuem em parte para o adulto em que nos tornamos e servem de base para repetirmos ou evitarmos situações/sentimentos vivenciados com nossas crianças.

B- (34 anos, nível universitário completo, professora de escola de Ed. Infantil municipal)

As memórias infantis são carregadas para a vida adulta. Os fatos positivos fortalecem a formação de personalidade do adulto e ele pautará a vida em valores socialmente aceitáveis. Os fatos negativos podem deixar marcas, frustrações e até incentivar a rebeldia e violência futuras.

C- (40 anos, nivel universitário completo, professora de escola de Ed. Infantil municipal)

Nossa infância é um período mágico e de fundamental importância para o nosso amadurecimento e crescimento interior.

D- (24 anos, ensino médio completo, professora de escola de Ed. Infantil particular)

São essas lembranças que muitas das vezes nos faz pensar em como agir com nossos alunos e filhos, pois tudo é registrado e dificilmente esquecido.

E- (25 anos, nivel universitário completo, professora de escola de Ed. Infantil particular)

É dai que parte a formação do indivíduo para toda a sua vida.

F- (27 anos, nível universitário em andamento, professora de escola de Ed. Infantil particular)

Considero bastante importante as memórias de infância, porque é muito bom relembrar desta fase da vida, pois acredito ser a melhor, quando somos crianças temos muitos sonhos e vivemos com mais intensidade as coisas boas da vida.

$\underline{2^{a}}$ questão- Quais são suas memórias de infância mais marcantes em relacăo a: 


\section{2. a-Sua casa, sua familia (pais, irmãos etc...), amigos, vizinhos.}

A- Recordo-me de brincar com uma de minhas irmãs, de jogar bola no quintal e correr na praia com meu pai, da minha mãe me chamando com carinho para que eu tomasse café, de uma vizinha que ficava comigo enquanto minha mãe trabalhava, de brincar com outras crianças respeitando a orientação de minha mãe para que ficasse no quintal, de visitar parentes nos finais de semana etc.

B- A casa e familia são memórias muito felizes de brincadeiras, festas de aniversário, Natais alegres e muita união e respeito. Aquele tempo em que o olhar dos pais declarava o que estava acontecendo. Os vizinhos e amigos: marcas de infância cercada de brincadeiras, jogos, cumplicidade e muita inocência.

C- Em relação a minha casa, lembro-me do rico espaço que tínhamos para brincar, embora pudéssemos brincar também livremente na rua e calçadas. Jogos com bola, pega-pega, esconde-esconde, cantigas de roda, ainda hoje, tenho presente em minha memória. Quanto à família, tenho saudades das viagens de férias, das reuniões familiares em diferentes comemorações.

D- Na minha infância foi tudo muito gostoso, morei numa casa linda e enorme, meus pais eram muito legais e participaram bastante de minha infância, meus irmãos, como é até hoje, são meus melhores amigos em tudo, tive muitos amiguinhos e meus vizinhos eram maravilhosos, viviam correndo atrás de mim, pois eu era muito peralta.

E- Em casa uma familia muito unida, fazendo sempre todas as refeições com todos à mesa, conversando; os nossos passeios, etc. Eu brincando com meu irmão de carrinho, de bicicleta. Com meus amigos e vizinhos, jogando bola na rua, queimada, rouba bandeira, pega-pega, amarelinha, etc.

F- Recordo-me da minha casa em dias de festa como o Natal, reuniamos a familia e os vizinhos para a distribuição dos presentes na brincadeira do amigo secreto. Outro dia muito gostoso era a festa junina, todos os vizinhos reunidos, dançávamos quadrilha, tinha fogueira e muita comida gostosa.

\section{2.b - Seus animais de estimacão.}

A- Lembro-me de dois cachorros, sendo que com um deles, chamado "Fiel", acompanhei fases do crescimento e brinquei bastante. 
B- Só tive um cachorro, mas já éramos adultos. Tivemos pena de morara em apartamento e não ter espaço para o bichinho crescer. Ele foi dado a uma família com três crianças que morava em casa. estimação.

C- Embora tivéssemos espaço em casa, não possuiamos animais de

D- Tive vários cachorros, pássaros e coelhos e uma tartaruga e o legal é que lembro o nome de vários deles.

Uma coisa que me marcou muito foi quando perdi o meu $1^{\circ}$ coelhinho, sofri muito e até fiquei doente, eu tinha 7 anos e não me esqueço nunca disso, depois eu ganhei outros coelhos, mais o $1^{\circ}$ se tornou inequecivel.

E- Tive 3 cachorros, mas o $1^{\circ}$ era o que eu mais gostava, pois ele brincava, corria comigo e era muito carinhoso.

F- Sempre gostei muito de gato e o meu primeiro animal de estimação foi uma gatinha chamada Lilica, éramos amigas inseparáveis, ela teve muitos filhotes, um deles que ficou bastante tempo conosco foi o Nil. Outros animais: cachorro Chang, uma tartaruguinha e uma porquinha da Índia chamada Gabi.

\section{2.c - Suas brincadeiras e brinquedos preferidos.}

A- Gostava de brincar com bonecas, inclusive as bonecas de papel, com bola, de amarelinha, de bambolê, de pular corda, de mãe da rua, de escolinha, de esconde-esconde, da brincadeira do elástico.

B- Brincava de tudo: boneca, casinha, comidinha, jogava com os irmãos, fazia pipa, bolinha de gude, bicicleta, fantasias ...

C- As brincadeiras de rua como: queimada, esconde-esconde, pega-pega... Em relação aos brinquedos, não havia muitos brinquedos industrializados. Lembrome de bolas, bicicletas e algumas bonecas que tínhamos para brincar.

D- Eu brincava muito de caracol, fita, mãe da rua, gosta de quem, pulacorda, pega-pega, esconde-esconde, e tantas outras.

E- Queimada, duro ou mole, esconde-esconde, vôlei, rouba bandeira, alerta, reizinho mandou, mês, stop, bonecas, ursinhos, carrinhos, bicicleta, etc. 
F- Brincadeiras: amarelinha, pular corda, esconde-esconde, pega-pega, mês, casinha, queimada, barra amnteiga, fita, passa, passa três vezes, boca de forno.

Brinquedos: bonecas, patins, bambolê, bonecas de papel que trocava roupinhas, pata de cavalo (brinquedo feito de latas)

\section{2.d - Seu(s) lugar(es) favorito(s) para passear ou visitar.}

A- Gostava de ir à praia e de visitar uma tia.

B- Meus avós levavam para passear no Orquidário, Aquário, praia, Museu de Pesca, morro e na lagoa da Saudade. Andávamos de ônibus até os lugares e brincávamos nestes espaços. Meus pais trabalhavam e os avós promoviam estes momentos diariamente.

C- Como morávamos no interior de São Paulo, era uma festa quando vinhamos passear no litoral. Fora isso, costumávamos organizar pic-nic e passeios nos rios próximos a nossa cidade.

D- No sítio dos meus avôs, na cidade da criança, no Playcenter, no zoológico e viajar para Juquiá

E- Horto (atual Jardim Botânico)

F- Orquidário, praia, Biquinha e parque.

2.e Seu primeiro contato com a escola: seu (sua) primeiro (a) professor (a). seus amigos, suas emocões e sensacões inesqueciveis (aqradáveis ou não).

A- Não tenho lembranças muito claras destes momentos. Gostava da professora, dos colegas e de freqüentar a escola. Lembro-me do nome de um amiguinho, mas não tenho certeza se o conheci no meu primeiro ano na escola e de algumas situações gostosas e engraçadas vividas.

B- O primeiro contato foi ótimo para mim e ainda lembro do dia. A professora recebia as crianças no portão da escola e ficávamos sentados ao seu lado. Minha mãe chorou porque eu corri para a escola e não lembrei dela. O espaço era grande e as pessoas eram gentis e amigas. 
C- Foi muito feliz! Às vezes quando me pego lembrando da minha vida escolar parece que até sinto o "cheiro" dos lugares em que convivia com meus amigos e professores.

$D$ - Eu tinha 5 anos. Foi no parque Clemente Ferreira, minha primeira professora foi a tia Ana Maria eu a adorava ela foi uma pessoa muito especial, pois eu chorei muito no primeiro dia de aula, mais ela me conquistou com o seu carinho, tive vários amoguinhos mais a Aninha, a Cintia e o Leo foram os melhores.

E- Entrei no pré, chorava todo dia, pois queria minha mãe. Depois fiz amizade $\mathrm{c} /$ os alunos e ficou tudo bem.

F- Recordo-me que tinha muita vontade de ir a escola, portanto meu primeiro contato foi muito bom, eu tinha seis anos quando ingressei na pré-escola. Lembro-me de músicas que cantávamos, a bandinha que organizamos no final de ano e o teatro que apresentamos: A cigarra e a formiga. Minha professora da préescola, eu me lembro mais por causa das fotos, a da $1^{a}$ série tenho vagamente sua imagem na memória. Eu canto com meus alunos uma música que aprendi com minha professora Maria José $\left(1^{a}\right.$ série $)$.

\section{Parte II}

$1^{a}$ questão- Alquém costumava contar-Ihe histórias em sua infância? Quem? Escreva suas lembranças sobre isso.

A-Sim. Lembro-me de minha mãe contando histórias (sem livros), de minha avó lendo "pequenas histórias" de seus livros (usados para sua alfabetização), de uma tia lendo pequenos livros comprados nas bancas de jornais.

B- Meu avô materno comprava livros de contos infantis: Irmãos Grimm, Perrault, Walt Disney, de clássicos e contava histórias quando nós voltávamos da escola. Variava de duas ou três vezes na semana. Chegávamos e sentávamos na sala para ver os desenhos e ele contar as histórias. Era um momento mágico.

C- Sim. Lembro-me que em um Natal minha irmã mais velha ganhou um livro de contos de fadas. Era uma felicidade imensa quando ela lia para nós os contos de fadas. Minha mãe também contava histórias de sua infância (Saci, Mula sem cabeça) que adorávamos ouvir!

D- Minha mãe e minha vó Analia.

Bom, a mãe contava mais histórias de livros e a vó era um show, contava histórias que ela inventava e conto para o Lucas (filho). 
E- Minha mãe. Não me lembro muito bem.

F- Sempre fui muito difícil para comer, por isso, minha mãe me contava muitas histórias que ela mesma inventava além dos clássicos da literatura.

\section{$\underline{2^{a}}$ questão- Quais suas histórias favoritas (ouvidas ou lidas) na infância?}

A- Muitas histórias desde as ouvidas nos disquinhos: Pedro e o lobo, 0 macaco e a velha, $S$ formiguinha e a neve, Os três porquinhos e os clássicos: Cinderela, Branca de neve, Galinha dos ovos de ouro, Pinóquio, Chapeuzinho vermelho e todas as obras de Monteiro Lobato.

B- Carlota, a menina diferente, A galinha ruiva e Os três porquinhos.

C- Os clássicos: A bela adormecida, Chapeuzinho vermelho, Pinóquio e as que minha mãe contava que na maioria das vezes eram de sua autoria para nos distrair. Era ótimo!!! Ah! Não posso esquecer do fabuloso Robson Crusoé.

$D$ - Os três porquinhos, Chapeuzinho vermelho, João e Maria, Na casa de Tom. Todas as histórias contadas por minha vovó.

E- Os três porquinhos, Branca de neve.

F- O menino maluquinho, Sítio do pica-pau amarelo, A grande fuga, O porquinho, Chapeuzinho vermelho, O três porquinhos. Gostava muito de ler gibi da Mônica, Luluzinha e da Bolota.

2.a - Você considera que estas histórias tiveram alquma influência em sua formação? Por quê?

A- Considero que as situações vivenciadas (atenção e hábitos de leitura) influenciaram emocional e moralmente porque permitiram momentos de maior aproximação com os familiares, as histórias eram explicadas e mexiam com a imaginação.

B- Sim. Acredito que as histórias incentivam o vocabulário, a criatividade e a imaginação. Toda história infantil tem uma mensagem que precisamos descobrir e ninguém pode viver como Cinderela esperando um príncipe, mas esta idéia quando criança é muito legal. Até pensar em castelos e carruagens! 
C-Sim. Acredito que despertaram em mim o interesse pela leitura.

$D$ - Acho que sim, porque eu lembro também que sempre depois das hsitórias, a minha mãe falava que tinha que tomar alguns cuidados e ter sempre respeito pela opinião dos outros e outros fatos. e do carácter

E- Acredito que sim, principalmente no que diz respeito à formação da moral

F- Sim, porque na escola gostava muito de fazer redação e uma vez, até ganhei um concurso da melhor redação. Além disso as histórias despertaram o gosto pela leitura, eu admirava tanto ler e escrever histórias, que quando alguém me perguntava o que eu queria ser quando crescesse, logo respondia: - Quero ser escritora

2.b- Em sua opinião, as histórias infantis são importantes para o desenvolvimento da criança? Por quê?

A- Sim. Acredito na importância das histórias pelos motivos citados na resposta anterior. Elas podem ajudar na formação e também informar as crianças de maneira interessante e agradável.

B- A história infantil é muito importante pois a criança vive a fantasia e o sonho. E depois, em suas narrativas, ela coloca fatos da história ouvida com a sua própria história. Começa a conhecer a realidade na comparação entre os fatos e o principal, amplia o vocabulário.

C- Sem dúvida, quando as crianças estão ouvindo histórias, elas se transportam para um mundo mágico, onde as personagens tomam forma e a criatividade não tem limite.

D- Claro, só acho uma pena que a maioria das pessoas não dão tanta importância as histórias infantis. Tem pessoas que não tem tempo, paciência e vontade de contar uma história para seu filho. Eu procuro sempre contar histórias para as minhas crianças, onde elas possam participar.

E- Com certeza! Porque através das histórias a criança viaja num mundo de sonhos e magia e cria um conhecimento amplo, que lhe ajuda a dar hipóteses para resolver situações que se não tivesse essa vivência, não conseguiria. 
F- Sim, porque estimulam a criatividade, o gosto pela leitura e consequentemente pela escrita. Muitas historias ajudam transmitir valores importantes e muitas vezes a resolver problemas emocionais e psicológicos. As histórias são importantes para trabalhar a linguagem oral.

\section{2.c - Você costuma contar histórias para os seus alunos? Com que} freqüência?

A- Sim. Não sei precisar a freqüência, envolvo as histórias geralmente com os objetivos a serem alcançados

B- Tenho o hábito de contar histórias uma vez por semana. Criando um clima especial na biblioteca, com livros, mostrando figuras, mudando a voz de acordo com a fala das personagens. Fiz o curso de contador de histórias e uso muito as técnicas que aprendi.

C- Sim, a roda da leitura faz parte da rotina diária do nosso grupo, como também o cantinho da leitura está sempre aberto ao término de uma atividade. Meus alunos têm liberdade de manuseá-los à vontade e periodicamente os livros são trocados para que continuem despertando interesse.

D- Costumo, quase todos os dias mesmo porque eles pedem, nós temos um horário especial para isso.

E- Sim. Todos os dias antes do início da aula. E quando por qualquer motivo, esqueço de contar eles me cobram. É um momento desejado por todos, ficam atentos a cada detalhe, o silêncio é absoluto e quando a história termina eles pedem para repeti-la e querem manusear o livro.

F- Sim, duas ou tres vezes por semana, além das atividades onde eles próprios elaboram a história (história coletiva, descrição de cenas ou figuras, montar histórias com recortes de revistas...).

\section{2.d-Que tipo de histórias seus alunos apreciam? Por que você acha isso?}

A- Acho que os alunos, em geral, apreciam as histórias porque elas mexem com a imaginação. Se divertem com as passagens engraçadas, mas acredito que cada criança tem sua preferência porque livremente escolhem pelo desenho e fantasia que envolve ou pelo paralelo que envolve realidade/fantasia.

B- Gostam de histórias com final feliz e gostam de histórias de "terror". Às vezes, criamos a história coletiva com castelos assombrados, fantasmas, monstros 
$e$, outras vezes, com lugares lindos, castelos brilhantes, principes, cavalos com asas, nuvens mágicas, flores, pássaros etc. Acho que as crianças gostam de "viver" a história com medo, alegria, sustos.

C- Gostam de suspense, rimas e os clássicos como: Os três porquinhos, Chapeuzinho vermelho e as que falam de principes e princesas. Acho isso porque quando peço para eles escolher a história do dia são sempre estas as solicitadas, embora eu apresente sempre novos títulos para eles.

$D$ - Eles preferem histórias que envolvam os fantoches, como personagens e alguns tem um pouco de mêdo, mais constantemente a bruxa tem que aparecer nas histórias, eles pedem muito pra bruxa aparecer, amim como a fada também.

E- Todo o tipo de história. Tenho trabalho com contos de fada, fábulas, lendas, tirinhas de gibi.

F- Em geral eles gostam de todas as histórias que são contadas, dificilmente acontece de não gostarem. As histórias, que mais apreciam são as que possuem animais, porque sempre pedem para que eu conte novamente.

\section{2.e - Em sua opinião, atualmente, o contato das crianças com as histórias} infantis é suficiente? Por quê?

A- Não. Socialmente não percebo a valorização dos livros infantis. As crianças acabam assistindo muito a televisão e pedindo brinquedos que "conhecem" através dela e que geralmente não envolvem os adultos (que "sempre" estão ocupados) e a escola é que favorece em alguns momentos este contato.

B- Não. As crianças têm pouco contato porque a família não compra livros, não lê para elas, prefere deixar vendo televisão. A cultura dos livros na cidade ainda é carente, há poucas bibliotecas para visita e os alunos não são incentivados a consultá-las.

C- Não, infelizmente devido a televisão, computadores e videogames, acredito que a literatura infantil está ficando um pouco de lado no periodo em que ela está em casa, pois na escola ela tem maior contato com os livros infantis.

D- Eu acho que depende de cada familia e de cada escola. Aqui na escola eu tenho cereteza que elas tem bastante contato com livros de histórias infantis. 
E- Acho que poderia ser maior, pois a história infantil mostra a moral que hoje tanto está faltando a nossos jovens, que justamente por falta de leitura cometem tantos erros hoje.

F- Não, porque muitas vezes as mães não costumam contar histórias para as crianças e infelizmente a televisão e o vídeogame ocuparam o espaço das histórias infantis

\section{2.f- O que pode ser feito para aproximar mais as crianças da literatura infantil?}

A- Projetos que envolvam as escolas (professores, pais e alunos) fazendo a aproximação e quem sabe se pensar (inicialmente nas televisões regionais) em pessoas contando histórias e em propagandas estimulando a leitura.

B- Acredito que o grande canal de aproximação é a escola e principalmente a pré-escola. Quando a criança começa a ter um contato especializado com os livros, a descobrir a palavra, a escrita, a ler imagem e interpretar as cenas, a dramatizar as histórias que o professor conta na escola fundamental o trabalho se intensifica com o uso da literatura.

C- Os pais e responsáveis que têm contato direto com as crianças devem proporcionar o acesso ao livro infantil. Os livros devem ficar à disposição das crianças para que elas possam manuseá-los à vontade, sempre que desejarem.

D- Eu acho que o ideal é sempre contar histórias, pois incentiva bastante as crianças.

E- Um maior incentivo de professores e pais.

F- A escola pode organizar o cantinho da leitura, montar teatrinhos através das histórias lidas, combinar o dia do livro (a criança traz o livro que mais gosta para a professora contar a história ou a própria criança pode contar).

2.g-Você considera que, de modo geral, a educacão atual privilegia o contato das criancas com as histórias nas escolas de Educacão Infantil? Justifique sua resposta.

A- Não. Acontecem momentos que favorecem a aproximação da criança com os livros infantis, mas não há um privilégio.

B- A proposta da LDB 9394/96 é incentivar a leitura e proporcionar condições para isto, mas acho que os professores são pouco envolvidos. Nas escolas particulares a cobrança é maior e as professoras da educação infantil léem mais para os alunos e em algumas há espaço de biblioteca. Em outras escolas a 
preocupação é mostrar "folhinhas" para os pais. Os professores precisam ler mais também para se apropriar do hábito de leitura e passar para os alunos.

C- Sim, acredito que a maioria das escolas de Educação Infantil possui um acervo rico em literatura infantil, ao qual as crianças têm livre acesso, pois só o fato de manuseá-lo livremente, já estimula a criatividade e desperta o interesse pela leitura.

D- Depende da escola. Aqui nós temos a possibilidade de passar as histórias infantis com uma série de recursos, como fantoches, fantasias, cartazes e outros.

E- Acredito que sim, pois a educação nas escolas de educação infantil, estão voltadas justamente a isso, ou seja, às crianças por isso esse aspecto deve ser privilegiado.

F- Depende muito da proposta da escola, mas de modo geral, penso que as escolas não valorizam as histórias infantis, porque estão mais preocupadas em agradar os pais e assim enfatizam mais as lições: cadernos, livros, exercicios em folhas e quando sobra um "tempinho" pode ser contada uma história de maneira rápida.

\title{
1.5. Reflexão a partir dos comentários dos professores/educadores
}

\author{
'O senhor mire, veja... o mais \\ importante e bonito do mundo é isto: \\ que as pessoas não estão \\ sempre iguais, ainda não foram terminadas, \\ mas que elas vão sempre mudando \\ Afinam ou desfinam. \\ Verdade maior. ' \\ João Guimarães Rosa
}

Após verificação das respostas dos educadores de Educação Infantil, percebemos que as memórias de infância têm uma grande influência sobre as concepções de criança para a maioria dos entrevistados.

Aliás, as memórias representam passagens significativas de nossas vidas, na medida que registramos fatos e situações que vamos tecendo no decorrer da caminhada. Parece estarmos diante de uma grande colcha de retalhos que se vão, unindo, intercalando e se compõem, aos poucos, até que, finalmente, sentimos que 
uma parte da história se ergueu e que, com certeza, outras virão novamente, seguindo o trajeto da constituição, das partes, que se vão novamente integrando cumulativamente, construindo e tecendo novas memórias, novas colchas ... novas redes de significaçōes que juntamos, guardamos, reconstituímos e transformamos, aproveitando a aprendizagem delas provenientes na continuação do caminho.

Nesse sentido, o tecer de nossas memórias baseia-se na participação de outros significativos, de pessoas que acabam entrando no cenário de nossa história, contribuindo, cada qual a seu modo e dentro do seu papel, para formarmos o grande enredo de nossa história - nosso marco e registro de vida.

João Cabral de Melo Neto pode auxiliar-nos nessa discussão, ilustrando-a com um de seus renomados poemas:

\section{Tecendo a manhã}

" Um galo sozinho não tece uma manhã: ele precisará sempre de outros galos. De um que apanhe esse grito que ele e o lance a outro; e de outros galos que com muitos outros galos se cruzem os fios de sol de seus gritos de galo, para que a manhã, desde uma teia tênue, se vá tecendo entre todos os galos.

$E$ se encorpando em tela, entre todos, se erguendo tenda, onde entrem todos, se entretendo para todos no toldo (a manhã) que plana livre de armação.

A manhã, toldo de um tecido tão aéreo que, tecido, se eleva por si: luz balão. "

$\mathrm{Na}$ verdade, podemos pensar que nossa vida foi, está sendo e será constituida pelo grito de muitos 'galos', que relembramos do passado ao presente, e haveremos de lembrar num futuro mais remoto. E nossas manhās, nossos 'tecidos formados' são resultado da contribuição desses 'galos' - pessoas que nos auxiliaram a construir a nossa história - nossos pais, amigos, professores, alunos, entre outros...

A literatura constitui-se como o registro de muitas histórias de vida, e, além das histórias que a maioria dos educadores são, agora, como adultos, ainda capazes de lembrar sobre sua infância, a literatura também contribui sobremaneira na reflexão que a partir de significativos textos podemos fazer, partindo de 
comparações e associações pertinentes aos diferentes assuntos que se queira abordar.

Em geral, a infância é considerada, por unanimidade, pelos educadores, como um momento de extremo significado para a construção de estruturas do desenvolvimento do ser em formação.

A partir das respostas dadas, as constatações dos educadores demonstraram que estão cientes de suas responsabilidades, principalmente no que se refere à perspectiva de que o que for oferecido, agora, às crianças, ficará marcado, para suas vidas futuras

Assim, a literatura, colocada em discussão pelos educadores, aparece, ainda, aquém de uma justa valorização e plena utilização nas escolas de Educação Infantil; no entanto, é vista como veículo indispensável para o incentivo do hábito de leitura e para a formação de valores que irão alicerçar a personalidade das crianças

Mesmo cientes, do valor da infância e da literatura, os educadores precisam, ainda de um respaldo convincente que priorize estes aspectos como imprescindiveis para a criança. Isso demanda uma politica de Educação Infantil que invista nas bases da formação docente

O avanço que conseguimos com o Referencial Curricular Nacional para Educação Infantil, documento que estabelece as diretrizes para o trabalho neste nivel de ensino, e com a Lei de Diretrizes e Bases da Educação, que oficializa a Educação Infantil como inerente à formação básica, demonstra um certo progresso na valorização precipua da literatura para este nivel de ensino; no entanto, a fatia relacionada à abordagem da língua oral e escrita apresentada no mencionado 'Referencial Curricular', ainda demonstra uma visão reducionista sobre a importância do assunto, se considerarmos a amplitude de sua significação para o desenvolvimento infantil.

Além disso, é preciso que haja uma vontade política maior (transformação macro-social) que faça jus à valia da primeira infância, investindo neste nível de ensino, apostando na vivência da literatura, e dos valores nela incutidos, oferecendo a manutenção de capacitações constantes, capazes de dinamizar a prática docente da Educação Infantil, considerando todos os fatores positivos que a literatura pode trazer para a vivência dos valores humanos dentro e fora do contexto escolar, aprimorando as relações e construindo os múltiplos saberes da criança $e$, também do próprio educador por decorrência da (re)significação de sua própria infância (memórias...). 


\subsection{Leitura e memória}

'O que passou nāo conta?, indagarāo

as bocas desprovidas.

Não deixa de valer nunca.

O que passou ensina

com sua garra e seu mel.

Por isso é que agora vou assim

no meu caminho. Publicamente andando."

Thiago de Mello

As histórias lidas e ouvidas acompanham o homem em seu caminhar pela vida através dos tempos, de geração a geração, passando aos descendentes da linhagem humana, informações imprescindiveis para a evolução da espécie, de seus momentos de imperfeição, luta, crise e, também, de aprimoramento, dos valores humanos mais presentes e destacados em cada época.

Antes da escrita, o hábito de contar histórias já se fazia presente entre os homens marcando a presença da oralidade e da transmissão de informações por meio dos grandes mestres orais

MANGUEL (1997) apresenta considerações importantes sobre a questão da oralidade na trajetória da história das histórias:

"(...) O texto escrito no tempo de Sócrates, não era um instrumento comum. Embora existissem livros em número considerável na Atenas do século $V$ a.C. e um comércio incipiente de livros, a prática da leitura privada só se estabeleceu plenamente um século depois, no tempo de Aristóteles - um dos primeiros leitores a reunir uma coleção importante de manuscritos para uso próprio. Era por meio da conversa que as pessoas aprendiam e passavam adiante conhecimentos, e Sócrates pertence a uma linhagem de mestres orais que inclui Moisés, Buda e Jesus Cristo, o qual uma única vez, dizem-nos, escreveu algumas palavras na areia apagando-as em seguida. Para Sócrates, os livros eram auxilios à memória e ao conhecimento, mas os verdadeiros eruditos não deveriam precisar deles. Pouco depois, seus discipulos Platão e Xenofonte lembraram em um livro essa opinião depreciativa sobre livros, e a memória deles de sua memória foi assim presenada para nós, seus futuros leitores.(...)" (p.78)

Embora conheçamos a contribuição da oralidade como precursora da evolução das histórias ouvidas e lidas, não podemos deixar de considerar o marco que representou a escrita para o registro de todo o percurso de várias passagens da história da humanidade.

Com o advento da escrita, o registro das histórias, antes geralmente contadas, propiciou, (de forma sistematizada e organizada basicamente pelo auxilio das letras), o alastramento das informaçōes e o conhecimento sobre situaçōes, fatos e pessoas que construíram com suas vidas a história da história. 
Uma das contribuiçōes da escrita foi trazer ao homem a possibilidade de conhecer o passado de maneira detalhada e duradoura, através do registro de memórias de um povo, de uma civilização ou de uma pessoa ou personagem histórica, em particular.

\section{Segundo MANGUEL (1997)}

"(...) Em 1658, aos dezoito anos de idade, estudando na abadia de Port Royal sob o olhar vigilante dos monges cistercienses, Jean Racine descobriu por acaso um antigo romance grego, Os amores de Teagenes Claricleia, cujas noções de amor trágico ele talvez tenha relembrado anos depois, ao escrever Andrômaco e Berenice. Racine levou o livro para a floresta que cercava a abadia e começara a ler com avidez quando foi surpreendido pelo sacristão, que arrancou o livro das mãos do rapaz e jogou-o numa fogueira. Pouco depois, Racine conseguiu achar um outro exemplar, que também foi descoberto e lançado às chamas. Isso o estimulou a comprar um terceiro exemplar e a decorar o romance inteiro. Então entregou-o ao feroz sacristão, dizendo: ' Agora podes queimar este também, como fizeste com os outros'.(...)" (p.76)

$\mathrm{Na}$ verdade, parece haver uma estreita interligação entre oralidade, escrita e memória. Para refletir sobre esta colocação, podemos abordar alguns pontos importantes:

- uma história ouvida apresenta a riqueza das características marcantes da oralidade, que, aliada a possiveis abordagens gestuais do 'contador', capazes de Ihe conferir a vivacidade e clareza no poder de persuasão do discurso proferido a eventuais 'ouvintes', poderá ser, posteriormente, escrita para garantir o registro mais fidedigno à realidade vivenciada com detalhes, minúcias e precisão de informaçōes, por meio das letras;

- uma história escrita garante o registro dos fatos passados oralmente e pode tornar-se mais duradoura e presente em objetos ou veículos de leitura: livro, revista, jornal entre outros;

- uma história memorizada passa pelas duas situações anteriores e é internalizada no cérebro, veiculo de sua expressão, até o momento em que possua condições físicas para continuar garantido a clareza das informações guardadas na memória.

Dessa forma, podemos pensar na memória como um elemento capaz de sintetizar o armazenamento de histórias ouvidas e lidas e, ao mesmo tempo, garantir a importância e contribuição de cada uma com suas especificidades, para a constituição de histórias da humanidade.

MANGUEL (1997) ressalta algumas colocações que ilustram as reflexões anteriores, enfatizando o valor do registro da história da humanidade para a perpetuação da memória de fatos passados, presentes e futuros, através de diferentes linguagens de expressão artística, que possibilitam a ampliação do conhecimento humano. Todo o homem deseja 'conhecer', mas tem pouco tempo de vida para conseguir fazê-lo de forma abrangente e, neste sentido, o registro de outros conhecimentos reunidos por aqueles que nos antecederam, pode ajudar-nos na ampliação de nossos próprios conhecimentos: 
"(...) Para tanto, Deus deu à alma humana o dom da memória, aos qual temos acesso por meio dos sentidos da visão e audição. De Fournival aprofundou a noção de Sócrates. O caminho para a visão, disse ele, consistia de peintures, imagens; o caminho para a audição, de paroles, palavras. O mérito delas não estava apenas em expor uma imagem ou texto sem nenhum progresso ou variação, mas em recriar no espaço e no tempo do leitor aquilo que fora concebido e expresso em imagens e palavras em outra época e sob céus diferentes. Argumentava De Fournival: ' Quando alguém vê uma história pintada, seja de Tróia ou outra coisa, vêem-se aqueles nobres feitos que foram realizados no passado exatamente como se ainda estivessem presentes. E o mesmo acontece ao se ouvir um texto, pois, quando ouvimos uma história lida em voz alta, escutando os eventos, vemo-los no presente [...] E, quando lês, essa escrita com peinture e parole irá tornar-se presente em tua memória, mesmo quando não estou fisicamente diante de ti.' Ler, segundo De Fournival, enriquecia o presente e atualizava o passado; a memóna prolongava essas qualidades no futuro. Para ele, o livro e não o leitor, preservava e transmitia a memória.(...)" (p.78)

Há, portanto, várias concepções sobre a importância da oralidade, leitura e memória

Muitos pensadores como Sócrates, ao contrário de De Fournival (citado anteriormente como defensor do livro como principal veículo para o registro da memória), defendiam a oralidade como a base de tudo, colocando o texto escrito em segundo plano pelo perigo de não se estar exercitando a memória e, portanto correndo o risco de tudo esquecer

É o que constata MANGUEL (1997) em sua argumentação sobre a história da leitura por meio de uma explanação de Sócrates a seu discípulo Fedro, defendendo a sua causa maior em prol da oralidade:

"(..) Um dia, contou Sócrates a Fedro, o deus Thot do Egito, inventor dos dados, do jogo de damas, dos números, da geometria, da astronomia e da escrita, visitou o rei do Egito e ofereceu-lhe essas invenções para que passasse ao seu povo. O rei discutiu os méritos e as desvantagens de cada um dos presentes do deus, até que Thot chegou à arte da escrita: ' Eis um ramo do conhecimento que irá melhorar a memónia do povo; minha descoberta proporciona uma receita para a memória e para a sabedoria'. Mas o rei não ficou impressionado: 'Se os homens aprenderem isso, o olvido se implantará em suas almas; eles deixarão de exercitar a memória, pois confiarão no que está escrito, e chamarão as coisas à lembrança não de dentro de si mesmo, mas por meio de marcas externas.(..) E não é sabedoria verdadeira o que ofereceis a vossos discipulos, mas apenas sua aparência, pois, ao lhe contar muitas coisas sem lhes ensinar nada, fareis com que pareçam saber muito, embora, em boa parte, não saibam nada. Um leitor, Sócrates advertia a Fedro, 'precisa ser singularmente simplório para acreditar que as palavras escritas podem fazer mais do que recordar a alguém o que ele já sabe.(..) Para Sócrates, o texto lido não passava de palavras, nas quais signo e significado sobrepunham-se com precisão desconcertante... tudo advinha não do próprio texto, mas do leitor.' (p.77)

Após o levantamento de reflexões sobre o papel da memória no registro das histórias ouvidas e lidas, podemos deduzir que, tanto a oralidade quanto a escrita, contribuem, cada uma dentro de seu universo de possibilidades e caracteristicas 
peculiares, para o acervo e aprimoramento da constituição de memórias e estas são indispensáveis para a construção da identidade e autonomia do ser humano.

O homem edifica-se e se conhece melhor ao conhecer o passado, correlacioná-lo ao presente, estruturando-se de maneira mais previsivel e segura para o futuro, por intermédio do conhecimento de vivências de outros personagens presentes nas histórias, sejam elas ouvidas ou lidas

A importância da memória na história de vida do ser é reforçada por ACHARD (1999), vista sob diferentes perspectivas ou abordagens - lembrança ou reminiscência, memória social ou coletiva, memória institucional, memória mitológica, memória registrada, memória do historiador - , apresentando algumas questōes e indagações sobre o que é produzir memória:

"(...) O que é produzir memória? Como a memória é regulada, provada, conservada. ou é rompida, deslocada, restabelecida? De que modo os acontecimentos históricos, mediáticos, culturais - são inscritos ou não na memória, como eles são absorvidos por ela ou produzem nela uma ruptura? Esta questões se desenvolvem nos artigos através de diferentes perspectivas disciplinares, incluindo-se elementos de história, semiótica. sociolinguiistica, análise de discurso. Além disso, a memória em sua materialidade complexa, com ênfase para a relação do texto com a imagem, para a passagem do visivel ao nomeado. Por um lado os textos fundadores de memória: mitos, relatos, enunciados, paráfrases. Por outro, a eficácia simbólica da imagem: a reprodução pictórica, o meio televisual e até objetos arqueológicos. Ficam expostas ao leitor diferentes práticas memoriais presentes na sociedade ocidental, sejam aquelas da Grécia antiga, sejam as que emergem com as recentes mudanças tecnológicas (...) A memória não pode ser provada, não pode ser deduzida de um corpus, mas ela só trabalha ao ser reenquadrada por formulações no discurso concreto em que nos encontramos. "(p.8)

A memória representa, portanto, um aliado do ser, no sentido de auxiliá-lo na construção de sua própria história de vida, através dos fatos registrados dentro de um contexto histórico-social.

O caminho que viemos percorrendo através da história, do passado ao presente, vem-se construindo a cada dia. Na verdade, temos algumas pretensões a alcançar ao longo do percurso; no entanto, o trajeto só se vai compondo à medida que o vamos atravessando... e relembrar o percurso é algo inusitado... Quando nos reportamos às nossas memórias, temos a sensação de estarmos reconstruindo um filme, uma história em que o protagonista somos nós mesmos. É interessante sentir que muitas reflexões feitas neste retrospecto nos fazem ter a certeza de que se tivéssemos uma segunda chance de atuação nesta nossa história, alguns capitulos manteriamos da mesma forma e muitos, talvez, mudariamos...

Quando nos valemos de nossas memórias, percebemos que podemos melhorar o nosso papel dentro de nossa própria história. Em uma análise sobre os nossos erros e acertos, podemos transformar alguns padrões de comportamento já enraizados e, ainda, criar novas formas de atuação, visando ao aprimoramento intra e interpessoal, ou seja, partindo da evolução qualitativa do autoconhecimento alcançarmos, também, um patamar qualitativo em nossa relação com os outros significativos de nossa história, aqueles com os quais dividimos nossa atuação ao longo da vida. 
As memórias de um educador constituem-se, assim, como um rico filão na reflexão sobre suas experiências em sua história de vida. Através delas, ele pode ponderar sobre sua atuação profissional, sem deixar de lado, é claro, o aspecto pessoal - já que este também pode exercer, em determinadas circunstâncias, influência sobre aquele e vice-versa - e reconsiderar ou ressignificar sua postura, seu caminhar na construção da trajetória da educação junto a seus alunos, partindo de dois pressupostos básicos

- utilização das memórias (passado vivido) do educador reconstituindo sua história de vida como educando. Considerando as dificuldades ou situações bem-sucedidas que vivenciou quando aluno, valer-se de um criterioso crivo seletivo: suprimindo ou repetindo, em sua história como educador (presente vivido), as experiências que teve em sua trajetória, aproveitando-as para o aprimoramento de sua atuação profissional vigente;

- utilização das memórias na trajetória de vida como educador, do passado ao presente. Considerando uma abordagem comparativa entre vários trabalhos desempenhados e observados, a partir da atuação de outros profissionais encontrados ao longo do caminho e analisando sua própria atuação profissional, perceber que é possivel (re)construir e dar um novo significado às suas metas de trabalho junto a seus alunos, e demais envolvidos no sistema educacional, através de várias situações bem ou mal-sucedidas, observadas e vivenciadas.

Acreditamos que muitos são os caminhos e não perder o trem da história é um desafio constante que nos persegue como educadores dia após dia. Muitas situações, já claras em nossas histórias vividas, podem auxiliar-nos em nossas reflexões, outras, que ainda estão sendo tecidas, com certeza, nos serão de grande valia em um futuro não muito distante, quando olharemos para trás e refletiremos sobre que o fizemos ou deixamos de fazer, ou o que poderia ter sido feito de outra maneira..., pois no resgatar de nossas memórias desvelamos o que há de mais significativo em nós mesmos.

Partindo das reflexões anteriores, podemos enriquecer nossa discussão por meio da contribuição de SOARES (1991), que enfatiza o valor da história dentro da história de vida de cada um, como se estivéssemos a cada dia tecendo o 'nosso próprio bordado', ou seja, a nossa própria história que é, também, parte integrante da história da humanidade:

"(...) Vamos bordando a nossa vida, sem conhecer por inteiro o risco; representamos o nosso papel, sem conhecer por inteiro a peça. De vez em quando, voltamos a olhar para o bordado já feito e sob ele desvendamos o risco desconhecido; ou para as cenas já representadas, e lemos o texto, antes ignorado. E é então que se pode escrever - como agora faço - a 'história, tal como, de novo, a personagem de $O$ risco dourado: '... esta história que agora vou lembrando, aos poucos recuperando como um bicho-da-seda ou uma aranha vai tirando de si o fio da própria teia'. (Dourado, 1976: 74). A teia é o passado que construimos, desvendando para nós mesmos, tanto quanto para os outros, o risco que guiou o bordado, o texto que dingiu a representação - a lógica (a lógica-em-uso, segundo Kaplan) que não se percebia quando se viveu (e depois se reconstrói - a lógica reconstruida, segundo o mesmo Kaplan, 1975:10)" (pp.28-29) 
$\mathrm{Na}$ (re)construção de sua trajetória de vida, os educadores podem pautarse, de maneira significativa e positiva à sua práxis, nas contribuições oferecidas por suas memórias de vida pessoal e profissional, pois estas podem contribuir para que consigam resgatar fatos e marcos sacralizados em suas histórias de vida, auxiliando-os na reflexão sobre os possiveis erros/hipóteses na elaboração de seu caminho.

Este 'ir e vir' no levantamento dos registros de seu memorial de vida, constituem o sacramento da marca de cada educador na (re)construção de sua própria história. Trata-se de um processo vivo e dinâmico que pode ser comparado ao registro das memórias da histórial evolução da própria educação.

Dessa forma, pensando-se, também, em um pressuposto cíclicoseqüencial, podemos considerar a memória como desencadeadora de um processo em espiral que, representado em um contexto espaço-temporal, confere ao educador instrumentos basilares para a (re)avaliação sistemática e contínua de sua atuação profissional

Neste sentido, alguns fatores podem ser destacados na questão da reflexão ininterrupta sobre a práxis docente

- o passado, visto sob o prisma do hoje, é fator básico para as experiências/aprendizagens presentes e futuras;

- o presente de hoje será, amanhã, o seu passado;

- o que hoje consideramos como um futuro remoto, será, daqui a algum tempo, seu presente.

Sendo assim, a memória, pode ser veículo capaz de nortear o educador no aprimoramento de sua trajetória, por meio da constatação de diversos fatos experienciados, registrados, avaliados, repensados, transformados e, muitas vezes, modificados porque foram (re)significados

A memória possibilita, ainda, o conhecimento abrangente de alguns pontos relevantes quanto à trajetória da educação... da humanidade...

Por intermédio de fatos vivenciados por contribuidores, pesquisadores e educadores que, através dos tempos, registraram com suas experiências as lembranças de seu momento histórico-social, podemos, hoje, desvelar, na essência de suas memórias, os caminhos alternativos capazes de nos conduzir a uma prática de valorização do exercício de educar... de viver... de transformar... de refletir...

Pensando nos caminhos de reconstrução - de nossa própria história e da história da humanidade - , já que dela fazemos parte e nela estamos completamente inseridos, podemos reportar-nos à importância do ofício milenar, passado de geração para geração, da arte de ouvir e contar histórias - o canal para o registro da memória dos valores, crenças e ideais de vida, de tantas e tantas civilizações que passaram, estão passando e ainda passarão sobre a Terra - e, desta forma, aproveitarmos a contribuição que a literatura nos oferece para aprimorarmos o nosso papel de educadores. 


\subsection{Ser professor/ educador/ mestre... Por quê? Para quê? Como? Considerações sobre a formação docente}

'Ensinar exige corporeificação das palavras pelo exemplo.

Ensinar exige reflexão critica sobre a prática.

Ensinar exige alegria e esperança.

Paulo Freire

A escola que propõe ser um espaço de alegria para as crianças, como já foi mencionado anteriormente, necessita fundamentalmente da mediação do professor.

A importância do professor/mediador no tempo e no espaço da alegria na escola reflete-se na memória viva de todos nós que trazemos em nossas lembranças a presença de professores/educadores que jamais conseguiremos esquecer.

GUSDORF (1995) ilustra e enriquece a reflexão sobre a importancia da ação docente em nossas memórias

"Se procurarmos buscar em nossa memória o que ela, de fato, conservou das lembranças relativas à numerosa linhagem de professores que sem deixar nenhum rastro e, em meio àqueles cuja imagem subsiste, nem todos têm a mesma sorte(...) Mas ainda vejo certos gestos, certas atitudes; ainda ouço tal palavra, relativa ou não à aula, mas que me fez refletir; ficou-me o peso de uma zanga ou de uma indignação memorável. Enfim, alguns ainda continuam vivos e presentes em mim: a personalidade deles marcou-me porque discutimos, nos enfrentamos, nos estimamos e, sem dúvida, secretamente, nos amamos. Vivos ou mortos, por mais longe que estejam, viverão em mim até minha morte.(..) Na escola, é o ser humano que aprende e é ele que, mais tarde, se lembra, segundo fidelidades diversas e, porém, coexistentes, perpetuando a criança, 0 adolescente, o jovem de ontem no adulto de hoje. Por essa recapitulação, minha memória armazena em mim a hierarquia cronológica dos meus educadores, para cada um dos quais mantém a atitude, renovadamente diferente, do momento do encontro. "(pp.34-35)

Considerando-se a importância do professor como um verdadeiro mestre, orientador e mediador de situaçōes, não só de informação, mas, primordialmente, de formação, a criança apresenta uma enorme expectativa em relação à postura docente. Na verdade, o que se espera apresentar na escola é algo muito mais profundo do que a mera transmissão de conteúdos intelectuais: espera-se apresentar o valor da vida e pela vida, ou pelo menos, é isto que se pretende estabelecer como meta a ser perseguida. 
O saber do professor não deve pautar-se exclusivamente em contéudos sistematizados e em um despejar continuo de informações. A criança necessita de um suporte espiritual, não como ceita, religião ou qualquer tendência doutrinária, mas no sentido amplo da palavra, envolvendo a reflexão e o experienciar de emoções, sentimentos e valores que enaltecem e valorizam a vida, desencadeando a apropriação do sentido da própria existência

GUSDORF (1995) auxilia-nos, neste sentido, refletindo sobre a existência do homem e a pretensa desconsideração em relação aos aspectos espirituais de sua formação

"(...) Ninguém se ocupa da formação espiritual, mas todas as pessoas se ocupam dela. mesmo aquele que não se ocupa dela (...) Toda vida humana tem necessidade de ser chamada à ordem de si própria. O professor dá ao discipulo, mais ou menos plenamente, a revelação de sua própria existência (...) A pedagogia do mestre desenvolve-se, assim, numa espécie de contraponto da pedagogia do professor. O professor ensina a todos a mesma coisa: o mestre anuncia a cada um uma verdade particular, uma resposta singular e uma realização." (pp.54-56)

Atualmente, sentimos que, na grande maioria de nossas escolas, existe uma lacuna entre o que a instituição, seja ela pública ou particular, deseja transmitir ao aluno - considerando que isto será indispensável à sua formação - e o que o aluno anseia aprender - por considerar que é realmente importante para sua vida.

Este confronto de expectativas acaba, muitas vezes, afastando o aluno da escola, ou dificultando a relação entre ambos: - o primeiro por não se sentir aceito e atendido em suas necessidades e a segunda por considerar que o aluno não está preparado para o sistema escolar. Neste jogo de empurra-empurra, as responsabilidades do fracasso da relação aluno-escola são sempre conferidas ao outro e dificilmente à reflexão do que cada um pode fazer para melhorar a situação compartilhada pelos dois lados da questão.

Considerando-se ser a escola um local com possibilidades e competências construidas dia a dia por seus educadores, espera-se dela não um papel de redentora de todas as mazelas sociais, mas, pelo menos, de um amadurecimento maior até que o do aluno, para refletir sobre alternativas que poderão abrir caminhos para o estreitamento da relação aluno-escola, uma vez que, com a ajuda coletiva e o envolvimento compromissado de seus profissionais, pode elaborar estratégias diversificadas que auxiliarão na construção de vinculos indispensáveis à permanência dos alunos na escola de maneira feliz, prazerosa e significativa para sua vida.

Neste sentido, precisamos pensar em meios criativos e consistentes para oferecer aos nossos alunos uma aprendizagem significativa, ou seja, apresentarIhes fatos, alternativas, discussões que façam diferença para sua vida, que dêem a eles um novo sentido para o seu próprio existir, fazendo uma ponte de significações entre a escola e sua vida, através de uma contextualização aprofundada e criteriosa.

Sendo assim, a escola deve estar preparada para receber os seus alunos. Acreditamos que o ingresso dos alunos na escola pressuponha a permanência nela, 
partindo-se da premissa de que precisa respeitar as expectativas de seus alunos, sem perder de vista, no entanto, suas especificidades de gestão administrativopedagógica

Respeitar os anseios dos alunos tentando aproximá-los cada vez mais da escola não significa entregar-se completa e permissivamente às vontades do alunado... mas sim refletir sobre os interesses discentes e, pensar, simultaneamente, nas propostas educacionais da escola, buscando, nesta conciliação de interesses partilhados, construir um ambiente prazeroso e feliz para a troca de experiências, para a discussão e construção de bases que garantam a vontade de continuar a aprender dos alunos, mesmo fora dos muros da escola e que permitam aos professores, também, sentirem-se felizes e realizados, pela observação e sensação de que estão conseguindo desempenhar seu papel de verdadeiros educadores, buscadores, mediadores e parceiros inseparáveis no processo ensino-aprendizagem.

Este saber seduzir para a vontade de aprender é algo que somente os verdadeiros mestres são capazes de transmitir aos seus alunos. De fato, esta é uma meta a ser perseguida por todos os educadores - ensinar não apenas conteúdos previamente estabelecidos, mas discutir a vida, o sentido e o valor de nossa existência. o trocar e compartilhar, independentemente da disciplina ou área de estudo... estas questões precisam perpassar a cada momento nas situações vivenciadas na escola, sem distinção de situações ou momentos oportunos escolhidos para tal.

Há algum tempo atrás, havia um programa de televisão chamado Vila Sésamo que apresentava brincadeiras, músicas, situações-problema voltadas inteiramente para a criança e seu desenvolvimento afetivo, social e cognitivo. Tratava-se de uma das raridades de programas televisivos preocupados com questões educativas para a infância.

As discussões deste programa eram pertinentes ao dia-a-dia das crianças, abordando suas curiosidades, inseguranças e expectativas na construção de seu conhecimento, principalmente, por meio de dramatizações, fantoches, atores e atrizes conhecidos que representavam situações destinadas ao público infantil.

As mensagens apresentadas neste programa foram muito significativas e prazerosas para minha formação e, até hoje, no vasculhar de minhas memórias de infância, associadas à minha trajetória de educadora, emociono-me ao lembrar da letra e da música apresentada em sua abertura, já que é impossivel não fazer pontes de (re)significações do passado ao presente, considerando, neste caminhar, as metas que devemos buscar para oferecer aos nossos alunos:

"Todo dia é dia... Toda hora é hora de saber que este mundo é seu... Se você for amigo e companheiro com alegria e imaginação...

Vivendo, sorrindo, criando e rindo será muito feliz e todos serão também... " 
A mensagem da música de abertura de Vila Sésamo traduz aquilo que precisamos buscar para oferecer aos nossos alunos: o sonho, a imaginação, saber ser se e se sentir importante a cada dia, vivenciando oportunidades e experiências inesqueciveis. Este é um direito que deve ser conferido a todos com alegria e vida no espaço da escola - local de troca, de construção e de infinitas parcerias entre aqueles que acreditam que vale a pena continuar porque só se forma e transforma cidadãos através da educação - veículo contextualizador e gerador de pontes de significados para a vida. Neste aspecto, o papel do professor é de fundamental importância

Em relação à questão de ser professor, educador ou mestre, parece, a principio. estarmos diante de palavras de igual sentido; no entanto, há uma sutil diferença entre elas

O professor, na verdade, mesmo visto, muitas vezes, como mero transmissor de informações, precisa honrar e defender o seu importante papel de mestre, ou seja de um educador/formador de hábitos, atitudes e valores. Em suas mãos deposita-se o significado da educação, do prazer dado à criança, da alegria que ela precisa sentir por estar na escola para que, assim, mesmo depois desta, continue tendo lembranças felizes do ambiente escolar, do professor/educador/mestre. desejando aprender sempre mais, a partir da semeadura que the foi oferecida com tanto entusiasmo e dedicação.

Seria isto uma utopia? Estamos ainda muito longe desta realidade?

Sabemos que o caminho a percorrer é, ainda, longo e árduo, mas grandes conquistas já foram feitas, em relação à educação, principalmente, em termos legais; embora saibamos que, na prática, estamos, por enquanto, no encaminhamento de muitas questões pendentes. Precisamos acreditar em nosso potencial e continuarmos juntos e unidos, construindo novas pontes para o acesso à valorização de nossa profissão com competência e seriedade, sem deixarmos, jamais de nos sentirmos alegres com o que fazemos, mesmo apesar das dificuldades, pois o grande exercicio de buscar o melhor é já nos sentirmos um pouco melhor, tentando, ao mesmo tempo, melhorar a cada dia, sem esperar para sermos alegres ou felizes somente amanhã... ou em outra ocasião futura ..., sob a condição irrevogável de conseguirmos 'isto ou aquilo'.

Precisamos buscar um pouco de felicidade no nosso dia-a-dia e tentar transmitir isto para nossas crianças, pois é isto que elas esperam de nós: acreditam no que falamos e sentimos - daí nossa maior responsabilidade: somos pontos de contato com a realidade que nossa crianças estão construindo para sua própria vida, podemos transmitir valores ou antivalores, formar ou deformar, alegrar ou entristecer, causar prazer ou aversão.

ALVES (1985) em seu texto Sobre Jequitibás e Eucaliptos, oferece-nos a possibilidade de refletir, profundamente, sobre a importância do professorleducador na vida dos seres humanos, destacando diferenças marcantes entre a atuação de um bom profissional _, que, para ele, è caracterizado como 'o educador', e aquele profissional que não se apresenta de maneira compromissada e séria em relação à educação - que é caracterizado, por ele, como um mero professor... 
"Educadores, onde estarão? Em que covas terão se escondido? Professores, há aos milhares. Mas o professor é profissão, não é algo que se define por dentro, por amor. Educador, ao contrário, não é profissão; é vocação. E toda vocação nasce de um grande amor, de uma grande esperança. Profissões e vocações são como plantas. Vicejam e florescem em nichos ecológicos, naquele conjunto precário de situações que as tomam possiveis e - quem sabe? - necessánas (...) E o educador? Que terá acontecido com ele?(...) Uma vez cortada a floresta virgem, tudo muda. É bem verdade que é possivel plantar eucaliptos, essa raça sem-vergonha que cresce depressa, para substituir as velhas árvores seculares que ninguém viu nascer nem plantou. Para certos gostos, fica até mais bonito: todos enfileirados, em permanente posição de sentido, preparados para o corte. E para o lucro. Acima de tudo, vão-se os mistérios, as sombras não penetradas e desconhecidas, os silêncios. os lugares ainda não visitados. (...) Pode ser que educadores sejam confundidos com professores, da mesma forma como se pode dizer. jequitibá $e$ eucalipto. não é tudo árvore, madeira? No final, não dá tudo no mesmo? Não, não dá tudo no mesmo, porque cada árvore é a revelação de um habitat, cada uma delas tem cidadania num mundo especifico (...) Talvez que um professor seja um funcionário das instituições que gerenciam lagoas e charcos, especialista em reprodução. peça num aparelho ideológico de Estado. Um educador, ao contrário, é um fundador de mundos, mediador de esperanças, pastor de projetos. "(pp.11-3, $18-9,25-6)$

ALVES (1985) contempla-nos, assim, com a grande possibilidade de pensar sobre a formação docente e sua direta relação com a formação da criança... do aluno que temos, como educadores, em nossas mãos, sob a nossa responsabilidade na tarefa de educar de maneira significativa e verdadeira.

O ideal de professor/educador que buscamos parece estar em construção, assim como o ideal de educação que almejamos; contudo refletir e trabalhar pelo alcance desses ideais já constitui um passo a caminho da longa estrada.

O importante é que, ao buscarmos este ideal, independentemente, de quaisquer denominações: professor, educador ou mestre, pensemos na essência desta reflexão e aproveitemos o que há de melhor para construir nossa trajetória, contribuindo para que o profissional que lida com a educaçāo e a assume como o seu oficio, seja, com ela, compromissado, a fim de atingir, de maneira positiva e benéfica, o objetivo maior de sua atuação docente - o aluno/educando em formação. A fim de não rotular uma outra ou outra expressão, adotaremos, em nossa discussão, os dois termos professor/educador de forma indistinta, pois, embora a argumentação de ALVES nos pareça convincente, de acordo com seu ponto de vista pedagógico/educativo, acreditamos ser mais importante do que tudo a postura adequada e séria do profissional docente, que, no caso, pode ser chamado de professor, educador, ou de professor/educador.

Sabemos que o profissional docente ainda percorre dificeis atalhos em busca de sua real valorização e que é muito complexo buscar, ao mesmo tempo, seu próprio valor, o valor da educação e não se esquecer ainda do valor da criança, ou aluno, que tem sob sua responsabilidade.

Nessa perspectiva, è urgente repensarmos os valores que permeiam todo o quadro da educação, partindo de um visão caleidoscópica das diversas situações abrangentes que estes mesmos valores permeiam. 
A respeito dos valores relacionados à prática educativa, NÓVOA (1995) afirma que os ideais da profissão docente de outrora já não correspondem ao quadro atual de nossa realidade, por decorrência da evolução social e da transformação dos sistemas educativos, que, em sua opinião, merecem ser reexaminados

"(...) Os grandes ideais da era escolar necessitam de ser reexaminados, pois já não servem de norte à acção pedagógica e à profissão docente. Por outro lado, o enquadramento normativo fornecido pelo Estado foi-se esvaziando progressivamente e, hoje em dia, só restam tentativas caricaturais de regressar a um tempo passado. Os professores têm de reencontrar novos valores, que não reneguem as reminiscências mais positivas (e utópicas) do idealismo escolar, mas que permitam atribuir um sentido à acção presente. Por outro lado precisam de edificar normas de funcionamento e regulamentações profissionais que substituam os enquadramentos administrativos do Estado. A produção de uma cultura profissional é um trabalho longo, realizado no interior e no exterior da profissão, que obriga a intensas interaç̧ões e partilhas. O novo profissionalismo docente tem de basear-se em regras éticas, nomeadamente no que diz respeito à relação com os restantes actores educativos, e na prestação de serviços de qualidade(...) Os professores encontram-se numa encruzilhada: os tempos são para refazer identidades. A adesão a novos valores pode facilitar a redução das margens de ambiguidade que afectam hoje a profissão docente. E contribuir para que os professores voltem a sentir-se bem na sua pele..."(pp.28-29)

Não se trata de analisar a situação de forma pessimista ou muito realista, as questões ligadas à educação, mas sim de enxergar sem ingenuidade o sistema atual de ensino, percebendo que há muito a ser feito, sem, no entanto, ficar apenas no ato perceber e criticar, sem encarar de frente as circunstâncias e começar, também, a agir.

A crítica é importante, pois a partir dela, pressupõe-se um repensar e um reavaliar, para, posteriormente, chegar-se a um transformar ou modificar qualitativamente; porém, a crítica pela crítica, por si só não basta. Se realmente quisermos construir alicerces sólidos para a educação, precisaremos detectar o que nos aflige ou incomoda e tentar encontrar possiveis soluçōes para resolver as situações de conflito, pois isso é fundamental para a nossa atuação saudável como profissionais equilibrados e satisfeitos com o que fazemos - as crianças, nossos alunos, percebem isso claramente em nós. Mesmo que, muitas vezes, não verbalizemos nossas insatisfações ou descontentamentos, elas nos percebem e nos diagnosticam com uma clareza inquestionável, daí nossa maior responsabilidade em buscarmos nossa plenitude para podermos transmiti-las, também, aos nossos alunos.

Buscar a plenitude - com e apesar de todos obstáculos que conhecemos não parece tarefa fácil. Sabemos que não existem receitas mágicas, nem tampouco fórmulas milagrosas, mas podemos aproveitar a contribuição de parceiros que já percorreram com sua experiência os caminhos da educação e os que a continuam trilhando, e juntos, num trabalho em parceria, procurarmos refletir coletivamente para diminuir as dificuldades, aproveitando reflexōes que funcionam como verdadeira injeção de ânimo, experiências bem-sucedidas e vivências de educadores e contribuidores, que, com seu trabalho, nos conferem a sensação de conforto e esperança para continuar. 
Ao mesmo tempo, è preciso estarmos cientes de que a educação está ligada à questão da eternidade, da busca sem fim; assim, quando atingimos uma meta, logo outra surge... e assim deve ser, caso contrário, não estaríamos falando em educação como um processo dinâmico, de inesgotáveis possibilidades e de emergentes situações.

É preciso pensar sempre que não estamos sozinhos na caminhada e que muitos estão trabalhando conosco buscando os mesmos objetivos em comum: um sistema de ensino que apresente como proposta uma educação contextualizadora, valorizando a profissão docente $e$, conseqüentemente, garantindo ao aluno o seu direito a uma verdadeira aprendizagem significativa.

Nesse sentido, a literatura é plena e rica em exemplos que nos podem auxiliar a repensar o papel do professor/educador, reavaliando posturas, enaltecendo a valorização docente e, principalmente, mostrando-nos que, como já dizia, sabiamente, o mestre Fernando Pessoa: 'tudo vale a pena se a alma não é pequena'.

\subsection{Momento de reflexão:}

\section{Histórias dedicadas a professores/educadores}

'Uma pedagogia voltada para amplas camadas da população 'Minha longa experiência dos homens simples, das crianças e dos animais convenceu-me de que as leis da vida sāo gerais, naturais e válidas para todos os seres. Foi a escolástica que complicou perigosamente o conhecimento dessas leis, fazendo-nos acreditar que o comportamento dos individuos obedece unicamente a dados misteriosos dos quais uma ciência pretensiosa se atribui a paternidade, como numa espécie de reserva à qual as pessoas do povo, inclusive os professores, nāo têm acesso.' (FREINET, 1996) ${ }^{4}$

FREINET (1996), um valoroso educador e contribuidor para a construção de um caminho reflexivo em busca de uma educação significativa, escreveu algumas histórias, capazes de nos suscitar a (re)significação da educação, de nosso papel de educadores e da concepção de criança.

${ }^{4}$ Citação extraida da contracapa do livro de Celestin Freinet - Pedagogia do Bom Senso. São Paulo: Martins Fontes, 1996. 
Para atingir seu intento, Freinet faz uma analogia entre as crianças, os animais, a educação e a vida, oferecendo-nos algumas possibilidades e alternativas para o aprimoramento da postura docente e da escola, por meio de uma pedagogia baseada, fundamentalmente, no bom senso.

Através das histórias escritas Freinet, podemos reforçar a importância da literatura neste construir da educação, por meio do registro de histórias, calcadas em diferentes situações, capazes de nos auxiliar na vivência de fatos, personagens e circunstâncias de extrema valia para o nosso refletir como educadores, oferecendo-nos pistas alternativas e possibilidades para o aprimoramento de nossa atuação docente, com base nas discussões pertinentes a uma significativa Pedagogia do bom senso

A seguir, apresentaremos fragmentos de algumas histórias/textos extraídos do livro de Freinet (Pedagogia do bom senso), a fim de ilustrar, a partir de algumas reflexões, a discussão que vimos fazendo sobre as questões da formação docente.

\section{Pedagogia do bom senso}

"Você vai procurar bem longe os elementos de base da sua pedagogia. Para isso são necessárias condições intelectuais e vocábulos herméticos, cujo segredo só os universitários possuem. E é tradição referir-se a Rabelais, Montaigne e J.J. Rousseau, para só falar dos pensadores cuja reputação é, há muito, incatável.(...) Veja, então, como entre o povo. são tratados e educados os pequenos animais: você encontrará aí a origem dos grandes principios educativos aos quais estamos voltando lentamente, quase que de má vontade (...) Nada de aprendizagem prematura, dirá o caçador. O cão novo demais se cansa e se desencoraja. As suas reações e o seu faro correm o risco de ficar perturbados para sempre (...)Está certo que o cão tem que caçar para se formar, mas não demais ao sabor do seu capricho. A caça é uma coisa séria para a qual o cão novo será treinado em companhia de cães excelentes, tendo apenas que seguir o exemplo deles (...) Apetite e motivação: se você encher o seu cão de petiscos que lhe não the são especificos, se ficar gordo e cevado, por que você quer que ele cace?(...) E eu the digo que, se fôssemos procurar assim, na tradição popular, as práticas milenares do comportamento dos homens na educação dos animais, estariamos em condições de escrever o mais simples e o mais seguro de todos os tratados de pedagogia." (pp.3-4)

O fragmento de texto acima ilustra o pensamento de Freinet sobre a necessidade de aplicação do bom senso na pedagogia, ou seja, em nossa práxis docente.

Faz-nos refletir sobre uma simples, mas profunda e consistente comparação entre os fatos que ocorrem na natureza e a possibilidade de, nós como educadores -, a partir deles, transportarmos para a educação das crianças as verdades universais da vida.

Freinet parece revelar-nos que é vital apropriarmo-nos de uma pedagogia baseada nas circunstâncias vivenciadas no bom senso e no equilibrio natural de todas as coisas, sem haver necessidade de maiores explicações complexas que, muitas vezes, acabam dificultando nossa atuação por excesso de obstáculos que colocamos indevidamente em nosso caminho. Muitas vezes, as dificuldades são criadas por nós mesmos e a nossa prática acaba sendo prejudicada por isso. 
Precisamos resgatar a sabedoria da vida, tentar mediar o trajeto de forma mais simples e, assim, auxiliar nossos alunos no que realmente podemos fazer: apesar das dificuldades...entre o ideal e o real, precisamos trabalhar com 0 possível..., sem, no entanto, perder de vista as nossas metas para não incorrermos no risco de entramos em um processo de acomodação. Essa busca, com certeza, demanda muito esforço, trabalho, determinação, compromisso e esperança do professorleducador.

\section{Os caminhos da verdade}

"Ficava orgulhoso quando eles se saciavam e me gabava de nunca ter levantado a voz. pois ficavam sempre atentos aos meus gestos e aos meus cuidados (...) Duas atitudes! Duas pedagogias! Mas a Escola ri-se da humilde experiência dos pastores! Ela tem os seus imponentes e seculares caminhos, que escritores, sábios, administradores eminentes disseram ser caminhos da verdade: Nada de fraqueza afetiva! Manter a lei! Habituar os alunos a obedecer, mesmo, e sobretudo, quando a ordem dada contrariar suas tendências e desejos. É assim que se formam - se for preciso com as chibatadas e os cães - as personalidades fortes e as almas bem temperadas. E se fossem caminhos da ilusão e de erro? Se qualquer velho pastor nos provasse, com sua experiencia decisiva, que nos estamos esgotando em vão numa luta desigual contra a natureza a a vida; se nos persuadissemos, algum dia, da vaidade orgulhosa desta autoridade formal - material, intelectual e moral -. que o manejo hábil e impiedoso do chicote nos dá! Se reapreendêssemos a acariciar, amar e servir as crianças de caracóis loiros, a segurá-las pela mão nas passagens dificeis, a baixar para elas os galhos que não conseguem alcançar; a nos alegrar ao vê-las satisfeitas, ao fim do dia, com um alimento livremente colhido nas fontes generosas que teriamos feito brotar, se soubéssemos responder aos inquietos apelos dos alunos em dificuldade e nos acalmar com o espetáculo dos saltos de satisfação de seres que sobem até os cumes da cultura, por caminhos que não são forçosamente calvários, mas que são sempre caminhos de vida! Se soubéssemos ajudar as nossas crianças a tornar-se homens!" (pp.4-5)

O fragmento do texto sobre os caminhos da verdade transmite-nos uma mensagem de crença no valor e na importância da relação professor $/$ aluno. A afetividade, neste particular, constitui-se como fator indispensável para o estabelecimento e aprimoramento dos vínculos criados entre o professor/educador e a criança.

Educar é amar no sentido pleno da palavra. Parece haver, ainda, por parte de algumas pessoas um pensamento equivocado, afirmando ser o professor autoritário aquele que realmente consegue o domínio sobre os seus alunos. Essa idéia calca-se, ainda, na afirmação de que é desnecessário e não aconselhável qualquer demonstração afetiva que parta do educador, pois isso the confere uma certa fraqueza diante de seus alunos.

É preciso repensarmos nossa atuação sempre tendo em vista a certeza de que o professor/educador deve possuir a autoridade de mestre e educador - fato incontestável na situação de ensino-aprendizagem-; no entanto, isso não significa que, para tal, deverá ser autoritário, valendo-se de uma posição de poder para dominar seus alunos pela imposição de regras sem discussão ou reflexão, sem o exercicio do diálogo que acreditamos ser o verdadeiro experienciar da cidadania 
que pretendemos construir com nossos alunos, ajudando-os a se tornarem homens de valor.

\section{O bom jardineiro ou o ciclo da educação}

"A educação não é uma fórmula de escola, mas sim uma obra de vida. Há jardineiros ditos modernos ou cientificos que se gabam de obter uma boa colheita, quaisquer que sejam as condições do solo, do clima, da luz ou do esterco. Mas que abundância de enxofre e arseniatos, de inseticidas e caldas! Se isso não for suficiente, escondem-se os cachos de uvas em saquinhos protetores e colhe-se a pera ainda verde, para guardá-la sobre uma camada de algodão onde amadurecerá à vontade. O fruto está salvo, e tem bom valor de mercado. Mas está tão impregnado de tóxicos, que se torna veneno para quem o consome. A árvore que o deu, esgotada e ferida antes do tempo, seca antes mesmo de ter ousado lançar para o céu os seus braços audaciosos. É já na semente, ou no broto, que o jardineiro prudente cuida e prepara o fruto que virá. Se esse fruto é doente, é porque a própria ánore que o gerou estava enferma e degenerada. Não é do fruto que se deve tratar, mas da vida que o produziu. O fruto será o que fizerem dele o solo, a raiz, o ar e a folha. É deles que devemos cuidar, se quisermos enriquecer e garantir a colheita. Se um dia os homens souberem raciocinar sobre a formação de seus filhos como o bom jardineiro raciocina sobre a riqueza do seu pomar, deixarão de seguir os eruditos que, nos seus aritros, produzem frutos envenenados que matam ao mesmo tempo quem os produziu e quem os come..." (p. 7)

Para que a educação seja realmente uma obra de vida, é necessário buscarmos na formação inicial das crianças a consideração à sua real essência.

Trabalhar com os valores humanos, fazendo as crianças vivenciarem as diversas situações de seu trajeto, dividir com seus pais e responsáveis a tarefa de educar e disseminar com a ajuda das crianças as sementes de amor - assim como faz o bom jardineiro, cuidando da base de seu solo, sem envenená-lo, visando ao retorno de uma boa colheita -, pode ser um caminho alternativo para atingirmos as nossas metas e podermos nos considerar bem-sucedidos, como verdadeiros educadores

$\dot{E}$ preciso estarmos cientes de que o sucesso, a realização e a alegria da criança (semente que germinará) correspondem, conseqüentemente, ao nosso sucesso, à nossa realização e à nossa alegria de educadores (jardineiros que cumprem o seu pape/). Trata-se de um princípio metafórico-educativo que ser buscado com afinco, de forma compromissada, competente e ininterrupta.

\section{A vida sempre sobe}

"Começava o dia; as ovelhas haviam deixado o campo onde passaram a noite, e eu saía com o alforje ao ombro, atrás do pastor plácido e sereno.

Caminhava por trilhas cujo segredo só ele conhecia. Nenhum animal à nossa volta- apenas um longínquo sussurro e o tilintar dos chocalhos localizando o rebanho em movimento, entre as estradas e os pinheiros(...)

Foi o velho pastor que me explicou a razão da sua serenidade:

- Garoto, de manhã, os animais sempre sobem. Vão para os cumes. Não é que o pasto lá sempre seja mais abundante ou mais fácil; mas é o instinto do ser lançar os braços 
para o azul do céu e partir ao assalto dos cumes. O capim, conquistado à força de músculos e tenacidade tem um valor exaltante, talvez só por ter sido muito desejado..

$E$ as crianças - diria o pastor - são como as ovelhas: querem subir sempre. Você só terá paz e certeza se souber ajudá-las, às vezes precedê-las na subida aos cumes, ou segui-las... infelizes dos seres domesticados cedo demais, que perderam o sentido da subida e que, como velhos em fim de corrida, preferem, ao ar do espaço e ao azul do céu, a coleira da sujeição e a ração da renúncia!

São bons todos os caminhos que levam para as alturas." (pp. 12-13)

Podemos refletir sobre o trecho acima fazendo uma comparação entre o pastor, que confia sabiamente na condução de suas ovelhas e o professor/educador, que deve ser um bom condutor/mediador de seus alunos, no ofício de educar com a sabedoria e a ponderação de um verdadeiro mestre

Assim como o pastor é cauteloso e tranqüilo junto ao seu rebanho, conhecendo e prevendo suas diversas reações no decorrer do percurso e sendo sábio na condução de todos, o mestre (professor/educador) deve conhecer profundamente os seus alunos, a fim de prever e entender sabiamente suas atitudes - agindo diante deles de maneira construtiva, tentando fazè-los encontrar o melhor caminho, sabendo orientar com calma e sem pressa, respeitando o ritmo da busca de cada um, sem tirar-lhes, em momento algum, a experiência do prazer da descoberta.

\section{Fazer a criança sentir sede}

"Vocês já viram mães-galinhas obrigarem o filho a comer? Elas esperam, de colher na mão. que o paciente entreabra a boca ainda cheia, para enfiarem a ração de sopa Mais uma para o papai! ... E outra para o gatinho! indigestão

Por fim, aquilo transborda. A criança cospe a papa, ou acaba tendo uma

Coloquem essa criança num meio vivo, se possivel comunitário, com possibilidade de se entregar às atividades que fazem parte da sua natureza. Então, às refeições ou antes delas, estará esfomeada. O problema da alimentação mudará de sentido e de espirito. Já não será preciso você empurrar à força uma sopa recusada de antemão, mas sim fornecer somente os materiais suficientes e válidos. Os processos de deglutição e de digestão já não são problema seu.

Não se obriga o cavalo que não está com sede a beber?(...)

Se o aluno não tem sede de conhecimentos, nem qualquer apetite pelo trabalho que você the apresenta, também será trabalho perdido "enfiar-lhe" nos ouvidos as demonstrações mais eloqüentes. Seria como falar com um surdo. Você pode elogiar, acariciar, prometer ou bater ... o cavalo não está com sede! $E$ cuidado: com essa insistência ou essa autoridade bruta, você corre o risco de suscitar nos alunos uma espécie de aversão fisiológica pelo alimento intelectual, e de bloquear, talvez para sempre, os caminhos reais que levam às profundidades fecundas do ser.

Provocar a sede, mesmo que por meios indiretos. Restabelecer os circuitos. Suscitar um apelo interior para o alimento desejado. Então, os olhos se animam, as bocas se abrem, os músculos se agitam. Há a aspiração e não a atonia ou repulsão. As 
aquisições fazem-se agora sem intervenção anormal da sua parte, num ritmo incomparável às normas clássicas da Escola.

É lamentável qualquer método que pretenda fazer beber o cavalo que não está com sede. É bom qualquer método que abra o apetite de saber e estimule a poderosa necessidade de trabalho." (pp. 15-16)

Saber reconhecer os interesses das crianças, estimulá-las e motivá-las à aprendizagem parece ser o melhor caminho para educar plenamente.

Em uma referência a outro texto do mesmo autor intitulado 'A história do cavalo que não está com sede', pela associação à idéia de que não se deve forçar a beber água nem mesmo os animais, e, portanto, partindo de sua comparação entre o respeito à simplicidade da vida - em sua sabedoria de exemplos demonstrados nas mais diversas situações - e sua relação com a educação, podemos considerar que, também. o professor/educador não deve forçar seus alunos a aprenderem o que considera ser importante para eles.

O educador precisa estar atento ao interesse de seus alunos para que assim possa atingi-los e seduzi-los, despertando o gosto pelo 'sabor do saber' alimento intelectual - e o prazer de aprender, mesmo depois do periodo de escolarização. já que a verdadeira educação é aquela que se perpetua pela vida afora

Os exemplos de fragmentos de algumas das histórias apresentadas na obra de FREINET (1996) proporcionam aos professores/educadores uma abrangente possibilidade criativa de rever posturas e valores, encontrando na simplicidade da vida a verdadeira razão de educar

Parece estarmos diante de um presente de Freinet dedicado aos verdadeiros mestres no sentido pleno e amplo da palavra - aqueles que buscam por meio da educação os melhores caminhos a serem trilhados, compartilhando com seus alunos experiências de vida em que juntos possam crescer e aprender, a partir das trocas que compactuam e ressignificam em parceira

Essa contribuição de Freinet chega a nós, educadores, novamente, através da literatura e, mais um vez, podemos perceber que ela constitui-se como um rico veiculo na condução da trajetória da educação, por fornecer elementos indispensáveis à reflexão e discussão de assuntos pertinentes e, ao mesmo tempo, polêmicos, ao aprimoramento da prática docente $e$, conseqüentemente, da aprendizagem significativa da criança.

Talvez resida nesta importante descoberta - baseada na reflexão sobre as pequenas grandes coisas da vida - o segredo do prazer de ser mestre e de poder sentir brilhar nos olhos das crianças a alegria de estar em sintonia com o tempo e o espaço da escola.

Sob esta perspectiva, podemos pensar que a literatura é mola propulsora para uma educação plena e consistente, pois traz em si mesma todas as possibilidades de atuação teórico-prática, apresentando valorosas rotas alternativas, para o nosso trabalho de educadores, já que nos permite fazer reflexões sobre a ética e os valores humanos - a partir das histórias lidas e contadas - fatores capazes de oferecer à criança, desde a mais tenra idade, a 
oportunidade de vivenciar e experienciar situações de grande importância para a sua formação.

Sendo assim, é importante levantarmos algumas discussões a respeito da concepção de criança que temos e da criança que, como educadores, queremos ajudar a formar, pois qualquer proposta educacional que tivermos precisa valer-se do conhecimento da trajetória da história da criança - de onde viemos, onde nos encontramos e para onde estamos indo - para, em um exercício reflexivo, buscarmos os melhores caminhos para a nossa atuação docente que beneficiem, simultaneamente, a criança. 


\section{Capítulo 3}

\subsection{Questões sobre concepção: a criança na história e a história da criança}

'Hoje, como no passado, a tarefa mais importapte

e também mais difícil na criação de uma criança

é ajudá-la a encontrar significado na vida.'

Bruno Bettelheim

A história da criança demonstra que a presença infantil, como fator merecedor de atenção e respeito, no contexto social, só começa a ser considerada muito recentemente.

Em muitos países da Europa, até o século XVIII, a criança era vista como um adulto em miniatura. Vários quadros e registros da época retratam 'os pequenos seres', com posturas e trajes idênticos ao dos adultos. Estes mesmos 'seres' participavam de todas as atividades da familia, de maneira indistinta. Alojavam-se, costumeiramente, nos mesmos aposentos de seus pais e hóspedes da família, sem quaisquer preocupações ou especiais considerações. Integravam-se em jogos de azar e situações de procedência tipicamente adultas.

ARIÉS (1981) comenta em sua obra - História social da criança e da família:

"O tema das crianças jogando a dinheiro os jogos de azar ainda não chocava a opinião pública, pois é encontrado também em cenas que mostram não mais velhøs, soldados ou mendigos, mas personagens sérias como as de Le Nain (...)As crianças também participavam, no lugar que Ihes cabia entre os outros grupos de idade, das festas sazonais que reuniam regularmente toda a coletividade." (pp.92-3)

No Brasil, a trajetória da criança, na evolução sócio-histórica do país, não acontece de forma mais amena, em relação às questões de valorização dos aspectos de desenvolvimento infantil.

Este fato pode ser observado em alguns romances que retratam a realidade social, em diversos momentos vividos pelas familias brasileiras.

O escritor Graciliano Ramos, conhecido por várias obras regionalistas, que se referem a problemas sócio-econômicos do nordeste brasileiro, não se restringe a esse enfoque e apresenta uma visão critica das relações humanas universais.

RAMOS (1945), em sua obra Infância (memórias), oferece-nos uma verdadeira amostra do tratamento injusto que era dispensado, por grande parte dos adultos, às crianças da época:

"(..) As minhas primeiras relações com a justiça foram dolorosas e deixaram-me funda impressão. Eu devia ter quatro ou cinco anos, por ai e figurei na qualidade de réu. Certamente já me haviam feito representar esse papel, mas ninguém me dera a entender 
que se tratava de julgamento. Batiam-me porque podiam bater-me, e isto era natural. Os golpes que recebi antes do caso do cinturão, puramente físicos, desapareciam quando findava a dor (...) Débil e ignorante, incapaz de conversa ou defesa, fui encolher-me num canto, para lá dos caixões verdes (...) Ninguém veio, meu pai me descobriu acocorado e sem fôlego, colado ao muro, e arrancou-me dali violentamente, reclamando um cinturão. Onde estava o cinturão? Eu não sabia, mas era difícil explicar-me: atrapalhava-me, gaguejava, embrutecido, sem atinar com o motivo da raiva. Os modos brutais coléricos, atavam-me; os sons duros morriam, desprovidos de significação (...) Onde estava o cinturão? Impossivel responder. Ainda que tivesse escondido o infame objeto, emudeceria, tão apavorado me achava. Situações deste gênero constituiram as maiores torturas da minha infância, e as conseqüências delas me acompanharam (...) O homem não me perguntava se eu tinha guardado a miserável correia: ordenava que a entregasse imediatamente. Os seus gritos me entravam na cabeça, nunca ninguém se esgoelou de semelhante maneira. Onde estava o cinturão? Hoje não posso ouvir uma pessoa falar alto O coração bate forte. desanima, como se fosse parar, a voz emperra, a vista escurece, uma cólera doida agita coisas adormecidas cá dentro. A horrivel sensação de que me furam os timpanos com pontas de ferro (...) E não percebi direito os movimentos de meu pai. Não o vi aproximar-se do torno e pegar o chicote. A mão cabeluda prendeu-me, arrastou-me para o meio da sala, a folha de couro fustigou-me as costas (...) $E$ ali permaneci, miúdo, insignificante, tão insignificante e miúdo como as aranhas que trabalhavam na telha negra. Foi esse o primeiro contato que tive com a justiça." (RAMOS, 1982: 31-5)

Pela citação de RAMOS (1982), percebemos que o gesto agressivo e incoerente do adulto era predominante e falava sempre mais alto, vetando qualquer tentativa de diálago

A concepção de criança era a de que esta representava um ser inferior, totalmente submisso à vontade e às ordens, mesmo sem lógica, do adulto. Os questionamentos, as perguntas, o direito à reflexão eram, portanto, inexistentes e distantes das possibilidades de uso do universo da criança.

Dessa forma, constatamos que a concepção de criança, de algum tempo atràs. desvinculava-se totalmente de preocupações com o desenvolvimento biopsicossocial da criança.

O trajeto da evolução da história da criança tem percorrido caminhos ingremes e dificeis; no entanto, devemos admitir que muitas conquistas já foram realizadas em termos legais e pedagógicos para uma especial valorização à educação infantil.

Gostariamos de afirmar com convicção que, atualmente, situações como æs citadas anteriormente não mais acontecem, mas talvez isso fosse uma ingênua precipitaçāo... Apesar de todos as avanços galgados, infelizmente, ainda há concepções que não direcionam à criança o seu devido valor e, hoje, por motivos sócio-econômicos e culturais, a criança, muitas vezes, em algumas regiões do Brasil e também de outros países, é colocada situações vexatórias de exploração e negligência aos cuidados e à educação que lhe são de direito, por falta de comprometimento do adulto na valorização da formação básica infantil.

A educação infantil que pretendemos oferecer à criança, como educadores, na escola, está estreitamente ligada à concepção de criança que temos sobre a mesma. 
É preciso, portanto, que reflitamos sobre uma verdadeira concepção de criança, ampliando todas as suas possibilidades para um desenvolvimento integral, oferecendo-Ihe a oportunização de experiências, de vivências e de caminhos justos, coerentes e dignos, que lhes são, com certeza, de direito.

Sendo assim, uma proposta pedagógica que parta de uma concepção de criança que privilegie o seu desenvolvimento e a sua valorização biopsicossocial precisa considerar aspectos antropológicos da história da educação infantil para se pautar não apenas na sociologia da infância, mas na consideração da amplitude de sua história. tirando desse contexto os ensinamentos significativos e evitando repetir as injustiças conferidas à criança no trajeto da evolução da humanidade.

Pensando-se em uma proposta pedagógica significativa, baseada em uma concepção de criança que valorize todas as suas necessidades básicas de desenvolvimento, a literatura pode oferecer-nos inúmeras possibilidades para a reflexão e implementação de um trabalho - bem estruturado, consistente e comprometido - da escola e do professor/educador visando alcançar plenamente às expectativas infantis

ZILBERMAN (1987) faz comentários ilustrativos sobre as discussōes relacionadas à importância da literatura, citando Peukert (1976) que, em sua concepção de criança privilegia a literatura como canal indispensável para o desenvolvimento infantil, pois oferece à criança dois elementos adequados para a conquista da compreensão do real - a história - que apresenta, de maneira sistemática, as relações presentes na realidade, que a criança não pode perceber por conta própria - e a linguagem - que é o mediador entre a criança e o myndo.

\section{Segundo ZILBERMAN (1987)}

"K.W Peukert, estabelecendo um fundamento antropológico para o livro infantil, o que pode se dar somente se estiver centrado na criança, caracteriza o mundo interior desta como um 'espaço vazio'; e explica: 'o espaço vazio não é vazio, porque as crianças não viveram, mas porque não podem ordenar as vivências'. Assim, se a criança - devido não só à sua circunstância social, mas também por razões existenciais - se vê privada ainda de um meio interior a experimentação de mundo, ela necessitará de um suporte fora de si que lhe sinva de auxiliar. É este lugar que a literatura infantil preenche de modo particular (...) 'As histórias infantis desempenham, pois, uma primeira forma de comunicação sistemática das relações da realidade, que aparecem à criança numa objetividade corrente. Ou, por outra: as histórias infantis são uma espécie de teoria especulativa além da atividade imediata social e individual da criança. '(...)" (pp.12-3)

Embora sabendo da importância incontestável da literatura para o desenvolvimento integral do ser, precisamos estar atentos para a implementação de um trabalho na escola - que privilegie as histórias, os textos, enfim as diferentes abordagens literárias de maneira significativa e contextualizada ao universo da criança - , que, ao mesmo tempo, garanta à literatura o significado e o sentido maior que possui em si mesma, não devendo servir de subterfúgio ou pretexto para atividades ou propostas que a considerem como meio um simplesmente, colocandoa em um segundo plano nas experiências ou vivências apresentadas.

Sob esta perspectiva, podemos considerar de vital importância o contato inicial da criança com a literatura, por meio da pré-escola - já que nem sempre podemos garantir que a familia tenha oportunizado à criança experiências 
significativas neste sentido -, que se constitui como momento decisivo e instaurador dos pilares que darão sustentação e alicerce ao desenvolvimento da criança.

\title{
3.2. Educação Infantil e Pré-escola: reflexões sobre a criança pequena
}

\author{
'A função da pré-escola é a de caminhar com a criança, \\ respeitando suas limitações e explorando seu potencial.
}

Para tanto, há necessidade de conhecer por onde se caminha e qual o ponto que se pretende chegar.'

Ivani Fazenda

'(..) Se acreditarmos que apenas a Pré-Escola como educação poderá atender às exigências do desenvolvimento infantil, passa a ser nossa tarefa, resgatarmos a sua função pedagógica. Isso significa, especialmente, criarmos situações estimuladoras para uma criança brasileira, concreta e contextualizada, a partir da leitura do seu estágio evolutivo, de seus interesses espontâneos, de seus valores culturais e de sua realidade sócio-econômica. '

Tereza Maria Borges

A Educação Pré-escolar constitui-se como um nivel de ensino que representa o grande momento significativo para o contato inicial da criança com o ambiente escolar e suas múltiplas oportunidades de ampliação do universo de conhecimento deste ser em formação.

Nesta fase do desenvolvimento, é fundamental que se ofereça à criança todas as possiveis oportunidades de convívio, experimentação, vivências, através de estímulos imprescindiveis ao seu desenvolvimento biopsicossocial.

\section{Segundo NICOLAU (1995):}

“(...) A pré-escola deve ser concebida como uma ação educativa formal ou informal, que tem um fim em si mesma e que, portanto, não se destina nem pode ser mantida para resolver os problemas do ensino de Primeiro Grau, embora colabore, em muito, para a criança apresentar um melhor comportamento de entrada naquele nível de ensino...a educação pré-escolar visa à criação de condições para satisfazer as necessidades básicas da criança, oferecendo-Ihe um clima de bem-estar físico, afetivo, social e intelectual, mediante a proposição de atividades lúdicas que promovam a curiosidade e a espontaneidade, estimulando novas descobertas e o estabelecimento de novas relações a partir do que já se conhece." (pp. 20-1) 
É função básica da Educação Pré-escolar oferecer condições adequadas ao desenvolvimento da criança, considerando desde os aspectos relacionados a uma infra-estrutura conveniente, já que o espaço é fator básico e imprescindivel para as inúmeras possibilidades de expressão da criança - sala de aula, sala ambiente, pátio, área para jogos e atividades lúdicas, entre outras - até os aspectos pedagógicos, que não deixam de estar imbricados à questão do espaço, pois para a efetivação de uma proposta pedagógica, que contemple plenamente a criança, é necessária a existência de fatores físico-ambientais, a fim de que facilitem sua implementação - vivência do tempo ajustado ao ritmo individual de cada criança, da rotina escolar como elemento de previsibilidade que garante a segurança infantil, da adaptação escolar inicial - que se instala e reinstala em novas adaptações decorrentes do processo de socialização (situações de conflito que, geralmente, partem de um desequilíbrio entre os pares colocados em momentos socializantes e depois se acomodam em situações de equilibrio, em ciclos seqüenciais)

Sabemos que, nas maioria das vezes, o espaço ideal não reflete a realidade das escolas de Educação Pré-escolar e que o professor/educador precisa ser muito compromissado, responsável e criativo para que, mesmo na ausència de infraestrutura adequada e de materiais pedagógicos recomendáveis, desenvolva uma proposta pedagógica significativa com seus alunos, substituindo materiais, adequando espaços, criando possibilidades alternativas de atividades que contemplem as expectativas e as necessidades infantis

Não podemos considerar que só a vontade do professor/educador é suficiente para sanar as dificuldades existentes para a implementação de uma verdadeira proposta pedagógica para a Educação Pré-escolar.

Toda melhoria no atendimento à educação passa por uma política educacional que valorize os diversos niveis de ensino, oferecendo as condições necessárias para atingir às metas educativas direcionadas prioritariamente à criança; no entanto, sabemos, também, que mesmo ainda em situações não ideais apesar de alguns avanços alcançados - precisamos não perder de vista os momentos ideais ou menos deficitários - e, ao mesmo tempo, não devemos esmorecer ou nos desmotivar, pois quanto maior é a dificuldade, maior é o desafio... e também maior é a oportunidade para testarmos nossa força, vontade, competência e compromisso profissional de demonstrar que podemos continuar porque acreditamos no que fazemos e que, mesmo a longo prazo, atingiremos nossos horizontes

O mais importante é continuar... parar pode significar retrocesso e inoperância junto aos nossos alunos, que, com certeza, muito esperam de nós.

Em uma analogia ao pensamento de Vygotsky, que considera uma possibilidade de desenvolvimento (capacidade em estado embrionário) - zona de desenvolvimento proximal (ZPD) - entre o nivel real (aquilo que a criança consegue fazer sozinha) e o nivel potencial (aquilo que a criança faz com a ajuda de um mediador, mas que poderá futuramente fazer sozinha), precisamos trabalhar na ZPD da educação, acreditando que seu estado embrionário receberá, aos poucos, a ajuda de mediadores que irão investir na melhoria da qualidade de ensino e, assim, seremos também beneficiados - professores/educadores e alunos/educandos. 
Nessa perspectiva comparativa ao pensamento vygotskiano, na trajetória de nosso caminhar, precisamos determinar e perseguir nossas metas, mesmo com as dificuldades presentes, acreditar em melhores momentos que se desvelarão na educação

Em sintese: entre o ideal - que virá - e o real - que é presente - trabalhar com o possivel - em estado de alerta para as metas visadas

Partindo das reflexões anteriores, o professor/educador sempre terá como meta principal o desenvolvimento integral de seus alunos. Sendo assim, em se tratando de Educação Pré-escolar, sua tarefa básica é a de fornecer, no momento inicial do desenvolvimento da criança, os subsidios indispensáveis para o exercício do pensar da criança, pois isso garantirá as bases da estruturação de sua criticidade, de seu potencial argumentativo, de sua reflexão, enfim da vivência de sua cidadania como ser em formação.

Através de atividades variadas que incluem diversos tipos de estímulo ao pensamento, a criança deve ser desafiada a pensar, apresentar opiniões, ter iniciativa, enfim. tornar-se segura enquanto elemento participativo e, também , responsável por seu meio.

Para RATHS (1977):

"(..) Quando existe acentuação de pensamento no curriculo, os alunos tendem a modificar seu comportamento. Quando existem freqüentes oportunidades para participar de grande diversidade de processos que exigem pensamento, a freqüência de comportamento impulsivo tende a diminuir." (p.2)

Relacionando-se o mundo da criança pré-escolar com diferentes contextos culturais, percebemos que, apesar de haver variações geográficas e sociais, podemos observar caracteristicas consideradas universais quando relacionadas ao pensamento infantil

É óbvio que a criança, ao ingressar no meio escolar, já traz inúmeros conhecimentos e bagagens provenientes de seu meio familiar e de suas múltiplas vivências com outros mediadores - amigos, vizinhos, parentes - elementos responsáveis por uma aprendizagem não sistematizada com conteúdos de escolarização, mas, certamente, permeada, rica e significativamente, pela sabedoria de vida

Para GARDNER(1994), as crianças adquirem conhecimento mesmo em situações de não escolarização, pois através da exploração do mundo apreendem o que chama de compreensões intuitivas sobre o mundo:

"(..)Combinando seus modos sensório-motores de conhecimento com capacidades de uso de simbolos primárias e inteligências emergentes, crianças pequenas vêm a pensar sobre os objetos, eventos e pessoas ao seu redor de maneira coerente. $\mathrm{Na}$ idade de cinco ou seis anos, as crianças desenvolveram sentidos vigorosos de três dimensões de modo relevante. No mundo dos objetos fisicos, desenvolveram uma teoria da matéria; no mundo dos organismos vivos, desenvolveram uma teoria da vida; $e$, no mundo dos seres humanos, desenvolveram uma teoria da mente que incorpora uma teoria do self. Estas teorias são completamentadas pela habilidade em diferentes tipos de desempenho, dominio de um amplo conjunto de roteiros e a reunião de interesses, valores $e$ inteligências mais individualizados. As crianças trazem consigo para a escola este formidável conjunto de teorias 'feitas em casa', capacidades, compreensões, propensões e, 
é claro, estas, por sua vez, influenciam fortemente a maneira com que os novos estudantes aprendem as matérias recentemente encontradas." (pp.76-7)

Sendo assim, percebemos, a cada momento, a importância da escola e do professor/educador na responsabilidade de conhecer as etapas e peculiaridades do desenvolvimento do pensamento infantil, a fim de que possam viabilizar uma coerente e producente prática cotidiana, direcionando-a, sobretudo, aos interesses e possibilidades de compreensão de seus alunos.

A construção do conhecimento reside na sutileza de percebermos os limites discentes: é preciso que estejamos atentos, como freqüentes observadores do comportamento de nossos alunos, para não ficarmos aquém e nem tão pouco irmos além de seu pensar

Esta sutil estratégia do professor/educador de respeito ao ritmo e às possibilidades reais de nossos alunos, assim como aos conhecimentos que trazem de casa para a escola (conhecimentos espontâneos) e a coerência e a ponderação ao apresentar os conhecimentos propostos e sistematizados pela escola (conhecimentos científicos), sem desvalorizar ou desmerecer os anteriores à escolarização, pode garantir e propiciar o interesse e a motivação das crianças envolvidas no processo de ensino e aprendizagem

Reiterando a importância da Educação Pré-Escolar, muitos pesquisadores têm-se dedicado aos estudos referentes ao desenvolvimento cerebral na faixa etária dos primeiros anos de vida.

\section{Conforme citação de ROSSETTI (1997)}

"O cérebro se forma na relação da criança com o meio ambiente, isso ocorre principalmente dos 0 aos 10 anos - e de forma ainda mais acentuada dos 0 aos 3 anos. Crianças que têm pouco estímulo na fase inicial da vida deixam de formar certos 'circuitos' no cérebro. Exemplo clássico é o da criança que nasce com catarata ('mancha' no olho que impede a visão). Se a catarata não é removida até os 2 anos, a criança será cega para sempre - porque faltou estímulo para formar os 'circuitos' que levam impulsos do olho ao cérebro... As principais dicas são simples: leia e conte histórias para os filhos desde pequenos, tenha livros em casa, cante, toque músicas, pinte, passeie. Tudo isso estimula a formação de determinados 'circuitos' no cérebro... O cérebro tem mais de um trilhão de células nervosas(neurônios). Cada uma é como um telefone que se comunica com outras células por sinais eletroquímicos...Há dois fatores determinantes na formação dessas conexões. O primeiro é genético... O segundo fator é ambiental".

Dessa forma, fica evidente o trabalho vital da Educação Pré-Escolar, no sentido preventivo de seu atendimento, de forma a evitar problemas futuros decorrentes da falta de estímulos que deveriam ser destinados, ininterruptamente, a esta etapa do desenvolvimento.

É imprescindivel a reflexão sobre estas colocações, uma vez que, passados estes os anos iniciais do desenvolvimento, em muitos casos, não há como retroceder ou tentar reverter quadros comprometedores à criança - já arraigados em seu primeiro estágio de formação.

Em outros casos, fica dificil resgatar ou reacender etapas significativas suprimidas indevidamente do desenvolvimento da criança. Mesmo que em um trabalho posterior se tente reaver algumas etapas desconsideradas e não estimuladas no desenvolvimento da criança, dificilmente esta estimulação terá o 
mesmo valor que apresentaria se tivesse sido oportunizada no momento em que a criança precisava ser contemplada em suas expectativas e em suas possibilidades.

KASSAR (1977) refere-se a Bloom (EUA), ilustrando a presente discussão:

"(...) Bloom demonstrou que metade dos trabalhos da inteligência humana são formados até a idade de dois anos, e que, dois terços, até a idade de quatro anos. Assim a criança desenvolve tão rapidamente as suas faculdades e se determina tão profundamente durante os primeiros anos de vida, que se lhe deve prestar uma enorme atenção e colocála em uma situação que favoreça ao máximo seu amadurecimento em todos os domínios." (p.20)

DIEUZEIDE (1978), reiterando as observações anteriores afirma que os psicólogos infantis atualmente privilegiam e enfatizam os primeiros anos de vida para a formação da personalidade da criança no tocante ao desenvolvimento das aptidões lógicas e lingüisticas, no equilíbrio emocional e na capacidade de socialização. Segundo suas constataçōes, do ponto de vista do desenvolvimento intelectual, o resultado de pesquisas realizadas mais recentemente indicam que em relação ao nivel do desenvolvimento geral possuido aos 17 anos, pode-se considerar - na relação idade e porcentagem de acervo intelectual adquirido - as seguintes informações:

- aos 4 anos: cerca de $50 \%$

- dos 4 aos 8 anos: $30 \%$

- dos 8 aos 17 anos: $20 \%$

Refletindo-se sobre a estrita relação entre o desenvolvimento cerebral e a Educação Pré-Escolar, tornamo-nos, cada vez mais responsáveis, como educadores, pelo oferecimento de oportunidades que facilitem o aprimoramento das capacidades infantis, desde a mais tenra idade.

Urge que acreditemos em nosso trabalho para que tenhamos instrumentos adequados que garantam nossa segurança na execução das funções pedagógicas da pré-escola.

\section{Para BORGES (1994)}

"Resgatar essa função pedagógica significa, também, percebermos que o papel da Pré-Escola vai além do simples 'pajear' a criança para a mãe. Por outro lado, a expectativa de bom desempenho da criança, nos niveis posteriores de escolaridade, não poderá levarnos a amarrar a função pré-escolar ao treino de habilidades especificas utilizáveis na 1a. série. Deverá, pois, ficar claro que a tão discutida preparação da criança para o ensino de Primeiro Grau, acontecerá na Pré-Escola, no nivel de valores e habilidades gerais. Assim, quando criarmos inúmeras situações com materiais concretos estimulando, com isto, a inteligência infantil; quando ficarmos atentos para que a criança esteja bem consigo mesma e com os outros, que tenha bom dominio corporal, que saiba expressar seus pensamentos e sentimentos, que perceba a função da língua escrita no mundo modemo, que seja curiosa e corajosa para experimentar e testar as suas hipóteses; estaremos, obviamente, não só preparando-a para os desafios da escola, mas também, muito especialmente, para os desafios da própria vida, ou melhor dizendo, resgatando a própria vida dentro da escola..." (pp. 15-6)

Para BORGES (1994), o resgate da função pedagógica está intimamente relacionado ao papel do professor/educador pré-escolar, que deve manter com a criança uma relação de empatia e confiança, vivendo cada momento do processo 
educacional de maneira gratificante e positiva para o desenvolvimento de ambos professor/educador e aluno/educando

Caso contrário, qualquer proposta pedagógica, por melhor que seja, nāo conseguirá ser implementada de forma satisfatória e bem-sucedida na trajetória do processo de ensino e aprendizagem.

\subsection{O professor/educador da criança pequena}

'O educador ideal deve possuir algumas caracteristicas básicas ser observador, ter olhos, ter ouvidos, sensibilidade para perceber as necessidades da criança, do grupo

Deve ser um pensador, pois a reflexāo precede e acompanha a atuação propriamente dita. Maria Lucia A Machado

Após várias reflexões sobre a importância do desenvolvimento infantil, principalmente nos primeiros anos de vida da criança, podemos constatar que a atuação do professor/educador da criança pequena tem papel decisivo na construção de pontes de grande valor em sua trajetória educacional, especialmente no contato inicial com escola que é estabelecido no nivel pré-escolar.

Sendo assim, é preciso que o professor/educador de educação infantil se reveja, a cada momento, como a criança que foi um dia e que, ainda mora em seu interior, para que possa criar caminhos significativos para os seus alunos, tentando suprimir as dificuldades pelas quais passou quando criança e aluno, evitando que situações desagradáveis ou não favoráveis ao desenvolvimento aconteçam àqueles que estão sob sua responsabilidade na tarefa de educar.

DIAS (1997) em sua tese de doutoramento - Saberes essenciais ao educador de primeira infância: uma reflexão na perspectiva de seus protagonistas apresenta alguns depoimentos importantes sobre o professor/educador de criança pequena, ressaltando a idéia de que tem de ser uma pessoa ágil, com recursos de pensamento e ação e muita energia, com o que concordam várias pessoas entrevistadas:

"Eu concordo com esse ponto de vista de que a pessoa tem que ser, ela, uma pessoa com recursos, com energia...tem que ter muita energia, com recursos próprios para estar podendo reagir à demanda da criança. Não é alguma coisa que você possa planeja de antemão." (Maria Malta Campos, p. 264)

"O professor precisa ter disposição para trabalhar a energia da criança de forma positiva. Ter paciência, porque a criança testa os limites, explora; quando não se contenta, testa de novo. Por isto, você precisa estar sempre colocando as coisas como podem ser. Mas, ao mesmo tempo, você precisa ter paciência ao fazer isto, sem se desesperar, achando-se incompetente. "(Lucéia Silva, p. 264) 
Outros entrevistados por DIAS (1997) apresentam colocações relevantes sobre a importância da generosidade, da reflexão, do espaço para a criatividade e da necessidade de uma formação docente consistente, a fim de que o educador alcance suas metas em relação à formação significativa da criança pequena:

"(...) uma qualidade fundamental é a generosidade. Sem generosidade não se aguenta o tranco de ser educador. A generosidade envolve um bem-estar presente, aberto para poder acolher o outro como realmente é, para poder partir da hipótese do outro e não do que gostaria que o outro me dissesse, do que o outro fosse. A generosidade implica em estar consciente, aberto. concentrado. Generosidade implica em abertura para o outro, para o mundo (...) A reflexão é a mola fundamental para quebrar a anestesia do cotidiano, alicerçar apropriação do pensamento. o que obriga o distanciamento da prática pedagógica que desemboca no estudo teórico e na sua sistematização do cotidiano. É ela que sedimenta autoria do sujeito, a possibilidade de tomada de consciência da prática. "(Madalena Freire, pp. 258, 265)

"Temos que deixar que as crianças nos envolvam, temos que Ihes dar espaço para expressar sua criatividade enquanto aprendemos através delas, a não sufocar a nossa ou ao menos encontrar o que dela sobrou... Para transformar a sociedade precisamos de pessoas criativas que sejam capazes de usar sua imaginação. "( Patricia Guedini, p. 263)

"Pensar a formação de educadores para essa faixa etária supõe uma perspectiva do desenvolvimento infantil, de visão de mundo, de formação para a cidadania, de ensino $e$ conseqüentemente de aprendizagem. Sob esse ponto de vista, as teorias de desenvolvimento infantil e sobretudo as contribuições de Jean Piaget, associadas às teorias sócio-interacionistas de Vygotsky e Wallon, entre outros, têm contribuido para a construção de uma maneira diferenciada de entender a criança pequena, diferente da imagem do mini-adulto de outrora. "( Marineide Gomes, p. 268)

Para alguns outros educadores, a observação é a chave-mestra para que o educador possa entender a criança, acompanhando e tirando proveito de todos os sinais que ela oferece como necessidades e expectativas indispensáveis de serem trabalhadas para o seu desenvolvimento:

"A verdadeira essência da educação é a observação. Não serve para nada um amor pedagógico que não se deixa levar pela observação da vida infantil e não abdica do impeto e prazer que sente... ao corrigir às crianças, baseado em sua presumível superioridade intelectual e moral... Mas a observação e somente aqui começa educação toda ação e gesto infantil transforma-se em sinal...de um mundo no qual a criança vive e dá ordens. "(Benjamim, p.262)

"Para melhor conhecer a criança é preciso aprender a vê-la. Observá-la enquanto brinca: o brilho dos olhos, a mudança de expressão do rosto, a movimentação do corpo. Estar atento à maneira como desenha o seu espaço, aprender a ler a maneira como escreve a sua historia (...) É desenho a maneira como organiza as pedras e folhas ao redor do castelo de areia, ou como organiza as panelinhas, os pratos, as colheres na brincadeira 
de casinha (...) Observando a brincadeira livre das crianças pode-se notar diferenças individuais na maneira de dispor seus brinquedos no espaço (...) Entrar no quarto da criança, terminada a brincadeira, mas onde ainda estão presentes os seus vestigios, é entrar em contato com um recorte da história daquela criança. É a possibilidade de conhecer aquela criança através de uma outra linguagem: o desenho de seu espaço lúdico. As bonecas sentadas no chão e os carrinhos enfileirados falam sobre a criança que os arrumou. Contam sobre seu projeto." (Moreira, p.258)

Muitos outros depoimentos de educadores sobre a importância do trabalho do educador de criança pequena poderiam ser apresentados; no entanto, o objeto desta exposição é de apenas fazer um recorte ilustrativo para a nossa reflexão e a partir dele re(significar) a ação docente junto à criança e ao que há de mais significativo para o seu desenvolvimento

\subsection{Desenvolvimento infantil: a importância da literatura}

'O livro é aquele brinquedo, por incrivel que pareça, que, entre um mistério e um segredo, põe idéias na cabeça.' Maria Dinorah

A presente discussão visa apresentar, através de abordagens teóricopráticas, reflexões acerca da valorização da Educação Infantil, por se constituir, esta, como etapa primeira na construção do conhecimento humano.

Buscando a cumplicidade de alguns autores, que compartilham conosco o resgate do valor do nivel pré-escolar, podemos ilustrar tais metas através de colocações como, por exemplo, as de GÓES (1990):

"E as crianças - dizia o pastor - são como as ovelhas: querem subir sempre. Você só terá paz e certeza se souber ajudá-las, às vezes precedê-las na subida aos cumes, ou segui-las... Infelizes dos seres domesticados cedo demais, que perderam o sentido da subida e que, como velhos em fim de corrida, preferem, ao ar do espaço e ao azul do céu, a coleira da sujeição e a ração da renúncia! São bons todos os caminhos que levam para as alturas... Se no 'assalto aos cumes' precisarmos reunir nossas forças para preceder(ou acompanhar) às crianças $e$ jovens alunos, nunca esquecer que muitos deles precisam de nosso alento e apoio. Algumas vezes, até, nos pontos mais ingremes da subida, devemos dar-lhes colo ou carregá-los. Eles, os mais fracos ou desvalidos, também têm o direito ao ar puro das alturas e ao azul do céu..." (p.14)

Nossa proposta é resgatar, a partir destas reflexões, a importância da leitura de histórias às crianças, de forma a auxiliá-las na vivência dos valores, capazes de estruturar, de forma equilibrada, a sua personalidade. 
A literatura infantil com toda a sua riqueza de fantasia, ludicidade, emoção e poesia é elemento de grande interesse ao público infantil, pois, está diretamente ligada ao mundo da imaginação e à criatividade espontânea da criança.

Ainda, segundo afirmação de GÓES(1990):

"A criança/jovem deve ser colocada frente ao livro de literatura infantil e juvenil como leitor ativo, participante, comunicativo. Como um co-autor. Com sua IMAGINAÇÃO = IMAGEM + AÇÃO mobilizada. Portanto, imaginação que trava com a realidade um diálogo/troca constante... A leitura para criança não é, como às vezes se ouve, meio de evasão ou de, apenas, compensação. É um modo de representação do real. Através de um 'fingimento', o leitor re-age, re-avalia, experimenta as próprias emoções e reações. Eis aí a razão da preferência de tantos leitores (crianças, jovens e adultos) por estórias de medo, de terror ... O perigo fingido é mais fácil de experimentar do que a própria realidade. Esta, sim, traumatizante, quase sempre nos seus momentos violentos. A literatura transfigura o real, no espaço da linguagem/imagem, e o faz através do olhar crítico e emocional." (pp.156)

A literatura, de modo geral, constitui-se como um elemento importantíssimo, entre muitos outros, na representação da expressão artistica, canal primeiro conectado à demonstração dos sentimentos, emoções e perspectivas humanas sobre as mais diversas concepções ou visões de mundo.

A presença da literatura, em nossas vidas, data de tempos remotos, já que a linguagem, veiculo primordial da transposição literária, é o fator basilar na formação da história da humanidade.

Através do texto literário, temos acesso ao registro das mais diferentes fontes de abstração que se materializam, através da escrita, tornando-nos conhecedores do pensamento do autor/escritor ou criador.

$\mathrm{Na}$ verdade, o leitor funciona como cúmplice do autor/escritor no processo de compreensão e introjeção do texto literário - processo, este, que vai muito além de uma simples decodificação da escrita, pois envolve a história de vida de cada leitor em particular, sendo que cada um reagirá de forma diferenciada diante de um mesmo texto apresentado ou lido - conferindo a este, maior ou menor valorização, conforme a empatia sentida, ou não, em relação aos temas propostos e a sua ligação ou semelhança aos episódios de vida daquele.

Surge ai, o papel de vital atenção da escola e do professor/educador na tarefa de proporcionar a seus alunos a oportunidade de experienciar o contato com todos os tipos de gêneros literários (reconhecendo-se que a família nem sempre possui consciência sobre o valor da leitura), de forma orientadora e jamais cerceadora ou indicadora de obrigatoriedade, uma vez que, este sistema opressor de cobrança, acaba destruindo ou bloqueando o mais importante item de motivação à literatura: o prazer.

Não se trata do oferecimento de textos com base em um 'espontaneísmo desmedido e aleatório'; no entanto, devemos refletir bastante sobre a necessidade discente de conhecer uma variada gama de histórias ou temas, capazes de auxiliálos no aprimoramento de sua trajetória de vida, na elaboração de seus problemas ou dificuldades gerais de conduta ou procedimento, seja de natureza individual ou coletiva. 
Portanto, através de uma conscientização significante e consistente sobre as reflexões, acima expostas, cabe à escola o fundamental papel de formar educadores e sensibilizar a familia, buscando caminhos teórico-práticos coletivos, auxiliando as crianças a encontrar uma verdadeira harmonia nos passos de seu desenvolvimento sócio-afetivo-cognitivo.

A literatura assume papel de fundamental importáncia no desenvolvimento , já que através dela é possivel penetrarmos no universo infantil, conhecendo seus sonhos, suas fantasias e, assim, proporcionando subsidios para que se conheça melhor e, também, para que conheça melhor o outro, estabelecendo relações de segurança emocional e intelectiva, numa atitude intra e interpessoal, a partir de vivências que estabelece em cumplicidade com o enredo e as personagens das histórias

É importante que a criança tenha contato com livros desde a mais tenra idade. Mesmo que ainda não tenha desenvolvido os mecanismos de decifração do código escrito, mesmo que não reconheça letras ou números, não importa... O que realmente é importante diz respeito aos vínculos que devem ser criados, desde cedo, em nivel sensorial: o bebê em sua banheira já pode manusear, sentir os livros emborrachados, resistentes à água, com figuras, palavras, ou não. Mais tarde, a criança pode ter contato com livros de pano. Posteriormente, poderá manusear livros de papel, revistas, jornais. Podem haver diferentes tipos de interesse em relação ao material dos livros oferecidos ao manuseio das crianças, contudo o que merece mais atenção é o fato de que o contato com o livro seja feito de forma gradual e prazerosa, pois, só desta forma, conseguiremos seduzir, aos poucos e com o auxilio do caráter lúdico do livro, o pequeno futuro leitor, desenvolvendo neste, através da fantasia e imaginação, uma proposital sedução e cumplicidade em relação à função social da leitura

Se tentarmos forçar a criança a se apropriar do livro, ou de qualquer outro instrumento ligado à leitura, através de elementos que denotem obrigação e dever, sem quaisquer outros atrativos que a motive, isto poderá causar sérios bloqueios à futura vida da criança como leitor

$\dot{E}$ por isso que muitos jovens e adultos apresentam verdadeira aversão e ojeriza à leitura. Fogem dos livros como crianças traumatizadas que, de alguma maneira, foram forçadas a fazer algo que não thes causava "prazer" ou "satisfação".

O prazer de ouvir e contar histórias alia-se em determinadas situações a diversas possibilidades de expressão da criança - cantar, dramatizar, desenhar personagens são exemplos de alguns procedimentos que o adulto pode propor, inicialmente, como mediadores, facilitadores e motivadores na aproximação da criança ao mundo da literatura.

Contando histórias para a criança, reportamo-nos a uma arte secular que remonta aos primórdios da humanidade.

Através das histórias, resgatamos todos os elementos do inconsciente coletivo, registrados nos casos vividos pelos mais diferentes tipos de personagens que, na verdade, apenas trocam de nome e cenário, pois, as emoções, os conflitos, as tramas psicológicas, acabam repetindo-se através dos tempos: é a história dos homens de cada época ou momento histórico que se repete nas histórias que vivemos no presente e haveremos de viver no futuro. 
Ouvindo histórias, entramos em um processo de catarse, ou seja, colocamo-nos no lugar do outro, revivemos sentimentos, elaboramos supostos finais para os enredos propostos, enfim, participamos como cúmplices, de forma mais segura, já que temos a conviç̧ão de que, em nossa realidade vigente tais histórias não nos podem afetar diretamente; no entanto, mesmo assim, nos emocionamos e nos sentimos parceiros nas situações vivenciadas pelas personagens, torcendo para que sejam bem ou mal-sucedidas em suas atitudes, dependendo do juizo que traçamos a seu respeito. Trata-se de um jogo entre o autor/contador e o leitor/ouvinte que se constrói no decorrer das histórias.

Dessa forma, 'o contar histórias' constitui-se como um fator terapêutico para as pessoas de todas as faixas etárias.

Para DINORAH(1995):

"(...)se os pais tivessem consciência da importância de contar um história ao pé da cama pra seus pequenos, certamente teríamos uma adolescência menos traumatizada.

A voz do pai ou da mãe passando pros meninos os componentes mágicos algo tão inerente à sua própria infância - supre-as de uma afetividade diária nem sempre possivel na realidade brasileira, e que irá minimizar os conflitos ocasionados em seu crescimento, por falta dessa mesma afetividade. Uma história incorporada ao sonho de uma criança é esperança e força nos momentos difíceis da vida e, certamente, enriquecimento da velhice, quando as lembranças da meninice se tornam muito presentes... A fantasia e a magia de uma história não só encanta e desperta a imaginação criadora, como é responsável pelos inventores e criadores... Contar histórias é uma arte. E nem todo professor nasce com o privilégio desse dom. Entretanto, o uso de alguns recursos fará dele, se não o artista de dotes excepcionais, um mestre capaz de transmitir com segurança e entusiasmo um texto para os pequenos." (pp. 49-50)

Considerando-se a importância do professor/educador no momento de se contar histórias, há alguns tópicos a serem ponderados conforme colocações relevantes de CUNHA (1995):

"(...) o bom contador de histórias necessita:

- acreditar na realidade da ficção,

- ser natural e discreto,

- evitar as adaptações, lendo o que está escrito no livro,

- não fugir das palavras difíceis,

- não explicar demais,

- lembrar que toda história é um ponto de encontro,

- lembrar que toda história é um ponto de partida para outras atividades,

- a moral da história é nenhuma, ou melhor, várias. Quem descobre é a criança". (p.47).

Percebemos que múltiplas são as contribuições da literatura para o desenvolvimento da criança e este fato tem causado algumas discussões polêmicas 
sobre o verdadeiro sentido da literatura em relação às pessoas para as quais se destina e também em relação à amplitude de suas abordagens.

Sendo assim, vale-nos levantar algumas reflexões sobre o significado e as origens da literatura no decorrer da história. 


\section{Capítulo 4}

\subsection{O cerne de toda a história... Afinal, o que é literatura?}

'A literatura continuará a ser o que é para cada um, independentemente do que os outros digam que ela é.'

Marisa Lajolo

Muito se tem perguntado e tentado definir sobre o significado da literatura e, na verdade, até hoje, podemos considerar que não existe uma única resposta.certa e definitiva.

Na definição de Aurélio Buarque de Holanda, a literatura é apresentada da seguinte forma

"LITERATURA [do lat. litteratura] S.F. 1. Arte de compor ou escrever trabalhos artisticos em prosa ou verso. 2. O conjunto de trabalhos literários de um pais ou duma época. 3. Os homens de letras: A literatura brasileira fez-se representar no colóquio.de Lisboa. 4. A vida literária. 5. A carreira das letras. 6. O conjunto de conhecimentos relativos às obras ou aos autores literários: estudante de literatura brasileira; manual de literatura portuguesa. 7. Qualquer dos usos estéticos da linguagem: literatura oral q.v. 8. Fam. Irrealidade, ficção: Sonhador, tudo quanto diz é literatura. 9. Bibliografia: Já é bem extensa a literatura da física nuclear. 10. Conjunto de escritos de propaganda de um produto industrial." (p.q45)

Certamente, são diversas as situações de uso da palavra literatura, mas, de forma geral, parece que o conceito que se tem desta forma de expressão artística aliada ao uso da linguagem, pode mudar ou assumir diferentes significados dependendo do contexto sócio-histórico vigente.

Dessa forma, o que é considerado como texto literário em determinado momento da história, pode não o ser em outro momento, devido a circunstâncias sociais, culturais, e até mesmo políticas, advindas de padrões e valores distintos de um determinado tempo. literatura:

LAJOLO (1995) apresenta algumas colocações pertinentes em relação à

"(..) A literatura leva ao extremo a ambigüidade da linguagem: ao mesmo tempo em que cola o homem às coisas, diminuindo o espaço entre o nome e o objeto nomeado, a literatura dá a medida do artificial e do provisório da relação. Sugere o arbitrário da significação, a fragilidade da aliança e, no limite, a irredutibilidade de cada ser. É, pois, esta linguagem instauradora de realidade e fundante de sentidos a linguagem de que se tece a literatura. Nada, entretanto de receitas literánias. Nem prescriçães, nem proscrições. Toda e qualquer palavra, toda e qualquer construção lingüistica pode figurar no texto e literalizá-lo. Ou, ao contrário, não literalizá-lo coisa nenhuma, apesar de todo o pedigri literário que certas palavras e construções parecem arrastar atrás de si. Não é, portanto, o uso deste ou daquele tipo de linguagem que vai configurar a literatura (...) É a relação que as palavras estabelecem com o contexto, com a situação de produção e leitura que instaura a natureza literária de um texto (...) Mas, seja como for, mesmo de uma perspectiva intelectual, as 
definições propostas para literatura importam menos do que o caminho percorrido para chegar a elas. Ou, como dizia Fernando Pessoa, o que importa é esperar D. Sebastiåo, quer venha ou não." (pp. 27, 38)

Outras questões a respeito da literatura giram em torno de șua especificidade

- Haveria uma Literatura Geral e outra exclusivamente Infantil?

- Qual seria o critério para se considerar uma história como literária? Ela deve ser necessariamente escrita?

Se pensarmos profundamente sobre a perpetuação das histórias ouvidas, contadas ou lidas, na trajetória da humanidade, poderemos deduzir que qualquer manifestação de uma atividade intelectual por intermédio da palavra cai no domínio da literatura.

Nesse sentido, a literatura não abrange apenas a palavra escrita, mas também a palavra pronunciada. Por isso, o fato de usar a literatura como forma de expressão, com ou sem utilização da escrita, já designa o fenômeno literário. Sendo assim, podemos constatar que a literatura precede o alfabeto e as pessoas iletradas também possuem a sua literatura.

Os povos primitivos, ou grupos alheios às disciplinas de leitura e escrita, também possuem literatura em sua cultura, pois através de seus cânticos, de suas lendas, de suas histórias, de seus provérbios, de adivinhações e representações dramáticas, exemplificam sua vasta herança literária, transmitida de boca em boca, de memória em memória, através da história.

As afirmações de MEIRELES (1984) podem ilustrar as reflexões acima apresentadas:

"(..) Essa é a Literatura oral que, quando se escreve é como registro folclórico. Registro que não impede a continuação da sua vida sob aquela forma que lhe é própria, e na qual sofre as transformações que os homens e os tempos the vão imprimindo, sem a corromperem. Esta digressão sobre a Literatura considerada em seus dois vastos aspectos - o escrito e o oral - permite uma pergunta: 'A Literatura Infantil faz parte.dessa Literatura Geral?' Pergunta a que se poderiam acrescentar mais estas: 'Existe uma Literatura Infantil?' 'Como caracterizá-la?' (...) Evidentemente, tudo é uma Literatura só. A dificuldade está em delimitar o que se considera como especialmente do âmbito infantil. São as crianças, na verdade, que o delimitam, com sua preferência. Costuma-se classificar como Literatura Infantil o que para elas se escreve. Seria mais acertado, talvez, assim classificar o que elas lêem com utilidade e prazer. Não haveria, pois, uma Literatura Infantil a prioni, mas a posterior"'.(pp.19-20)

Considerando o grande valor da literatura para o desenvolvimento $\theta$ construção da identidade de todos os seres - já que a literatura, em suas diversas formas de manifestação se constitui como um riquissimo e incomparável canal de expressão que acompanha o homem através dos tempos, transportando registros de vida de inúmeras civilizações -, é preciso que tenha o respaldo e o devido reconhecimento por parte da escola e dos professores/educadores, colocando-a à disposição dos alunos de forma conveniente, prazerosa e oportunizadora, a fim de que possam estabelecer contato ininterrupto com este precioso caminho para a formação integral do ser. 


\section{Segundo CUNHA (1995):}

"(..) pretendemos que criança e jovem tenham, pela vida afora, a literatura como forma de enriquecimento. Esse é um objetivo louvável: sabemos que a leitura é uma forma altamente ativa de lazer. Em vez de propiciar sobretudo repouso e alienação(daí, massificação), como ocorre com formas passivas de lazer, a leitura exige um maior grau de consciência e atenção, uma participação efetiva do recebedor-leitor. Seria, pois, muito importante que a escola procurasse desenvolver no aluno formas ativas de lazer - aquelas que tornam o individuo mais crítico e criativo, mais consciente e produtivo. A literatura teria pape/ relevante nesse aspecto...". (47)

A referida autora elenca alguns fatores que devem ser considerados no cuidado que a escola e o professor/educador devem ter ao implementar uma proposta pedagógica que realmente invista na significação da literatura para a criança.

Dentre os fatores a serem considerados são citados:

- a importância da escolha do livro para a criança: quanto maior o repertório melhor a oportunidade de vivência, atendendo ao crivo de interesse da criança;

- a ilustração do livro: a criança pequena precisa de muitas gravuras criativas, significativas e conotativas, permitindo que ela extrapole o desenho com sua criatividade, indo para muito além dele. Quando começar a ler ainda deve ter contato com a ilustração e o texto deve ser pequeno, com letras grandes e redondas. Ã medida que se-aprofundar na leitura, as ilustrações tendem a- diminuir, assim como o tamanho das letras e o formato do livro;

- adequação da obra à faixa etária da criança: considerar não só as fases do desenvolvimento infantil, mas, principalmente, sua história, suas experiências e ligações com o livro.

Continuando as colocações de CUNHA (1995), há caracteristicas e interesses especificos de acordo com a faixa etária das crianças que podem nortear o trabalho do professorleducador como facilitador na aproximação destas ao mundo da literatura

- Primeira fase - fase do mito (3/4 a 7/8 anos) predomina nelas a fantasia. o animismo: tanto quanto as pessoas, os objetos têm para a criança, alma, reações... Não existe para ela diferença entre realidade e fantasia. Os contos de fada, as lendas, os mitos e as fábulas são especialmente adequados a essa idade;

- Segunda fase - robinsonismo (7/8 a 11/12 anos) se caracteriza pelo conhecimento da realidade... Interessa-se pela experiência do homem e da criança...Esta fase é chamada robinsonismo, porque serve de modelo à época do herói de Daniel Defoe, Robinson Crusoé. A literatura adequada às crianças dessa idade é o romance de aventura, o relato histórico;

- Terceira fase - pensamento racional (de $11 / 12$ até a adolescência). Começa na criança o dominio das noções abstratas. Preocupa-se 
consigo, mas em sua relação com os outros... A literatura romântica, pelo caráter de seus heróis e por seus temas, é muito bem aceita nessa idade.

$\dot{E}$ importante que se reflita sempre sobre a adequação do livro para a criança. É óbvio que não existe fórmula ou receita pronta para tal; no entanto, há critérios facilitadores, como os sugeridos anteriormente, que nos podem auxiliar na busca de caminhos mais próximos ao encontro da motivação e do interesse de nossos alunos e do público infantil, considerados leitores, em geral

Dependerá do compromisso e da seriedade do trabalho da escola e do professor/educador no atendimento aos fatores preponderantes na escolha de significativas abordagens - que possam ser oferecidas à criança, no vivenciar da literatura -, o interesse infantil, ou não, por este universo de inigualável valor, indipensável à formação integral

O trabalho de oportunização de experiências com a literatura deve ser realizado com as crianças desde a mais tenra idade. Sabemos que à escola esta responsabilidade fica cada vez mais pertinente, pois muitas familias já não possuem condições de oferecer experiências de leitura a seus filhos por fatores diversos, que vão desde a falta de valorização da literatura até à própria visão que têm sobre concepção de criança e educação, ou muitas vezes até pela inexistência de membros da familia que se interessem em fazê-lo... Enfim, não adianta, apenas, levantarmos as dificuldades. na verdade, temos que tentar suprimi-las ou, pelo menos tentar amenizá-las dentro de nosso papel de educadores.

Isso não significa que a escola e o professor/educador devem resolver os problemas sociais, no entanto, de acordo com suas atribuições no contexto educacional não podem deixar de oferecer à criança todo o repertório de conhecimento literário que lhe é de direito

Podemos constatar que a literatura, de forma geral, seja ela proveniente de histórias contadas ou lidas, constitui-se como elemento de rico valor para a criança e deve ser tratada com o sentido próprio e maior que lhe é de direito para que, mesmo servindo como ponte para discussões de determinados temas abordados, sempre seja colocada em um primeiro plano desencadeador de uma abordagem ampla e abrangente - que só ela possui - a fim de que não seja usada como pretexto para o alcance de determinados outros fins, que a coloquem em um nivel secundário de reflexão, pois ela em si mesma é o próprio cerne de toda reflexão.

\subsection{Literatura: eixo central da história}

\section{não é e nem deve ser pretexto}

' (...) A literatura não era um privilégio dos que liam, mas uma espécie de celebração coletiva, além de cumprir o papel que lhe estava reservado, ainda tinha a chance de repercutir profundamente na vida de cada um. (...) ' 
A literatura pode auxiliar o professor/educador trazendo à criança possibilidades de compreensão do mundo e da reflexão sobre sua presença nele.

Trata-se de um elemento desencadeador de conhecimentos diversos que fazem parte da vida da criança, pois representa a história de vida da humanidade, de maneira universal e, ao mesmo tempo, contextualiza a história de vida da humanidade à história de vida de cada um, em particular.

Partindo deste pressuposto, podemos considerar a literatura como eixo de um currículo voltado para um trabalho que priorize os valores necessários à criança na trajetória de seu desenvolvimento, que se construa a partir da vivência e da reflexão sobre sua conduta intrapessoal (conhecimento de si mesma) e interpessoal (conhecimento do outro).

Este trabalho de vivência da valores pode e deve ser feito com o objetivo de sensibilizar e motivar a criança a se (re)descobrir a partir das experiências que vivenciar, por meio do contato que tiver com as diversas histórias com as quais mantiver conhecimento.

Sabemos que a literatura não é e nem deve ser pretexto para quaisquer tipos de abordagens cognitivas, afetivas ou sociais; no entanto ela se constitui indiscutivelmente como um tema que perpassa a todo o momento a vivência da criança dentro e fora da escola, sendo portanto inerente a todo tipo de proposta pedagógica que nos propusermos a desenvolver.

Para que um texto, uma história, ou seja, a literatura de modo geral, não se torne pretexto, é necessário, antes de mais nada que o professor/educador seja um leitor maduro, ou melhor que tenha tido contato com vários tipos de texto, para que só assim possa contagiar seus alunos com sua paixão pela literatura.

De outra forma, se não se fizer acreditar pela sua própria postura desmotivada em relação à literatura - sendo incoerente e não convincente na relação discurso/prática - não conseguirá a credibilidade e o interesse de seus alunos e, com certeza a literatura só será pretexto para o estudo ou discussão de assuntos fragmentados e não contextualizados.

\section{Para LAJOLO (1982):}

"O privilégio da leitura do mestre decorre do fato seguinte: geralmente a leitura do leitor maduro é mais abrangente do que a do leitor imaturo (...) É a maturidade do leitor, construída ao longo da intimidade com muitos e muitos textos. Leitor maduro é aquele para quem cada nova leitura desloca e altera o significado de tudo o que ele já leu, tomando mais profunda sua compreensáo dos livros, das gentes, da vida." (p.53)

Cabe ao professor/ educador refletir sobre os textos que irá propor a seus alunos, pois deles dependerá a construção e vivência de valores ou preconceitos que poderão ser saudáveis ou não para o desenvolvimento de seus alunos.

Dessa forma, o professor/educador, como leitor maduro deve tomar cuidado para não atrofiar a sensibilidade de seus alunos tentando dissecar textos com pontos irrelevantes à sua essência e, ao mesmo tempo, não deixar escapar pontos indispensáveis para a discussão dos alunos, fazendo intervençöes, causando desequilibrios, visando o (re)equilíbrio..., buscando sempre o processo de reflexåo 
sobre os textos apresentados e caminhos para que a literatura como eixo maior de reflexão possa ser útil à construção integral - biopsicossocial - de seus alunos.

É necessário que a criticidade seja um elemento permanente e norteador na atitude do professor/educador, para que, tanto ele, quanto seus alunos, possam integrar-se e entregar-se aojogo e à essência do texto, com verdadeiro significado, estabelecendo saltos qualitativos em sua evolução como seres integros e integrais, a partir do tecer de vários textos que se vão acoplando e re(significando) a essência dos valores e da vida.

LAJOLO (1982) dá-nos uma outra importante contribuição para aprofundar as reflexões feitas anteriormente:

"Ler não é decifrar, como num jogo de adivinhações, o sentido de um texto. É, a partir de um texto, ser capaz de atribuir-lhe significação, conseguir relacioná-lo a todos os outros textos significativos para cada um, reconhecer nele o tipo de leitura que seu autor pretendia e, dono da própria vontade, entregar-se a esta leitura, ou rebelar-se contra ela, propondo outra não prevista. E tudo isso, ou seja, as atividades que caracterizam o bom leitor, começa a nascer ou morrer a partir dos sete anos, da alfabetização, nos primeiros contatos do aluno com o texto. Tudo o que vem depois é só reforço e terapia." (p.59)

Considerando as palavras de LAJOLO (1982), percebemos a importância do contato inicial da criança com a literatura e, poderiamos acrescentar, ainda, que este interesse e contato nasce, muitas vezes, antes da alfabetização, dependendo do estímulo que a criança recebe e das oportunidades que Ihe são oferecidas para aproximar-se do mundo da literatura.

Mesmo não sendo alfabetizada, a criança pode ser ouvinte de histórias e, assim, também, estabelecer outros contatos aproximativos à literatura como manusear livros, olhar os textos nele apresentados, observar as ilustrações, tecer comentários sobre os assuntos apresentados, entre outros.

Segundo CARVALHO (1990):

"O fato de uma criança não saber ler não é obstáculo para que tenha idéias bem precisas sobre as caracteristicas que um texto escrito deve possuir para que permita um ato de leitura. No entanto, para que isso ocorra, é necessário que a criança esteja familiarizada com a lingua escrita (...) As crianças não esperam passivamente que alguém Ihes dê sinal verde para 'iniciar o seu processo de alfabetização (...) No contato com uma ampla gama de textos, a criança poderá contextualizar a lingua escrita através de seus usos, mesmo antes de se tornar efetivamente capaz de ler e escrever (...) Literatura é arte, é expressão estética e não doutrinação. Considerando-se estes aspectos no trabalho junto às crianças, o texto literário pode abrir-lhes possibilidades muito grandes de compreensão de si mesmo, da realidade que as cerca, do que seja a leitura, das convenções lingüisticas e das diferenças entre a linguagem oral e a escrita." (p.108)

Se o professorleducador estabelecer oportunidades capazes de estimular a criança neste contato com a literatura desde a pré-escola, mesmo antes de ser alfabetizada, gradativamente, ela irá perceber a função social da leitura $\Theta$ da escrita, pois gostando das histórias ouvidas - contadas por alguém que demonstre paixảo pelo universo da literatura - , irá, com certeza, interessar-se, conseqüentemente, pela forma de registro/escrita destas mesmas histórias $\theta$ de outras, $\theta$, no futuro, motivar-se-á pela leitura de outras várias histórias por si mesma, $e$ a escrever, também, suas próprias histórias. 
Dessa forma, do estímulo inicial e das oportunidades oferecidas à criança, desde a mais tenra idade e no nivel primeiro de sua formação básica - pré-escola dependerá o surgimento de possiveis futuros leitores e escritores que encontrarão sempre na literatura o prazer e a paixão de conhecer o mundo; no entanto, isso só será possivel se houver um trabalho de contextualização a partir das experiências propostas neste aproximar da literatura, pois se não for significativo à criança, causará o movimento contrário de aversão decorrente do estabelecimento da leitura e da escrita por obrigação, para atender às exigências fragmentadas, puramente conteudistas, impostas pela escola, na ansiedade de atender às suas próprias expectativas, esquecendo que o objetivo maior da educação é o de atender às expectativas da criança.

Estas reflexões levam-nos a perceber que o sentido da literatura se manifesta em sua plenitude no texto e isso jamais poderá deixar de ser discutido com a criança, aproveitando cada nuance no trabalho com o texto das histórias, contextualizando o começo, o meio e o fim, fazendo com que qualquer atividade proposta - das quais o texto participa - tenham sentido, a fim de que o texto sempre resguarde o seu significado maior.

Nesse sentido, LAJOLO (1982) ilustra a importancia do trabalho significativo com a linguagem, mostrando que ela perpassa pelo aluno e pelo professor/educador de maneira distinta e, ao mesmo tempo, contextualizada a partir de referenciais já tecidos por cada um como leitor ou ouvinte de histórias:

"Com a linguagem não pode haver pressa. Há o texto dos alunos, o nosso de professores e os textos alheios. Todos se tecem de palavras, todos têm seu ritmo. A relação entre eles é de diálogo: um provoca o outro, o significado de cada um desafia $e$ refaz o significado seu e dos outros. É a partir do texto que cada um, a cada momento, vive a grande aventura (...)" (p.62)

$\mathrm{Na}$ grande aventura do texto, ou melhor no contato estabelecido com o mundo da literatura, o leitor/ouvinte poderá encontrar significados novos para sua própria vida e reencontrar ou (re)significar valores já adquiridos.

$E$ neste ir e vir, a criança vai, aos poucos construindo e estabelecendo relações indispensáveis à sua formação integral a partir de vínculos construidos com a literatura desde a educação infantil.

\subsection{Literatura Infantil e a construção do ser: múltiplas aprendizagens}

' Os estudantes aprendem de modos que sāo identificavelmente distintos.

O amplo espectro de estudantes e talvez da sociedede como um todo estaria melhor senvido se as disciplinas pudessem ser apresentedes de diversos modos $\theta$ a eprendizegem pudesse ser abordade etravés de mejos varledos.' Howard Gardner 
Aproveitando o especial enfoque dado à Educação Pré-Escolar, aliado à importância da Literatura infantil para o desenvolvimento da criança, nossa intenção é oferecer, aqui, sugestões de atividades para a prática cotidiana, nas quais, a partir de histórias, possamos aprimorar e elaborar, de forma cada vez mais significativa, as múltiplas inteligências infantis, vivenciando os Valores Humanos nas mais diversas situações do dia-a-dia

Como exemplo de sugestão, podemos citar a leitura de histórias relacionadas à literatura folclórica ou às obras clássicas da literatura infantil, pois estas caracterizam-se como fontes preciosas da cultura popular e, portanto, de grande interesse infantil.

$$
\text { Conforme citação de COELHO (1993): }
$$

“(...) Segundo dados da Psicologia, a mentalidade popular e a infantil identificamse entre si por uma consciência primária na apreensão do eu interior ou da realidade exterior...Em outras palavras, no povo (ou no homem primitivo) e na criança, 0 conhecimento da realidade se dá através do sensivel, do emotivo, da intuição...e não através do racional ou da inteligência intelectiva, como acontece com a mente adulta e culta, Em ambos predomina o pensamento mágico, com sua lógica própria. Daí que o popular e o infantil se sintam atraidos pelas mesmas realidades...Prosseguindo nessa linha de raciocinio, compreende-se por que certa literatura que teve largo sucesso entre os povos antigos (de interesses já tão distantes de nossa realidade atual) continue agradando às massa populares ou às crianças de hoje, como é o caso da literatura folclórica, ou das obras 'clássicas' da literatura infantil. Atentando-se para a natureza dessa literatura, vemos que sua matéria pertence à área do maravilhoso, da fábula, dos mitos ou das lendas, cuja linguagem metafórica se comunica facilmente com o pensamento mágico, natural nos seres intelectualmente imaturos. " (pp.36-8)

Nesse sentido. podemos pensar na apresentação de histórias que sejam do interesse coletivo das crianças e trabalhá-las de forma criativa, enfocando todas as possiveis alternativas que possam percorrer as vivências de Valores Humanos, por meio das diferentes situações emergentes.

Para tal trajetória, GÓES (1990) oferece-nos algumas orientações, alertando-nos para certos cuidados em relação à necessidade de se colocar à disposição da criança todo o acervo literário possível, oportunizando condições adequadas para a leitura, ou seja, a organização de uma rotina que favoreça sempre a aproximação ao universo da literatura, seduzindo-a, motivando-a, sem apresentar dificuldades de acesso:

“(...)a menina reivindica livros. Sim, criança quer livros: à mão, para ler e escolher à vontade...Portanto, local (cantinho), estante, caixotes com variedade de livros atraentes e de boa qualidade. Não esquecer de aliar o acesso à liberdade de ler gostoso (horário livre de leitura sem cobranças) e acesso durante o recreio para quem quiser ler, poder fazê-lo. Nem todos os dias, nossos músculos e nosso ânimo pedem corridas e jogos. Ler também é recreação! Nada de armários trancados; burocracia dificil e amedrontadora: preencher requisição/ aprovação/ severidade/ castigos... Espaço suficiente para brincar, descontrair, passar horas de 'estudo-descoberta' em laboratórios, cantos de leitura, oficinas de arte, atividades emocionantes. Sala de leitura : com mesas e cadeiras para quem quiser, 
almofadões fofos para a 'viagem' ser um vôo bem emocionante. Nas paredes da sala de aula, assim como nos corredores da escola, painéis culturais' quentes e atuais'... Os painéis informariam sobre tudo(em cultura) a todos... O conhecimento de opções de lazer, também essenciais, educam para a vida e é um autêntico aprendizado cultural." (pp. 19-20)

$\dot{E}$ preciso que se trabalhe com as histórias desenvolvendo atividades interdisciplinares diversificadas, buscando idéias criativas e inusitadas que atraiam o interesse infantil, sempre e mais.

A partir de uma história podemos propor que as crianças representem, desenhem, cantem, montem jogos, recriem tramas do enredo, realizem atividades extraclasse, enfim, que exercitem as suas múltiplas inteligências, favorecendo, por conseguinte a vivência dos Valores Humanos, propondo resolução de situações de conflito, por meio das relações e peculiaridades das personagens e enredos apresentados em diferentes áreas do saber

Além das sugestões acima expostas, muitas experiências sensoriais também podem ser oferecidas à criança, sempre a partir de uma história, ou visando a preparação da clientela infantil para a apresentação de diferentes temas, ou ainda, aproximando-a e sensibilizando-a, na assimilação de um assunto enfocado.

\section{Segundo OAKLANDER (1980)}

"(...) Escrevo sobre como proporcionar à criança experiências que a tragam de volta para si mesma, experiências que renovem e fortaleçam sua consciência daqueles sentidos básicos que o bebê descobre e nos quais floresce: visão, som, tato, paladar e olfato. É através deles que experienciamos a nós mesmos e estabelecemos contato com o mundo(...) Interessante observar que muitos desses exercicios podem ser encontrados em livros relacionados com a arte dramática, bem como em livros educativos destinados à criatividade no uso da linguagem. Pessoas envolvidas nestes dois campos há muito reconheceram a necessidade de proporcionar a crianças e adultos muitas experiências sensoriais de modo a aumentar suas habilidades. "( $p .131)$

A prática cotidiana resulta, assim, da preocupação constante da escola e do professor/educador em procurar oferecer infinitas oportunidades de aprendizagem à criança, com o objetivo de torná-la segura e equilibrada, através da vivência e da descoberta de suas reais capacidades, estruturando de forma equilibrada o seu universo interior, por intermédio do conhecimento de si mesma e do outro.

É importante que o professor/educador não se esqueça, porém, de que a literatura deve ser o ponto central de toda a atividade oferecida, pois representa o eixo da reflexão, o ponto desencadeador das descobertas infantis. O que pode vir atrelado à história é apenas um suporte para aprofundamento das experiências da criança, digamos que seja um recurso a mais para a sua vivência de valores e situações da vida prática.

O importante é voltar sempre à premissa de que a literatura não é e nem deve ser pretexto para quaisquer propostas pedagógicas, o que seria uma incoerência, pois é fato que ela representa o cerne de tudo, tendo garantido a sua posição superior nas mais diversas situações vivenciadas. 


\title{
4.4. Caminhos possiveis para uma escola prazerosa:
}

\author{
Educação- Literatura e Psicanálise
}

\author{
'(.) O educador inspirado por idéias psicanaliticas \\ renuncia a uma atividade excessivamente programada, \\ instituida, controlada com rigor obsessivo. \\ Aprende que pode organizar seu saber \\ mas não tem controle sobre os efeitos \\ que produz sobre seus alunos.(..) \\ Pode-se dizer, por isso,
} que a Psicanálise pode transmitir ao educador uma ética, um modo de ver e de entender sua prática educativa. (...) ' Maria Cristina Kupfer

Mesmo se considerando a distinção do binômio Educação \& Psicanálise, podemos pensar em um trabalho em parceria entre ambas, visando, sobretudo, a evolução qualitativa da relação professor/educador - criança e do contexto escolar como um todo organizado e equilibrado.

$\mathrm{Na}$ verdade, a Educaçāo, em algumas situações, ou em grande parte destas, acaba impondo critérios de procedimento à criança, praticamente, obrigando-a a seguir diretrizes estáveis preestabelecidas, muitas vezes sem refletir sobre as mesmas

A Psicanálise, ao contrário, não impõe, discute fatos, mas não pode decidir por ninguém, e nem é este o seu objetivo, já que representa associação livre, não podendo ser estruturada ou amarrada a uma metodologia: se assim o fosse, perderia sua possibilidade de criação.

Partindo da premissa anterior, é possivel levantar algumas hipóteses sobre a adequação de determinadas abordagens da Psicanálise associadas a um trabalho capaz de tornar a escola um lugar prazeroso, por meio de uma Educação calcada em um olhar diferenciado oferecido às crianças.

Nesse sentido, apresentaremos, aqui, uma sugestão de trabalho significativo com as crianças, os alunos/sujeitos, que torna possivel mais um caminho alternativo para a estruturação interior do sujeito, considerando suas ansiedades, incertezas, inseguranças e, também, suas fantasias, por intermédio do oferecimento de oportunidades que descortinem o especial significado da vida.

BETTELHEIM (1980) oferece-nos reflexões indispensáveis para pensarmos sobre o 'sentido da vida', refletido a respeito do 'porquê' de nossa existência e a necessidade de se encontrar o 'desejo de viver':

"(...) É bem sabido que muitos perderam o desejo de viver, e pararam de tentá-lo, porque o significado Ihes escapou. Uma compreensão do significado da própria vida não é subitamente adquirido numa certa idade, nem mesmo quando se alcança a maturidade cronológica. Ao contrário, a aquisição de uma compreensão segura do que o significado da própria vida pode ou deveria ser é o que constitui uma maturidade psicológica. E esta 
realização é o resultado final de um longo desenvolvimento: a cada idade buscamos e devemos ser capazes de achar alguma quantidade módica de significado congruente com o 'quanto' nossa mente e compreensão já se desenvolveram (...) Infelizmente, muitos pais querem que as mentes dos filhos funcionem como as suas - como se uma compreensão madura sobre nós mesmos e o mundo, e nossas idéias sobre o significado da vida não tivessem que se desenvolver tão lentamente quanto nossos corpos e mentes. Hoje, como no passado, a tarefa mais importante e também mais dificil na criação de uma criança é ajudá-la a encontrar significado na vida. Muitas experiências são necessárias para se chegar a isso. A criança, à medida que se desenvolve, deve aprender passo a passo a se entender melhor; com isto, torna-se mais capaz de entender os outros, e eventualmente pode-se relacionar com eles de forma mutuamente satisfória e significativa.(...)" (pp. 11-2)

A descoberta do significado da vida pode auxiliar o sujeito em sua estruturação interior. Isto nos leva a crer que este trabalho de descoberta pode servir de ponte, aproximando, gradativamente, o sujeito à escola que se propuser a fazê-lo

BETTELHEIM (1980) completa sua colocação anterior sobre o significado da vida, enfocando o papel da literatura, especialmente, dos contos de fada inventados muito antes que a sociedade de massa surgisse - , mostrando-os como capazes de ensinar mais sobre os problemas interiores dos seres humanos do que qualquer outro recurso literário e enfatizando a necessidade de se estabelecer pontes de contextualização, ou seja, de se oferecer obras que façam sentido e dêem significado à vida da criança:

"(...) Os livros e as cartilhas onde se aprende a ler na escola são destinados ao ensino das habilidades necessárias, independentemente do significado. A maioria da chamada 'literatura infantil' tenta divertir ou informar, ou as duas coisas. Mas grande parte destes livros são tão superficiais em substância que pouco significado pode-se obter deles. A aquisição de habilidades, inclusive a de ler, fica destituida de valor quando o que se aprendeu a ler não acrescenta nada de importante à nossa vida... a idéia de que, aprendendo a ler, a pessoa, mais tarde, poderá enriquecer sua vida é vivenciada como uma promessa vazia quando as estórias que a criança escuta ou está lendo no momento são ocas. A pior caracteristica destes livros infantis é que logram a criança no que ela deveria ganhar com a experiência da literatura acesso ao significado mais profundo e àquilo que é significativo para ela neste estágio de desenvolvimento. Para que uma estória realmente prenda a atenção da criança, deve entretê-la e despertar sua curiosidade. Mas para enriquecer sua vida, deve estimular-lhe sua imaginação: ajudá-la a desenvolver seu intelecto e a tornar claras suas emoções; estar harmonizada com suas ansiedades $e$ aspirações; reconhecer plenamente suas dificuldades e, ao mesmo tempo, sugerir soluções para os problemas que a perturbam. Resumindo, deve de uma só vez relacionarse com todos os aspectos de sua personalidade - e isso sem nunca menosprezar a criança, buscando dar inteiro crédito a seus predicamentos e no seu futuro." (pp.12-3)

Auxiliar a criança a se estruturar interiormente não é tarefa fácil, mesmo porque, nem, todo professor/educador possui conhecimentos aprofundados sobre a Psicanálise e nem cabe a ele esta função específica; no entanto, por meio do trabalho com os contos de fada, pode oferecer uma riqueza de significados $e$ descobertas importantíssimas para o seu aluno, sem ter, é claro a pretensão de 
fazer quaisquer abordagens ou diagnósticos psicanalíticos, já que não é esta a sua atribuição de educador, mas podendo oportunizar situaçōes de vivências muito significativas para a criança.

Sob este aspecto, BETTELHEIM (1980) enfatiza que se a criança vivenciar situações que a auxilie em sua elaboração interior, mesmo que de forma inconsciente, conseguirá, mais facilmente, lidar com suas dificuldades e conflitos típicos do ser humano - como medos, inseguranças, rivalidades..._ , e desenvolver-se de maneira saudável e equilibrada:

"(...) Para dominar os problemas psicológicos do crescimento - superar decepções narcisistas, dilemas edipicos, rivalidades fraternas, ser capaz de abandonar dependências infantis: obter um sentimento de individualidade e de autovalorização, e um sentido de obrigação moral - a criança necessita entender o que está se passando dentro de seu eu inconsciente. Ela pode atingir essa compreensão, e com isto a habilidade de lidar com as coisas. não através da compreensão racional da natureza e conteúdo de seu inconsciente, mas familiarizando-se com ele através de devaneios prolongados ruminando, reorganizando e fantasiando sobre elementos adequados da estória em resposta a pressões inconscientes. Com isto, a criança adequa o conteúdo inconsciente às fantasias conscientes, o que a capacita a lidar com este conteúdo. É aqui que os contos de fadas têm um valor inigualável, conquanto oferecem novas dimensões à imaginação da criança que ela não poderia descobrir verdadeiramente por si só. Ainda mais importante: a forma e estrutura dos contos de fadas sugerem imagens à criança com as quais ela pode estruturar seus devaneios e com eles dar melhor direção à sua vida.(...)" (p.16)

A partir das reflexões anteriores sobre a importância dos contos de fada na estruturação interior do ser, apresentaremos, a seguir, uma sugestão de trabalho que pode ser aplicado visando à vivência de experiências significativas para a criança, tomando como exemplo o estudo da história "O Príncipe Encantado", segundo referência da abordagem dos contos de fada sugerida por Jung.

AMARILHA (1997) apresenta o estudo acima mencionado, partindo, inicialmente, da exposição do enredo de "O rei sapo", título original do conto que se popularizou em algumas versões com o nome de "O Príncipe Encantado".

" Havia um rei que possuia várias filhas muito bonitas, sendo a caçula a mais bela. A princesa mais jovem costumava brincar com sua bola na floresta próxima a um poço. Certo dia, a bola cai no poço. A princesa se desespera e concorda em se tornar amiga de um sapo que se apresenta para recuperar o brinquedo. Assim que obtém o objeto de volta, a princesa se refugia no palácio não cumprindo a promessa feita ao coachante. No dia seguinte, o sapo vem reclamar os direitos do acordo, o rei pergunta à filha sobre o acontecido, ao que a obriga a aceitar o animal como seu amigo. Quando a princesa concorda em tê-lo em sua cama, o sapo se transforma em um belo príncipe. " (p. 69)

AMARILHA (1997) apresenta alguns aspectos relevantes sobre o conto acima, justificando a análise, que será feita posteriormente, a seu respeito, tendo como base o método de Jung: 
" (...) A vantagem do método de Jung para a análise dos contos de fada é que, ao invés de conceber cada personagem como figura representativa de diferentes seres humanos, considera cada personagem um aspecto da mesma personalidade, porque cada personalidade é múltipla. Dessa forma, reestabelece a complexidade da representação humana nas narrativas (...) Para Jung (1988), os contos são produtos da fantasia $e$ expressão 'espontânea' do inconsciente, da mesma forma que os sonhos, pois os contos e os sonhos possuem estrutura dramática, com personagens, conflito e solução. Segundo Jung. os contos de fada são o resultado do relato de sonhos individuais nas sociedades primitivas. Ora, neste tipo de sociedade, tudo é vivido coletivamente. Não há, portanto, um conceito de privacidade. Assim, em algum momento, algum individuo faz irromper através do sonho um conteúdo inconsciente da coletividade. Esse sonho, uma vez narrado para o grupo social, organiza-se em conto, sendo ampliado ou simplificado. Dessa forma, mantêmse os eventos psicológicos em narrativas. Dai Jung considerar a importância dos contos de fada tanto quanto a dos sonhos, pois seriam momentos diferentes de um mesmo evento interior. (...)" (p. 70)

A apresentação do trabalho com os contos de fada pode ser muito útil para a estruturação do interior do ser humano, por meio da vivência das personagens da narrativa. demonstrando a importância da repetição de fatos da vida, como algo inerente à coletividade, através da trajetória/ história da humanidade, desde as sociedades mais primitivas. Isto, para a criança é muito significativo e edificante, pois através de diferentes histórias, pode assegurar-se por meio de experiências apresentadas, e, a partir delas, reestruturar-se, redescobrindo-se em suas inseguranças, medos ou incertezas pessoais, reelaborando, assim, o significado de sua própria vida

AMARILHA (1997) continua a exposição em relação à abordagem de Jung com colocaçōes significativas ao explanar sobre a importância dos arquétipos modelos de atitudes ou situações preservadas pelo inconsciente humano _, na mensagem que os contos de fada são capazes de transmitir. mesmo que de forma não consciente

"(...) Ao sofrer as alterações do tempo, da migração de um local para outro, os contos acabam se reduzindo a uma estrutura esquemática, mas presenam na simplicidade as estruturas arquetipicas básicas da experiência humana. Os arquétipos na linguagem de Jung são modelos de atitudes ou de situações que o ser humano preserva através do inconsciente. Assim sendo, os contos de fada são relatos simbólicos de situações cruciais. Os contos estariam, portanto, relacionados mais com um conflito do individuo consigo mesmo do que com o seu ambiente, pois, da mesma forma que os sonhos, os contos são expressão de acontecimentos interiores. Nesse sentido, em 'O Principe Encantado' ocorre uma situação arquetípica de iniciação em que o sapo não representa apenas um aspecto do inconsciente, mas o próprio inconsciente profundo que está cheio de valores escondidos, mas assustadores em sua aparência inicial, uma vez que o desconhecido é sempre amedrontador (TUCKER, 1988, p.87). A iniciação faz parte da condição humana que é um continuo teste de morte e ressurreição. No caso do 'Principe Encantado' , morre o sapo para nascer o principe.(...)" (pp. 70-1).

Por intermédio das experiências vividas pelas personagens da história, é possivel a elaboração de situações dificeis para o leitor/ouvinte, pois, à medida que mantém contato com as histórias, vai, aos poucos, lidando melhor com os seus fantasmas interiores, tendo como apoio as mensagens simbólicas apresentadas através da irresistivel fantasia do mundo encantado dos contos de fada. 
Nesse sentido, AMARILHA (1997) apresenta alguns exemplos ilustrativos, atribuindo significado à presença marcante de duas personagens da narrativa - o rei e a princesa - , que serão apresentados como um recorte significativo capaz de demonstrar pontos imprescindiveis à nossa reflexão sobre a relação literatura $e$ psicanálise. segundo o suporte apresentado pela abordagem do método de Jung:

"(. ) O rei em sociedades primitivas, além de chefe tem qualidades mágicas. Do rei depende o bem-estar físico e psiquico da nação. Ele encarna, portanto, um principio regulador. Pode dizer-se que na narrativa do 'Principe Encantado' ele assume essa função facilitando o contato do lado consciente da princesa com seu inconsciente(...). Sendo o rei o centro da consciência, a atitude da princesa em tentar desobedecê-lo significa a sua resistência à mudança. ao desconhecido. Por outro lado. o rei de 'O Príncipe Encantado' apresenta algumas caracteristicas do arquétipo do velho sábio. O velho sábio sempre aparece quando o herói ou heroina se encontra numa situação dificil que necessite de uma reflexão (..) A função do velho homem e sábio é a de induzir a personagem à reflexão. Dai as perguntas. 'quem é?': 'o que aconteceu?': 'o que ele quer?' Ao responder essas perguntas a princesa recorda a história do encontro com o sapo e, assim, ela reconstitui os passos do ritual iniciático. Dessa forma, a iniciação ou contato com áreas desconhecidas do inconsciente se torna menos angustiante. Por outro lado, ao obrigar a princesa a obedecê-lo. o rei a protege de tomar a sua própria decisão, isto é, protege sua parte consciente que resiste à mudança. A obediência à autoridade facilita a passagem. O rei também introduz conceitos morais na consciência da heroina ao enfatizar o valor da promessa O rei. assim. introduz na consciência da princesa aspectos do animus. Como se sabe para Jung (1988), os dois principios presentes no ser humano são: animus, masculino e anima, feminino. Ao valorizar a contribuição do rei para a solução do conflito da princesa. pode inferir-se a interpretação de Jung para os contos de fada, a de que na expressão do inconsciente está a explicação do que falta ao consciente. (...)" (pp. 71-2)

Dessa forma a partir da aparente simplicidade de uma história, muitas sıtuações podem ser trabalhadas, de forma a auxiliar a criança, o aluno ou o leitor/ouvinte a lidar melhor com seus próprios conflitos interiores, a buscar no adulto, ou em um outro significativo, a segurança de que precisa para se autoafırmar. assim como a princesa encontrou na sabedoria e na determinação do rei a resposta para os seus medos, incertezas e inseguranças

$\mathrm{Na}$ verdade, não houve a pretensão de se fazer, aqui, uma análise aprofundada do conto apresentado, mas apenas de ilustrar a importância dos contos de fada como uma sugestão ou caminho possivel e significativo, em relação ao tema estudado nesta discussão.

O método de Jung representa apenas um exemplo, entre tantos outros importantes e merecedores de estudo, na abordagem da psicanálise dos contos de fada e sua riqueza para a estruturação interior do ser humano, seja qual for a sua faixa etária

Cabe, sobretudo, ao professor/educador, conhecer a realidade de seus alunos para fazer uso desta e de outras abordagens literárias relacionadas, ou não à Psicanálise, considerando sempre que o canal mais profundo e significativo de qualquer temática apresentada deve ser a literatura com o significado primeiro de reflexão em si mesma, sem ser usada como subterfúgio para apresentação de quaisquer outros fins. 
Partindo-se do sentido primordial da literatura para a estruturação do ser, podemos pensar também, neste sentido, em uma reflexão que abarque aspectos referentes a questões relevantes e indispensáveis para o desenvolvimento da criança desde o início de sua formação: os valores humanos, a ética, enfim, a formação moral de modo geral. 


\section{Capítulo 5}

\subsection{A formação moral da criança: Ética nos Parâmetros Curriculares Nacionais e no Referencial Curricular Nacional para a Educação Infantil}

'(..) E, naturalmente, estratégias educacionais para formaçāo moral e ética incidem sobre mudanças pessoais.

Esse é, a meu ver, o lado positivo da volta das preocupações éticas neste final de século. nāo desprezarmos a formaçāo individual e, conseqüentemente, as tarefas educacionais voltadas à formação moral dos alunos.

Mas isso implica também um medo passarmos a pensar que a transformaçāo individual tudo pode e a desprezar, por completo, o plano político. Perigo de alienação, portanto! ‘ Yves de La Taille

As questões ligadas à educação têm-se voltado, cada vez mais, às relações humanas, de modo geral, buscando caminhos que possam aprimorar o interior de todos os envolvidos no processo educacional, partindo da construção e vivência de valores humanos universais, baseados em principios ético-morais.

Geralmente quando se fala em ética, moral e valores, parece-nos que estes termos são muito similares e, de fato, são considerados como sinônimos para muitas pessoas. Na verdade, podemos considerar que a essência do significado destes termos baseia-se, fundamentalmente, em princípios norteadores que visam ao aprimoramento interior do homem, auxiliando-o a refletir sobre sua própria conduta, e, conseqüentemente melhorando suas relações com todos ao seu redor.

No entanto, é importante ressaltar, aqui, algumas especificidades que podem clarificar os termos acima colocados, de forma a perceber que, cada um, traz contribuições indispensáveis para o presente estudo de reflexão.

$\mathrm{Na}$ apresentação da versão preliminar dos Parâmetros Curriculares Nacionais - PCNs - (1996) para o Ensino Fundamental de $1^{a}$ a $4^{a}$ série, são feitos alguns comentários que podem elucidar consideraçōes sobre Ética, Moral e Valores:

"O homem vive em sociedade, convive com outros homens e, portanto, cabe-Ihe pensar sobre e responder à seguinte pergunta: como devo agir perante os outros? Como vemos, a pergunta é fácil de ser formulada. No entanto, é difícil de ser respondida. Ora, esta é a questão central da Moral e da Ética. " (p.2) 
Muitas vezes, as palavras Moral e Ética são empregadas como sinonimias, significando principios ou padrões de conduta; no entanto, há uma sutil diferença entre ambas.

A Ética pode ser entendida como Filosofia da Moral, ou melhor como um pensamento reflexivo, que, a partir da concepção maior do significado da Moral, discute e repensa os valores que direcionam as condutas humanas.

A Moral assume para muitos um sentido pejorativo, sendo associada ao sentido diretivo e extremamente regrado da idéia de moralismo, talvez interpretada, por muitos, com uma conotação de proibição e castração de algumas condutas humanas consideradas inadequadas ou inconvenientes ao convívio social.

Com o objetivo maior de apresentar aos alunos formas de pensarem suas condutas e a dos outros a partir de principios e não de receitas prontas, os PCNs assumem a sinonimia entre Ética e Moral, empregando a expressão clássica na área de educação como 'Educação Moral'.

Isto posto, fica ainda uma indagação em relação às condutas consideradas adequadas no trato com os nossos semelhantes, já que estamos tratando de situações dilemáticas, com diferentes perspectivas de abordagens, considerando-se que cada grupo social assume padrões de convivio de maneira bastante diferenciada, conforme o referencial de valores priorizados por seus integrantes.

Em uma sociedade que privilegia o valor 'vida', por exemplo, seria considerado um delito, ou um ato anti-ético, roubar um remédio para salvar a vida de alguém? E na mesma situação de roubo de um remédio, em um grupo social que privilegiasse o valor 'propriedade privada', isto seria um delito mais grave?

Segundo discussões apresentadas no documento dos PCNs os homens têm reagido, de maneira diferente, através dos tempos, em relação aos valores que privilegiam em determinados momentos de sua trajetória sócio-histórico-cultural:

"(...) Seria um erro pensar que, desde sempre, os homens têm as mesmas respostas para questões deste tipo. Com o passar do tempo, as sociedades mudam e também mudam os homens que as compõem. Na Grécia antiga, por exemplo, a existência de escravos era perfeitamente legitima: as pessoas não eram consideradas iguais entre si, e o fato de umas não terem liberdade era considerado normal. Outro exemplo: até pouco tempo atrás, muitos consideravam as mulheres como seres inferiores aos homens, e, portanto, não merecedoras de direitos iguais (deviam obedecer a seus mandos). Outro exemplo ainda: na ldade Média, a tortura (o suplicio) era considerada prática legítima, seja para a extorsão de confissões, seja como castigo. Hoje, tal prática indigna a maioria das pessoas (infelizmente, não todas), e são consideradas imorais. Portanto, a moralidade humana deve ser pensada historicamente, pensada com referência à sociedade concreta. $E$, decorrentemente, pensar a ética dentro de um currículo pede que reflitamos sobre a sociedade na qual está inserida a escola, no caso, o Brasil." (pp.2-3)

Portanto, toda reflexão a ser feita, neste sentido, deve partir de uma abordagem antropológica e sociológica, conhecendo-se a diversidade de valores presentes na sociedade brasileira, sem nos esquecermos de que devemos partir de um referencial curricular nacional, que tem como objetivo central o exercicio da cidadania, buscando os elementos que nos remetem diretamente às questões morais, por meio de nossa maior referência nacional brasileira - a Constituição Federativa do Brasil, promulgada em 1988. 
Refletir sobre as questões mencionadas anteriormente, auxilia-nos a enxergar, de forma mais abrangente, os fatores ético-morais relacionados sobretudo aos diferentes valores presentes nas diversas sociedades e culturas.

Este estudo, apresentado nos PCNs (1996) mostra-nos o interesse de muitos pesquisadores e educadores/pareceristas, no sentido de aprofundar e estruturar as diretrizes do documento elaborado, tentando atender às pessoas com e apesar de suas diferenças e especificidades.

Sendo assim, o documento final dos PCNs (1997), definido após reelaboração da versão preliminar, acima mencionada, apresenta um oportuno comentário sobre a importância da Ética

- "(.) A Ética interroga sobre a legitimidade de práticas e valores consagrados pela tradição e pelo costume. Abrange tanto a critica das relações entre os grupos, dos grupos nas instituições e perante elas, quanto à dimensão das ações pessoais. Trata-se portanto de discutir o sentido ético da convivência humana nas suas relações com várias dimensões da vida social: o ambiente, a cultura, a sexualidade e a saúde (...)

- A Ética diz respeito às reflexões sobre as condutas humanas. A pergunta ética por excelência é: 'Como agir perante os outros?' Verifica-se que tal pergunta é ampla, complexa e sua resposta implica tomadas de posição valorativas. A questão central das preocupações éticas é a da justiça entendida como inspirada pelos valores de igualdade e eqüidade

- Na escola, o tema Ética encontra-se, em primeiro lugar, nas próprias relações entre os agentes que constituem essa instituição: alunos, professores, funcionários e pais. Em segundo lugar, o tema Ética encontra-se nas disciplinas do currículo, uma vez que, sabe-se. o conhecimento não é neutro, nem impermeável a valores de todo tipo. Finalmente, encontra-se nos demais Temas Transversais, já que de uma forma ou de outra, tratam de valores e normas." (pp.30-2)

Para atingir as metas acima elencadas, o documento dos PCNs (1997) pautou-se em quatro elementos básicos - o respeito mútuo, o diálogo, a justiça e a solidariedade - referenciados a partir do princípio da dignidade do ser humano, inserido na Constituição brasileira de 1988.

Dessa forma, a escola precisa oferecer a seus alunos um trabalho que possibilite o desenvolvimento da autonomia moral, já que esta é a condição indispensável para a reflexão ética.

Os PCNs (1997) apresentam questões básicas para a formação integral do ser humano, partindo do pressuposto de que todos são capazes de aprender, desde que respeitadas as diferenças individuais, culturais e regionais, tendo como suporte diretrizes que garantam a todos o acesso ao processo de ensino-aprendizagem.

Neste sentido, a Ética aparece como elemento indispensável no aprimoramento do ser, pois para aprender e evoluir, em todos os sentidos, preeisa, inicialmente, conhecer-se a si próprio, trabalhar suas dificuldades e, assim, conseguir, também, aprimorar sua relações com os outros.

A proposta dos PCNs (1997), em relação à discussão aqui apresentada sobre a Ética, aparece em continuidade no Referencial Curricular Nacional para a 
Educação Infantil - RCNEI (1998), referente às creches, entidades equivalentes e pré-escolas, integrando os documentos elaborados pelo Ministério da Educação e do Desporto, que buscam auxiliar as crianças no desenvolvimento integral de suas identidades, capazes de crescerem como cidadãos cujos direitos à infância são reconhecidos

O RCNEI (1998) é composto por três volumes:

1- Introdução;

2- Formação Pessoal e Soçial;

3 - Conhecimento de Mundo

Podemos observar, principalmente no que se refere ao volume 2 do RCNEI - Formação Pessoal e Social - , uma atenção especial ao cuidado voltado para o desenvolvimento da identidade e da autonomia, da segurança, e do autoconhecimento que, ao mesmo tempo, aprimora as relaçōes com os outros significativos que fazem parte da vida da criança.

Alguns trechos, retirados do documento acima referido, podem ilustrar melhor a importância de questões inter-relacionadas à Ética, por meio de colocações, relacionadas às necessidades infantis, quanto à formação integral da criança:

"(..) Nos atos cotidianos e em atividades sistematizadas, o que se recomenda é a atenção permanente à questão da independência e autonomia. O exercício da cidadania é um processo que se inicia desde a infância, quando se oferecem às crianças oportunidades de escolha e de autogoverno. (...) Para que seja incorporada pelas crianças, a atitude de aceitação do outro em suas diferenças e particulandades precisa estar presente nos atos e atitudes dos adultos com quem convivem na instituição. Começando pelas diferenças de temperamento, de habilidades e de conhecimentos, até as diferenças de gênero. de etnia e de credo religioso. o respeito a essa diversidade deve permear as relações cotidianas. Uma atenção particular deve ser voltada para as crianças com necessidades especiais que, devido às suas características peculiares, estão mais sujeitas à discriminação. Ao lado dessa atitude geral, podem-se criar situações de aprendizagem em que a questão da diversidade seja tema de conversa ou trabalho (...) " (pp.39-41)

Embora o documento em discussão apresente uma significativa abordagem sobre a questão da cidadania, da cooperação, enfim, poderiamos dizer da Ética, de maneira ampla e abrangente, fica ainda no ar uma indagação sobre a vivência de tudo isso pela criança : como este ser em formação, dentro de suas possibilidades reais e potenciais de apreensão de mundo, apropria-se destas questões tão dialeticamente discutiveis?

Partindo do questionamento anterior, poderiamos pensar na literatura como uma grande aliada do professor/educador e da escola, na construção de pontes significativas entre a vida criança e as questōes relacionadas à Ética, através das histórias apresentadas, discutidas e referendadas de maneira construtiva :ao desenvolvimento infantil.

Neste sentido, o RCNEI (1998) apresenta algumas propostas para o trabalho da linguagem oral e escrita, enfocando aspectos importantes relativos à importância da literatura para a criança. 
No terceiro volume do mesmo documento em questão - RCNEI (1998) são oferecidas discussões sobre a literatura infantil, enfocando que as práticas de leitura precisam ter valor em si mesmas, não sendo necessário haver sempre atividades subseqüentes a ela relacionadas, como desenhos, dramatização, respostas a diversas perguntas, pois a criança poderá desenvolver uma idéia distorcida e equivocada sobre o que é leitura. Poderá imaginar que após uma história sempre deverá haver qualquer outra atividade para lhe conferir maior significado. Tais atividades poderão ocorrer desde que façam parte de um projeto mais amplo e que sejam sempre contextualizadas de forma pertinente à história, permanecendo a ênfase na idéia de que a literatura tem um sentido maior nela mesma, com ou sem proposição de quaisquer atividades posteriores à apresentação de histórias.

O referido documento apresenta ainda a premissa de que a literatura deve ser oportunizada à criança mesmo antes que seja alfabetizada. O contato com o texto, seja ele oral ou escrito, constitui-se como diferentes abordagens de literatura: "As poesias, parlendas, trava-linguas, os jogos de palavras, memorizados e repetidos, possibilitam às crianças atentarem não só aos conteúdos, mas também à forma, aos aspectos sonoros da linguagem, como ritmo e rimas, além das questões culturais e afetivas envolvidas." (volume 3, p. 141)

Nesse sentido, o papel do professor/ educador é fundamental, cabendo a ele oferecer, freqüentemente, diversas possibilidades de contato com a literatura em toda a sua amplitude de gêneros e diversidade de abordagens: "São inúmeras as estratégias das quais o professor pode lançar mão para enriquecer as atividades de leitura, como comentar previamente o assunto do qual trata o texto; fazer com que as crianças levantem hipóteses sobre o tema a partir do título; oferecer informações que situem a leitura; criar um certo suspense, quando for o caso; lembrar de outros textos conhecidos a partir do texto lido; favorecer a conversa entre as crianças para que possam compartilhar o efeito que a leitura produziu, trocar opiniões e comentários etc." (RCNEl, volume 3, p. 142)

O professor/educador precisa mostrar-se como leitor assiduo, demonstrando prazer quando em contato pela literatura, pois só desta forma irá, aos poucos, seduzir e motivar a criança, aproximando-a da literatura em toda a sua amplitude de abordagens. É necessário que perceba as expectativas infantis, pois é comum que as crianças peçam para que as histórias sejam recontadas várias vezes, uma vez que precisam reconhecê-las, apreender seus detalhes, conferir sua seqüência e antecipar as emoções que sentiu pela primeira vez que..ouviu determinadas narrativas.

O RCNEI (1998) apresenta, de modo genérico, contribuições valorosas em relação à literatura. Por meio da proposição do trabalho com as línguas oral e escrita, indica sụgestōes para a prática de leitura e escrita seguidas de orientações didáticas, que podem auxiliar de maneira consistente a atuação do professorleducador: "Comunicar práticas de leitura permite colocar as crianças no papel de 'leitoras', que podem relacionar a linguagem com os textos, os gêneros e os portadores sobre os quais eles se apresentam: livros, bilhetes, revistas, cartas, jornais etc." (volume 3, p. 141).

A proposta apresentada no RCNEl (1998) indica a preocupação em se tratar a literatura como um elemento incipiente e indispensável à formação básica da 
criança neste momento de significativo valor para o seu desenvolvimento integral, que deverá ser continuado e aprofundado em outros niveis de ensino que se seguirão após a Educação Infantil.

O trabalho primordial e imprescindivel com questões relacionadas à Literatura precisa começar, sem dúvida, com a criança pequena, de modo contínuo e atrativo, pois só desta forma ela se motivará e continuará a estreitar vínculos com o amplo universo literário pela vida afora, mesmo depois dos momentos de escolarização. Sendo assim, desenvolverá, simultaneamente, os principios básicos da cidadania, da cooperação e das relações humanas de forma geral, vivenciados no contato com diversas histórias - representativas da história de vida da humanidade - que constituem a trajetória das relações humanas desde há muito tempo, ou seja, a própria essência do tema transversal 'Ética', em sua mais pura concepção.

Os exemplos apresentados representam apenas um recorte ilustrativo que poderá ser aprofundado na leitura do documento acima discutido em sua integra. $O$ objetivo desta pequena mostra é o de ressaltar que já existem possíveis caminhos - e a literatura se constitui como o primordial - que indicam, de maneira clara e evidente, a importância de se oportunizar à criança a vivência de situações discutidas e refletidas a partir dos principios da Ética, desde a mais tenra idade da criança, mesmo em se tratando de um assunto dialético e polêmico, principalmente, para o momento primeiro de sua formação que se alicerça na Educação Infantil.

Sendo assim, é necessário que se compreenda o processo de desenvolvimento moral da criança, a fim de que possamos auxiliá-la na trajetória de construção de sua moralidade, por meio de vivências significativas para o alicerçamento dos principios da Ética e dos Valores Humanos indispensáveis para a sua formação integral

\subsection{O desenvolvimento moral da criança}

'Qualquer um poderia me perguntar com que direito eu me permito transgredir algumas leis e obedecer outras.

A resposta é esta: há dois tipos de leis - as justas e as injustas; a pessoa tem uma responsabilidade legal nāo somente legal, mas também moral, de obedecer às leis justas e desobedecer às injustas. Uma lei injusta é um código que um grupo mais numeroso ou mais potente impõe a um grupo menor, mas que não é considerado válido por si esmo.

Essa é a diferença legalizada.'

Martin Luther King

Partindo-se do princípio de que para o convivio em grupo é necessário o estabelecimento de parâmetros e regras universais de convivência que garantam a todos o direito de terem respeitados os principios básicos de sua cidadania, 0 direito de ir e vir sem prejudicar e sem ser prejudicado, fica para nós, educadores, o 
grande desafio de vivenciar estas importantes reflexões com a criança pequena, tendo em vista os momentos especificos de seu desenvolvimento moral.

Considerando-se que a legitimação de regras é algo a ser desenvolvido e construído por vivência, é necessário refletirmos sobre o assunto de maneira cautelosa. Tomaremos, como exemplo, as discussões do psicólogo suíço Jean Piaget (1896 - 1980) que apresenta uma das teorias mais complexas sobre o desenvolvimento cognitivo.

Por entender que a moralidade inicia-se a partir do respeito que adquirimos às regras do meio, é essencial estudarmos como as crianças adquirem e constroem esse respeito e de que forma ele é

Piaget traz-nos uma grande contribuição para a reflexão sobre a situação de vivência das regras pelas crianças, a partir de seu trabalho de observação feito por meio de um jogo conhecido no mundo inteiro - o jogo das bolinhas de gude. Observando as crianças de diferentes idades, jogando com elas e conversando a respeito das regras do jogo - quais são, por que usá-las, de onde vêm e sobre a possibilidade de modificá-las — , percebeu que dois aspectos fazem parte da concepção infantil sobre as regras: a prática delas e a consciência a seu respeito.

Em relação à prática das regras, foram descobertos quatro estágios a partir dos quais, segundo PIAGET (1996), as crianças usam as regras para si mesmas e para os outros em situação de jogo:

- "(..) crianças bem pequenas, até mais ou menos 3 anos, jogam em função de seu próprio desejo, divertem-se sozinhas, fazem gestos repetitivos e regulares ao brincar, mas este brincar é totalmente individual e nada tem a ver com o jogo de bolinhas em si: é o estágio das regras motoras e não sociais ou individuais;

- crianças entre 3 a 6 anos (todas as idades são médias prováveis, não exatas) parecem jogar como os grandes; imitam-nos fazendo muitas das coisas que aqueles fazem ao jogar. No entanto, olhando de perto, veremos que estas crianças mudam as regras a bel prazer toda vez que isto for interessante para elas. Piaget chamou este estágio de egocêntrico: cada criança joga por si, embora todos estejam imitando os mais velhos. Essas crianças não se dão ao trabalho de combinar como vão jogar, não codificam as regras entre si; elas saem jogando e pronto!

- entre 7 a 10 anos, aproximadamente, as crianças passam a usar de fato as regras entre si para organizarem como jogar. As crianças começam a descobrir que é preciso ter um conjunto de regras igual para todos, senão o jogo torna-se impossivel; porém, ainda não combinam muito bem, antes do jogo, como vão jogar. Este é o estágio de Cooperação nascente;

- como último estágio, após 11 anos (sempre mais ou menos), as crianças passam a codificar as regras do jogo. Às vezes, o tempo gasto combinando como jogar, com que regras, é maior que aquele do próprio jogo. As partidas são regulamentadas em minúcias onde todos os casos possiveis de acontecer são discutidos para se construirem regras adequadas. As crianças passam a ter interesse pelas regras em si, buscando construi-las as mais justas e completas. (...)" (pp.43-4)

Em relação à consciência de regras, ainda segundo a observação de PIAGET (1996), destacam-se os aspectos relacionados à compreensão que as crianças têm sobre as mesmas: o que são, para que servem, de onde vêm, quem as 
faz, se podem ser mudadas... Nesta observação encontram-se três estágios significativos

- "(..) crianças pequenas (até 3 anos aproximadamente), que estão no $1^{\circ}$ estágio da prática de regras, não têm ainda uma compreensão das mesmas. Enquanto jogam como querem não têm consciência da obrigatoriedade de um certo modo de jogar, assim, a regra não é coercitiva ou porque é puramente motora (não há consciência) ou porque é encarada como exemplo interessante, apenas;

- numa segunda etapa as crianças (entre 3 a 8, 9 anos) começam a ver a regra como 'uma coisa sagrada e obrigatória'. As regras são colocadas como sendo tão reais como qualquer outro fato da natureza e são consideradas imutáveis! Toda modificação nas regras é tida como uma transgressão, um crime (...);

- finalmente aparece o terceiro estágio de consciência das regras: as crianças passam a considerá-las como algo elaborado pelo grupo e que serve na medida em que foi combinado por todos; consideram que é importante obedecer a regra, não porque ela é sagrada, mas porque com ela é possivel todos jogarem em iguais condições. Para elas as regras podem ser modificadas desde que todo o grupo veja necessidade disso e chegue a um acordo sobre a nova regra. É nesta fase que a regra passa a ser fruto de sua atividade racional e social: há razões, no jogo para cada regra e para que uma seja melhor que outra, e as regras servem a todos e vêm de todos! (...)

Portanto: primeiro é fazer para depois compreender! (...)" (pp.48-9)

Percebemos, portanto, que, segundo a concepção piagetiana, construida a partir de situações vivenciadas pela criança no grupo diante das regras do jogo, ela apenas descobre o verdadeiro sentido das regras, ou seja, passa a ter consciência sobre elas, quando começa a praticá-las em situações de cooperação grupal, pgis enquanto estiver imitando o mais velho, ainda não terá compreensão do que é uma regra. Esta compreensão só virá quando a regra passar a ser produto das relações entre iguais

Nesse sentido, é fundamental o auxilio do professor/educador e da escola com uma proposta pedagógica ampla e abrangente que considere primordialmente - significado da vivência de valores morais pelas crianças, oferecendo situaçães que desenvolvam a cooperação no trabalho em grupo, gerando uma real consciência sobre a importância das regras - e não apenas a obediência a elas por uma simples imitação ao adulto - , propiciando respeito ao direito do outro, assim como para recebendo o respeito que também lhe é de direito

É necessário que a criança perceba e considere as regras como elemento básico para o convívio social, capaz de favorecer a igualdade de direitos e deveres nas experiências compartilhadas por todos de forma justa e benéfica a cada um dos participantes do grande jogo da convivência humana. Se buscarmos conseguir isto, estaremos também buscando calcar os alicerces da Ética e dos Valores Humanos em nossas crianças, em nossos alunos.

Para atingirmos tal intento, precisamos, ao mesmo tempo, respeitar o momento em que se encontra a criança no processo de evolução de seu desenvolvimento moral, já que cada nivel apresenta caracteristicas próprias e peculiares que precisam ser consideradas pelo professor/educador na dosagem de 
desafios que oferece à criança diante de determinadas situações-problema propostas em convivência com o grupo.

No oferecimento de situações-problema à criança, que visem ao auxilio em seu desenvolvimento moral, é preciso atentar-se para não ficar aquém das possibilidades da criança - causando a desmotivação infantil — , nem tampouco ultrapassar suas reais capacidades de apreensão sobre regras, valores e noções muito complexas para a compreensão da criança, indo além do que the é possível em determinado momento de sua trajetória - , causando a sensação de incapacidade ou não correspondência às expectativas do adulto — , sendo prejudicada em sua auto-estima e, também, possivelmente, nas relações interpessoais.

Em uma colocação ilustrativa de PIAGET (1996) sobre as discussões acima apresentadas, podemos perceber a importância de respeitarmos o momento em que se encontra a criança no processo de seu desenvolvimento moral e na consciência que tem sobre as regras e parâmetros de convivio no grupo, a fim de que, aos poucos, possamos realmente auxiliá-las a encontrar na moral, o verdadeiro sentido para a convivência prazerosa e justa em qualquer situação grupal

"(.) As crianças são heterônomas quando fazem uso imitativo das regras e quando as consideram sagradas, pois vindas da tradição e imutáveis...

As crianças são autônomas quando fazem uso racional e social das regras, e quando as consideram produtos do e para o grupo.

A autonomia moral, que para Kant reside na vontade do homem de escolber submeter-se a leis mais 'universalizantes', aparece sendo construida em crianças, passo a passo, que chegam a decidir as regras a que se submeterão no grupo.

A 'universalização' na moral começa, portanto, com a reciprocidade no grupo! Ou seja, aprendendo a fazer em grupos, cada vez maiores, aquilo que é bom para nós, começamos a fazer, no mundo, o que é bom para a humanidade!(...)" (p.46)

Os estudos de Piaget muito tem-nos auxiliado a compreender como se processa o desenvolvimento moral da criança e, a partir de muitas de suas descobertas é possivel aprimorar nossa atuação como educadores, tendo como base o conhecimento de muitas peculiaridades inerentes ao desenvolvimento infantil.

Diante destas reflexões, podemos pensar na função da escola que deve solidificar o tratamento do tema Ética, partindo basicamente do oferecimento à criança de uma verdadeira Educação Moral, capaz de levá-la a uma construção interior de principios universais e norteadores para o seu convívio social.

Mas, o que seria a aplicação de uma Educação Moral oferecida pela escola à criança como elemento desencadeador de principios básicos de convivêmcia arraigados na Ética?

Estaremos, nós, educadores, preparados para enfrentar este grande, mas necessário, desafio para o desenvolvimento integral de nossos alunos - e por que não dizer também nosso? 
Estas questões merecem uma discussão cautelosa e consistente, pois se trata de algo de extrema importância para o aprimoramento das relaçōes intra e interpessoais - docentes e discentes - e para a consecução de nossas metas educacionais de maneira ampla e significativa.

\title{
5.3. A Educação Moral no contexto escolar
}

\author{
A participaçāo dos alunos tem sido um objetjvo \\ e um meio recorrente em todas as propostas \\ progressivas de educação civica, social e moral. \\ Pensamos que a participação democrática \\ de professores e alunos em foro de diálogos, \\ em que se apresentam \\ os problemas de convivência e trabalho, \\ è o pano de fundo imprescindivel \\ de qualquer atividade de educação mopal \\ e em si mesmo uma fonte privilegiada \\ de experiências morais significativps.
} Josep Maria Puig

Quando se ouve falar, atualmente, em Educação Moral, faz-se, geralmente, uma associação, muitas vezes até um pouco pejorativa, com uma suposta forma. de aprendizagem resultante de formas educativas tradicionais, que pregavam o excesso de patriotismo ou noções de civismo exageradas e sem uma consistente reflexão sobre o assunto, apenas por decoração ou memorização mecânica.

Este tabu precisa ser revisto, pois a concepção de Educação Moral não se refere à imposição heterônoma de valores e normas.

Nesse sentido, PUIG (1998a), com base um seu programa de Educação Moral, pode auxiliar-nos a clarificar considerações sobre sua essência:

"Pensamos que a educação moral deve converter-se em um âmbito de reflexão individual e coletiva que permita elaborar racional e autonomamente principios que ajudem a defrontar-se criticamente com realidades como a violência, a tortura ou a guerra. A educação moral deve ajudar a analisar criticamente a realidade cotidiana e as normas sociomorais vigentes, de modo que contribua para idealizar formas mais justas e adequadas de convivência. Também pretende aproximar os educandos de condutas e hábitos de convivência mais coerentes com os principios e nomas que vão construindo. $E$, finalmente, a educação moral quer formar hábitos de convivência que reforcem valores com a justiça, a solidariedade, a cooperação ou o cuidado com os demais.(...)" (p.15)

Todas as colocações de Puig reiteram nossas discussões anteriores sobre a importância de se vivenciar situaçōes de convivência baseadas nos principios 
gerais e universalizantes da Ética, a fim de as mesmas sejam capazes de formar hábitos de convivio com valor e significado indiscutiveis para a criança, desde a sua formação inicial

Mas para que estas situações desencadeiem hábitos favoráveis ao relacionamento social, o que podemos pensar em termos de uma Educação Moral abrangente que propicie estas condições de convivência ética?

PUIG (1998a) auxilia-nos, neste sentido, partindo do principio de que a moral não pode e nem deve ter um caráter impositivo, mas sim reflexivo e de. uma significativa construção moral, que se fará no dia-a-dia, caso contrário não estaremos colaborando com os educandos para o desenvolvimento de todas as capacidades que intervêm no juizo e na ação moral diante de situações problematizadoras e de conflito que venham a enfrentar em suas vidas.

Somente a partir da reflexão desencadeada nas vivências dos educandos é que estes serão capazes de se orientar de forma racional e autônoma sempre que estiverem diante da responsabilidade de assumirem determinadas posiçōes no que se refere aos conflitos de valor

Diante destas discussões, PUIG (1998a) coloca-nos algumas quesiones bastante pertinentes no tocante à Educação Moral:

"(...) A educação moral não tem motivo para ser necessariamente uma imposição heterônoma de valores e normas de conduta, mas tampouco se reduz à aquisição de habilidades pessoais para adotar decisões puramente subjetivas. A educação moral pode ser um âmbito de reflexão que ajude a:

- Detectar e criticar os aspectos injustos da realidade cotidiana e das normas sociais vigentes

- Construir formas de vida mais justas, tanto nos âmbitos interpessoais como nos coletivos.

- Elaborar autônoma, racional e dialogicamente principios de valor que ajudem a julgar criticamente a realidade

- Conseguir que os jovens façam aqueles tipos de comportamentos coerentes com os principios e normas que pessoalmente construiram.

- Fazer com que adquiram também aquelas normas a sociedade, de modo democrático e visando à justiça, Ihes deu." (p.17)

A Educação Moral tem caráter abrangente e universalizante, não podendo ser considerada sob qualquer perspectiva individualista ou apenas subjetiva, já que sua essência baseia-se em uma construção reflexiva que se edifica a partir_de formas de convivência pessoal e coletiva simultanemante. Ela implica em uma decisão assertiva de se mudar o rumo dos acontecimentos, transformando-os de maneira significativa com base no respeito à autonomia pessoal e no diálogo fundamentado nas regras básicas de convivência humana - alicerçada na justiça e na igualdade dos deveres e direitos de todos indistintamente.

$\mathrm{Na}$ verdade, não podemos pensar na Educação Moral como uma tábua de salvação capaz de resolver, de imediato, todas as mazelas sociais que nos cercam, impondo regras, critérios de valor totalmente absolutos, pois os modelos de normas 
de conduta indiscutíveis e imodificáveis, colocados de maneira autoritária, nāo poderão auxiliar em uma verdadeira mudança interior.

Em uma reflexão sobre os processos psicológicos presentes na legitimação dos valores e regras morais, os PCNs (1996), ilustram de modo esclarecedor alguns princípios básicos relacionados à afetividade e a racionalidade.

Em se tratando da afetividade, podemos dizer que toda regra moral legitimada, aparecendo como obrigação, precisa ter conteúdos significativos que toquem em alguma medida nossa sensibilidade, ou melhor dizendo, que nos pareçam desejáveis, caso contrário, não será seguida por nossa opção ou escolha, mas apenas em cumprimento a algo imposto que, se não obedecido, nos trará um castigo. Sendo assim, as regras morais devem relacionar-se à idéia de ser possivel alcançar, através delas, uma vida boa, justa, significativa, capaz de realizar um projeto de felicidade que seja válido para todos por meio da conquista de cada um do respeito de si.

Na verdade, cada um de nós procura imagens boas de si mesmo, na tentativa de se ver como valor positivo e, portanto, apreciado e aceito pelos outros, ou seja, o respeito de si depende do fato de ser respeitado pelo outro.

Dentro desta perspectiva apresentada nos PCNs (1996), a humilhação forma indesejável, mas infelizmente não rara nas relações humanas - não auxilia de maneira alguma no desenvolvimento do respeito de si, pois a pessoa não pode se basear no respeito que o outro lhe deveria direcionar; portanto, não existe aqui o projeto de felicidade, o bem-estar psicológico que se precisa sentir para o cumprimento das regras, e, assim, diante da humilhação, estas não serão respeitadas. Talvez sejam cumpridas pelo medo do castigo aplicado em face à sua não obediência, mas não haverá, com certeza, a opção de segui-las porque tocaram a sensibilidade das pessoas:

"(...) As crianças conhecem este mecanismo psicológico. Uma delas, perguntada a respeito dos efeitos da humilhação, afirmou que um aluno assim castigado teria mais chances de reincidir no erro; ele pensaria consigo mesmo: 'já que estou danado mesmo, posso fazer o que quiser.....) A dimensão afetiva da legitimação dos valores e regras morais passa, de um lado, por identificá-los como coerentes com a realização de diversos projetos de vida e, de outro, pela internalização destes valores e regras enquanto valor pessoal que se procura resguardar para permanecer respeitando a si próprio. Assim, 0 respeito de si articula, no âmago de cada um, a busca da realização de projeto de vida pessoais e o respeito pelas regras coerentes com tal realização." (p. 61-2)

Pelas colocações anteriores, percebemos que a dimensão afetiva constituise como um elemento basilar na formaçāo do ser em relação aos valores, normas e regras que construirá para sua vida dentro e fora do contexto escolar.

Dessa forma, o grande desafio da escola é o de oportunizar situaçōes de convivência capazes de desenvolver o 'respeito de si' em cada criança e, também, pensar na realização deste trabalho com a familia, que se apresenta como ponte de ligação entre a criança e a escola.

Assim, toda proposta, que se pretenda integral e coesa, jamais poderá apresentar à criança universos divergentes sobre as situações em questão. Sem a união de esforços entre a escola e a família em busca de um objetivo comum, que é 
- aprimoramento da criança, em todos os aspectos, o trabalho de concepções fragmentadas e sem parceria, poderá deixar de ser bem-sucedido.

Ainda, refletindo sobre a legitimação das regras morais, além do investimento afetivo, os PCNs (1996), apresentam um segundo elemento importante neste sentido: a racionalidade

Este elemento decorre de pelo menos três razões a serem consideradas sobre sua importância na legitimação de regras morais:

- agir segundo regras morais implica fazer uma escolha. Isto, por sua vez, implica adotar critérios de opçāo baseados na responsabilidade e na liberdade e juizo de escolha a ser feita de maneira racional;

- pensar racionalmente sobre a moralidade, a fim de não cometer atos impensados segundo a falta de reflexão sobre os valores;

- utilizar a racionalidade para dialogar, resolver conflitos através da comunicação, do uso da palavra, da expressão clara que permite se fazer entender e ser entendido

$\mathrm{Na}$ verdade, todas as consideraçōes apresentadas sobre a necessidade da racionalidade na legitimaçāo das regras decorrem do fato de corresponderem a capacidades essencialmente resultantes do pleno exercicio da inteligência.

Podemos concluir que tanto a afetividade quanto a racionalidade são fatores indispensáveis para a construção dos alicerces relativos à legitimação de regras. Sabemos que ambas não são inatas, pois se desenvolvem a partir das interações sociais e, neste aspecto, surge o papel fundamental da escola, oferecendo oportunidades e vivências capazes de auxiliar a criança a construir suas noções sobre regras, normas e valores imprescindiveis para a sua formação integral:

"(...) Podemos, na busca de maior clareza desta exposição, estabelecer desde já duas decorrências centrais para a educação moral. São elas

- A escola deve ser um lugar onde cada aluno encontra a possibilidade de se instrumentalizar para a realização de seus projetos; por isso, a qualidade do ensino é condição necessánia à formação moral de seus alunos. Se a escola não promove um ensino de boa qualidade, ela condena seus alunos a sérias dificuldades futuras na vida $e$, decorrentemente, a que vejam seus projetos de vida frustados.

- Ao lado do trabalho de ensino, deve organizar o convivio dentro da escola de maneira que os conceitos de justiça, respeito e solidariedade sejam vivificados e compreendidos pelos alunos como aliados à perspectiva de uma 'vida boa'. Desta forma, não somente os alunos perceberão que estes valores e as regras decorrentes são coerentes com seus projetos de felicidade como serão integrados às suas personalidades: respeitar-seão pelo fato de respeitá-los. (...)" (PCNs, 1996: pp.12-3)

Em relação aos caminhos que a escola pode tomar para a aplicação de um programa curricular que priorize a Educação Moral da criança, por todos os benefícios até aqui justificados para a sua formação, é possivel pensarmos em um currículo baseado na Educação em Valores Humanos, capaz de oferecer à criança oportunidades de vivência que the oportunize a reflexão e a aplicação de experiências responsáveis pelo seu desenvolvimento moral, ou melhor dizendo, por sua formação integral. 


\subsection{Educação em Valores Humanos}

- Torna-se essencial reconhecer

que os valores não são estáticos,

e sim que estão submetidos a sucessivas modificaçães

provocadas pelas distintas experiências

que vive cada pessoa e pela relação

que estabelece com seu meio sociocultural.(..)

Pode-se contribuir para alcançar valores pessoais de diversas formas.'

Josep Maria Puig

Pensar em Valores Humanos associa-se às idéias discutidas anteriormente sobre as questōes culturais relativas às regras, normas e procedimentos éticomorais, de cada individuo, inserido em diferentes meios e contextos sociais, que por sua vez podem privilegiar costumes e hábitos estranhos para alguns grupos e perfeitamente normais e aceitáveis para outros.

Como exemplo podemos citar a cultura indigena que apresenta para os adolescentes 'testes' de resistência física, representando 'rituais, ou ritos de passagem' indispensáveis para a transposição à vida adulta. Em alguns grupos indigenas, por exemplo, os rapazes têm de se submeter a escoriações feitas na pele, às picadas de abelhas e outros insetos ... As moças precisam ficar isoladas da tribo, por dias e dias, antes de serem consideradas adultas e preparadas para o casamento

Para muitas pessoas de outras civilizações, com características culturais diferentes, os testes ligados aos ritos indigenas parecem cruéis e desumanos; no entanto, para os indigenas, constituem-se como padrões normais de vida e, talv£z se os questionássemos sobre a nossa conduta de vida, responderiam que os nossos procedimentos culturais, aliados na maioria das vezes ao 'poder de ter' $e$, mais raramente ao 'poder de ser', é que seriam, segundo os preceitos indígenas, considerados muito estranhøs...

Por todas as discussões já apresentadas até este ponto de nossas reflexões, consideramos que as regras, critérios, normas de convivência e os valores precisam corresponder, de forma 'universalizante', a padrões de conduta que, independentemente de peculiaridades culturais, precisam adequar-se, segundo critérios éticos generalizantes, que abranjam todas as pessoas do mungo, nas considerações ao que é comum para o bem-estar de todos e, portanto, para a humanigade.

Nesse sentido, cabe, aqui, começarmos a verificar algumas reflexp̄es importantes sobre a questão da formação de Valores Humanos e suas implicações.

MARTINELLI (1999) oferece-nos esclarecimentos relevantes e sugestões de trabalho sobre esta discussão, começando por definir, na essência, o significado dos Valores Humanos: 


\section{(...) Que são Valores Humanos?}

São os principios que fundamentam a consciência humana. Eles estão presentes em todas as religiões e filosofias, independentemente de raça, sexo ou cultura. São inerentes à condição humana. Os valores humanos dignificam a conduta humana $e$ ampliam a capacidade de percepção do ser como consciência luminosa que tem no pensamento e nos sentimentos sua manifestação palpável e aferivel. Eles unificam e libertam as pessoas da pequenez do individualismo, enaltecem a condição humana $e$ dissolvem preconceitos e diferenças. " (p.17)

Sendo considerados como fatores indispensáveis à formação humana no enaltecimento de sua ação sobre o mundo - energia pulsante em todos os seres humanos -, os Valores Humanos estão presentes e vivos em todo pensamento humano e por determinar o comportamento e orientar a inteligência e a criatividade, precisam ser vivenciados a cada momento por todos, e a escola assume um papel de grande responsabilidade neste sentido, pois pode oportunizar experiências capazes de auxiliar os educandos na clarificação de valores através da reflexão e vivência cotidiana sobre os mesmos

\section{Segundo MARTINELLI (1999)}

"(...) Na escola, estão presentes na apreciação e assimilação do conhecimento de todos os conteúdos a serem ensinados. Os valores integram o conhecimento, a família, a escola e a vida em sociedade. Vinculam o ensinamento ministrado na escola às circunstâncias da vida, construindo uma consciência da ética e da estética do bem. Os valores não devem ser encarados como algo abstrato ou estanque, nem como um código de conduta imposto de fora para dentro. A educação em valores na familia e na escola deverá incrementar a capacidade de discernimento dos alunos e conscientizá-los da importância das suas escolhas. Assim. a educação consolida os valores e virtudes já existentes nos alunos e incentiva a superação de erros e defeitos." (p.21)

$\mathrm{Na}$ verdade, todos nós possuimos valores. Uma educação em Valores Humanos seria, assim, pautada na vivência e reflexão sobre situações diversas, conscientizando o educando a respeito da importância ética de suas escolhas na vida, fazendo-o sentir-se capaz de discernir, com clareza, em relação ao comportamento adotado por ele como responsável pelo seu próprio bem-estar e para o bem-estar geral da humanidade.

Não se trata de doutrinação ou busca obsessiva e desenfreada do bem, mas de discutir sobre os erros e defeitos, os acertos e as qualidades inerentes a todos e saber como lidar com estas pulsões dialéticas e dinámicas que existem, concomitantemente, em todo ser humano. Conhecendo a si mesmo, o educando poderá lidar melhor com súas ações e reaçōes e, conseqüentemente, consegujrá lidar melhor com os outros, colaborando, assim, de maneira ética, para a evolução da humanidade.

A educação em Valores Humanos já vem sendo pensada há muito tempo por vários educadores, pesquisadores e colaboradores para a evolução do ser humano de maneira integra e integral. O precursor responsável pela criação do Programa de Educação em Valores Humanos foi Sathyia Sai Baba - o mais 
importante líder espiritual da Índia, nascido há 73 anos na aldeia de Puttaparthi, hoje um dos maiores centros de peregrinação do mundo.

Sai Baba é também considerado um excepcional educador de mentes e almas. Há trinta anos atrás, criou e introduziu como uma idéia-semente em sua aldeia, o Programa de Educação em Valores Humanos (PEVH).

A idéia-semente de Sai Baba floresceu e se expandiu no mundo inteiro. $\mathrm{O}$ programa iniciado pelo educador de almas ampliou-se e, atualmente, constitui-se em um complexo educacional que compreende desde escolas de ensino fundamental e médio até universidades, estabelecendo a integração da tecnologia de ponta com a espiritualidade, no casamento da ciência com a religiosidade.

O PEVH proposto por Sai Baba integra filosofias e técnicas educacionais, visando à criação de uma nova realidade, ou seja, uma ordem social mais humana e justa criada a partir da unificação do conhecimento.

MARTINELLI (1999) informa-nos quais são as metas do PEVH, com base nas concepções de seu mentor e criador:

- "(...)Conduzir o aluno ao caminho do autoconhecimento e auto-realização mediante o desenvolvimento integrado da personalidade e da espiritualidade, independentemente de religião, seita. doutrina ou credo.

- Incentivar o espirito de cooperação, a criatividade, o respeito às diferenças e a reverência e o amor pelos seres humanos e pela natureza.

- Conscientizar os alunos de seus e capacidades e estimulá-los a empregá-los com dignidade para o bem da comunidade.

- Libertar as pessoas do medo e culpa impostos culturalmente e mostrar que só alcançamos a liberdade e a felicidade e diminuimos os conflitos quando não fazemos da nossa personalidade o centro, mas parte da vida.

- Mostrar que o poder está na lisura do caráter e na grandeza do espirito. Ensinar que a sabedoria está em aceitar as tribulações e dificuldades como forma de ensinamento. Viver a vida com honestidade, serenidade, integridade e compaixão.

- Facilitar a percepção da origem cósmica do ser humano e a compreensão da importância das necessidades básicas e coisas materiais. Preconizar o uso do dinheiro para o bem-estar social, como gerador de possibilidades e não como fonte de poder.

- Despertar nos alunos a consciência de que eles serão as lideranças que estabelecerão os moldes da sociedade futura e o destino do país.

- Vivenciar o amor como pilar de sustentação da fraternidade humana e da sobrevivência da espécie e do planeta e a paz como valorização da vida. " (pp. 22-3)

As metas do PEVH visam à formação integral e integra do aluno. $O$ educando precisa refletir sobre sua importância na construção do bem-estar da humanidade, perceber e vivenciar os principios básicos da Ética, experienciando no seu cotidiano os valores imprescindiveis à preservação do homem na história da humanidade, tendo o amor como pólo de sustentação de todas as relaçōes. 
Dessa forma, o programa não apresenta qualquer conotação religiosa ou doutrinária de uma filosofia ou seita em particular. Ao contrário, propõe uma educação universalista, humanista e espiritual, baseada no resgate dos valores humanos presentes em todas as religiōes, filosofias e culturas.

Busca a formação de uma sociedade planetária a partir da conscientizaçøo e prática de valores humanos. Ao nos isolarmos uns dos outros, por decorrência da competição, da falta de compaixão e de outros antivalores não condizentes ao bemestar da humanidade, conseqüentemente, nos afastamos, também, do divino. $O$ resgate do sagrado, aquele que não seja cultuado apenas em templos, mas vivenciado de forma consciente e inerente ao nosso ser, exige que saiamos de um pensar e viver subjetivo e egocêntrico para a busca de um bem maior coletivo e universal

No PEVH, portanto, o professor/educador tem um papel de extrema importância, pois será o referencial de modelo dos valores, podendo utilizar-se da narrativa de contos e vidas de pessoas, dando demonstrações práticas da importância de viver os valores para facilitar a sua conscientização e assimilação.

Sob esta perspectiva, a literatura pode contribuir de maneira inigualáyel para o PEVH. através da apresentação de personagens e histórias que levem o educando a refletir, a comparar e a discernir sobre sua própria conduta, a partir da vida e do comportamento das personagens das histórias.

$\mathrm{Na}$ discussão com os alunos, é importante abordar as situações cotidianas, positivas, ou não, estimulando a reflexão e a formação de conceitos e princípios éticos Os valores sociais compartilhados, os valores de sobrevivência e os valores espirituais, assim como os antivalores - racismo, fanatismo religioso ou ideológico, egocentrismo, orgulho, ganância etc - devem ser informados e apresentados na exposição do assunto discutido para o reconhecimento e a compreensão geral dos educandos sobre os valores humanos e os antivalores, na abrangência maior de sua real existência.

$\mathrm{Na}$ reflexão realizada com os educandos sobre ao valores humanos e os antivalores, uma sugestão possivel - para fazê-los compreender que os valores humanos não são privilégios apenas de santos e grandes mestres, mas de todos nós -, é pedir aos alunos para que apresentem uma palavra ou enunciado que signifique o contrário de um valor discutido. A partir desse jogo dialético, os educandos sentir-se-ão capazes de perceber os valores e os antivalores e de discernir sobre os benefícios que a vivência dos valores humanos podem trazer para a humanidade, sendo deles a responsabilidade desta escolha.

A metodologia do PEVH integra as conquistas no campo da educação, pois representa a comunhão de várias filosofias educacionais, através do cultivo da integração, do autoconhecimento, do contato e da convivência dos seres humanos entre si e com a natureza de maneira positiva e benéfica a todos sem distinção.

A escola em seu papel educativo, e todos de modo geral, somos coresponsáveis na tarefa de compartilhar o que existe de bom. Sendo assim, as propostas educacionais devem oferecer experiências ricas e variadas aos educandos, pois isto auxiliará na construção de uma nova ordem social onde a ética será o sustentáculo das relações humanas. 
O PEVH não deve ser encarado como uma disciplina a mais no currículo da escola, pois apresenta caráter transdisciplinar, permeando todas as áreas do saber de modo contínuo e ininterrupto, (re)significando a vida dos educandos e ultrapassando, ainda, os muros da escola.

\section{Para D'Ambrosio (1999):}

"(...) A transdisciplinaridade é essencialmente o reconhecimento de que tudo está em permanente transformação. Desde que haja vida, tudo está em permanente transformação. Esse é o seu grande desafio. Nos temas transversais ou no sistema de valores humanos, como quisermos chamar, está colocado intrinsecamente a esse pensar o fato de que tudo está se transformando permanentemente. (...) A transdisciplinaridade transforma a arrogância do saber na humildade da busca. "(..) (pp.43-4)

Segundo a contribuição D' Ambrosio (1999), em uma analogia à transdisciplinaridade do $\mathrm{PEVH}$, percebemos que o objetivo básico do programa pode ser associado ao real sentido da busca pelo aprimoramento do ser humamo. Trata-se de uma proposta educacional que visa mostrar a inter-relaçāo dos temas ou conteúdos ensinados com situações vivenciadas e enfrentadas, no dia-a-dia, do educando. a fim de que possa compreender as relaçōes entre 'o que está aprendendo' em determinada área de estudo e 'o significado disto' para sua viga, avaliando o seu comportamento de forma consciente e sentindo-se responsável no que se refere às escolhas que fará a partir destas relações.

MARTINELLI (1999) oferece-nos alguns exemplos de possiveis aplicações do PEVH na escola, partindo da premissa de que os valores devem ser discutidos e enfocados de maneira prática e, para tal, sugere uma abordagem a partir de atividades como oficinas pedagógicas, onde o professor/educador - de qualquer disciplina ou área de conhecimento - deverá ser bastante criativo e perspicaz para desenvolver o trabalho com seus alunos de maneira significativa para ambos:

- "(..)Procure encontrar analogias e metáforas para a observação dos valores nas disciplinas ensinadas.

- Ao trabalhar a matemática, mostre a ligação entre duas ações e suas conseqüências, a relação entre discernimento, o equilibrio emocional e a economia de esforços na solução de problemas.

- Quimica: na pesagem de sais e decupagem de elementos, ressalte a importância do justo peso e medida que damos às coisas e situações, a sensibilidade e a imparcialidade como faculdades que facilitam a nossa harmonia interior e exterior, etc. "(..) (p.25)

A partir das relações que o educando estabelece entre o que aprende 9 a importancia disto para sua vida, ele passa a valorizar mais a possibilidade real de ampliação de seus conhecimentos, beneficiando a si próprio e aos outros. Deste momento em diante, conseguirá ir aprofundando os princípios da Ética em sua vida.

O PEVH considera que a Ética constitui-se como a bagagem de virtudes contida no intimo do ser humano e uma postura consciente diante das relações consigo, com os demais, com a natureza e com a universalidade de expressões culturais da humanidade. A ética é trabalhada na descoberta do manancial de 
virtudes latente em cada criança pela autodescoberta, pela reverência e pelo respeito para com as diferenças.

Em um momento da história em que ouvimos falar em tanta violência e dificuldade nas relaçōes humanas, o PEVH apresenta fortes razões para que seja aplicado nas escolas de maneira compromissada, sistemática e emergencial.

Precisamos, como educadores, resgatar o real sentido de nosso papel de formadores, transformadores e de humildes aprendizes que buscam melhores caminhos para o aprimoramento de nossa atuação docente, pois só assim conseguiremos auxiliar nossos alunos

A importância de um programa que priorize a formação de Valores Humanos justifica-se pela necessidade de se trabalhar com aspectos do interesse coletivo e que correspondam às expectativas mais latentes do ser na sua busca de amor, de consideração, de afetividade, enfim de emoçōes, de sentimentos, ou melhor dizendo, de sustentáculos que dêem sentido para sua vida e para a vida de tadas as pessoas indistintamente.

MARTINELLI (1999) ilustra a importância do PEVH enfocando a riqueza que constitui a função de educar:

"(..) O programa focaliza cuidadosamente diferentes aspectos da função de educar. mas sobretudo acentua a afetividade, o relacionamento amoroso entre educador e educando. Os sentimentos e instituições são primordiais na condução do educador. Os elementos psiquicos e espinituais enriquecem o processo de lecionar, desenvolvem a cnatividade e a capacidade de amar e refletir e criar. A pedagogia do amor reconhece o espirito como o sustentáculo e a raiz da personalidade e o amor como energia primordial e inesgotável que move o mundo. Educar em valores com amor aponta soluções para a transformação de uma sociedade que é infeliz e desarmônica basicamente porque se tornou incapaz de amar" (p.35)

É evidente que a escola não pode e nem conseguirá ser guardiā onipresente e onipotente do aluno em todas as situações, nem tampouco o professor/educador conseguirá ser juiz de todos os atos e pensamentos desse aluno; no entanto, é papel da escola e da familia resgatar a identidade da criança, mediante a conscientização e a reflexão sobre sua existência e sua atuação no mundo

O aluno/educando precisa sentir-se amado, respeitado e valorizado pela familia e pela escola. Em nosso papel de educadores precisamos contribuir para que a escola seja um lugar prazeroso e agradável, capaz de atrair o aluno e garantir sua permanência na escola, aprofundando suas vivências e reflexões sobre os Valores Humanos e sua responsabilidade como multiplicadores dos mesmos. Para tal, é necessário haver uma parceria entre educador/educando, a fim de que construam juntos a alegria de aprender com base no entusiasmo alimentado pelo diálogo e pelo amor.

Por apresentar uma proposta coerente, consistente e bem fundamentada nos principios da Ética como elemento vital nas relações humanas e na construção do conhecimento do ser de maneira integral e íntegra, vários paises do mundo já adotaram o PEVH como modelo curricular implementado em seus sistemas educacionais conforme elucida MARTINELLI (1999): 
"(..)O programa é aplicado há mais de trinta anos em escolas de cerca de 130 paises, como Itália, Alemanha, Inglaterra, Estados Unidos, Espanha e Brasil, Colômbia, Venezuela, México, Uruguai e Argentina na América do Sul, que divulgam e investem na educação em valores humanos embora não oficialmente, mas por ações de iniciativa privada. (...) No Brasil já existem escolas que aplicam essa metodologia, como o Grupo Sedes Sapientiae, de Santos (SP), e a escola Holos, de Patos de Minas (MG). Em Peirópolis, Uberaba (MG), há um projeto para a construção de uma escola de ensino fundamental com os padrões e principios do Programa de Educação em Valores Humanos. No Rio de Janeiro (bairro de Santa Teresa) e em Catalão (GO) funcionam escolas comunitárias que utilizam o PEVH. Em Campo Grande (MS), um grupo de empresários está criando um núcleo educacional com os principios do programa. Em Paracatu (MG), a prefeitura local prepara a introdução do programa nas escolas da rede pública. O Campus Universitário Bezerra de Menezes, em Curitiba, realiza seu trabalho pedagógico com base na proposta do PEVH. E a Universidade de Uberaba tem um mestrado em ciências e valores humanos. (...)" (pp.26-7)

As considerações de MARTINELLI (1999) sobre Valores Humanos e o programa que já existe especificamente no estudo deste tema, demonstra o interesse de educadores e pesquisadores em buscar a valorização desta questão na formação integral das crianças. Em seu livro "Conversando sobre educação em Valores Humanos a escritora e pesquisadora apresenta algumas técnicas como harmonização; análise de provérbios; canto conjunto; narrativa de contos, mitos, fábulas. lendas e parábolas, expostas detalhadamente, a fim de auxiliar o educađor na utilização de estratégias capazes de canalizar energias, diminuir situações de violência, favorecer o diálogo e a reflexão no convivio social, enfim, apresenta alguns elementos que podem nortear o educando a encontrar o seu eixo de equilibrio

Não se trata, obviamente, de receita ou fórmula mágica e infalivel, mas o $P E V H$, já representa o início de uma possivel praticidade de algo considerado importantíssimo para todo ser humano que é a solidificação da importância dos Valores Humanos em nossa vidas.

Neste ponto, a escola aparece, novamente, com um papel básico fazendo simultaneamente o seu trabalho de construção junto à criança $e$, ainda, aos educadores e à família, pois o principio da universalidade dos valores precisa seguir os padrões da coletividade, da cooperação e da parceria.

\subsection{Programa de Educação em Valores Humanos: reflexões a partir de algumas histórias infantis}

\footnotetext{
- Desejo e vontade são constantemente confundidos. O desejo surge, se intensifica e depois se esvanece simplesmente porque conseguimos realizá-lo. O desejo realizado se esvazia por si mesmo e logo nasce outro, mais exigente. Os fios dos desejos podem nos tornar marionetes. Só vontade tem o poder de acalmar os desejos e legitimá-los, avaliando sua importáncia. A vontade une motivação e significado; é alimentada pelo reconhecimento dos valores espirituais, éticos e estéticos., que, por sua vez, indicam a que se procura na vida $\theta$ o sentido que se dá ao fato de estar vivo. A vontade é movida, pois, pela nossa natureza divina."
}

Marilu Martinelli 
Um Programa de Educação em Valores Humanos constitui-se como um elemento valiosíssimo na elaboração do currículo e deve ser instaurado de maneira interdisciplinar assim como acontece com os temas transversais nos Parâmetros Curriculares Nacionais, onde a Ética, a Pluralidade Cultural, a Orientação Sexual, o Meio Ambiente e a Saúde são temas a serem estudados e discutidos o tempo inteiro, sem distinção de disciplina ou momento escolhido especificamente para uma reflexão sobre os mesmos, pois isto fragmentaria a abrangência de seu significado maior que é ininterrupto e constante na vida dos educadores e educandos, em seu dia-a, dentro e fora do contexto escolar

O programa deve apresentar-se como um trabalho a ser desenvolvido em todas as disciplinas por todas os professores/educadores e educandos. Quando dizemos educadores, estamos referindo-nos a todos os que lidam direta ou indiretamente com os educandos no ambiente escolar e isto envolve funcionários, auxiliares administrativos, merendeiras, equipes técnicas, enfim, todos aqueles que precisam ter ciência, sentir e acreditar, realmente, que a sua postura profissional e humana, ou seja, seu procedimento de vida de modo geral, acarretará sempre conseqüências na vida de outras pessoas.

Parece meio utópico trabalhar um Programa de Educação de Valores Humanos com os educandos também fora da sala de aula; no entanto, a criança é uma só, não se divide em momentos de 'dentro' e 'fora' da classe. O que vivencia com seus companheiros e com seu professor/educador, em um espaço mais restrito de uma sala precisa ser vivenciado e comprovado também em outros momentos fora deste espaço, já que os valores não possuem fronteiras e nem barreiras para sua experimentação.

Surge aí, a importância da união de todos os participantes do contexto escolar neste partilhar de vivências que auxiliem o educando na constatação de valores vivenciados nas mais diversas situações, refletidos com seus pares e percebidos, também, naqueles que habitam o espaço da escola.

Quando o professor/educador discute com seus alunos sobre a importância do respeito ao próximo, do diálogo, do ouvir o outro, eles precisam vivenciar isto não só com seus colegas, mas ao sair e perceber o modo como o funcionário da limpeza se dirige a eles quando passam pelos corredores da escola, como o inspetor de alunos os recebem quando chegam à escola e quando a deixam ao final do periodo, como a merendeira serve suas refeições diárias, enfim, os alunos precisam sentir a vivència destes fatores éticos básicos para que realmente constatem e sintam 'na pele' a importância dos princípios dos valores como indispensáveis à vida de todos, no sentido de lhes garantir direitos de uma boa vida, mas também de deveres que assegurem esta boa vida a eles próprios e aos outros.

Neste sentido, a equipe escolar deve buscar alternativas de atuação que desencadeiem esta vivência de valores por todos na escola, aproveitando os momentos de reunião com os diversos segmentos para leitura de textos ou discussão de situações que permitam, posteriormente, uma reflexão e encaminhamento de procedimentos, de atividades que criem vínculos significativos na vivência de valores humanos destes participantes, de momentos lúdicos que aproximem funcionários, educandos, professores, equipe técnica, enfim, da criação 
de circunstâncias que auxiliem cada educador - independentemente de sua função específica, pois o primeiro contato que tiver no trato com a criança significará sua participação na história da mesma, portanto deve sentir-se responsável, também por algo que ficará na formação deste ser - a vivenciar a importância dos valores, das atitudes baseadas na Ética e na possibilidade que isto traz para a melhoria de.sua própria vida e da vida dos que com eles convivem, e ainda para a história de vida da humanidade, pois no encadeamento de atitudes justas e benéficas de maneira universalizante, estaremos melhorando o mundo não só em nossa atuação local, mas, conseqüentemente, de modo global e universal

Cabe, também, à escola o papel de buscar envolver a familia, ou o que for possivel de se trabalhar com os seus representantes disponiveis - já que a estrutura que temos atualmente de família não é a mesma de algum tempo atrás, quando era mais comum contar-se com a presença do pai, da mãe, dos avós, tios, primos, enfim, de pelo menos um representante da grande árvore genealógica da história de vida familiar de cada criança -, aproximando-os das propostas do programa, incentivando-os a dividir a importante tarefa de auxiliar os educandos na vivência dos valores tão importantes para suas vidas.

Mas, paralelamente a este auxilio destinado às crianças, os representantes da própria familia precisam ser auxiliados na vivência e reflexão sobre o significado de suas próprias vidas, da importância que representam as suas atitudes perante os outros e, principalmente, estarem cientes e sensibilizados, acreditando no valor do papel de educadores que desempenham junto à criança, mesmo sem possuirem oficialmente o título de professores ou mestres, pois, também, educam a cada dia as crianças, mesmo fora do ambiente escolar.

O trabalho em parceria da escola com a familia é fundamental, pois um Programa de Educação em Valores Humanos precisa permear todas as faces da vida dos educandos, uma vez que a educação acontece no seu cotidiano dentro e fora do contexto escolar e quanto mais parceiros a escola conseguir na implementação desta proposta curricular, maior será a sensibilização e a sedução da criança pelos principios norteadores da vivência dos valores.

A literatura como carro-chefe de um Programa de Educação em Valores Humanos pode auxiliar, sobremaneira, na vivência e formação de hábitos, desencadeamento de atitudes e procedimentos que favoreçam o educando em sua vida cotidiana, por meio das histórias diversas que tiver contato.

Como elemento desencadeador de discussões e reflexões que levem à vivência de valores, por intermédio do mundo precioso das histórias, a literatura pode constituir-se como o ponto básico deste programa, sendo que o educador precisa ser muito cuidadoso para que ela não se torne pretexto ou suporte secundário como já discutimos anteriormente.

É preciso que através da literatura haja um fluir crescente do pensar sobre a vida e seu significado $e$, além disto, do que se pode fazer para melhorar a nossa própria vida e a dos outros a partir de nosso próprio viver, de nossa relação com os demais e das atitudes que tomamos no dia-a-dia.

Antes de mais nada, é preciso que se reflita sobre os valores de forma abrangente, sem quaisquer preconceitos ou tendências que possam desencadear 
uma concepção pejorativa relacionada à doutrinação moral de maneira radical e irrestrita

As histórias são um rico filão para a discussão sobre todos os tipos de atitudes apresentados pelas mais diversas personagens nas mais diversas situações. e podem servir como ponte de reflexão dos educandos, percebendo que o ser humano possui qualidades e defeitos e no seu todo, ou melhor dizendo, na sua essência busca a perfeição ou o equilibrio, mas isto precisa ser construido no dia-a-dia, exige esforço e dedicação - o que só pode ser conseguido se o educando estiver motivado para -, caso contrário, se não perceber o que isto realmente pode trazer de bom para sua vida, não se esforçará para obtê-lo.

Como motivar, então, o educando, a perceber a importância dos valores humanos na vida e buscar vivenciá-los nas mais diversas situações? Este parece ser o grande desafio desta proposta curricular.

Partindo-se da importância da literatura como foi apresentada anteriormente, é preciso ter clara a idéia de que as histórias não devem ser fechadas em si mesmas após sua apresentação, ou seja, a moral da história, não pode ser apresentada à criança de forma acabada, sem margem a uma posterior discussão. É preciso discutir com as crianças, refletir sobre seus pontos de vista a partir do que ouviram ou do que leram e, juntos, educador e educandos traçarem possiveis alternativas para as situações vivenciadas pelas personagens.

$\dot{E}$ imprescindivel que sejam propostas possibilidades de procedimentos diversos e que sejam discutidas as alternativas que seriam benéficas a todos, $e$, também. o contrário - o que não beneficiaria e poderia prejudicar as pessoas -, e, finalmente, o que o grupo consideraria melhor. Deve-se prever, ainda, a possibilidade, de discórdia por alguns, buscando discutir e justificar o 'porquê' de opiniões diferenciadas, enfim respeitar o direito de cada um argumentar $e$, ao mesmo tempo, tentar traçar caminhos de reflexão para que cada um possa, após ouvir todos, argumentar e refletir sobre amplas possibilidades de vivência, decidir o que considera melhor para sua própria vida e a de seu próximo, sem quaisquer cobranças por sentimentos de culpa ou receio de punição.

O professor/educador precisa compreender que os valores - os principios básicos de convivência estruturados na Ética -, não podem e nem devem ser impostos, pois isto iria contra o sentido maior da opção pelos mesmos por meio da autonomia. O que precisa ser universalizado é aquilo que se baseia na justiça. Se, por exemplo, o valor 'amizade' é vivenciado e acreditado na escola porque isto confere a todos o direito ao convivio coletivo de maneira equilibrada e harmoniosa, então ele realmente deve ser buscado por todos, pois neste sentido é justo à boa vida de todos; caso contrário, se algum valor é buscado apenas para atender às expectativas de um pequeno grupo, seja da direção da escola ou de uma vontade reducionista e subjetiva do professor/educador, então este valor perderá sua essência básica e universalizante e não será, portanto, ponto de consenso gerador de motivação e assimilação para os alunos.

Em relação às colocações anteriores sobre a vivência da Ética, dos valores de maneira autônoma e reflexiva, LA TAILLE (2000), em uma reportagem concedida à revista Pátio intitulada 'Formação ética: direitos, deveres e virtudes', dá-nos 
importantes contribuições à reflexão em relação à obrigatoriedade ou não da implementação destes valores ao educando:

"(...) Se formos ler o famoso texto de Aristóteles intitulado Ética a Nacômaco, verificaremos que o filósofo grego coloca na sua ética virtudes como a temperança, coragem, prudência, magnanimidade etc. A razão da inclusão de tais virtudes é clara dentro de um filosofia aristotélica: uma vez que a ética é definida como uma 'arte de viver', como uma busca da felicidade, faz sentido incluírem-se nela traços de caráter e condutas que são necessários ao alcance desta felicidade. Porém se formos ler a obra de Kant (século XVIII), teremos uma visão totalmente diferente do que seja ética: longe de ser concebida como busca de felicidade, ela é construída a partir da noção de dever. é ético (ou moral) aquilo que se faz com base no respeito dos direitos alheios, direitos estes que são derivados de um imperativo categórico preciso: as pessoas nunca devem ser tratadas como meios, mas sim como fins em si (não podem, portanto, serem 'usadas' para benefício alheio). Deste ponto de vista, que, grosso modo, corresponde à ética moderna, apenas uma das virtudes citadas por Aristóteles pode ser, sem maiores objeções, objeto da ética: a justiça (...) Todos devem procurar agir de forma justa, e toda injustiça deve ser implacavelmente condenada e abolida. Em compensação, não é um dever ético ser corajoso, ter humildade, ser prudente etc. Ou melhor dizendo, tais virtudes somente corresponderão a deveres se exercidas em nome da justiça: ser corajoso para opor-se a arbitrariedade, ser humilde para reconhecer que não se foi justo, ser prudente para garantir que a justiça se faça etc (...)" (pp.8-9)

Podemos perceber até este ponto de nossa discussão que a literatura pode desencadear múltiplas possibilidades de reflexão sobre os valores e o experienciar de situações propicias a abordagens relativas à ética, com base no dever ou n̊̆o, na obrigatoriedade ou não, de se implementar as diversas virtudes existentes que permeiam a conduta humana.

O grande cuidado, no entanto, que precisamos ter, neste sentido, é o de deixar bem claro, a partir da histórias apresentadas, que qualquer reflexão feita irá ser considerada e colocada com respeito, em discussão, pois vem do aluno e geve ser atendida, discutida e trabalhada.

O papel do professor/educador é vital neste trabalho de ouvir o educando e, ainda, na escolha das histórias com os mesmos, buscando sempre tentar universalizar os benefícios éticos ou prejuizos anti-éticos, relacionando-os aos procedimentos apresentados nas histórias, enfocando nelas aspectos positivos e também negativos, partindo da discussão de determinadas colocaçōes radicais ou preconceituosas, que acabam neutralizando a capacidade criadora e reflexiva dos educandos, caso não seja realizada uma argumentação aprofundada e polêmica sobre os assuntos pautados.

Tomando como exemplo a apresentação de algumas histórias na abordagem do Programa de Educação em Valores Humanos, uma boa estratégia para a realização do trabalho pode ser a de tentar desmistificar alguns paradigmas sócio-históricos arraigados nas mentes de educadores e educandos, e da sociedade de modo geral, ou seja de valores que se perpetuam através dos tempos sem que haja uma discussão séria capaz de revê-los em sua fundamentação, se é que podemos assim considerá-los, tendo em vista discussão que já desenvolvemos sobre a transitoriedade de alguns padrōes de valores que, independentemente, da abrangência universal que precisam obedecer diante dos critérios de justiça que 
são de direito a todos, podem ser repensados sem que isto traga danos ou prejuizos às pessoas.

Quando abordamos algumas histórias com os alunos, é preciso que tenhamos o cuidado para não passarmos a idéia de que exigimos deles a eterna perfeição e uma radical cobrança daquilo que é socialmente recomendável. É preciso discutir-se o bem e o mal, que nos reconheçamos em nossas falhas ou dificuldades e também em nossos acertos, sem que isto rotule ou estigmatize um ou qutro

O importante é que se discuta, que se polemize e que se semeie pontos de reflexão que conduzirão à vivência de valores por iniciativa dos próprios educandos e não como resultado da repetição de determinadas posturas de maneira imitatiya, só porque decorrentes de estereótipos ou valores impostos socialmente. Se estes cuidados forem preteridos, por nós, professores/educadores, estaremos correndo o risco de observar nossos alunos desempenhando papéis apenas para atender às nossas expectativas de adultos, talvez tentando nos agradar ou por receio de alguma sanção ou constrangimento, mas não pelo processo de formação de valores pelos quais optaram como importantes para sua própria vida por assim acreditarem como realmente importantes e significativos.

PUIG (1998a) ressalta a importância de o professor/educador favorecer processo de reflexão do educando através de algumas estratégias pedagógicas de vivência de valores. Uma destas estratégias são as perguntas clarificadoras, que se encarregam de questionar as opiniões de alunos e alunas, os motivos de suas escolhas, o que apreciam nos fatos ou desejariam fazer e, enfim, sobre quais valores conduzem suas vidas. Para o referido autor:

"(..) São questões que querem ser um estimulo para esclarecer seus pensamentos e suas condutas e, definitivamente, para clarificar seus valores. De certa forma, o educador atua de modo socrático: semeando a dúvida nos alunos e ajudando-os a concluir um processo de auto-reflexão que thes devolva certas seguranças valorativas." (p.41)

Muitas histórias podem auxiliar o professor/educador neste trabalho de reflexão sobre os Valores Humanos. Faremos a seguir o comentário sobre algumas, dentre as inúmeras possibilidades de opções existentes, apenas para ilustrar a importância da discussão sobre os valores apresentados em uma pequena mostra de histórias, de maneira explicita, e, na maioria da vezes, de forma subliminar, mas profundamente, significativa para a criança/ educando.

Quando QUINTANA (1997) inicia com um belissimo pensamento a abertura de seu livro 'Lili inventa o mundo', percebemos a importância do mundo encantado das histórias, do sonho e da imaginação na vida da criança e do significado que elas fazem para o universo infantil, traçando pontes de motivação e interesse e, a partir dai, podemos pensar na criação de possibilidades de vivência e reflęxão sobre os Valores Humanos em suas próprias vidas:

\section{"As pessoas sem imaginação}

podem ter tido as mais

imprevistas aventuras, podem ter 
visitado as terras mais estranhas. Nada

Ihes sobrou. Uma vida não basta

para ser vivida: também

precisa ser sonhada."

Assim, as histórias levam ao sonho, mas também trazem a reflexão sobre a própria realidade. Trata-se de uma ponte de significações que o professor/educador pode e deve ajudar a construir e mediar

$\mathrm{Na}$ primeira história que apresentaremos, a título de exemplificação reflexiva, ROCHA (1984), já, no início, dá-nos uma idéia de algo novo e irreverente para ser pensado

\author{
"Uma história que parece \\ história de fada mas não é. \\ Também parece história \\ para criança pequena mas \\ não é."
}

(p.1)

Procurando Firme - Ruth Rocha (1984)

$\mathrm{Na}$ história, alguns valores são questionados sobre o que é realmente ser uma princesa. Em geral, algumas colocações podem nortear a narrativa que se passa na história em relação à obrigatoriedade e imposição de valores, que, no caso, não constituem o bem coletivo, já que trazem o descontentamento da princesa em detrimento de padrões de valores pre-estabelecidos no reino, devendo, portanto, ser questionados e reavaliados. Poderíamos, assim, em uma leitura subliminar, associar o que se espera da princesa ao que se espera da menina, da moça, da mulher na sociedade:

- Haverá um padrão único de comportamento para a princesa?

- E se ela quiser portar-se de maneira diferente será que não encontrará o seu principe?

- E por que será que toda princesa tem mesmo que encontrar o seu príncipe, ter cabelos longos sempre, ter aulas de canto, pintura e bordado?

- E se todas estas coisas mesmo sendo tipicamente de princesa como dizem e exigem as pessoas do reino não trazem felicidade para a princesa?

- E se ela quiser rir alto, cortar os cabelos, sair do castelo e encontrar o seu próprio principe sem esperar que ele venha a ela? 
É importante ouvir o que as crianças têm a dizer sobre a história e com elas construirmos as reflexões, sempre com o cuidado de não direcionar a discussão segundo nossos próprios valores. As associações para a vida da própria criança surgem naturalmente sem que forcemos para que isto aconteça. As crianças sempre nos surpreendem com as relações que são capazes de fazer e das possibilidades de situações que são capazes de criar

Esta história é muito importante para que possamos rever com as crianças os valores impostos de maneira conveniente à sociedade consumista em que vivemos, onde a reflexão é imprescindivel para que somente os verdadeiros valores - aqueles que trazem uma boa vida a todos - , sejam vivenciados porque foram discutidos e escolhidos pelos educandos por consciente iniciativa e não por imposição de uma massa coletiva, que age em conformidade ao senso comum, sem saber para onde realmente está sendo levada.

\section{Chapeuzinho Amarelo - Chico Buarque (1994)}

A história apresenta uma menina chamada Chapeuzinho Amarelo que tinha medo de tudo na vida: trovão, minhoca, sombra, pesadelo ... e o medo mais medonho que tinha era o medo do LOBO... Mas de tanto pensar e sonhar com o LOBO no dia que o encontrou de verdade, descobriu que não tinha mais medo dele... E o lobo ficou chateado porque perdeu seu crédito de medo com Chapeuzinho Amarelo. Ela inventou uma brincadeira que transformou os seus medos em outras coisas: o LOBO virou BOLO... o raio virou orrái... a barata virou tabará... a bruxa virou xabru...o diabo virou bodiá... E a menina nunca mais teve medo de nada

Nesta história, pode-se pensar em algumas hipóteses de reflexão sobre valores pré-estabelecidos às crianças que podem e devem ser questionados:

- Será que toda a criança tem realmente medo do LOBO ou algumas colocações são feitas neste sentido para chantageá-la em algumas situações usando-o como subterfúgio: 'faça isto, senão o LOBO yem pegar você'..

- A criança apresenta alguns medos próprios e característicos de sua descoberta gradativa do mundo, mas até que ponto isto é tratado de forma natural ajudando-a a superar seus medos e inseguranças? Até onde $O$ adulto reforça consciente ou inconscientemente estes medos como comuns ao universo infantil tentando perpetuá-los em valores préconcebidos? Isto pode ser observado, também, em algumas canções de ninar, contraditórias pela própria denominação que lhes é conferida, pais, ao invés de acalmar, ninando, trazem mensagem de amedrontamento ou coação: "boi, boi, boi...boi da cara preta, pega esta menina que tem medo de careta..."

- As crianças precisam realmente ter medo das coisas - muitas vezes como suporte do adulto para controlá-las mais facilmente, ou até justificando que isto será melhor para a sua própria proteção? - ou é preciso auxiliá-las a encarar suas dificuldades, fazendo delas uma brincadeira como criativamente pensou Chapeuzinho Amarelo? 
As hipóteses levantadas servem-nos para uma reflexão associativa a partir de histórias que são consideradas como clássicos da literatura. Chapeuzinho Amarelo remete-nos, em um primeiro momento, à conhecida história de Chapeuzinho Vermelho. A história tradicional (Chapeuzinho Vermelho) serve para ilustrar uma polêmica discussão porque faz parte de um exemplo, entre tantos outros, de contos populares perpetuados através dos tempos, no vasto universo da literatura e caracterizados pelo que Marc Soriano (nascido em 1918) chamou de 'pedagogia do medo'. Nestes contos populares elaborados a partir da pedagogia do medo são apresentados riscos e perigos dos quais as crianças precisam afastar-se para sua própria proteção. Em muitos deles, também é apresentada a defesa de valores como a virtude, o trabalho e a esperteza.

Na primeira versão de Chapeuzinho Vermelho (1697) apresentada no livro Contos da Mãe Gansa, de Charles Perrault (1628-1703), a história não termina com um final feliz: Chapeuzinho é punida por sua desobediência à mãe e acaba sendo devorada pelo lobo mau, sem que nenhum caçador apareça para salvá-la. O final feliz aparece apenas na segunda versão da história, no século XIX, por obra dos irmãos Grimm, apresentando um desfecho diferente do anterior: a barriga do lobo é reenchida com pedras, depois de serem retiradas de lá Chapeuzinho e sua avó. A versão brasileira, apresentada por autoria de João de Barro, pseudônimo do carioca Carlos Alberto Ferreira Braga (nascido em 1907), anuncia um final feliz parecido com o da versão anterior: o lobo é morto pelos caçadores e estes ajudam Chapeuzinho, que estava muito triste pelo fato de sua avó ter sido devorada pelo perverso animal. Eles cortam a barriga do lobo e retiram de lá a avó de Chapeuzinho, ainda viva, para felicidade da menina.

A Chapeuzinho Vermelho de outrora propicia à criança a oportunidade de vivenciar seus medos e inseguranças em um processo de catarse, colocando-se no lugar da personagem principal, elaborando sentimentos e emoções importantes para o seu desenvolvimento $e$, ainda, percebendo que deve estar atenta aos perigos da vida. No entanto, que outras possibilidades de solução poderiam ser dadas à protagonista se não fosse a ajuda dos caçadores que ocorre na segunda e terceira versōes? Ou ainda, como na primeira versão, quando não ocorre um final feliz, pensará a criança que sempre será punida radicalmente por não fazer o que o adulto Ihe aconselhou? Onde fica então a construção da legitimidade das regras pela reflexão e pela autonomia e não pela severa coação?

Estas reflexões precisam ser desencadeadas pelo professor/educador na discussão sobre as histórias com as crianças. Embora com títulos e algumas semelhanças na narrativa, sob o ponto de vista da mensagem subliminar que nos induz à reflexão sobre alguns valores na formação da criança, podemos considenar Chapeuzinho Amarelo como uma história 'às avessas' de Chapeuzinho Vermelho no sentido da não submissão ao que já está pronto e tem de ser aceito, de que é comum e normal ter de se submeter ao medo e a temê-lo -, onde a criança deve ser questionada e indagada sobre sua própria iniciativa para resolver os seus medos e conflitos. Ela precisa perceber que o adulto pode auxiliá-la quando precisar e, ao mesmo tempo, que é capaz de inventar, criar caminhos alternativos para lidar com suas inseguranças e curar os seus próprios fantasmas interiores. $E$ isto só pode ser construído se o professor/educador oferecer oportunidades para que a criança vivencie valores de forma significativa a partir das discussões e reflexōes que forem propostas. 


\section{O Lobo e o Carneiro no Sonho da Menina - Marina Colasanti (1998)}

Esta história traz algumas reflexões sobre idéias pré-concebidas a respeito de medos arraigados que se tem em relação a algumas situações vivenciadas pelas personagens de diferentes histørias.

Neste caso, o lobo - que, de tanto aparecer em outras histórias acabou tornando-se um temido vilão porque assim o constituiram e the conferiram tal poder, e que por uma questionável lógica, enraizada de tantos e tantos valores de subserviência a ele dirigidos, mereceria tal temor - aparece de maneira diferente nesta narrativa, sendo percebido segundo outros valores inusitados pelas personagens.

A menina - que sonha todas as noites com um lobo e um carneiro que parecia ser indefeso e inofensivo, mas que, de repente, mostra-se, também, feroz e capaz de se defender do lobo - acaba descobrindo que não teme mais sonhar com o lobo e nem com o carneiro, que não era tão frágil e indefeso como parecia. Ela decide que pode controlar o seu próprio sonho, colocando os lobos e os carneiros em seu devidos lugares, pois já não tinha medo de nada.

Algumas considerações merecem ser feitas em relação a esta história.

- Como as crianças caracterizam o lobo e suas aparições? Este valor de um medo exagerado nele perpetuado não merece ser revisto e questionadp?

- E quanto ao carneiro? Será que deve ser sempre tão dócil como as pessoas dizem que é? Não pode mostrar também sua raiva para se defender com justiça quando ameaçado? Isto não faz parte também da cidadania, da ética e do direito de cada um? Por que o sentido obrigatónio de submissão que the conferem precisa ser seguido? Será que os carneiros - como dita a expressão popular de eterna concordância a tudo e a todos - devem dizer 'amém' o tempo inteiro, apenas ratificando opiniōes e se submetendo aos outros, sem direito ao seu próprio momento, à sua própria vontade, ao que lhe é de direito por justiça?

- Todas as meninas precisam mostrar-se indefesas e amedrontadas diante de lobos ferozes e até de carneiros que se mostram, às vezes meio hostis, que aparecem em seus sonhos? Será que elas não conseguem dominar os seus próprios sonhos, medos e inseguranças?

$\dot{E}$ importante que as crianças percebam que é as pessoas costumam exigir determinados valores impostos socialmente como regra padrão de comportamentQ e atitudes desejáveis porque conferidas ao senso comum; no entanto, ao mesmo tempo precisam perceber que possuem o poder de decisão por aquilo que consideram justo e humano para todos e que sua atuação é imprescindivel na construção de um mundo melhor.

As histórias apresentadas aqui representam apenas uma pequena mostra da importancia do professor/educador no trabalho de reflexão com as crianças a partir da riqueza de material oferecido pela literatura para a análise de padrões de valores perpetuados através da secularidade de vida das histórias que constituiram, constituem e constituirão a humanidade.

Trata-se de um trabalho delicado, frágil e que exige muita perspicácia do professor/educador ao lidar com os diferentes temas apresentados nas histórias e 
com as inesperadas questões que podem surgir quando a reflexão se amplia e os educandos criam pontes de múltiplos significados a partir de suas próprias vivências de valores.

Parece ser este o grande desafio de nossa atuação docente: tentar conduzir à reflexão sem direcionar, orientar sem impor, desafiar sem subestimar, enfim, buscar vivenciar com os alunos tudo aquilo que poderá auxiliá-los em sua própria caminhada e na caminhada da humanidade pela vida afora de maneira equilibrada, plena e feliz.

\title{
5.6. Projeto de Literatura Infantil e Valores Humanos: vivenciando histórias com as crianças antes e depois da alfabetização
}

\author{
" A mais importante busca humana \\ é esforçar-se pela moralidade em nossa ação. \\ Nosso equilibrio interno, inclusive da existência, depende disso. \\ Somente a moralidade em nossas ações \\ pode dar beleza e dignidade à vida. \\ Fazer disso uma força viva e trazê-la para a consciència \\ é talvez a tarefa principal da educação. '
} Albert Einstein

- A arte pedagógica, realmente prática, nảo pode nascer de uma mentalidade materialista. Se o homem não se sentir unido a algo superior, por meio de laços seguros, sua vontade e seu caráter permanecerão dúbios, desintegrados e até doentios. Rudolf Steiner

\section{Primeiro momento da pesquisa: a implementação do projeto} - $2^{\circ}$ semestre de 1998

Pensando em um programa calcado na vivência dos Valores Humanos na escola, partindo do eixo central da literatura, surgiu a idéia de trabalhar com estas questões com as crianças, por meio de um projeto intitulado 'Literatura Infantil; uma viagem de transformação através dos Valores Humanos.' 
Este projeto foi implementado como resultado do estágio supervisionado, realizado sob orientação da Profa Dra Lenira Haddad, no $2^{\circ}$ semestre de 1998 , ao término do Curso de Especialização em Educação Infantil, iniciado em março de 1997, na Faculdade de Educação da Universidade de São Paulo; servindo, simultaneamente, também, como pesquisa de campo do presente trabalho, visando aprofundar, ilustrar e mostrar a importância da Literatura na formação de camimhos para uma Educação em Valores Humanos.

\section{Justificativa}

Como justificativa à idéia do projeto, pensou-se na defasagem no atendimento à questão sócio-afetiva das crianças, tanto na familia quanto na escola, - que resulta em desequilibrios nas relações intra e interpessoais ${ }^{5}$, surgindo a emergente necessidade de criar caminhos alternativos, em busca de uma verdadeira qualidade de vida infantil.

Este projeto surgiu da idéia de se elaborar um trabalho direcionado aos "Valores Humanos", tendo como ponto de partida a exploração de diversas histórias inerentes à Literatura Infantil, por constituir, esta, um universo de rico significado para a criança pequena, e por perpassar, de maneira prazerosa, todas as fontes de interesse e motivação baseadas no faz-de-conta, no lúdico e na fantasia, tipicamente peculiares da faixa etária pré-escolar

\section{No Programa de Educação em Valores Humanos, MARTINELLI. (1996) esclarece}

"Nietzsche deu status filosófico aos valores, mas foi Max Weber quem atuou na pesquisa dos valores, na descrição dos fenômenos ou das essências puras que ocorrem na consciência. Por meio dessa exploração, Scheler concluiu que os valores pertencem a uma esfera que não se confunde com a do ser, pois possuem uma peculiaridade irredutivel. São percebidos não por uma introspeç̧ão simples, mas por uma instituição emocional (...) Os valores humanos são fundamentos morais e espirituais da consciência humana. Todos os seres podem e devem tomar conhecimento dos valores a eles inerentes(...) A vivência dos valores alicerça o caráter, e reflete-se na conduta como uma conquista espiritual da personalidade." (pp.14-15)

A BRAMA KUMARIS é uma conhecida organização internacional nãogovernamental, afiliada ao departamento de Informações Públicas da ONU, com status consultivo no Conselho Econômico e Social das Nações Unidas e no UNICEF, fundada na Índia, em 1937, que possui escolas em 65 paises e vem aplicando programas de educação sobre os valores humanos, éticos e espirituais, durante sessenta anos, desenvolvendo projetos para a revalorização do ser

\footnotetext{
${ }^{5}$ As relações intra e interpessoais referem-se à terminologia usada por GARDNER (1995) em .\$eu livro Inteligencias Múltiplas. Referem-se a uma subdivisão da inteligência emocional. Segundo Gardner, a inteligência intrapessoal relaciona-se "ao conhecimento dos aspectos intemos de uma pessoa: o acesso ao conhecimento da própria vida, à gama das próprias emoçठes, à capacidade.de discriminar essas emoçós e eventualmente rotulá-las e utilizá-las como uma maneira de entender e orientar o próprio comportamento(...) A inteligéncia interpessoal está baseada numa capacidade nuclear de perceber distinçסes entre os outros; em especial contrastes em seus estados de ánimo, temperamentos, motivações e intençס̃es. (pp.27-28).
} 
humano. A organização BRAMA KUMARIS (1997), em seu projeto intitulado Vivendo valores na escola - Manual do professor, enfatiza a importancia da escola na promoção de valores: fonte de energia que mantém a autoconfiança e a objetividade. Hoje, na maioria dos paises, os povos são influenciados pela ideologia materialista que cria uma cultura de acúmulo, posse, egoismo e ganância. Conseqüência: os valores autênticos perdem o brilho da verdade e a força para sustentar e preservar uma cultura digna do ser.

"Os valores motivam o comportamento e a atividade humana. São a fonte de energia que mantém a autoconfiança e a objetividade. Hoje, na maioria dos paises, os povos são influenciados pela ideologia materialista que cria uma cultura de acúmulo, posse, egoismo e ganância. Conseqüência: os valores autênticos perdem o brilho da verdade e a força para sustentar e preservar uma cultura digna do ser humano. Essa distorção de principios é uma das causas da crise em que vivemos no mundo moderno, marcado pela inquietação, insegurança e, obviamente, ausência de paz.

A violência, os comportamentos negativos, estimulados pelos meios de comunicação, a desagregação da família, as desigualdades sociais são alguns dos resultados visiveis de uma época contaminada pela inversão de valores.

Este quadro indica a necessidade de reformarmos nosso comportamento e, para que isso aconteça, temos que resgatar os momentos de verdade e harmonia no planeta Terra... O colégio é, hoje, o local onde se aprende cada vez mais sobre o universo físico, e muito pouco sobre o mundo interior e subjetivo. Com a crescente informatização, a tendência é aumentar o conteúdo informativo, em detrimento do formativo, que é um fator preocupante, pois se constata que essa é a principal função da escola...Com a inclusão do estudo de valores, de maneira formal e informal, nos curriculos, haverá tempo para este trabalho de grande alcance. É o passo inicial de autoconhecimento, que conduzirá à transformação para a melhoria dos relacionamentos em todos os niveis, tornando as aulas mais atrativas e a escola um rico laboratório de vivências positivas, onde as crianças e jovens se desenvolverão à luz dos pensamentos e bons sentimentos." (p. 6)

Considerando-se o resgate dos valores humanos e com base, também, ęm outras propostas direcionadas a esta meta, esse projeto visou ressaltar o papel da escola ao voltar-se para o trabalho com histórias infantis, como um tesouro de incalculável valor, semeando idéias, de profundo significado, nas mentes infantis.

As duas fontes supracitadas (MARTINELLI \& BRAMA KUMARIS) sugerem alguns valores que merecem ser desenvolvidos e vivenciados pelas crianças: verdade, ação correta, paz, amor e não violência. MARTINELLI (1996, pp. 20-25) cita valores centrais e valores relativos (subvalores), conforme o quadro a seguir: 


\begin{tabular}{|c|c|}
\hline Valores centrais & Valores relativos (subvalores) \\
\hline VERDADE & $\begin{array}{l}\text { otimismo, discernimento, interesse pelo conhecimentp, } \\
\text { auto-análise, espírito de pesquisa, perspicácia, atenção, } \\
\text { reflexão, sinceridade, otimismo, honestidade, exatidão, } \\
\text { coerência, imparcialidade, sentido de realidade, justiça } \\
\text { lealdade, liderança, humildade. }\end{array}$ \\
\hline AÇÃO CORRETA & $\begin{array}{l}\text { dever, ética, honradez, vida sadia, iniciativa, } \\
\text { perseverança, responsabilidade, respeito, esforço, } \\
\text { simplicidade, amabilidade, bondade, disciplina, limpeza, } \\
\text { ordem, coragem, integridade, dignidade, serviço à } \\
\text { próximo, prudência. }\end{array}$ \\
\hline PAZ & $\begin{array}{l}\text { silêncio interior, calma, contentamento, tranqüilidade, } \\
\text { paciência, autocontrole, auto-estima, autoconfiança, } \\
\text { auto-aceitação, tolerância, } \\
\begin{array}{ll}\text { desprendimento (desapego). } & \text { concentração, }\end{array}\end{array}$ \\
\hline AMOR & $\begin{array}{l}\text { dedicação, amizade, generosidade, devoção, gratidão, } \\
\text { caridade, perdão, compaixão, compreensão, simpatia, } \\
\text { igualdade, alegria, espirito de sacrifício e renúncia. }\end{array}$ \\
\hline NÄO VIOLÊNCIA & $\begin{array}{l}\text { fraternidade, cooperação, concórdia, altruísmo, força } \\
\text { interior, respeito à cidadania, patriotismo, } \\
\text { responsabilidade civica, unidade, solidariedade, respeito } \\
\text { à natureza, respeito pelas diferentes raças, culturas } € \\
\text { religiōes, uso adequado: do tempo, da energia do } \\
\text { dinheiro, da energia vital, da energia do alimento, do } \\
\text { conhecimento. }\end{array}$ \\
\hline
\end{tabular}

Alguns valores foram selecionados para este projeto de estágio por considerar-se de necessária vivência no ambiente escolar, tendo em vista as expectativas e as atitudes dos educandos. São eles: ORDEM - CORAGEM GRATIDĀO - INICIATIVA - PERSEVERANÇA - SOLIDARIEDADE - COOPERAÇÃO - ESFORÇO - RESPEITO - PERDÃO. Buscou-se aliar as características essenciais de cada valor às diferentes situações apresentadas nas histórias da literatura infantil.

\section{Metodologia}

Por meio da leitura de histórias, selecionadas prévia e intencionalmente, o projeto apresentou, como meta principal, oferecer vivências prazerosas e atividades significativas, relacionadas aos Valores Humanos, visando aprimorar as relações intra e interpessoais das crianças, em sua vida cotidiana.

A tarefa primeira deste projeto foi a de aproximar a criança do mundo da leitura, a fim de abrir caminhos ao trabalho reflexivo-prático sobre os Valores Humanos, através de uma sistematização periódica, de atividades realizadas, pelo menos, duas vezes por semana, no período da tarde, com sessões de três horas no total, sendo:

- duas horas destinadas ao trabalho diretamente ligado às crianças; 
- o restante do periodo destinado a:

- observação do comportamento das crianças, em diferentes espaços da escola (sala de atividade, refeitório e parque);

- consulta ao acervo de livros da unidade escolar;

- levantamento de material pedagógico aproveitável para a proposta do presente projeto (fantoches, jogos, brinquedos diversos);

- conversas com a professora, com a equipe técnica e com os pais, sobre encaminhamentos do trabalho.

O grande desafio constituiu-se em buscar, sempre, a ludicidade, o faz-deconta e o mundo da fantasia para atrair e motivar o público infantil e envolvê-lo, simultaneamente, no processo de descoberta dos Valores Humanos, por meio das leituras propostas e, posteriormente, enriquecidas com múltiplas oportunidades de expressão, segundo os temas apresentados.

Os livros foram escolhidos em função dos valores que traziam em seu conteúdo, ou seja, na essência de sua mensagem.

Optamos por priorizar temas de algumas coleções infantis e, também, de algumas histórias do Livro das Virtudes para Crianças, aliando-os à apresentação / vivência de alguns valores, conforme explicitação abaixo:

- A esquilinha caprichosa (ORDEM) da Coleção Balangandã;

- Os três lobinhos e o porco mau (PERDÃO) da Coleção Brinque-Book;

- A formiga e a pomba (GRATIDÃO); A formiguinha e a neve (COOPERAÇÃO); O pintinho Quiquiriqui (CORAGEM ); A festa no céu (SOLIDARIEDADE); Os três porquinhos (INICIATIVA); A galinha ruiva (PERSEVERANÇA) da Coleção Clássicos Infantis;

- Por favor (RESPEITO) ; Hércules e o carreiro (ESFORÇO) do Livro das Virtudes para Crianças

A escolha das histórias baseou-se, fundamentalmente, na estratégia do jogo com as palavras e musicalidade da expressão oral, garantindo a ludicidade na leitura, tanto na forma (estrutura e corpo do texto), quanto no conteúdo (mensagem).

A partir da apresentação e discussão das histórias, buscou-se propor situações-problema que levassem a criança a refletir, fazendo uma ponte entre o enredo apresentado e a vida dos educandos. Várias propostas, capazes de explorar as histórias de forma integrada, foram oferecidas, seguindo, sempre, as diversas possibilidades de (re)criação, oriundas das múltiplas linguagens de expressão infantil.

\section{Breve histórico do ambiente do estágio}

O local para a implementação do projeto foi escolhido por decorrência de um trabalho de assessoria psicopedagógica que vinha desempenhando na escola, 
junto a pais, professores e equipe técnica desde 1996, por meio de palestras realizadas sobre diferentes temas solicitados.

Esta vivência com o grupo propiciou o estreitamento de vinculos com os participantes do processo e favoreceu a realização da proposta apresentada, para a implementação do projeto, pelo fato de conhecer a história da escola, sua trajetória educacional e, ainda, pelo privilégio de poder participar e auxiliar, em muitos momentos, neste percorrer evolutivo da caminhada; no entanto, apesar deste contato esporádico, que, em minha opinião, poderia auxiliar-me, em demasia, ainda percebi algumas dificuldades que serão posteriormente mencionadas para a implementação do projeto.

\section{Local: Colégio "Nascimento"}

Rua Costa Rego, 50 - São Vicente / São Paulo.

Em 1987, na Av. Antonio Emerich, 730, em São Vicente, a atual proprietária do Colégio Nascimento, assumiu uma escola que, na época, chamava-se Casinha de Chocolate.

Na ocasião, a escola dividia-se em três niveis: Maternal, Jardim e Préescola. contando com um total de 180 crianças e 15 funcionários, incluindo professores, auxiliares e servemtes.

Com o passar do tempo, a escola foi crescendo e os pais começaram a solicitar a ampliação dos níveis de ensino, estendendo-se para o antigo $1^{\mathrm{a}} \mathrm{grau}$, hoje, Ensino Fundamental, a fim de que seus filhos pudessem dar continuidade aos estudos, na mesma Unidade Escolar em que estavam concluindo a Pré-escola.

Esse foi o principal motivo da mudança de local e de nome da antiga Casinha de Chocolate para o atual Colégio Nascimento.

Segundo sugestões dos próprios pais, a escola foi "batizada" com o nome de Nascimento, pela associação à idéia de nascer, em outro local, com outro nome e abrangendo niveis posteriores de ensino, além da Pré-escola. O slogan do colégio, também definido por sugestões dos pais, ficou assim determinado: Colégio Nascimento - o futuro de seu filho começa aqui. 12/01/96.

A oficialização do nome, bem como do novo prédio escolar, deu-se a

Na ocasião da realização do projeto, o Colégio Nascimento apresentava os seguintes módulos de atendimento:

- Maternal I (3 anos);

- Maternal II (4 anos);

- Jardim (5 anos);

- Pré-escola (6 anos);

- Ensino Fundamental: $1^{\mathrm{a}}$ a $4^{\mathrm{a}}$ séries.

O colégio contava, então, com um total de 210 alunos e 29 funcionários, no geral, incluindo Equipe Técnica (Diretora e Coordenadora Pedagógica), secretária, professores, pessoal da cantina, serventes e porteiro. 
Havia na escola uma preocupação da Direção com a formação docente em serviço. Para tal, eram estabelecidas reuniões semanais com os professores e a coordenadora, realizadas todas as quartas-feiras, das 17 h30 às 18h30. Nesta ocasião, eram discutidos textos, os professores trocavam experiências, expunham suas dificuldades e buscavam encontrar, juntos, soluções para assuntos levados à reunião, sempre sob a orientação da coordenadora. Além disso, eram oferecjdos cursos de capacitação para o aprimoramento e atualização educacional.

Percebia-se, também, uma atenção especial aos pais, sendo oferecidas palestras, com temas de interesse coletivo para a comunidade, que auxiliavam na compreensão das etapas do desenvolvimento infantil.

A linha de trabalho do Colégio Nascimento valorizava, assim, a Educação Infantil, como um nivel de inigualável valor em si mesmo e, ainda, como base indispensável para o favorecimento da estruturação de niveis posteriores de ensino. Embora tenha ampliado suas instalaçōes para atender, também, ao Ensino Fundamental, segundo reivindicação da comunidade, continuava acreditando na essência de sua existência e origem de sua formação inicial, que se deu com a Educação Infantil há, aproximadamente, dez anos atrás, contados na ocasião da implementação do projeto...

\section{Público-alvo}

\section{Classe de pré-escola: 16 crianças de 6 anos}

As estratégias de trabalho e a fundamentação do desenvolvimento das atividades foram, antecipadamente, discutidas e expostas à Direção do colégio onde foi realizado o estágio para a implementação do projeto, bem como à professora do grupo / classe que se constituiu como público-alvo do projeto. Ambas mostraram-se entusiasmadas e receptivas à consecução das metas apresentadas, o que acreditamos ter sido de vital importância, na parceria que estabelecida, para o aprofundamento posterior das reflexões e vivências desenvolvidas no contexto escolar

\section{Cranograma}

As sessões de implementação foram desenvolvidas, inicialmente, prevendose a consecução do projeto em um total de 16 encontros, duas vezes por semana, durante dois meses, aproximadamente (agosto, setembro e meados de outubro de 1998), em um periodo de três horas em cada sessão.

No entanto, após a $16^{a}$ sessão, devido à necessidade de ampliação do projeto, em conseqüência da reflexão sobre a proposta de trabalho, houve uma reestruturação do cronograma inicial, sendo, o mesmo, prolongado e desenvolviğo por um período de quatro meses (agosto a novembro), abrangendo um total de 29 sessōes. 


\section{Relatório das sessões de estágio para a implementação do projeto}

Apresentaremos, aqui, de forma sucinta, os relatos sobre os encontros com as crianças, tentando demonstrar os fatos que mais se destacaram para ilustrar a importância deste trabalho para elas, por meio de seus depoimentos de entusiasmo, desabafo e reflexão na vivência de valores discutidos a partir do eixo central da literatura

Os momentos das sessōes foram divididos em três itens (objetivo - meta a ser alcançada, ou semeada, no dia; descrição - observação imparcial; comentários - reflexão e análise conclusiva), a fim de exemplificar, de modo pontual, o significado do meu encontro com as crianças e a necessidade de se planejar, sistematicamente, o trabalho, mesmo se considerando a flexibilidade do processo.

As anotações sobre as sessōes foram mantidas no tempo verbal em que as elaborei. na época, e assim as mantive para enaltecer a importância de como senti, na ocasião, a vivência desta rica experiência com as crianças, e com a escola como um todo. voltada para me auxiliar na implementação do projeto.

\section{Primeiro dia - 4/8/98 Objetivo}

Motivar as crianças para o inicio do trabalho com as histórias infantis e os Valores Humanos, a partir de uma sondagem sobre o envolvimento e o interesse discente em relação aos mesmos. Também busquei detectar as oportunidades oferecidas pela escola para atender às necessidades infantis relacionadas à leitura.

\section{Descrição}

Quando cheguei à escola, fui procurar a diretora, que se colocou à disposição para conversar, juntamente com a professora da sala onde iria começar o estágio (pré A)

A diretora e a professora da classe fizeram comentários sobre o projeto, sugerindo uma reunião com os pais que, segundo a opinião, em comum, são bastante participativos em relação às atividades propostas aos alunos. Assim, ficou agendada uma reunião com os responsáveis pelas crianças para a próxima sessão, a fim de apresentar o projeto aos pais, solicitando, simultaneamente, a colaboração dos mesmos no encaminhamento do trabalho.

Tanto a direção quanto a professora da classe demonstraram muito interesse em colaborar com o projeto, colocando-se à disposição para o encaminhamento do mesmo. Ressaltaram que é uma proposta inovadora e de considerável importância para a escola e principalmente para o desenvolvimento dos alunos. $\mathrm{Na}$ verdade, propuseram uma possibilidade de continuidade do trabalho, futuramente, também, para as outras classes da escola.

Visitei a classe e me apresentei às crianças. Observei que o espaço reservado para o material de leitura: livros e gibis, em geral, chamado de "canto de leitura" da classe, apresenta o material disponivel e acessivel aos alunos, sendo acomodado em uma espécie de sapateira plástica com várias divisōes, suspensa na parede à altura das crianças. 
Expliquei aos alunos que gostava muito de ouvir e contar histórias, por isso estava fazendo um trabalho da minha escola (faculdade) sobre histórias infantis e que precisava da ajuda de todos.

As crianças mostraram-se ávidas para conversar. Algumas apenas observavam, outras disputavam a vez de falar. Uma das alunas (Alana), logo que me apresentei, disse: "- Você não vai perguntar, logo, o nosso nome?". As crianças queriam que eu já começasse a contar histórias naquele momento. Expliquei que primeiro gostaria de ouvir as histórias que elas mais gostavam e depois eu contaria as minhas

Ao sair, percebi que Nathan se destacava no grupo como participativa e muito espontâneo. Quando solicitei que no próximo encontro escolhessem uma história para contar para mim e para o grupo, terminei a frase dizendo " - Tá bom?" Mais do que depressa ele completou: " - Tá bom e tchau". A professora o repreendeu, explicando que era falta de educação falar daquela maneira. Comecei a perceber a relação de autoridade da professora e uma certa limitação à espontaneidade das crianças

\section{Considerações}

Percebi que a minha proposta de trabalho começou a esbarrar em alguns entraves. O espaço da classe do Pré não auxilia as atividades criativas e de expressão em geral. As crianças sentam-se em cadeiras enfileiradas, como as de Ensino Fundamental, diferentemente das crianças do maternal e jardim, que se sentam em mesas coletivas. Conversei com a diretora e com a professora sobre a questão do espaço e sua distribuição. Explicaram-me que existe uma cobrança muito grande dos pais em relação à alfabetização; por isso o espaço já se estrutura adequando as crianças para a realidade da primeira série. Percebi que este seria um primeiro obstáculo para o desenvolvimento do projeto, uma vez que apresenta como objetivo a sensibilização e o aprimoramento das relações infantis, a partir da livre expressão. Pedi permissão para que no próximo encontro realizássemos as atividades em outro espaço fora da sala regular. Solicitei a área onde os alunos têm atividades de Educação Fisica e judô. A direção concordou e a professora foi convidada a participar das sessōes de estágio, acompanhando e auxiliando no encaminhamento das atividades.

\section{Segundo dia $-6 / 8 / 98$ Objetivo}

Observar o comportamento e interesse das crianças enquanto os colegas contavam suas histórias. Também pretendia detectar a capacidade das crianças em elaborar histórias a partir de suas ilustraçōes, além de expor aos pais o objetivo do projeto a ser implementado, solicitando a colaboração de todos.

\section{Descrição}

Quando cheguei à sala de atividades, cumprimentei a professora e as crianças e expliquei que mudariamos de sala para começarmos o nosso trabalho com as histórias, pois dessa forma todos poderiam participar. 
O desenvolvimento das atividades deu-se sobre um espaço (tatame) destinado às atividades de judô. Formamos uma grande roda e foi proposto que cada um apresentasse, espontaneamente, a história escolhida para o grupo.

Algumas crianças escolheram livros de histórias para a apresentação oral e, posteriormente, desenharam - Thalita: "Eu nunca vou crescer" (Figura 1- Anexo: p. 207); Karen: "A vaca mimosa" (Figura 2- Anexo: p. 207); Vitória: "A superficie"-, outras preferiram falar sobre as histórias dos gibis - Eduardo, Alana e Nathan: "Cascão" (Figura 3- Anexo: p. 208). Um grupo de crianças não selecionou a história, como havia sido pedido. Outro grupo, embora tenha selecionado, preferiu apenas observar e não se manifestou favorável à exposição oral. Ao final de cada exposição dos colegas, todos batiam palmas.

A maioria das crianças mostrou-se muito interessada em contar as histórias escolhidas. Todas queriam falar ao mesmo tempo. Percebi que estavam eufóricas e desabituadas a participar deste tipo de atividade (fora da sala de atividades), principalmente no que se refere a esperar a vez de falar e ouvir - este foi mais um obstáculo detectado a ser trabalhado. A professora da classe confirmou que raramente propõe a saída da sala, pois as crianças ficam muito agitadas, com exceção da ida ao parque.

As crianças contaram as histórias a partir das ilustrações, embora algumas já estejam praticamente alfabetizadas. Muitas estendiam-se e repetiam as idéias, o que, aos poucos, levou os demais à dispersão e às conversas paralelas. A estratégia foi mudada para que o grupo não se desinteressasse comprometendo as próximas sessões. Combinamos que as demais histórias seriam apresentadas em dias posteriores, em pequenas sessões, para dar oportunidade a todos que quisessem falar, pois já estava quase na hora de ir para casa.

Algumas crianças apresentaram detalhes sobre as histórias que surpreenderam minhas expectativas. Dentre elas, vale a pena ressaltar Karen (A vaca mimosa) que a principio mostrou-se meio resistente à fala, mas depois empolgou-se e não deixava passar nenhum detalhe da história conforme as folhas iam sendo viradas. Victoria (A superficie) comentou que a joaninha estava embaixo do pé do menino, em seguida um colega questiona: " - Como você sabe que ela está lá, se não dá para ver?" Victoria argumenta: " - É que ele pisou em cima dela". Na verdade esta criança demonstra especial interesse para dar detalhes da história sobre cores e formas, além de agir com muita espontaneidade associando alguns fatos da história ao seu comportamento.

Em uma parte da história relativa ao "amor", ela levantou-se, sem dizer uma só palavra e foi sentar-se ao lado do Eduardo, que segundo a professora é sua grande "paixão". Alana (gibi do Cascão) demonstra grande vontade em participar, prolonga-se nos detalhes e acaba entediando o grupo. Repreende o grupo quando há interesse em olhar as ilustrações: " - Calma, Murilo, já vou mostrar!", " - Yuri, isso é palavrão!"

Os desenhos feitos pelas crianças, a partir de fatos e personagens da história, demonstraram que a classe conseguiu captar detalhes importantes sobre a mensagem do texto.

Ao final do dia, realizamos a reunião com os pais para a apresentação do projeto e sua proposta na escola. A maioria estava presente, com exceção dos pais 
de três crianças (Yuri, Larissa e Cristiane). Para estes, a professora faria um comunicado posterior, caso eu não estivesse na escola. A reunião dividiu-se em três momentos: apresentação da estagiária e do projeto; solicitação da colaboração dos pais nas tarefas de casa; convite à exposição das atividades realizadas pelas crianças. Os pais defenderam a importância das histórias e demonstraram interesşe, colocando-se à disposição para colaborar. Uma mãe comentou: " — Que bom que você escolheu esta classe!"

\section{Comentários}

A professora comentou que Gabriela estava muito preocupada, pois teria que contar a sua história. Segundo depoimento da mãe, ela é tímida demais. A professora reforça esta informação dizendo que a criança "mal" responde à chamada. Esta e outras informações auxiliaram-me a perceber que, devido à heterogeneidade da classe, precisaria reformular algumas estratégias de trabalho, sempre visando ao atendimento da especificidade de comportamento das crianças.

\section{Terceiro dia - 10/8/98}

Objetivo

Conhecer as noções das crianças sobre ORDEM e ORGANIZAÇÃO e leválas a refletir sobre o "porquê" da importância deste valor humano no cotidiano escolar, familiar e nas diversas situações da vida.

História infantil: A esquilinha caprichosa

Valor humano: ORDEM

\section{Descrição}

As crianças ouviram a música "No mundo da fantasia" (fita k7: O som dos baixinhos) antes de começarmos a atividade com as histórias:

\section{No mundo da fantasia nós sempre vamos estar}

Qual será a musiquinha que todos vamos cantar

Qual será a historinha que juntos vamos contar

Depois de ouvirmos a música, perguntei às crianças se sabiam o que era fantasia. O grupo fez alguns comentários sobre fantasia e realidade. Para a maioria, fantasia é "o que é de mentirinha", "o que não é verdade", "o que não acontece". A realidade, segundo as crianças, é "coisa de verdade", "o que acontece". Foram dados alguns exemplos da novela Torre de Babel, como o episódio da explosão do shopping que para muitos foi fantasia, para outros: "poderia acontecer de verdade." Para a maioria das crianças, as histórias têm coisas de verdade e, também, de mentirinha.

As crianças acompanharam a leitura da história, quiseram olhar de perto as ilustrações, desde a capa do livro. Houve comentários sobre o comportamento das personagens e das características de alguns fatos e objetos: esquilinha: 
"caprichosa"; coelhinha: "bagunçada"; motoneta: "que nem uma vespinha, moto"; espanador: "é pra limpar e tirar o pó"; pombinha: "voa rápido que nem um avião."

O grande interesse das crianças foi estabelecer a diferença entre a casa da coelhinha e a da esquilinha. Ficaram admiradas com a bagunça da coelhinha e riram de algumas ilustrações onde apareciam objetos em lugares completamente diferentes dos usuais: meia e sapato sobre a mesa, xicara no chão, teias de aranha nos cantos da casa

Algumas crianças captaram rapidamente a mensagem, demonstrando que a ordem é necessária. Outras ficaram mais impressionadas pelo fato de um menino malvado ter machucado a pombinha, que era amiga da esquilinha. Júlio chega a confundir Dona Coruja, uma personagem secundária da história, com o menino malvado, que na verdade não aparece na história, sendo apenas mencionado.

Todos ficam ansiosos para dar exemplos de coisas em ordem e arrumadas: na classe ajudar o colega a pegar o material e coisas que caem no chão; em casa: ajudar a limpar, varrer, lavar louça, ajudar o pai, a mãe, os irmãos sempre.

A reunião com as professoras de outras classes foi solicitada pela Direçãa e professores. Considerei o encontro bastante proveitoso, pois demonstrou que o projeto despertou interesse tanto nos professores de Educação Infantil (Maternal e Jardim) como nos de Ensino Fundamental ( $1^{a}$ a $4^{a}$ série). O corpo docente da escola já vem trabalhando com histórias; no entanto, percebi que as professoras gostariam de sistematizar e aprofundar esta proposta de aproximação à Literatura Infantil e aos Valores Humanos. Foi explicado que, devido ao tempo e às condiçães de implementação do projeto, inicialmente, só haveria possibilidade de acompanhar uma classe. mas que. futuramente, poderiamos pensar em estender o trabalho para outras classes. Para o momento, apresentei os objetivos do projeto e coloquei-me à disposição para as professoras interessadas em começar a estruturar o trabalho proposto em suas salas de atividades.

\section{Comentários}

Luana comentou que ninguém a ajudava na classe e, segundo a professora, - relacionamento desta criança com as outras é realmente difícil. Percebi que precisaria criar outras estratégias, além das previstas, para tentar ajudar a melhorar esta questão do relacionamento infantil, através dos valores inseridos nas histórias. Em contraposição, Victoria, ao final das atividades, deixou cair os cadernos no chão e todos quiseram ajudá-la a colocá-los em ordem. O grande desafio parece ser: como melhorar as relações de forma satisfatória para o consenso de um bemviver entre todos? Como o projeto proposto poderia ajudar as crianças neste sentido? Levei estas reflexões comigo, tentando pensar em algo diferente para a próxima sessão

\section{Quarto dia - 12/8/98 Objetivo}

Refletir e discutir sobre a estrutura das relações de ORDEM estabelecidas pelas crianças na escola e em casa. 


\section{Descrição}

As crianças pediram para cantar a música "No mundo da fantasia" , pois, segundo a professora, elas gostaram tanto da canção que não paravam de cantá-la, mesmo sem a minha presença na escola.

Após cantarem, fizeram a reconstituiçāo da história da sessão anterior, a partir das ilustraçōes. Lembraram de detalhes como o vestido da coelha, a casa da esquila em uma bonita árvore da floresta e caracteristicas de personagens. Thalita criou um personagem novo que não aparece na história: o filho da esquilinha. Segundo ela, ele iria nascer num próximo capítulo, na continuação da história. Deram, também, possíveis nomes à esquilinha e à coelhinha, já que na história işto näo é colocado. Para a esquilinha foram propostos os seguintes nomes: Claudia Perez, Sheila Carvalho, Gabriela (três indicações), Violeta, Jasmim.

Para a coelhinha: Leticia, Karen (duas indicações), Glaucia, Viviane.

Todos confeccionaram o espanador da esquilinha com penas coloridas restantes das atividades do dia do índio, palitos de sorvete e fita crepe, e levaram para casa suas produções (Fotos 1 e 2- Anexo: p.217).

O grupo mostrou-se mais interessado em participar das atividades propostas, especialmente nesta sessão, onde confeccionaram o espanador da história e puderam levar para casa. Segundo as crianças, elas iriam limpar as coisas de casa com o espanador igual ao da esquilinha ... e já começaram a fazer isso na classe, espanando as mesas

Observei a predominância de nomes de personagens populares como Carla Perez e Sheila Carvalho (dançarinas conhecidas e muito populares na ocasião) para as personagens da história, mas, ao mesmo tempo, a predominância de nomes de colegas da classe apreciados por todos (os mais cotados: Gabriela e Karen), outros nem foram mencionados. O nome da professora (Viviane) também foi lembrado

\section{Comentários}

Para minha surpresa, Gabriela, que raramente se pronuncia, entregou-me um presente: um desenho de cachorrinho da série dos Dálmatas. Diz apenas: "- $E^{\prime}$ pra você." Esta aproximação foi-me bastante gratificante nesta sessão. Fiquei refletindo sobre um possivel impacto e interesse devido à atividade proposta. Seria isto ou apenas um resultado natural decorrente da convivência? Mais um ponto a ser observado na próxima sessão...As observações, que me proponho fazer, parecem cumulativas e interligadas a cada encontro com as crianças. Parece que a cada dia elas me oferecem dicas para reflexão e discussão sobre a viabilidadø do projeto em questão.

\section{Quinto dia - 17/8/98 Objetivo}

Perceber qual a importancia da GRATIDĀO para as crianças e como concebem a questão sobre a ajuda ao outro.

História infantil: A formiga e a pomba

Valor humano: GRATIDÃO 


\section{Descrição}

As crianças mostraram-se animadas com a minha chegada. Fizeram perguntas sobre a nova história, queriam ver o livro e manuseá-lo.

Subiram para o salão cantando sozinhas a música "No mundo da fantasia".

A seguir, houve a leitura da história e simultânea participação das crianças fazendo perguntas e comentários a respeito dos fatos e personagens apresentadqs.

Enquanto contava a história, interromperam várias vezes observando detalhes nas ilustrações, prevendo acontecimentos: "- A formiguinha vai salvar a pombinha..."- Elas ficaram amigas para sempre"...(Cristiane). Todas pareceram bastante envolvidas com esta história e ao final cantaram, espontaneamente, a música "Pombinha branca", que algumas já conheciam.

Depois de contar a história, voltamos para a classe onde foi elaborada, pelas crianças, uma lista com nomes de colegas que gostariam de ajudar durante a semana. O cartaz com os nomes das crianças foi afixado na parede da sala de atividades, para as crianças consultarem quando precisassem lembrar.

\section{Comentários}

Percebi que houve repetição de alguns nomes, na lista afixada na sala de atividades, que todos os colegas queriam ajudar: Gabriela, Karen, Vitor, Letícia. Após uma conversa com as crianças sobre a necessidade de dividir a ajuda a todos os colegas, os nomes variaram um pouco, mas o predominio de alguns, mesmo assim, ocorreu... Outros quase não foram mencionados... Continuo buscando estratégias que possam auxiliar em um melhor relacionamento do grupo, através dos valores humanos apresentados nas histórias.

Sexto dia $-19 / 8 / 98$

Objetivo

Levantar reflexōes com as crianças sobre os vários tipos de ajuda que podemos dar às pessoas.

\section{Descrição}

As crianças subiram agitadas. Conversei explicando que era preciso. "ouvir" para que pudéssemos entender a história. Perguntei se todos gostariam realmente de ouvir a história ou se preferiam fazer outra coisa. Todos manifestaram-se positivamente a ouvir a história e a agitação foi superada, pelo menos naquele momento.

As crianças recontaram a história da sessão anterior a partir das ilustraçōes. Algumas antecipavam os acontecimentos antes mesmo da ilustração ser proposta. Muitas questionaram, completaram a fala dos colegas, outras acabaram confundindo situações que não estavam na histórla: "A formiga mordeu o braço do caçador" (Alana). Aliás, a figura do caçador foi bastante marcante para as crianças. Ele aparece como uma pessoa má, que não merece consideração e, segundo as crianças, "foi bem-feito para ele, a formiga ter mordido a perna dele..." 
As crianças fizeram comparações entre a ajuda da formiga e da pombinha, fazendo colocações sobre os vários tipos de ajuda prestados à família, à professora, aos colegas.

Também discutiram sobre as palavras "margem", "flutuando" e "navegando". As conclusões explicativas foram tiradas pelas próprias crianças, procurei apenas acrescentar algumas idéias quando necessário. Algumas explicações das crianças foram: "- Margem é quando é na beira da água"..."Flutuando é que nem ir boiando"..." Navegando é que nem o navio faz..."

A seguir, as crianças cantaram sozinhas a música "Pombinha branca", sem fita K7. Com a colocação da fita houve grande e maior animação e todos queriam dançar ao mesmo tempo em que cantavam. Propositalmente, fui passando várias músicas na fita, até que as crianças identificassem a da pombinha. Enquanto isso, dirigia algumas colocações ao grupo: " - Será que a pombinha foi embora?"..."Ela voou para outra fita ou ainda está aqui?".. As crianças acompanhavam as colocações, e as respondiam rindo bastante.

Aproveitei a música cantada sobre a pombinha para explicar a forma correta de uma palavra. As crianças pronunciavam "guspir". Expliquei que a forma correta era "cuspir". Depois da explicaçāo ficaram repetindo várias vezes a forma nova ensinada como se fosse uma grande novidade para o grupo.

Solicitei às crianças que lembrassem dos detalhes da história e que fizessem um desenho usando caneta hidrocor, giz de cera; lápis de cor e o que mais desejassem. A maioria colocou o seu próprio nome no sulfite e, também, o nome da história.

As crianças fizeram modelagem sobre fatos e personagens da história. Pediram cores diferentes para suas produçōes e depois posaram para as fotos, ao lado de suas atividades (Fotos 3 e 4- Anexo: p.217).

Os desenhos e as atividades com massa de modelar foram feitos com bastante entusiasmo pelas crianças. Todos queriam mostrar suas produções e serem fotografados. Expliquei que iriamos fazer uma exposição sobre o que estavam fazendo a partir das histórias. Cristiane quis saber o que era exposição. Explicamos e ela achou a idéia interessante, pois os pais iriam ver.

\section{Comentários}

Tenho percebido que, embora a proposta inicial tenha sido sentarmos em roda, as crianças procuram outras posições, à medida que vamos contando ou recontando as histórias: deitam-se de bruço, põem a mão sob o queixo para apoiar a cabeça, deitam-se de lado...Parecem sentir-se mais abertas e à vontade, entrando no mundo da fantasia. Talvez o próprio espaço esteja ajudando neste sentido.

\section{Sétimo dia - 24/8/98 Objetivo}

Discutir sobre as diferentes situações que envolvem CORAGEM e companheirismo e, também, refletir sobre a importância do "pensar" para resolver e solucionar problemas, encontrando possiveis soluções. 
História infantil: O pintinho Quiquiriqui

Valor humano: CORAGEM

\section{Descrição}

Houve entusiasmo das crianças ao ouvir a história. Algumas balbuciavam o final das palavras que eu pronunciava enquanto contava a história, como se fossem um eco da minha fala, demonstrando grande vontade de interagir no processo de contar

Muitas chegaram a me interromper curiosas: " - Como pode o ribeirinho caber no papo do pintinho se ele nem ficou gordo?" (Alana)..." - Como o pintinho engoliu o espinheirinho se ele nem se engasgou?" (Karen)... Outras completavam dando logo a resposta: " - É mágica!"...E acabaram convencendo os duvidosos com este argumento do mundo da fantasia. Isto, para mim, representou um avanço na proposta do projeto, pois as crianças aceitaram, como eu já havia previsto, as idéias oriundas do universo da magia e do faz-de-conta, incorporando, aos poucos, as mensagens contidas nas histórias infantis.

A maioria das crianças sentiu-se atraida por alguns versos da história que foram decorados, antes que eu terminasse a leitura: "Ribeirinho, ribeirinho, fica bem pequenininho, do tamanho de um grãozinho, e entra aqui no meu papinho." O mesmo aconteceu com a paredinha e com o espinheirinho.

As crianças acharam engraçadas os momentos em que o pintinho pedia para o ribeirinho, para o espinheirinho e para a parede sairem da frente para ele poder passar. Talvez pela repetição das situações inusitadas e, ainda, pela determinação e pretensão ou coragem de um simples e pequeno pintinho.

Observaram que o rei e o galo eram muito feios e bravos. Em contrapartida, encantaram-se com o pintinho. O ponto mais hilariante para as crianças foi quando li que o galo iria se aposentar. As crianças que não sabiam o que era "aposentar" foram orientadas por algumas que diziam: "- $\dot{E}$ quando a pessoa não tem mais que trabalhar...", outros achavam que era quando a pessoa ficava velha... Nathan completou: " - É quando a pessoa já trabalhou trinta anos!"

Após a leitura e discussão sobre coragem e companheirismo, a classe cantou com entusiasmo a música "Meu pintinho amarelinho". Levantamos alguns comentários sobre a importância do cantar sem gritar, respeitando os ouvidos dos colegas próximos e, também, os colegas das outras salas da escola, que estavam em atividades

As crianças criaram cenários sobre fatos da história com jogos de encaixe, relatando ao serem filmadas, o que haviam construido, reconstituindo a história (Fotos 5 e 6-Anexo: p.218).

A dobradura do pintinho foi feita a partir da elaboração de um cenário criado pelas crianças, inserindo o personagem principal em um dos episódios narrados na história.

\section{Comentários}

Percebi que Gabriela e Júlio mostraram o que produziram com prazer e quiseram ser filmados, o que nunca havia acontecido antes. Nathan e Yuri, com o 
Olhar parado e atento, não perdiam uma só explicação sobre a trajetória de coragem do pintinho. Ambos normalmente são bastante inquietos e dispersivos. Esta história parece ter atingido o ponto de interesse de muitas crianças, transformando suas próprias atitudes perante a classe. O mesmo aconteceu em relação ao comportamento de Luana e Alana, que se mostraram mais atentas e participativas com moderação, ou seja, participando com o grupo de forma mais organizada. Decorar os versos rimados da história pareceu dar ao grupo uma cumplicidade e companheirismo no recitar das palavras. Talvez seja esse um caminho que o grupo indicou-me para melhorar as relações entre as crianças.

Oitavo dia - 26/8/98

Objetivo

Reconhecer os laços de companheirismo entre as crianças, levando-as a refletir sobre a importância da SOLIDARIEDADE, da ajuda aos outros.

História infantil: A festa no céy

Valor humano: SOLIDARIEDADE

\section{Descrição}

As crianças fizeram comentários sobre situaçōes de coragem referentes à sessão anterior

A seguir, cantamos a música de entrada e, após a leitura da nova história, cantamos, também, a música da tartaruguinha. Comentamos sobre a importancia da solidariedade. Algumas crianças não conheciam esta palavra, as que a conheciam explicaram que é "quando a gente ajuda as pessoas." A explicação mais convincente foi extraida da própria história pelas crianças: "Foi que nem quando o Pai do céu ajudou."

Foi proposta uma atividade coletiva a partir de pinturas feitas com pincéiş e tinta colorida em cartolinas. As crianças dividiram-se em grupos com quatro participantes (Fotos 7 e 8-Anexo: p.218).

Depois de trabalharem com as tintas, propus ao grupo a brincadeira da tartaruga esperta. As crianças deveriam correr ao redor dos colchonetes enquanto a música estivesse tocando. Ao parar a música, as crianças deveriam deitar-se, rapidamente, de costas sobre os colchonetes, balançando pernas e braços ao mesmo tempo, como tartarugas espertas. A regra da brincadeira era respeitar o espaço do colega, sem passar por cima dos colchonetes, tomando cuidado para não machucar a pessoa ao lado, no momento de deitar-se.

As crianças participaram satisfatoriamente de todas as atividades propostas. Demonstraram especial entusiasmo ao cantar a música da tartaruguinha. Olhavam para o céu e ao ver os urubus sobrevoando diziam: "Olha a festa lá no céu, os urubus já estão indo..."

No entanto, na atividade sobre a tartaruga esperta, alguns não conseguiram seguir as regras propostas, nem tampouco as orientaçōes sobre solidariedade e respeito ao próximo. 


\section{Comentários}

Percebi que, embora as crianças tivessem discutido sobre a importância das regras da brincadeira, na prática tiveram dificuldade para executar o combinado. Constatei que talvez esta dificuldade fosse proveniente da fase de anomia colocada por Piaget, para crianças de 5 a 6 anos, quando apresentam comportamento contrário às regras do jogo, não seguindo regras coletivas. Pensei, também, na falta de oportunidade para expressāo, uma vez que raramente as crianças realizam atividades fora da sala de atividades. Em um momento oportuno, tentarei retomar esta questão para, aos poucos, amenizar esta dificuldade das crianças.

Nono dia $-31 / 8 / 98$

Objetivo

Identificar as noções das crianças sobre colaboração e trabalho coletivo e refletir com elas sobre a força do grupo.

História infantil: A galinha ruiva

Valor humano: PERSEVERANÇA

\section{Descrição}

O grupo demonstrou bastante entusiasmo pela história apresentada com sua respectiva música. Fizeram comentários paralelos durante a leitura da história: "- Nossa, como o porquinho é nojento!" (Ivã)..." - Eles foram até a casa da galinha?" (Alana)

bolo.

As crianças começaram a fazer diversos comentários sobre receitas de

Discutimos sobre situações em que podemos colaborar com as pessoas na escola, em casa e nos mais diversos lugares

Houve grande interesse em repetir as falas do patinho e do porquinho para a galinha ruiva: " - Eu, eu não...disse o porquinho"..." - Eu, eu não... disse o patinho"

As crianças riram bastante ao ver o porquinho sendo levado pelo cheiro go bolo, flutuando pelo ar, conforme as ilustraçōes do livro. Pediram para ver várias vezes esta passagem.

Perguntei às crianças se gostariam de fazer um bolo como o da galinha ruiva ou parecido com o dela. Nathan quis saber se iriamos fazer um bolo de chocolate. O grupo decidiu fazer um bolo de milho igual ao da história da galinha ruiva, no próximo encontro.

Combinamos que cada um iria colaborar trazendo algo para que pudéssemos fazer o bolo. A merendeira da escola iria nos dizer quais os ingredientes necessários e, assim, dividiriamos igualmente entre as crianças.

Murilo mostra-se mais solto para falar. Sentou-se ao meu lado na roda e fez algumas perguntas: " - É pra perguntar a receita de bolo pra mãe?"..." - É só o que lembrar, né?" 


\section{Comentários}

A cada encontro, tenho tentado incentivar as crianças a se abrirem mais, fazendo perguntas, aguçando o seu pensar... Comecei a sentir uma sutil diferença no comportamento de algumas crianças, principalmente nas que demonstravam, no inicio, certa dificuldade para estabelecer contato. Parece que a estratégia de trabalhar os valores humanos através das histórias começa a surtir alguns efęitos no grupo.

Por outro lado, o grande desafio continua sendo estabelecer o momento de falar e ouvir, e, ainda, o de aprimorar as relações interpessoais, dando a todas a oportunidade de expressão. Acredito que, desta forma, os valores humanos poderão ser sentidos com mais significado e profundidade pelas crianças.

Décimo dia - 2/9/98

Objetivo

Reforçar o valor da colaboraçāo, por intermédio de uma atividade prática desenvolvida por todos, sem exceção, na cozinha experimental.

Descrição

Neste dia, as crianças estavam tão ansiosas para preparar o bolo que acabaram batendo palmas quando eu cheguei. A professora comentou que elas não viam a hora de começar a fazer o bolo.

As crianças reconstituíram a história anterior a partir das ilustraçōes e fizeram comentários sobre as cartinhas que tinham levado para casa, endereçadas aos pais

Todas apresentaram interesse em falar sobre os ingredientes que haviam trazido de casa para fazer o bolo igual ao da galinha ruiva.

Queriam contar como a mãe fazia bolo em casa. Cada um falou sobre sua receita caseira

As crianças comentaram que Vinicius e Yuri eram que nem o porquinho $\theta 0$ patinho, pois não tinham trazido nada para colaborar com o bolo e que, portanto não deveriam comer. Expliquei que eles haviam faltado na sessão anterior $e$, mesmo quem não pudessem colaborar com os ingredientes, poderiam colaborar ajudando a mexer e a preparar a massa. Coloquei a decisão para o grupo e as crianças acabaram concordando em deixá-los comer com elas, mediante a colaboração dada por cada um no preparo do bolo.

Fizemos comentários sobre a divisão dos ingredientes entre os colegas que haviam faltado no dia anterior. O grupo concordou com a decisão coletiva.

O preparo do bolo contou com a ajuda da merendeira da escola que já havia sido avisada sobre a atividade. A massa foi feita na cozinha da escola. Cada um colocou o seu ingrediente para colaborar com a massa do bolo (Foto 9-Anexo: p.219). Viviane, a professora, colaborou misturando os ingredientes para a cobertura.

Enquanto a merendeira preparava a massa e as crianças ajudavam no que podiam, pedia ao grupo que me dissesse o nome dos ingredientes. Alana explicoume que sem o fermento o bolo não iria crescer, já que a Victoria tinha esquecido de 
levar este ingrediente. Acabamos pedindo emprestado na cantina da escola. Karen explicou que se não passasse margarina e depois a farinha na forma a massa iria grudar

Depois que a merendeira colocou a massa no forno, na presença de todøs, pedimos para que avisasse quando estivesse pronto, para que as crianças pudessem comer antes de irem embora.

Enquanto o bolo estava no forno, as crianças fizeram, na classe, uma pesquisa em revistas sobre coisas gostosas para comer e para beber. Montaram suas produções em papel sulfite.

$\mathrm{Na}$ atividade com recorte e colagem - coisas gostosas para comer - as crianças solicitaram que fossem incluidas, também, coisas gostosas para beber, o que foi aceito de imediato, pois o pedido representou um consenso do grupo.

Depois de pronto o bolo, fomos avisados e descemos para comer encerrando as atividades do dia.

As crianças repetiram várias vezes. Comeram com muita vontade e queriąm ainda mais. Algumas pediram para levar para casa, caso sobrasse... o que não aconteceu... (Foto 10- Anexo: p. 219)

Ao final das atividades do dia, Nathan comentou: "- Nada de parque hoje!... Queremos ouvir as histórias da tia Selma...Chega daquelas brigas horrivel!..."

\section{Comentários}

As colocações de algumas crianças dizem-me, de certa forma, que eles tệm apreciado as sessões e as histórias. No entanto, ainda tenho dúvidas se estou conseguindo atingir, realmente, a proposta do projeto, em relação ao significado e aplicação prática dos valores humanos. Talvez esta seja apenas uma primeira etapa, sendo as outras alcançadas a longo prazo.

Ao longo das sessões, tenho percebido que as crianças me trazem respostas, envolvendo somente comportamentos e atitudes positivas sobre as tarefas propostas para casa, talvez para corresponder às minhas expectativas de adulto e me agradar deliberadamente. Tenho refletido bastante a respeito desta situação nas sessões de supervisão. Na verdade, minha intenção é descobrir qual é a concepção de valores que elas têm e não ser agradada por ser adulta ou porque gostam de mim. Por esta razão, resolvi abolir as tarefas de casa, previstas no plano inicial do projeto, a partir dessa sessão, na tentativa de perceber o que as crianças, realmente, sentem e pensam.

\section{Décimo primeiro dia $-8 / 9 / 98$ Objetivo}

Refletir com as crianças sobre a importância de dizer "por favor" às pessoas (consideração e RESPEITO mútuo).

História infantil: Por fayor

Valor humano: RESPEITO 


\section{Descrição}

As crianças mostraram-se bastante interessadas pelo novo e grande livro, intitulado "O livro das virtudes para crianças". Expliquei que ali havia uma porção de histórias para crianças. Queriam que eu lesse todas. Discutimos sobre a questão do curto período de tempo que dispúnhamos, sendo impossivel, naquele momento, contar todas as histórias que queriam. Elas concordaram que eu contasse, inicialmente, as que já estavam previstas no projeto (Por favor / Hércules e o carreiro) e, posteriormente, contaria as outras.

Após a música de entrada e leitura da história, as crianças fizeram várias perguntas sobre o boneco "por favor". Queriam saber se ele realmente morava na boca de todas as pessoas. Expliquei que dependia da consideração, do respeito e da educação que as pessoas tinham em relação aos outros.

Houve grande interesse em apresentar cenas que mereciam o acréscimo do "por favor": em casa, na escola e em todos os lugares.

Cada criança, de olhos fechados, retirou, de uma mala surpresa, um fantoche para representar situações em que se pudesse usar "por favor", complementando, ainda, com "muito obrigada". Comecei incentivando as crianças, iniciando um diálogo, e, aos poucos, elas próprias deram nomes aos seus fantoches (Joaninha, Fadinha, Rafaela, Roberto Carlos, João etc) e foram criando diversas cenas relacionadas com a história. Depois, trocaram os bonecos entre si, de acordo com o interesse de cada um.

As crianças colocaram seus nomes em um abaixo-assinado (Figura 4Anexo: p. 209) em defesa do boneco "por favor". Discutimos que seria um documento de toda a classe, confirmando a importância de se ter o boneco "por favor" morando em nossas bocas

O grupo desenhou com muito interesse o boneco "por favor" (Figura 5Anexo: p. 209) e todas as crianças disseram que iriam colaborar com muitos "por favor", também, em casa. Para a próxima sessão, contariam as situações em que dissessem "por favor" em casa, o que os deixou muito envolvidos e motivados.

\section{Comentários}

O grande desafio continua sendo fazer alguns entenderem a importância de esperar o outro falar e, também, saber ouvir. Algumas crianças como Alana e Cristiane, por exemplo, disputam a fala, o material e até o lugar ao meu lado. Tenho tentado trabalhar estes fatos democraticamente, mas intervindo, quando necessário, para estipular limites, evitando criar situações de conflito entre algumas crianças mais intempestivas e, ainda, com muita dificuldade para seguir e respeitar regras no grupo.

Percebi que esta história surtiu bastante efeito nas crianças. A principjo, pensei na possibilidade de elas estranharem o novo livro; no entanto, elas o aceitaram de imediato, como uma novidade bem-vinda e já começaram a utilizar o "por favor" com a professora: " - Posso ir ao banheiro, por favor?"

Leticia e Luana pediram para mexer no livro. Nathan conseguiu ler o nome do livro e comentou com a classe. Pediu para que depois eu contasse a história da estrelinha. Todos se interessaram pela grande quantidade de textos e ilustraçōes presentes em um só livro. Esta foi a grande atração do encontro. 


\section{Décimo segundo dia - 9/9/98 Objetivo}

Refletir e discutir sobre a importancia do ESFORÇO de cada um para conseguir realizar o que deseja.

História infantil: Hércules e o carreiro

Valor humano: ESFORÇO

\section{Descrição}

Inicialmente, as crianças fizeram comentários sobre a tarefa de casa da sessão anterior. Todos apresentaram relatos sobre situações em que usaram "por favor" e "obrigado(a)

A seguir, foi feita a leitura da história do dia. Discutimos sobre a importancia do esforço para conseguirmos atingir o que queremos. As crianças deram exemplos de situaçōes em que haviam se esforçado: guardar brinquedo, fazer tarefas em casa etc. A maioria das crianças já havia escutado falar sobre Hércules. Comentaram que ele era um homem muito forte.

Assistimos à fita de vídeo sobre Hércules. Pedi às crianças que observassem se a história da fita era semelhante, ou não, à história que eu acabara de ler no livro

Muitas conheciam a fita de video que levei para o grupo assistir; no entanto, todas demonstraram interesse em assisti-la, dizendo que Hércules "era um Deus muito forte.

Expliquei ao grupo que precisariamos prestar atenção para entender a história. Os que já conheciam a fita pronunciavam, simultaneamente, as falas dos personagens, dando a impressão de que já haviam decorado alguns trechos da narrativa

As partes mais atrativas da história para as crianças foram as cenas referentes ao humor dos personagens e, também, às situaçōes envolvendo música. As cenas em que Hércules demonstra sua força para ajudar as pessoas e salvá-las do perigo conseguiram sensibilizar bastante as crianças, que torciam pela vitória do herói

Embora o objetivo tenha sido trazer ao grupo mais uma opção de acesso às histórias, para discutirmos o valor do ESFORÇO, percebi que algumas crianças não conseguiram concentrar-se por mais de trinta minutos. Por isso, quando comecej a observar a dificuldade, pedi para a professora permissão para que as crianças assistissem à segunda parte da fita no dia seguinte, já que o horário da saída também se aproximava. A professora concordou e assim foi feito. Explicamos às crianças que veriam a segunda parte da história no dia seguinte, pois estava na hora da saida.

\section{Comentários}

Observei que houve interesse e envolvimento das crianças; no entanto, acredito que algumas compreenderiam melhor a essência da história, se a fita fosse de menor duração, garantindo o seu limite de concentração. 


\section{Décimo terceiro dia - 14/9/98 Objetivo}

Discutir com as crianças sobre as diferenças e semelhanças entre a história apresentada no livro e a apresentada na fita de vídeo, enfocando, em ambas, o valor do ESFORÇO para conseguirmos o que desejamos.

\section{Descrição}

Quando cheguei à escola, a coordenadora avisou-me que a professora da classe havia faltado. Pediu que eu trabalhasse com as crianças normalmente, pois estavam com uma professora substituta e já haviam perguntado por mim.

Fui para a sala de atividades. As crianças estavam brincando com jogos de encaixe. Cumprimentei-as e elas pediram para que eu contasse histórias. Retomamos a história da sessão anterior já que não haviamos completado as atividades propostas. Algumas crianças pediram para ver a fita sobre Hércules, pois haviam faltado no dia anterior. Expliquei que depois iria pedir à professora que colocasse a fita, novamente, para aqueles que desejassem assisti-la, mas que naquele dia não seria possivel, pois precisávamos terminar as nossas atividades sobre as histórias. Cristiane quis saber o que era atividade. Expliquei-lhe que era uma espécie de trabalho que sempre costumávamos fazer na escola: desenho, recorte, pintura etc.

Perguntei às crianças sobre as diferenças e semelhanças entre o Hércules da história do livro e o da fita de video. Alana respondeu que "eles eram que nem irmãos, muito fortes... O do livro era um homem da selva e o do vídeo era que nem um Deus... As crianças comentaram que o Hércules das duas histórias era esforçado para conseguir as coisas que queria

Pedi para que fizessem um desenho sobre a história e que montassem a carroça que aparece na história do livro com palitos de sorvete. Os desenhos foram variados, apresentando muitos detalhes sobre os fatos narrados (Figura 6Anexo: p. 210). Sugeri uma montagem de carroça, mas informei que as crianças poderiam criar suas próprias carroças; no entanto, se quisessem, poderiam aproveitar a minha sugestão ou também as de outros colegas da classe. Todas as crianças colocaram o nome da história do livro: "Hércules e o carreiro" e também seus próprios nomes.

\section{Comentários}

Senti as crianças meio dispersivas, talvez pela falta da professora. Apesar de trabalharem com entusiasmo, percebi que algumas não se interessaram tanto por esta história como as anteriores. Senti que muitas fixam mais sua atenção na narrativa quando há mais ilustrações acompanhando o texto. Essas crianças gostam de ver as figuras e de fazer comentários, dando detalhes e completando com exemplos. Muitas envolveram-se bastante com a montagem da carroça, outras com a possibilidade de poder usar caneta hidrocor e lápis de cor para colorir. Percebo, a cada sessão, que a variedade de material oferecido para a realização das atividades, também, motiva muito as crianças. A questão da SOLIDARIEDADE e da COOPERAÇÃO tem aparecido com freqüência durante as atividades. As crianças emprestam mais o material aos colegas. Trocam cores diferentes de caneta $\theta$ tubos de cola, o que antes não acontecia com naturalidade, e respeitam os pedidos de 
"por favor." Começo a perceber que histórias anteriores têm fornecido, à classe, subsidios positivos para atitudes tomadas no decorrer das atividades desenvolvidas em histórias posteriores.

\section{Décimo quarto dia - 15/9/98 Objetivo}

Refletir com as crianças sobre a importância da COOPERAÇÃO, buscando exemplos para ilustrar a força do grupo na realização do que desejamos.

História infantil: A formiguinha e a neve

Valor humano: COOPERAÇÃO

\section{Descrição}

Cheguei à escola quando as crianças estavam tomando lanche. Elas me viram e começaram a me chamar. Fui ao encontro delas no refeitório e expliquei que depois do lanche conversariamos melhor para não atrapalhá-las.

Após o lanche as crianças foram para a classe. Teriam atividade de Inglês. Depois dessa atividade, fui para a sala. Achamos melhor ficar lá, naquele dia, excepcionalmente, pois estava chovendo muito e, também, estava muito frio no salão onde costumávamos conversar sobre as histórias. Tiramos essa concluș̄â com o grupo, pois algumas crianças e, inclusive a professora, estavam muito resfriadas. Algumas crianças não gostaram muito da idéia, mas acabaram compreendendo o cuidado que estávamos tendo em relação aos colegas e à professora. Combinamos que assim que melhorasse o tempo, voltariamas a conversar sobre a história no lugar de costume.

As crianças viram a capa do livro da nova história e foram lendo: "A formiguinha e a neve". Nathan, Ivã e Karen nem vacilaram para ler...O primeiro comentário que fizeram foi: "Nossa, que formiga feia!" (Ivã). Perguntei se já haviam ouvido alguma outra história sobre formiga e as crianças imediatamente comentaram que a outra história era sobre a "Formiga e a pomba". Murilo completou dizendo que "a outra formiga era vermelha e mais bonita do que a dessa história que era preta e feia."

À medida que lia a história, as crianças se antecipavam prevendo o que iria acontecer: "Agora vai aparecer o cachorro" (Murilo); "Nossa, que rato grande!" (Alana)... "Ele parece grande porque está perto da formiga" (Ivã).

Victoria queria saber se era história de medo. Quando apareceu a figura da morte na história com um traje preto, Ivã comentou: "Nossa, como a morte é ridícula "...As crianças acabaram rindo. No entanto, ficaram muito curiosas querendo ver a figura de Deus no momento em que a formiga começa a pedir sua ajuda olhando para o céu. Ficaram admirados com a beleza da Primavera: "Nossa, como ela é linda "...(Nathan). Perguntei se sabiam quem era a Primavera e as crianças disseram que "era quem trazia as flores."

Depois dos comentários feitos sobre a história, cantamos a música da formiguinha. As crianças adoraram e pediram para cantar várias vezes, acompanhando com gestos. 
A seguir, pedi às crianças que fizessem um desenho sobre a história que havíamos acabado de ouvir. Muitas capricharam nos detalhes e me contaram pormenores sobre os personagens. Assinalei nos desenhos das crianças o que me contaram sobre suas produções. As ilustrações mais marcantes foram: a formiguinha, a neve, o homem velho, a morte, o cachorro, a primavera, as nuvens, o sol, o gato entre outros.

Quando terminaram os desenhos, perguntei às crianças se as pessoas podiam ser cooperativas e trabalhadeiras como eram as formigas. As crianças concordaram, afirmando que já haviam observado como "as formigas trabalham e andam sempre em fila carregando a comida para a casa delas". Depois dessa reflexão, recortaram bonecos cooperativos, colando-os no verso da folha em que haviam feito o desenho sobre a história. As crianças sempre pedem para desenhar atrás da folha e considerei uma boa idéia colar e complementar os bonecos cooperativos no verso, pois acabou enriquecendo a mensagem da história. Pediram para acrescentar detalhes nos bonecos e incentivei-as dizendo que poderiam fazer o que quisessem. Algumas fizeram observações muito interessantes sobre suas produções

\section{Comentários}

As crianças gostaram bastante da história. Pensei que fossem indagar sobre a morte e já estava me preparando para isso; no entanto, nem tocaram no assunto. O que mais me chamou a atenção sobre as observações dos desenhos foi o fato de Alana me dizer que um de seus bonecos estava triste porque os outros dois não queriam dar a mão para ele... E sua colagem foi exatamente essa: dois bonecos juntos, de mãos dadas e um terceiro separado e mais distante (Figura 7 Anexo: p. 211). Percebo como as crianças nos dão pistas sobre o seu pensar e sentir (Figura 8- Anexo: p. 211). Alana, de certa forma, ainda continua sendo rejeitada em muitas atividades pelo grupo. Depois da história do "por favor", parece que consegue se integrar um pouco mais com os colegas, mas, mesmo assim, observo que, no fundo, deve sentir-se um pouco distante do grupo. Seu comportamento é muito ansioso, mal consegue ficar sentada ou desenvolver as atividades propostas sem falar alto e monopolizar a palavra, não dando a vez para os colegas. Talvez isso a afaste das outras crianças. Cristiane chegou a afirmar que "ela era muito chata, pois não deixava ninguém falar." Continuarei insistindo neşsa questão da integração e aproximação do grupo. Por outro lado, Alana parece ter grande necessidade de se sentir aceita e útil: sempre se oferece para levar o meu material, diz que sou que nem do Pré e ofereceu-me o número de seu telefone para ligar para ela no dia do seu aniversário ou, então, no domingo que é mais fácil...Carrego comigo mais reflexões sobre como ajudar essas crianças a serem mais felizes, através das mensagens que levo para elas a cada sessão, capazes de melhorar e, até mesmo, modificar suas atitudes no grupo.

\section{Décimo quinto dia - 16/9/98 Objetivo}

Discutir com as crianças sobre a importância da força de vontade e a INICIATIVA para realizar tarefas, mesmo que seja preciso tentar várias vezes até conseguirmos. 
História infantil: Os três porquinhos

Valor humano: INICIATIVA

\section{Descrição}

Cheguei à classe e as crianças estavam despedindo-se da professora de Inglês. Quando me viram, perguntaram se eu iria contar a história dos Três Porquinhos...A professora explicou-me que eles já sabiam sobre a história do dia, pois havia mandado um bilhete pedindo folhas secas às mães, conforme eu havia solicitado. Minha intenção era fazer uma simulação da palha usada em uma das casinhas dos três porquinhos, com folhas secas.

Como o tempo continuava chuvoso e muito frio, combinamos ficar na sala, mas algumas crianças queriam subir mesmo assim, demonstrando grande interesse para mudar de ambiente. Expliquei que algumas estavam resfriadas e que precisávamos respeitar a saúde de todos.

Cantamos a música de iniciação das atividades e depois contei a história dos Três Porquinhos. Algumas crianças já conheciam a história e se antecipavam, rapidamente, tentando contar cenas posteriores. Pedi para quem conhecesse o livro fazer segredo, até que eu contasse toda a história; assim, as outras crianças poderiam aproveitar uma parte da história de cada vez, devagar e sem pressa...

Durante a história, as crianças demonstraram grande simpatia em relação aos três porquinhos e torciam para que se saíssem vitoriosos a cada situação. A o contrário, em relação ao lobo, fizeram um coro de "bem-feito, bem-feito" quando teve seu rabo todo chamuscado ao cair pela chaminé e depois ser lançado como um foguete para o céu. As crianças riram muito às custas do lobo e disseram que ele merecia isso porque era muito mau para os três porquinhos.

Alana disse que "era que nem o porquinho Bolachão..." A professora comentou que ela se achava muito gorda e que isso a incomodava muito.

Depois dos comentários sobre a história, as crianças fizeram as casas construidas pelos três porquinhos, usando folhas secas para representar a casa de palha, pedrinhas de aquário para representar a casa de pedra e cal e palitos de fósforo para representar a casa de madeira. Todos desenharam e pintaram desenhos sobre a história complementando-os com a colagem dos materiais mencionados

As crianças demonstraram bastante interesse no decorrer da atividade. Contaram-me sobre as coisas que haviam desenhado. Luana empolgou-se com a cartolina que usamos para fazer o desenho e colagem: "Olha, é folha de papelão..." Expliquei que aquela folha era cartolina. Outros se entusiasmaram em poder usar pedra para colar. Eduardo perguntou-me sobre as pedrinhas. Disse-lhe que havia comprado em uma loja que vendia materiais para aquário. As crianças acharam engraçado o fato de eu comprar pedras...Eduardo completou que "gostava muito de peixinhos e que tinha um aquário em sua casa". Ele demonstra ter um grande senso de humor. Quando perguntei-Ihe se já havia colado suas pedrinhas disse-me: "Sim, muchacha!" Parecia alegre enquanto realizava sua atividade.

Alana colou tantas folhas secas em seu desenho, que mal se podia ver o contorno da casa. Comentou que sua casa pareceria um "grande ninho de passarinho." 
Em geral, todas as crianças tentaram fazer a atividade proposta com grande entusiasmo. Algumas desenharam mais detalhes sobre a história, outros preocuparam-se mais com a colagem dos materiais oferecidos (Fotos 11 e 12Anexo: p. 219).

\section{Comentários}

Descobri que algumas situações vivenciadas pelos personagens abrem possibilidades para a auto-expressão das crianças, comprovando o que tento demonstrar no projeto em discussão.

Quando Alana disse-me que "era que nem o porquinho", senti uma certa angústia em sua voz ou, talvez, um desabafo. Ao término do dia, como sempre tem acontecido ultimamente, pediu para carregar minha bolsa. Disse-lhe que estava pesada e que ela estava forte tanto quanto Hércules, com muitos músculos. Alana comentou que "iria fazer ginástica para não ficar gorda que nem o porquinho Bolachão." Não havia comentado isso antes. Lembrei-me do comentário que a diretora da escola havia feito certa vez, dizendo que ela era a filha mais velha, tendo dois irmāos menores de quatro e dois anos. A māe havia comentado que Alana estava fazendo regime para emagrecer e que "não podia comer uma série de coisas..." Fiquei refletindo sobre sua ansiedade e falta de integração em relação aos colegas da classe. Será que o seu comportamento poderia ser reflexo desse desconforto em relação à sua auto-imagem? Como seria para uma criança de cinco anos ser proibida de comer todas as guloseimas deliciosas que a permeiam e dão cor e vida à infância? Levei essas indagações comigo tentando encontrar caminhos para auxiliá-la no ajustamento intra e interpessoal, mesmo sabendo da dificuldade deste intento... Senti-me, também, bastante impotente neste processo que envolve questões familiares e considerando, ainda, o pouco tempo que teria de contato com esta criança até o final das sessões de estágio...Mas, mesmo assim, tentaria fazer o que estivesse ao meu alcance, buscando caminhos diversificados para, pelo menøs, amenizar certas dificuldades ou semear algumas reflexões positivas e facilitadoras para a vida de Alana.

\section{Décimo sexto dia $-17 / 9 / 98$ Objetivo}

Mostrar como nos sentimos ao nos colocarmos no lugar do outro, refletindo com as crianças sobre o PERDÃO e a importância de tentar compreender o outro. Pretendia fazer as crianças perceberem que as pessoas podem modificar-se, arrepender-se e mudar de atitude. Por isso, a história lida e discutida neste dia foi Os três lobinhos e o porco mau, na tentativa de levar o grupo a refletir sobre o inverso da história do dia anterior: Os três porquinhos (e o lobo mau...).

História infantil: Os três lobinhos e o porco mau

Valor humano: PERDÃO

\section{Descrição}

Quando cheguei à escola, a diretora informou-me que a professora da classe havia faltado. Disse que havia uma substituta com as crianças e que conversaria com ela para explicar sobre a minha entrada na sala. 
Apresentei-me à professora e expliquei-lhe sobre o meu projeto de estágio. As crianças pediram para subirmos ao salão, pois o tempo havia melhorado. $E$ assim foi feito conforme haviamos combinado na sessão anterior.

Todos cantaram a canção de entrada. Depois contei a história do dia.

Comentei com as crianças se sabiam o nome da história do dia, mostrandothes a capa do livro, e Nathan conseguiu ler o nome da mesma: "Os três lobinhos e o porco mau"

Perguntei se a história que iria ler era igual àquela do dia anterior e Thalita, mais do que depressa, disse: "- Não, ela é ao contrário."

Cristiane quis sentar-se ao meu lado na roda. Parecia querer contar comigo a história, tentava falar junto as frases, empolgava-se...As crianças ficaram admiradas com os materiais e palavras apresentadas na história. Queriam saber o que era betoneira, concreto, britadeira...Fizemos alguns comentários sobre suas dúvidas e todos obtiveram respostas para suas perguntas.

Quando apareceu o canguru no início da história, Alana disse que conhecia aquele animal que "tinha uma bolsa na barriga" e se pôs a imitar o canguru pulando no lugar. Letícia disse que o rinoceronte "tinha um chifre no nariz..." Alguns comentaram que o castor "parecia com a esquilinha da outra história." Ninguém sabia o que era o flamingo e ficaram surpresos ao descobrir que era uma ave, após olharem a ilustração

As crianças mostraram-se impressionadas com a malvadeza do porco mau. Não se conformavam com suas idéias para destruir as casas dos lobinhos.

O trecho que mais os surpreendeu foi quando o porco mau aspirou o aroma das flores que amoleceu o seu coração, transformando-o em um porco bom. Nathan, nesse momento, disse que "tinha gostado muito daquela história."

Perguntei às crianças se achavam que o porco deveria ser perdoado pelos lobinhos. Todos foram unânimes em dizer que "o porco merecia ser amigo dos lobinhos porque ele agora era bom e tinha se arrependido."

Depois da história, as crianças fizeram a casa de flores dos lobinhos (dobradura) e desenharam cenas e personagens que mais gostaram. Contaram-me sobre detalhes de seus desenhos. Karen desenhou notas musicais saindo da boca dos lobinhos e disse: "- Eles estão cantando..." (Figura 9- Anexo: p. 212). Alana disse: "- O coração do porco está com gotinhas porque ele está se derretendo porque cansou de ser mau." (Figura 10- Anexo: p. 212). Júlio comentou que "o cadeado da casa dos lobinhos era de metal." A maioria das crianças desenhou os três lobinhos, um de cada cor (preto, cinza e branco) e o porco com um grande coração. Eduardo pediu para que eu escrevesse em seu desenho: "O porco bem..." Perguntei se era bem ou bom e ele reforçou que era mesmo "bem". E assim foi colocado... Thalita e Yuri pediram para fazer a porta da casa com palito de sorvete. Nathan preferiu desenhar muitas flores e pediu para que eu escrevesse "As flores". Luana tinha algumas figuras de flores e aproveitou para decorar a sua casa, colando-as (Fotos 13 e 14- Anexo: p. 220).

Em geral, todas as crianças mostraram-se interessadas pela atividade proposta. Ao final da atividade, pediram para olhar o livro, manuseando-o com 
prazer. Avisei que no próximo encontro levaria o livro, novamente, para quem quisesse vê-lo melhor.

\section{Comentários}

Percebi como as crianças são justas e rigidas no julgamento que fazem em relação à questão do bem e do mau. Torcem sempre por um final feliz e vibram pelos personagens mais sofridos para que consigam vencer. Ficaram extasiados com a mudança repentina do comportamento do porco e demonstraram que acreditam na transformação das pessoas, dando-lhes uma segunda chance. Já vinha trabalhando o valor humano PERDÃO sob a nomenclatura do "Ele (a) está arrependido (a).."., nas situações de conflito na classe (Alanal Luanal Cristiane/ Nathan/ Yuri) e estava dando resultado, mostrando uma sutil melhora no comportamento das crianças. Agora esse valor foi claramente reforçado na mensagem da história e parece ter sido muito bem aceito pelas crianças.

\section{Décimo sétimo dia - 21/9/98}

Objetivo

Aproveitar o interesse das crianças sobre a AMIZADE, aprofundando este valor humano por intermédio das histórias apresentadas

Histórias infantis: A de amigo e Amigos

Valor humano: AMIZADE

\section{Descrição}

Quando cheguei à sala, as crianças pareciam contentes. Alana disse que "eu estava bonita." Subimos ao salão, cantamos a música inicial e também a da Primavera. relembrando a história anterior dos três lobinhos e o porco mau (a casa de flores). Fizemos comentários sobre o dia da árvore e sobre a chegada da Primavera.

Apresentei o livro da nova história para as crianças. Nathan e Ivã leram o titulo rapidamente: A de Amigo. A história foi escolhida, propositalmente, sem texto, para captar das crianças suas idéias sobre o valor da AMIZADE. Embora as crianças contribuissem para explicar trechos da história, algumas destacaram-se dando detalhes e pormenores: é feio..."

Alana: "Ele está triste porque ninguém quer ser amigo dele. Acham que ele

Nathan: "Ele sonha toda noite querendo achar um amigo de verdade!"

Ivã: "Ele nem percebeu que a borboleta gostou dele porque ela pousou nas costas dele."

Cristiane: "Depois eles ficaram amigos para sempre..." letras.

Depois desta história, as crianças pediram para contar outra que tivesse Apresentei a história chamada Amigos. 
As crianças acharam interessante e divertido três personagens tão diferentes serem amigos de verdade. Quiseram que eu repetisse várias vezes o nome dos personagens: O porco Valdemar, o galo Juvenal e o ratinho Frederico.

O grupo permaneceu atento durante o transcorrer da história. Algumas crianças deitaram-se apoiando a mão no queixo. Parecia que não queriam perder nenhum detalhe da narrativa. Outras faziam perguntas e observações:

Ivã: "Este desenho é igual ao da capa.." (cena no meio do livro).

Alana: "A Luana e a Gabriela são minhas amigas, mas não dividem nada comigo." (cena da divisão das cerejas entre os amigos).

$\mathrm{Na}$ cena em que os amigos acabam de comer e precisam ir ao matinho, as crianças afirmaram que eles só precisavam descansar. Achei interessante esta colocação coletiva do grupo. Ninguém no grupo mencionou a hipótese de eles terem ido satisfazer necessidades biológicas naturais, talvez isso tirasse um pouco da magia da cena. Refleti sobre essa possibilidade, afinal foi uma afirmação muito forte das crianças, sem dar margem a qualquer outra alternativa... As crianças se comoveram nas cenas em que os três amigos sonhavam juntos, sempre unidos, até no sonho... Conversamos bastante sobre a importância da AMIZADE e as crianças demonstraram interesse em falar a respeito desse tema.

No final da narração, pediram para eu contar sobre a autor que escreveu a história. Ficaram admirados pelo fato de Helme Heine morar tão longe, lá na Alemanha.

Todos demonstraram interesse em olhar os livros e manuseá-los. Propus que voltássemos para a sala de atividades. Todos queriam ajudar a carregar meus pertences: pasta, livros, bolsa etc... Tentei dividir a ajuda democraticamente - cada um levou um objeto - (afinal o valor humano trabalhado era a AMIZADE e o companheirismo...), para não criar atritos por excesso de gentileza comigo..

A seguir, fomos para a sala. Expliquei às crianças que após ouvir histórias sobre AMIZADE, elas mesmas poderiam criar suas histórias, construindo seu próprio livro. E assim foi feito. As crianças tiveram opção para escolher inclusive a cor de sulfite que gostariam de usar (rosa, azul, verde, amarelo). Essa possibilidade de escolha causou grande entusiasmo nas crianças. Alguns pediram o livro para "ver de perto" os desenhos e acabaram colocando a folha sobre os desenhos que mais lhe agradaram.

Ao final da sessão, ficaram felizes em mostrar seus livros, embora apenas algumas crianças tenham conseguido finalizar suas produções. Propus a elas que continuassem a atividade no próximo encontro. $E$ assim foi feito.

\section{Comentários}

Senti bastante interesse da classe em relação a este valor humano: AMIZADE (subvalor do valor central AMOR). Embora, inicialmente, este tema não estivesse incluido no projeto, percebi que seria bem aceito pelo grupo e, também, considerei que a mensagem ajudaria no relacionamento coletivo da classe. Esperava que o grupo refletisse mais sobre a questão da integração de todos e que alguns comentários ou queixas fossem feitos neste sentido. Realmente assim aconteceu. Alana foi uma das primeiras a se manifestar. Sua posição na classe foi por ela mesma diretamente relacionada às personagens da história. Fica cada vez 
mais claro para mim que as crianças se expressam mais livremente através das comparações que estabelecem entre elas e os personagens das histórias. Para o educador, este é um grande filão para o planejamento das atividades a serem trabalhadas com as crianças. São dicas imprescindiveis para o aprimoramento do processo ensino-aprendizagem.

\section{Décimo oitavo dia - 22/9/98 Objetivo}

Reforçar as idéias sobre AMIZADE e companheirismo da sessão anterior.

\section{Descrição}

Quando cheguei à sala, as crianças receberam-me cantando a música "Amigos", das Chiquititas. Queriam saber se contaria histórias novas. Expliquei que haviamos combinado terminar os livros do dia anterior.

A maioria das crianças optou por reconstruir a história "Amigos", outros em minoria escolheram "A de Amigo". Alguns pediram o livro para copiar os desenhos que mais gostaram. Letícia pediu para escrever algumas palavras na lousa para a sua história: Tchau, o porquinho e o lobinho. Ivã disse que "já tinha visto a palavra 'tchau', no final de uma história."

As crianças pediram para que eu escrevesse a história para os seus desenhos. Contaram detalhes e depois mostraram aos colegas da classe: Luana, Júlio e Victoria passaram de mesa em mesa, mostrando com orgulho suas produções. As demais preferiram mostrar sua obras sentadas (Fotos 15 e 16Anexo: p. 220).

Alana disse que "iria escrever tantas letras que nem sobraria espaço para o desenho..."E realmente fez isso, demonstrando que está praticamente alfabetizada.

Jessica desenhou claramente cenas do personagem solitário pensando ( $A$ de Amigo), fazendo balōes idênticos aos demonstrados na história.

A cena mais marcante da história para as crianças parece ter sido a da capa, onde aparecem os três amigos andando de bicicleta. Quase todas as crianças desenharam esta cena ou parte dela (Figuras 11 e 12- Anexo: p. 213). histôrias.

Algumas crianças (Eduardo e Ivã) escreveram "fim", no término de suas

Depois da elaboração dos livros, expliquei às crianças que as atividades que estavam fazendo sobre as histórias seriam mostradas aos pais na Feira Cultural do Colégio Nascimento.

Fizemos um convite grande para ser colocado na entrada da escola ao lado do convite de outras classes que apresentarão atividades diversas no dia da Feira. Cada criança assinou seu nome e desenhou algo de sua preferência. Comentamos sobre os valores humanos e Ivã disse que antigamente não havia envelope... os convites eram entregues enroladinhos, fazendo menção ao formato do desenho que fiz em uma cartolina parecido com uma folha enrolada nas pontas (idéia de um pergaminho). 


\section{Comentários}

Percebi que nesta sessão e na anterior o valor humano AMIZADE foi muito bem aceito pelas crianças. A classe apresenta atitudes típicas da idade como competir com a atenção do adulto, ficar de mal, dar o dedinho para ficar de bem, disputar objetos etc...Parece que com as histórias contadas sobre "amigos" o grupo sentiu a necessidade de dividir mais seus pertences, embora ainda sintam dificuldades neste aspecto. Quando desejam algo recorrem a mim dizendo mais ou menos o que diz Alana: "- Tia Selma, eu preciso da caneta da Gabriela,,, Já pedi "por favor" e mesmo assim ela não quer me emprestar..." Temos conversado bastante a respeito da importância de dividir e compartilhar, ajudando os colegas; no entanto, este ponto ainda continua sendo um grande desafio a ser vencido

\section{Décimo nono dia - 24/9/98 Objetivo}

Aprofundar o valor da AMIZADE, enfocando o AMOR entre as pessoas.

Histórias infantis: Amor de ganso e Pela porta do coração

Valor humano: AMOR

\section{Descrição}

Cheguei à sala e as crianças disseram bem alto "boa tarde". Karen e Vitor tamparam os ouvidos. Cumprimentei-os e, em seguida, subimos para o salão. Cantamos a música de entrada e as crianças queriam saber qual seria a nova história

Sentamos em semicírculo, pois tenho percebido que as crianças disputam entre si para se sentarem ao meu lado para ver, antes dos colegas, o que acontece quando viro as folhas dos livros de histórias.

Minha intenção é justamente aproximar o grupo e não destacar a atenção para alguns; por isso, juntando este fato a uma estratégia que aprendi, em um curso que comecei a fazer sobre contadores de histórias, decidi tentar colocar em prática o que me foi aconselhado no referido curso: é aconselhável que o contador fique em uma posição central estratégica e que os ouvintes coloquem-se em meia lua à sua frente.

Nas duas últimas sessões, coloquei esta sugestão em prática e parece que as crianças estão menos ansiosas, agora, para disputar o lugar ao meu lado.

Expliquei-lhes que, naquele dia, precisaria da ajuda delas para contar a história porque não havia letras, só desenhos, no livro escolhido.

Mostrei a capa às crianças; Ivã leu o título da história e também o nome da autora.

Alana entusiasmou-se para contar a história e não queria parar de falar. Pedi para dar a vez aos colegas, o que fazia com grande dificuldade.

As crianças acharam, inicialmente, que o ganso queria ser amigo da galinha. Depois começaram a falar em namoro. Alana criou frases para a história 
usando, inclusive, o discurso indireto: "...Então eles disseram: - Como vocé vai namorar com uma galinha?" Disse que a história parecia com aquele programa do Silvio Santos: "-É namoro ou amizade?" Todas se divertiram com a situação..

O grupo ficou sensibilizado quando o ganso protegeu a galinha e os pintinhos da chuva, com suas grandes asas, enquanto os outros gansos ficaram dentro da casa

Ivã afirmou que o ganso chorou porque ficou emocionado ao receber uma flor do pintinho

Conversamos bastante sobre a importância de se gostar das pessoas como elas são. Para as crianças, a proximidade entre a galinha e o ganso pareceu natural e torciam para que desse tudo certo entre eles.

Ao final da história, Cristiane, como sempre, completou: " $-E$ eles viveram felizes para sempre".

Luana havia visto outro livro sob minha pasta e comentou se eu não iria contar outra história. Expliquei ao grupo que seriam eles os contadores da história.

Dessa vez, o interesse das crianças parece ter aumentado, pois não conheciam a história. Acharam interessante o formato da casa como um coração.

Observaram os detalhes como: um olho na janela, o menino andando de skate, a mão pegando as flores, o quadro etc

Ivã disse que o coração deixou o menino entrar porque ele havia levado muitos presentes. Comentava: "- O que será que vai acontecer agora?" Perguntei às crianças se era só pelos presentes ou seria porque o coração gostava do menino. As crianças optaram pela segunda alternativa.

As crianças comentaram que o menino e o coração estavam tristes porque ficaram separados. Adivinharam que a carta que o menino recebera era do coração e disseram que o menino devia gostar muito do amigo porque afinal "ele foi lá no céu pegar uma estrela para lhe dar de presente." Ficaram admiradas com o brilho final da casa do coração que ficou cheia de estrelinhas porque os amigos nunca mais se separaram

Depois de comentarmos sobre a amizade e o amor às pessoas, voltamos à sala de atividades. Propus às crianças que escolhessem a história que gostaram mais e fizessem um desenho sobre ela.

Inicialmente, a maioria das crianças escolheu "Pela porta do coração"; algumas disseram que iam fazer dois desenhos $e$, no final, quase todos acabaram fazendo desenhos sobre as duas histórias (Amor de ganso e Pela porta do coração), com bastante interesse.

\section{Comentários}

Embora as crianças tenham demonstrado interesse em formular com suas próprias palavras as histórias a partir dos desenhos, ainda sentem dificuldade quanto a esperar sua vez de falar. Alguns parecem achar mais fácil apenas escutar. No entanto, considerei um exercício criativo para o grupo que acabou superando minhas expectativas quanto aos detalhes observados nas cenas das histórias e, também, em sua capacidade de inventar narrativas inusitadas para as diferentes 
situações propostas, sempre tentando aproximar os personagens a um desfecho feliz. Alana, Ivã, Karen, Luana e Letícia, particularmente, destacaram-se no grupo nesse sentido

\section{Vigésimo dia - 28/9/98 \\ Objetivo}

Dar oportunidade a todos de relembrar as histórias apresentadas durante o projeto, assim como contemplar os alunos que, por algum motivo, faltaram. Para tal, pretendia utilizar o monitoramento dos alunos que estavam presentes durante a apresentação das histórias, contando-as para os colegas.

\section{Descrição}

Quando cheguei à sala de atividades, as crianças estavam olhando alguns livros de histórias que ficam guardados na "sapateira" plástica da classe.

Cumprimentei-as e elas logo perguntaram se contaria história nova. Expliquei que iriamos relembrar algumas histórias e que os colegas que lembrassem contariam para aqueles que faltaram nos dias de apresentação das histórias.

Em seguida, coloquei os livros de todas as histórias em um suporte sobre a lousa e as crianças foram falando o nome das histórias espontaneamente, antes mesmo que eu perguntasse algo.

Murilo. Eduardo, Letícia, Jessica e Ivã logo manifestaram-se dizendo que tinham faltado e não conheciam algumas histórias. Pedi à classe para que contassem aos colegas. Solicitei às criança que cada uma tivesse a sua vez de falar, sem atrapalhar os colegas.

O grupo correspondeu ao meu pedido, com exceção de Alana que se esforça mas não consegue, ainda, esperar sua vez de falar (embora tenha apresentado maior controle nas últimas sessões).

Após o comentário sobre as histórias, expliquei à classe que participariamos da Feira Cultural da escola e que precisaria da ajuda de algumas crianças para demonstrar nossas atividades. As crianças entusiasmaram-se e quiseram saber onde ficariam. Como a professora da classe irá usar a sala de atividades para expor trabalhos das crianças sobre animais nocivos, disse-lhes que ficariamos na biblioteca (sala ao lado) e que a nossa exposição seria sobre histórias infantis.

Pedi às criança que levassem para casa a segunda parte das questōes sobre as histórias lidas em classe, para saber quem lembrava das histórias que eu havia contado. Disse-Ihes que deveriam contar o que lembrassem para os pais ou adultos responsáveis por elas. Thalita quis saber por que eu não tinha mandado a cartinha pelo correio. Expliquei que era por causa da proximidade da Feira Cultural e que eu precisava da resposta logo.

As crianças fizeram o desenho da esquilinha caprichosa e relembraram a história, dizendo que tinha sido a primeira história contada. Confeccionaram o espanador da esquilinha para a exposição, pois o outro exemplar haviam levado para casa há algum tempo atrás, por pedido das próprias crianças. Algumas pediram-me para escrever trechos da história, segundo o desenho que haviam feito. 


\section{Comentários}

Fazendo o retrospecto das histórias, percebi que as crianças são realmente capazes de guardar detalhes sobre as narrativas apresentadas, principalmente, daquelas que lhes despertam maior interesse ou afinidade. O tempo é fator primordial para esse trabalho porque todas as crianças querem falar, expondo suas idéias. É importante considerar as colocações de todo o grupo. Isso parece dar-lhes uma grande satisfação, consideração e contentamento perante os colegas.

\section{Vigésimo primeiro dia - 29/9/98 \\ Objetivo}

Esclarecer às crianças sobre a finalidade da exposição das atividades que desenvolveram a partir das histórias apresentadas.

\section{Descrição}

Quando cheguei à escola, fui para a sala e notei que as crianças estavam muito agitadas com as atividades desenvolvidas sobre o tema da classe para a Feira Cultural: animais nocivos.

Cumprimentei-as e muitas continuaram falando bastante alto. Expliquei que precisaria que lembrassem o nome das histórias para que pudessem me ajudar na exposição de sábado e simultaneamente fui tirando todos os livros de histórias que já havia contado para a classe. Aos poucos, foram acalmando-se e prestando mais atenção em minha fala.

Pedi a elas que me ajudassem a lembrar o nome das histórias em que cantamos algumas músicas. Cantavam e faziam gestos conforme olhavam a seqüência das histórias que havia colocado em exposição sobre um suportẹ na lousa da classe

A seguir, as crianças escolheram os livros que "gostariam de ler". As não alfabetizadas, solicitaram "olhar os desenhos", como costumam dizer. Começaram a manusear com grande interesse todos os livros, afinal, agora já conheciam todas as histórias

Alana queria "contar as histórias para todos os colegas." Victoria pediu.para "ler para a classe." Murilo explicou que "não sabia ler, mas que queria ver o livro dos porquinhos." As crianças trocaram os livros espontaneamente entre elas, assim que terminaram de olhar. (Fotos 17 e 18- Anexo: p. 221).

Tive que interromper várias vezes a fala das mais ansiosas (Alana, Luana, luri, Letícia, Eduardo etc), pedindo para dar a vez a todos os colegas se expressarem um pouco, dentro do que queriam ressaltar sobre as histórias que olharam.

Foi muito interessante esta reação do grupo pela coletânea de históriass. Eduardo e luri encantaram-se com o Livro das Virtudes. Eduardo veio mostrar-me um desenho muito bonito na página 99, apontando a figura de um anjo com muitas estrelas sobre um menino dormindo profundamente. Seus olhos brilharam ao me mostrar esta cena. 
Algumas crianças ficaram manuseando os livros até o final das atividades. Alana, por último, pediu para olhar mais uma vez o Livro das Virtudes, antes de ir embora. Depois quis ajudar-me a guardar o livro em minha pasta.

\section{Comentários}

$\mathrm{Na}$ verdade, a sessão que seria mais uma orientação às crianças sobre a Feira Cultural de 03/10/98 precisou ser um pouco alterada devido à grande agitação das crianças. Aliás, naquela semana não se falava em outra coisa na escola; por isso, resolvi adequar as atividades programadas ao interesse das crianças, mas com o cuidado de respeitar este grande tema, até então inusitado para elas. O grupo parecia sentir-se muito importante pela oportunidade de apresentar um trabalho desenvolvido na classe e que seria apresentado aos visitantes da Feira Cultural pelas próprias crianças. Elas explicariam, demonstrariam e participariam ativamente do evento aberto à comunidade. Percebi, nitidamente, neste dia, que a música foi de grande auxílio para que o grupo voltasse, aos poucos, a se acalmar. Confirmei, mais uma vez a necessidade de respeitar o momento da criança e o seu próprio tempo para nossas colocações de adultos. Se realmente as respeitamos e aguardamos, com certeza elas acabam nos ouvindo. Nesta sessão, isso ficou, mais uma vez, bastante claro para mim. Algumas crianças foram escolhidas de acordo com a preferència das mesmas para a apresentação sobre animais nocivos e outras preferiram ficar na biblioteca para apresentar aos visitantes as histórias infantis e as atividades que desenvolveram sobre este tema.

\section{Vigésimo segundo dia - 2/10/98 \\ Objetivo}

Organizar as atividades elaboradas pelas crianças, nos espaços que já haviamos, previamente, estabelecido

\section{Descrição}

Quando cheguei à escola, as professoras, os alunos do Ensino Fundamental e os demais funcionários já estavam trabalhando nos diferentes stands da Feira Cultural

A diretora informou-me que o espaço a ser utilizado pelo Pré A já havia sido forrado por uma funcionária da escola, adiantando o serviço de preparação inicial do ambiente. Pediu para que eu verificasse se estava de acordo com a proposta de trabalho da classe. Agradeci a ajuda e dirigi-me à sala de exposição.

As prateleiras da sala onde são guardados os livros já haviam sido, entāo, forradas com papel branco, como fundo, e algumas atividades das crianças, tais como desenhos e cartazes, foram afixadas sobre o mesmo, sendo organizadas e identificadas, segundo o titulo de cada história infantil e o valor humano a ela correspondente, conforme havia combinado com as crianças, anteriormente. No beiral da janela, os livros foram colocados, um ao lado do outro, e, sobre algumas carteiras, foram agrupadas as demais atividades das crianças, tais como as peças montadas com massa de modelar e os livros elaborados pelas próprias crianças.

Solicitei, ainda, o vídeo e o som para demonstrar algumas passagens das crianças durante as sessões de estágio, mas devido à grande procura, naquele 
momento, destes recursos por muitas classes, simultaneamente, a diretora não me deu certeza sobre o atendimento ao meu pedido.

\section{Comentários}

Percebi grande envolvimento de todos trabalhando na preparação da Feira Cultural. Embora a professora do Pré A tivesse me explicado que as crianças não viriam neste dia devido ao cansaço do dia anterior e até mesmo da semana inteira na organização do evento, senti falta das mesmas, pois sempre que estávamos juntas faziam muitas perguntas, conversavam e favoreciam uma aprendizagem coletiva prazerosa. dinâmica e significativa. Por sorte, já haviamos combinado como seria a organização de nosso stand, e que no sábado chegariamos um pouco antes do inicio do evento para conversarmos e trocarmos, ainda, algumas idéias sobre o espaço, caso tivessem mais alguma sugestão a fazer sobre a disposição de suas atividades

\section{Vigésimo terceiro dia - 3/10/98}

Objetivo

Avaliar o comportamento das crianças perante os visitantes da feira, ao exporem o que tivesse ficado de mais significativo das histórias apresentadas, no que se refere aos valores humanos.

\section{Descrição}

As crianças responsáveis pela exposição dos trabalhos foram: Ivã e Victoria, em um primeiro momento, das $13 \mathrm{~h} 30$ às $15 \mathrm{~h} 30$, e Nathan e Thalita, em um segundo momento, das $15 \mathrm{~h} 30$ às $17 \mathrm{~h} 30$. As demais revezaram-se para atender aos visitantes do stand, montado na sala do Pré $A$, sobre os animais nocivos.

A medida que os visitantes entravam na sala de exposição, as crianças mostravam os livros das histórias apresentadas e as respectivas atividądes produzidas a partir das mesmas.

A principio, ficaram meio constrangidas e envergonhadas, mas, aos poucos, foram contando as histórias, com prazer e, para os familiares ou pessoas mais próximas, cantavam algumas canções pertinentes às histórias e exemplificavam as atividades desenvolvidas, mostrando as fotos que estavam afixadas em dois painéis de isqpor

Nathan pediu para sentar e reler os livros em exposição (Foto 19- Anexo: p. 221). Seus pais pediram para que eu escrevesse a letra das canções cantadas na classe, pois, segundo eles, Nathan constantemente comentava as histórias e elogiava as músicas que as acompanhavam. Eles solicitaram, ainda, a continuidade do projeto, comentando que o filho estava muito interessado neste trabalho. Recordaram as histórias de sua própria infância, que eram ouvidas, também, em pequenos discos coloridos como, por exemplo: O lobo e o cordeiro, A formiga e a neve, $O$ boneco de açafrão.

Outros pais também vieram elogiar o trabalho, pedindo continuidade para as séries seguintes, mostrando-se satisfeitos ao ouvir as crianças e observar as atividades. 
A supervisora da escola pediu explicações e detalhes sobre o projeta e considerou importante as atividades relativas à vivência dos valores humanos pelas crianças.

As crianças que visitaram a exposição pareciam muito curiosas (Foto 20- Anexo: p. 221). Pediram explicações aos expositores e mostraram-se muito satisfeitas ao receberem um livro-lembrança, ao saírem. Esta lembrança representava um incentivo à leitura e foi conseguida por doaçāo de algumas editoras para a escola, propiciando mais uma oportunidade de contato com os livros e a possibilidade de reflexão sobre os valores humanos do projeto em questão.

\section{Comentários}

Embora as crianças tenham se mostrado um pouco cansadas após a exposição. percebi que estavam bastante orgulhosas ao apresentarem os trabalhos da classe. especialmente ao contarem sobre as histórias, mostrando as fotos e comentando seus pontos de vista aos visitantes.

$\dot{E}$ interessante observar como os visitantes e familiares, em geral, consideram importante o trabalho com valores humanos nas histórias infantis, contando sobre a repercussão destas atividades sobre as crianças, detectadas nos comentários e comportamento das mesmas em casa.

\section{Vigésimo quarto dia - 6/10/98 \\ Objetivo}

Observar o significado de o que é ser amigo para as crianças, pois, conforme dicas e pistas que elas me ofereciam, percebi que precisava aprofundar a dsicussāo sobre o valor AMIZADE.

\section{Descrição}

Após ter trabalhado com os valores humanos propostos para o projeto, por intermédio das histórias infantis, senti a necessidade de retomar o valor "amizade" pela grande demonstração de interesse das crianças em relação ao livro "Amigos". Essa idéia havia sido discutida durante a supervisão de estágio, o que muito contribuiu para o amadurecimento e ampliação da proposta inicial do trabalho em questão.

Quando cheguei à sala, as crianças, como sempre, pediram para que eu contasse mais uma história.

Perguntei-Ihes sobre o que tinham achado da Feira Cultural e elas foram unânimes em afirmar que tinham gostado muito e algumas pediram-me o livrolembrança que foi distribuido aos visitantes da exposição (por doação de editoras), pois no dia do evento não haviam pego no stand da biblioteca. Comprometi-me com as crianças, garantindo que cada uma ganharia um livro de história como lembrança de nossa participação na Feira Cultural e todas ficaram entusiasmadas com a informação.

Percebi que havia uma criança nova na classe. Apresentei-me e perguñtei seu nome. A diretora já havia comentado que chegara há pouco tempo da Venezuela e que apresentava dificuldade para falar Português. Disse-me que se 
chamava Nathan. Notei que apresentava, também, alguma dificuldade de dicção. Demonstrava não seguir os combinados da classe, parecendo ignorar a fala da professora

Aproveitei a oportunidade para discutir com as crianças a chegada de um novo amigo à classe, já que algumas mostravam-se completamente indignadas com a falta de adaptação do recém-chegado à escola.

Comentei com elas que havia trazido uma nova música para cantarmos juntas: "Boa tarde, amigo". Ficaram bastante entusiasmadas, pois adoram cantar. $E$ assim o fizemos

\author{
Boa tarde, amigo \\ Boa tarde, irmão \\ Paz no sorriso \\ E cante uma canção \\ As flores no campo \\ As nuvens no céu \\ As águas no rio \\ E um barco de papel \\ Venha comigo \\ Estenda a sua mão \\ Enfrente a maré \\ Cantando esta canção
}

Expliquei às crianças que, ao invés de eu contar histórias, eles é que contariam "coisas" para mim naquele dia. Mostrei o livro "Amigos" e perguntei se lembravam da história, aproveitando a ocasião para inteirar Nathan Marinho, o colega recém-chegado, sobre os acontecimentos da narrativa. Todos responderam de forma afirmativa e já foram explicando os fatos ocorridos.

A seguir, pedi, então, para que me contassem o que era ser amigo. As crianças pediram para que eu escrevesse na lousa "amigo para sempre", antes de começarem a dar suas opiniões.

A lista que escrevi na lousa, conforme o depoimento das crianças, ficou assim estabelecida:

\title{
O QUE É SER AMIGO... AMIGO PARA SEMPRE...
}

Karen: ficar conversando

Thalita: ficar ajudando.

Ivã: ficar sempre junto.

Jéssica: brincar e não brigar.

Alana: emprestar coisas e dormir na casa do outro, falar por favor, brincar de boneca, de casinha e de carrinho.

Júlio: brincar junto. 
Luana: nunca brigar, brincar com o amigo.

Victoria: dar presente para Luciana, minha prima.

Vitor: catar coisas que caiu no chão, ajudar e ser amigo para sempre.

lury: não bater nos coleguinhas.

Cristiane: não ser que nem a minha irmã que me despreza, amigo legal tem que gostar da gente.

Murilo: não brigar.

Nathan Marinho: brincar junto sem bater, nem brigar. O Junior é amigo.

Depois do comentário das crianças, propus que fizessem desenhos sobre o que tinhamos conversado e escrito na lousa.

As crianças desenharam e pintaram cenas diversas e em sua maioria referentes a ambientes fora da escola onde costumavam brincar com seus amigos, como a casa delas, o quintal da casa dos avós, a casa dos primos etc. Algumas histórias que as crianças me contaram sobre os seus desenhos foram as seguintes:

Luana: A casa de todos os amigos... Eles ajuntam e vão brincar de boneca. (Figura 13- Anexo: p. 214).

Júlio: Eduardo, meu amigo...Meu primo Guilherme... Eles estão brincando no quintal e na praia. Eles estão dentro do coração (Figura 14- Anexo: p. 214).

Nathan : É o meu amigo Junior.

Thalita: Aqui é eu carregando meu amigo, Leonardo. Ele foi na minha cașa. Eu carreguei ele no carrinho, quer dizer, na bicicleta... Esqueci que não tenho carrinho nenhum.

Karen: Essa é a casa da minha avó. Essa sou eu. Eu estava saindo da casa da minha avó. Esse é o Maciel, meu tio. Ele é irmão da minha mãe. O carro do meu tio. O meu pai emprestou o guarda-chuva para o meu tio. O meu pai empresta as coisas. Eu estava saindo com guarda-chuva amarelo. Todos são amigos.

Jéssica: Eu e minha amiga Vanessa brincando.

Alana: A tia Viviane ajudou a tia Selma se salvar da tempestade. As duas moravam juntas e ficaram amigas para sempre.

lury: Aqui é minha casa...Meu prédio... Aqui é meu amigo, Eduardo, que pulou do prédio com capa. Aqui quando era mais pequeno, com só 4 anos. Aqui é meu pai, é Toninho. Esqueci de fazer minha mãe, Arlene. O filhotinho da Xuxinha, Branco. Tem 3 aninhos. Aqui é meu cachorrinho, Branco e a Xuxinha.

Vitor: Eu, Vitor. Meu amigo (Karen)...Flores.

Murilo: Meu amigo, Vinicius.

Ivã: Júlio e Nathan brincando. Vitor...Meu irmão e lury (de mãos dadas), Thalita e Luana dormindo. Eu. Minha irmã.

Cristiane: Essa sou eu. Minha irmã Juliana (dois coraçōes). Aqui sou eu e meu irmão. Eu gosto do meu irmão quando ele faz palhaçada. Eu quero falar que eu amo minha irmã e meu irmão, Tiago. 


\section{Comentários}

Percebi, mais uma vez, o quanto é importante para as crianças ter amigos. Para muitas, os amigos de verdade são todos aqueles que têm uma relação direta com o coração (aqueles que estão dentro do coração); para outras, os amigos são as pessoas da familia. Algumas crianças chegam a relacionar animais em sua lista de amigos. O que parece ser fundamental para as crianças é ter alguém para dividir tudo: as alegrias e as tristezas e, mesmo apesar de algumas queixas, os amigos sāo aqueles que ficam sempre juntos: "amigos para sempre". Fiquei surpresa ao perceber que a maioria das crianças desenhou ambientes externos à escola para demonstrar situações de convivio com seus amigos. Por que será? Talvez considerem o espaço da escola muito formal para estreitar os laços de amizade, ou, quem sabe, considerem a amizade algo muito sério para ser tratado no curto periodo de tempo que passam na escola? Apesar de minhas indagações, não consegui chegar, ainda, a uma resposta convincente. Inquietei-me bastante com essa observação e levei-a para discutir na próxima sessão de supervisão. $O$ desenho de Nathan Marinho, aluno recém-chegado chamou-me, particularmente, a atenção. Senti uma certa solidão em sua história, pois, na verdade, no momento em que estava vivendo na nova classe e no novo pais, demonstrou ter só um amigo: Junior, que na verdade é seu irmão (os pais são separados. Ele e o irmão vieram para o Brasil para ficarem com uma tia). Percebi a necessidade de ajudar Nathan a se integrar o mais rápido possivel ao grupo. Talvez o trabalho com o valor humano "Amizade" possa ajudá-lo, um pouco mais, nesse sentido. Este será um novo desafio para as próximas sessões.

\section{Vigésimo quinto dia - 14/10/98 Objetivo}

Descobrir, junto às crianças, como era, para elas, brincar de amigo. Este objetivo reforçava o novo desafio de descobrir os valores próprios das crianças, a partir do relato sobre suas histórias e concepções, o que já havia começado a fazer na sessăo anterıor discutindo a AMIZADE.

\section{Descrição}

Cheguei à classe e as crianças estavam lendo livros de histórias. Cumprimentei-as e, logo em seguida, pediram-me para contar uma nova história.

Expliquei às crianças que eu já havia contado algumas histórias para elas e que agora gostaria que elas contassem outras histórias para mim.

Primeiramente, retomei algumas questões sobre a amizade e perguntei a elas como brincavam de amigo. As respostas foram variadas e envolviam diversos tipos de brincadeiras. Simultaneamente à nossa conversa, as crianças iam recolocando as afirmações sobre os amigos, comentadas na lista da sessão anterior, à medida que davam suas opiniões.

Os vários tipos de brincadeiras sugeridos para brincar de amigo foram:

- dominó

- pega-pega

- Barbie 
- esconde-esconde

- bonequinho

- carta

- dama

- boneca com a amiga

- escolinha

- jogo da memória

- posto de Gugu

- carrinho

- panelinha e cachorrinho

- contar história e prestar atenção

- roda-roda

- bicicleta

- boneco

- amarelinha

A seguir, sugeri às crianças que brincassem de amigo e que fossem contando-me as histórias de suas brincadeiras. Assim, as crianças, em grande maioria, dividiram-se em grupos, espontaneamente, e utilizaram jogos de encaixe para brincar de amigo, em diversas situações como mencionarei abaixo.

Cristiane (sozinha): Estou brincando de boneca. Elas são amigas porque estão brincando juntas

Karen, Jéssica, Thalita, Vitor: "ESCOLINHA". Estamos brincando de escolinha. Tem que ser de par em par por isso a Cristiane não pode brincar com a gente. O ônibus da escola veio de longe cheio de amigos. Eles falaram que eram amigos e a professora falou: - ele gostou de ti (apontando para mim)... Um fez xixi na cabeça do outro, mas era de brincadeira (Karen). Pediu desculpa e colocou ele no varal para secar (Vitor)

Victoria, Eduardo, Júlio, Nathan Rodrigues: "ESPAÇONAVE". Essa ė a espaçonave onde vão todos os amigos. Os ursinhos carinhosos caminham no céu, assistem TV juntos, um é bonzinho para o outro. Quando um está em perigo, o outro ajuda. Eles são seis, vinte ou cinco. Só tem um que é malvadinho... faz coisa ruim. Primeiro os ursinhos batem nele e depois ele bate. O medroso tem medo de altura. O meu está assistindo Tom e Jerry. Tem os carros de nuvem e as chaves de nuyem.

Ivã, Luana, Alana: "DÁLMATAS E A COMIDINHA". Os Dálmatas e a comidinha são amigos porque eles ficam todos juntos. Brincam de morder sapato, futebol, bola. A comidinha que a tia e o tio fazem pra os cachorrinhos (mostram com as peças do jogo de encaixe).

lury, Nathan Marinho, Murilo: "BONEQUINHOS". São amigos. Um do mal, Superman e uma aranha de seis braços era amiga do Hulk. Tem uma perninha 
acompanhante que ajuda eles. - Amigo, você ia cair e eu vou ajudar...-Calma ai, eu já vou (lury).

\section{Comentários}

Nesta sessão, senti que, apesar de as crianças apresentarem diferentes tipos de brincadeira, o que importa realmente é estar junto dos amigos, nos bons e nos maus momentos, dividindo as emoções e compartilhando os sentimentos. O fazde-conta demonstra bastante esta necessidade de ficar junto, ou, ainda, possibilita o exercicio dessa AMIZADE, cujos componentes abrangem aspectos como ajudar e até mesmo brigar, mas depois perdoar e continuar amigo.

\section{Vigésimo sexto dia - 28/10/98 \\ Objetivo}

Compreender qual era o significado de ser amigo, para as crianças, em outro espaço diferente da classe, mas dentro da escola, pois quanto ao primeiro espaço, já haviam relatado as situações de AMIZADE: ajudar, emprestar e organizar - material etc. Essa idéia nasceu a partir dos desenhos feitos, anteriormente, quando as crianças desenharam seus amigos em ambientes e situações fora do espaço da escola. Minha intenção era descobrir como ficava o valor AMIZADE, para elas. dentro dos diversos ambientes escolares. Haveria ou não alguma diferença neste sentido? Para esclarecer um pouco mais essa questão, inicialmente, escolhi o refeitório

História infantil: O livro do dragão:

Valor humano: AMIZADE

\section{Descrição}

Cheguei à sala e cumprimentei as crianças. Elas receberam-me com entusiasmo habitual e pediram mais histórias

Expliquei que precisaria, ainda, da ajuda delas para me contar mais algumas histórias, mas que depois contaria uma nova.

Começamos retomando a conversa sobre AMIZADE. Pedi para que falassem sobre os amigos do lanche: "- Os amigos do lanche são os mesmos que vocês têm na classe? Quem são esses amigos? Por que vocês acham isso?" Discutimos bastante essa questão e elas demonstraram que, embora o tipo de ajuda dado na classe, pelos amigos, fosse diferente daquele do refeitório, o amigo que ajudava na classe era o mesmo que ajudava no lanche.

A seguir, as crianças foram para o refeitório tomar lanche e combinamos que me contariam sobre as histórias dos amigos do lanche quando retornássemos à sala (Fotos 21 e 22- Anexo: p. 222).

Ao retornar do lanche, as respostas das crianças foram variadas como relatarei a seguir

\section{AMIGOS DO LANCHE:}

Jéssica: Gabriela, Victoria, Leticia. Elas são legais.

Luana: Gabriela, Victoria. Deu bolacha e salgadinho. 
Cristiane: Leticia (deu bolacha) e Gabriela.

Murilo: Jéssica (abriu minha lata de guaraná)

Karen: Vitor, Ivã, Eduardo, Júlio (comprou salgadinho, deu salgadinho, jogou papel no lixo para mim)

Vitor: Karen, Ivã, Alana, Eduardo, Nathan Rodrigues (tentou abrir a lata de refrigerante, pediu um pedaço de bala, deixou sentar no lugar).

Ivã: Karen, Vitor, Eduardo, Alana, Nathan Rodrigues (conversamos juntos).

Nathan Marinho: Alana, tia Viviane, Cristiane (deu lanche).

Alana: Nathan Marinho, Cristiane, Leticia, Vitor, Karen, Eduardo, Victoria, Gabriela (deixou brincar)

Leticia: Cristiane, Karen, Gabriela, Victoria, Alana, Luana, Jéssica (conversamos juntas)

Jülio: Karen, Eduardo, Nathan Rodrigues, Vitor, Ivã (comprei seis pirulitos porque gosto deles)

Victoria: Gabriela, Eduardo, Alana, Leticia, Jéssica, Karen, Vitor (andaram junto comigo)

Gabriela: Victoria, Leticia (ficaram perto de $\mathrm{mim}$ )

Nathan Rodrigues: Eduardo, Júlio (conversei com eles).

Eduardo: Nathan Rodrigues, Júlio, Victoria (eles conversaram comigo que a tia Selma estava invisivel). lanche)

Thalita: lury (conversamos sobre nossas lancheiras e o que trouxemos de

Depois de conversarmos sobre os amigos do lanche, apresentei às crianças, como havia prometido. uma nova história: "O livro do dragão", retomando a questão do ser amigo e buscando encontrar novas respostas das crianças sobre AMIZADE

Elas demonstraram bastante interesse pela história e fizeram desenhos contando fatos criados a partir da narrativa apresentada. Os relatos apresentados por elas, a partir dos desenhos, seguem abaixo.

\section{LIVRO DO DRAGÃO}

Karen: O dragão e o ratinho estavam conversando e o sol estava olhando porque ele queria ver por que eles eram amigos. Apareceu o diabo com cara de indio e falou para eles não serem amigos. Mas o coelhinho apareceu e disse para eles serem amigos. E o dragão e o ratinho obedeceram a nuvem que falou que o papai do céu pediu para eles serem sempre amigos do bem. E eles ficaram amigos para sempre.

Luana: O ratinho estava em cima do dragão. Eles iam para o zôo ver os bichos: o macaco, a girafa, o leão, a vaquinha. Eles se encontraram no meio do caminho. O ratinho achou o dragão grande e bonito. O dragão falou: - Você é muito pequenininho. Eles se gostaram e ficaram amigos para sempre e acabou... 
Thalita: Só o dragão passeando. Esqueci de desenhar o ratinho, mas ele é amigo do dragão. O dragão parou para comer e no meio da estrada encontrou o rato, só que aqui eu não fiz.

Júlio: O porquinho do zôo era amigo do dragão e do ratinho. Eles vão para o zôo brincar de bola. O porquinho e o galinho pensavam que o dragão era mau e descobriram que ele era do bem.

Eduardo: O dragão e o ratinho estavam andando para casa para brincar juntos de pega-pega. Eles se gostavam e não brigavam. Ficavam juntos para sempre e todo o dia eles passeavam

Murilo: O dragão estava tentando arrumar amigos. Ele conseguiu o ratinho. Os outros também eram amigos e moravam no zôo. Ficaram amigos para sempre.

Alana: O dragão e o rato iam para o zôo. Os animais eram vários. Tinha quarenta mil, setecentos e quarenta animais e quinhentos também, por isso não deu para desenhar tudo. Senão, vou fazer fora. - Por que não entramos no zôo? - falou o ratinho. Queriam arrumar amigos e fazer amizade e ganhar o som com pilha e viver felizes para sempre. E viveram porque ganharam todos os amigos.

Ivã: O dragão estava fazendo aniversário. Fazia 31 anos. Havia uma festa. Tinha o jacaré, a esquila, o lobo de gravata, o elefante e o porco-espinho, comendo sanduiche

O ratinho estava falando: - Feliz aniversário, meu bom amigo. O dragão ganhou um carro bem grandão. O pai dele ensinou ele a dirigir. Ele falou: - Eu sou o dragão! Todos eram amigos e agora tinha acabado a história.

Cristiane: O dragão e o ratinho iam para o zôo ver quem ia ganhar o radinho. O dragão ganhou o radinho e o amigo. Foi mais legal ele ganhar o amigo. Ele era muito sozinho e eles ficaram amigos para sempre. As caretas são enfeites do desenho. Gostei bastante da história (Figura 15- Anexo: p. 215).

Victoria: $O$ dragão e o ratinho estavam passeando para ir para casa. $O$ dragão arrancou cinco florzinhas para pôr no vasinho. Eles ficaram amigos para sempre porque o ratinho ia sempre dormir na casa do dragão. Gostei muito dessa história.

Nathan Rodrigues: Eles estavam felizes porque o dragão ganhou o rádio. Continuaram amigos. Foram para casa, tomaram banho e dormiram. E acabou a história.

Leticia: O ratinho e dragãozinho estavam passeando pelo mato. Eles viviam juntos para sempre. Estavam sempre perto: brincavam, dormiam e ficavam juntos para sempre. Gostei da história.

Gabriela: Eles estavam andando no mato. Eles estavam pegando flores para colocar no vasinho do rato. Os dois gostavam de flores. Depois eles chegaram em casa e foram ver os passarinhos. Eles eram amigos porque se gostavam muito.

lury: O papagaio foi buscar comida. E o cachorro está atrás. O dragão e $O$ ratinho carregaram um queijo bem grandão. O papai, a mamãe e o filhinho foram passear no zôo, mas não viram o papagaio porque ele voou antes. Tinha uma florzinha pendurada que era filhote. $E$ todos eram amigos. 
Vitor: Era Carnaval. Estavam nascendo as florzinhas. O dragão gostava de flores e deu de presente às florzinhas. O ratinho só comia queijo. O dragão comprava queijo para o ratinho porque eles eram amigos e se gostavam. O dragão também comprava macarrão, nhoque, lasanha. $E$ as flores davam frutinhas para eles e para as outras flores também. E a nuvem deixou aparecer o sol bem bonito. $E$ as florzinhas pegaram o guarda-chuva para não pegar muito sol para não ficarem doentes (Figura 16- Anexo: p. 215)

Nathan Marinho: É o dragão e o Mickey. Ele está passeando par casa. Ele ia comer. Ele tem muitos amigos. Eu tenho só dois. Gostei da história.

Jéssica: O dragão estava levando o ratinho para o zoológico porque o ratinho era amigo dele. Ele conversaram, se gostaram e ficaram amigos para sempre.

\section{Comentários}

A conclusão das crianças sobre os acontecimentos deste dia foi muito significativa: "- Amigo não é só quem dá coisas... É quem é legal: não bate, não briga, fica junto e vai dormir na nossa casa... O dragão da história ficou feliz porque era sozinho e ganhou amigos, além do radinho de pilha de presente do zoológico".

Neste dia, observei que diferentes ambientes podem suscitar respostas mais especificas sobre o ser amigo; no entanto, a essência da amizade permanece e a resposta constante em todas as situações, até agora comentadas pelas crianças, refere-se à ajuda mútua, ao estar junto, mesmo sem nada dizer, é simplesmente estar perto. Para as crianças ficar só parece ser algo muito penoso e sofrido como era para o dragão até encontrar o melhor de todos os presentes, que foi o seu amigo ratinho, pois apesar de todas as diferenças e divergências, os amigos acabam ficando juntos para sempre. Esta grande lição aprendi nesta sessão com as crianças

\section{Vigésimo sétimo dia - 3/11/98 Objetivo}

Dar continuidade à idéia do encontro anterior, buscando respostas das crianças sobre o que é ser amigo em diferentes situaçöes e ambientes. O local escolhido para esta sessão foi o parque

\section{Descrição}

Ao chegar à sala, cumprimentei as crianças e pedi que me ajudassem, continuando a contar suas histórias sobre ser amigo.

A seguir, perguntei a elas se gostavam de brincar no parque. Todas foram unânimes em afirmarem que sim. Disseram-me que havia muitos brinquedos no parque e que "era melhor brincar com os amigos do que sozinho porque os colegas ajudam e, também, porque na gangorra não dá pra brincar sozinho. É mais legal brincar junto."

Os brinquedos que mencionaram haver no parque foram:

- piscinas de bolinhas (1)

- casinhas (2) 
- balancês (2)

- cavalinhos (3)

- peixinho (1)

- gangorra (1)

As crianças demonstraram mais interesse em relação a alguns brinquedos e fizeram desenhos sobre os amigos do parque, contando, posteriormente para mim, os fatos vivenciados por elas nas cenas criadas.

\section{Comentários}

Percebi grande interesse das crianças em relatar histórias sobre suas vivências com os amigos no parque. O grande centro de atração parece ser os brinquedos que dão margem ao maior número de participantes, como as casinhas, por exemplo. Estar junto continua sendo a constante também neste espaço, demonstrando que só variam as especificidades de brincadeiras, mas a essência da amizade aqui, também, permanece. Continuarei as entrevistas sobre as histórias das crianças na próxima sessão, pois nesta não foi possivel, devido aos relatos extensos de muitas crianças, ultrapassando o tempo que eu previa, mas fiz questão de deixá-las falar e contar suas histórias livremente

\section{Vigésimo oitavo dia $-5 / 11 / 98$}

Objetivo

Continuar a discussão sobre as questões da sessão anterior, anotando as histórias das crianças sobre os amigos do parque.

\section{Descrição}

Quando cheguei à sala de atividades e cumprimentei as crianças, elas pediram-me para cantarmos "Boa tarde, amigo". E assim foi feito.

Alana perguntou se eu iria continuar a perguntar sobre as histórias dos amigos do parque porque ela ainda não tinha falado a sua história

Expliquei às crianças que todas contariam suas histórias e então recomecei o trabalho de registro que havia interrompido na sessão anterior.

Relatarei, a seguir, todas as histórias contadas pelas crianças sobre os amigos do parque. As crianças foram chamadas, individualmente, na biblioteca e contaram-me suas histórias, olhando e apontando cenas do desenho que haviam feito.

\section{AMIGOS DO PARQUE}

lury: Aqui é o Eduardo no cavalinho. Eu tava na cabecinha do cavalo equilibrando... Nathan Rodrigues tava na piscina de bolinha escondido. Ele está na rede e vai se jogar e cair na piscina. Tem uma tartaruguinha em cima da piscina. É de brinquedo. Se brincar com a gente, o outro não se machuca. Eu brinco de Dragon ball...é só catar, segurar, fingir que a pessoa está presa. Aí vem alguém 
salvar. E ai eu finjo que sou o Hulk e salvo os amigos porque sou forte... Foi meu pai que ensinou. E eu faço karaokê.

Vitor: Era eu e o Ivã brincando no cavalinho. Gosto de brincar com ele. Tinha um brinquedo que aparecia e mostrava a lingua. Era um negócio que ficava em cima da casinha e faz fumaça. Na casinha estava eu, a Karen e o Ivã. Só aparece o Ivã porque ele estava contando 1,2,3,4,5....dentro da casinha, até, ah, era até 100. Eu e a Karen estávamos brincando de esconde-esconde. O sol e a nuvem aparecem para fazer muito calor no parque.

Karen: Aqui na casinha é a Alana e o Júlio. Eles estão brincando de espiar eu, o Nathan e a Aline. Eu tava brincando na gangorra com a Luana e o Nathan Marinho. Eu tava no meio. Ai, depois a Luana me deu um presente no parque. Era uma bola de vôlei. E eu chamei o Júlio e o Nathan Marinho para brincar. Aí, eu e o Júlio ganhamos da Luana e do Nathan de 2 a 0 porque eles não sabiam brincar. Ai, a Alana falou para o sol conversar com a gente. E ele disse que gostava de todo mundo da classe. Gostava da gente porque a gente fazia carinho em todos os amigos da classe. O sol falou que ele era colorido porque ele gostava de azul e amarelo. - Então, daqui a pouco eu vou desaparecer porque eu preciso falar com papai do céu e com Deus. (sol). - Aí, eu falei pra ele que rezava toda noite e ele ficou feliz. A nuvem também falou que todo mundo era amigo, mas ele estava de costas

Nathan Rodrigues: A Leticia (boneca rosa) estava em cima da casinha se escondendo da Karen porque a Letícia era a ladrona e a Karen era polícia. A Alana (boneca azul) era uma rainha que quase matou todo mundo porque ele tinha o poder que fazia vento e derrubava todo mundo. Ela derrubou todo mundo. Só sobrou eu, Leticia, Karen, Eduardo, Nathan Marinho e a Luana não escapou porque ele está escondida aqui embaixo (mostra o desenho). Eu estava brincando de detetive com o Eduardo. Ele pulou da escadinha e eu fiquei escondido para matar a Alana que era a rainha do mal. O Nathan Marinho estava sozinho no escorregador. Ai, a rainha Alana morre de mentirinha e Nathan Marinho também porque estava trabalhando para Alana. É legal brincar todo mundo junto porque é diferente. A gente pode brigar, morrer e depois reviver e ficar tudo bem. Pode ser polícia $e$ lembrar das coisas boas e não cansa. No outro dia, a gente faz a mesma coisa. Todo mundo vive feliz para sempre (Figura 17- Anexo: p. 216).

Júlio: Aqui é o Nathan Rodrigues (boneco verde à esquerda). Do lado é a Gabriela. Do lado o Eduardo e aqui sou eu (último boneco). Estamos brincando na piscina. Aqui (marrom) é o Nathan Rodrigues e a Gabriela brincando de Power Rangers. Aqui é o Eduardo (retângulo roxo) e a Leticia no balancê e do outro lado sentada a Alana. Na casinha e no escorregador estão: a Gabriela, Victoria, Karen, Jéssica, Thalita, Luana, Leticia e Cristiane e a Luana. O sol está bravo porque está muito quente, por isso eu fiz de cor de abóbora e depois amarelo. Eu pus o meu nome dentro da nuvem. Todos do parque são amigos (Figura 18- Anexo: p. 216).

Leticia: A tia Viviane levou a gente no parque. E a gente ficou brincando. Eu e o Eduardo ficamos no cavalinho. Eu, Victoria e a Gabriela ficamos embaixo da escada. A Alana e o Júlio ficaram no balancê. Os outros ficaram na piscina. Nós ficamos na casinha o dia inteiro e depois fomos para casa. A sombra da tia Viviane fiou assim preta porque não deu para desenhar ela no papel. Não tinha lugar. Deixa 
eu ver quantas linhas deu a minha história? Uma, duas, três doze)

Luana: Eu e a Leticia brincando. Nós somos amigas porque brincamos juntas sempre. Tem escorregador e piscina de bolinha, mas ninguém brincava porque estava fechado nesse dia. Dois parquinhos só estavam abertos. O peixinho estava aberto e ninguém brincava. Os outros estavam no banheiro. É mais legal brincar todo mundo junto. Nesse dia, as nuvens cobriram o sol e começou a chover. Então nós corremos para a classe.

Cristiane: Aqui era piscina de bolinha. Era a Gabi, a Lê, eu que estávamos brincando de bruxa na casinha e no escorregador. A gente escorregava bastante $e$ depois ia pra casinha. O Eduardo era o leãozinho. O Ivã era o homem do bem que ficava brincando. Tinha a Karen que era do bem. Ser do bem é ser legal. Ser legal é... como é mesmo...é...Ser legal é quando se tem um pirulito e a gente dá pro amigo. Tem o Ivã, a Karen e o Vitor e a Lê no escorregador. Esse é aquele cavalinho verde. Fiz coraçãozinho pras duas coisas: enfeitar e ser coração do amigo. O Edu fica assustando. A gente pegava bolinha e fingia que era ossinho e dava de mentirinha pra ele comer. Não sei se ele gostava porque não falou para mim. A pedra derretia e, quem era do mau, se pegasse a pedra de quem era do bem, morria. Eu inventei essa brincadeira e eles gostaram e começaram a brincar. Eu era a chefe das bruxas. Eu pedia para a Lê pegar o Ivã e a Karen. Ai, o Ivã tentou me pegar, mas eu pulei do escorregador e consegui escapar. Ai, eu peguei a vassoura e fui embora. Tinha um chefe de mentirinha e falava pra gente fazer as coisas

Murilo: O Nathan Rodrigues está dentro da casinha brincando comigo. As outras crianças estavam nos outros brinquedos. Não sei direito qual. Não me lembro. A tia Viviane fica na portinha olhando a gente. Eu e o Nathan brincamos de conversar sobre o parque. Nesse dia estava muito sol. Eu gosto quando está mais ou menos quente

Eduardo: Esse aqui é o Nathan Marinho brincando na casinha de cachorrão. Ele já até me mordeu. Não sei por quê... A Gabriela e a Victoria estão no balancê. A Leticia e a Jéssica e a Thalita estão no escorregador. Aqui é o Nathan Rodrigues (boneco amarelo)brincando. Eu brinco, às vezes, sozinho porque ninguém quer brincar comigo. Mas eu prefiro brincar com os amigos. É mais legal e eles me ajudam. Eu escrevi Nathan, Leticia, e Jéssica. O resto, o Nathan Rodrigues me ajudou a escrever.

Alana: Eu desenhei uma casinha para você, pra tia Vivi e pra todos os amigos. Tinha uma árvore no parque e era da praia. Estava escrito: "não pise na grama". A gente ia com cuidado e brincava de roda-roda. Cada um subia em cima do outro pra poder pegar as frutas. Tinha fumacinha na casa e estava escrito "amigos da casinha da Alana". E eu falei: - Por que a gente não fica amigo? Ai, todos concordaram e ficaram amigos. Ai, você e a tia Viviane falaram também pra gente ser amigos. Cada um brincava um pouquinho, um de cada vez: na gangorra, no balancê porque tinha brinquedo que só dava para dois. Ai, fizeram suco de maçã, colocaram adoçante e cada um tomou um pouco. E, também, na Páscoa, , no Natal e no dia do indio e no dia das Mães, todos ganharam presentes. Todos ganharam 
presentes no dia do aniversário que era no mesmo dia. Ai, o sol falou pra nuvem: - Vamos tomar um chazinho quente? E ela gostou muito porque era chá de laranja. - Parabéns, vocês não falaram nenhum "pio", na lição...falou a tia de Inglês...fazer "pio" é conversar... Os amigos concordaram em não brigar pra não ir pra diretoria. Essa é a parte mais importante da história. Eles queriam não brigar de verdade, mas também era pra não ir pra diretoria.

Após registrar os relatos das crianças, fomos para o parque e observei-as durante todo o tempo, aproveitando o momento para fotografá-las (Foto 23- Anexo: p. 222). Esta atividade parece ser de grande alegria e satisfação para todas as crianças, sem exceção. Todas brincaram em grupos e fizeram questão de fazer "pose" para serem fotografadas (Foto 24- Anexo: p. 222).

\section{Comentários}

Fiquei, ainda, mais admirada com a capacidade de criação, imaginação e adaptação de vivências pessoais das crianças às suas histórias. A presença de fatos marcantes de outras histórias aliados à proposta do tema "amigos no parque", trouxe à tona várias sensações e pontos de vista das crianças. Alana, por exemplo, parece associar sua história a uma das cenas do livro "Amigos", quando os personagens se sobrepõem para apanhar cerejas em um árvore. Nathan Rodrigues, que na classe parece não ter muita afinidade com Alana, transforma-a em rainha das bruxas e chega a citar sua morte, de mentirinha. Ivã que é muito querido por todos os colegas aparece sempre como "do bem". Nathan Marinho, o recémchegado, apresenta-se no parque, isoladamente, conforme os desenhos e fatos narrados pelas crianças. Outro ponto que chamou minha atenção foi a presença considerável do animismo nas histórias relatadas, quando as crianças dão vida a seres da natureza como o sol e as nuvens, incluindo, inclusive, a fala dos mesmos em suas narrativas. Nesta sessão, a capacidade de imaginação das crianças superou minhas expectativas. Os amigos do parque continuam sendo os amigos para sempre, apesar de toda e qualquer divergência relatada. As situaçōes mudam, porém a essência da AMIZADE permanece, seguramente, segundo a opinião das crianças

\section{Vigésimo nono dia - 10/11/98 Objetivo}

Identificar o que havia ficado de mais marcante, de modo geral, para as crianças, sobre o que é ser amigo em toda e qualquer situação.

\section{Descrição}

Quando cheguei à classe, as crianças estavam terminando uma atividade. Cumprimentei-as e aguardei.

A seguir, começaram a cantar a música "Boa tarde, amigo". Perguntaram se eu contaria nova história e comentei que elas mesmas fariam histórias com novos amigos que iriam ser apresentados: os fantoches.

Algumas crianças já haviam participado de atividades com os fantoches pequenos, mas os daquele dia eram grandes e bem diferentes. Todos ficaram curiosos e não viam o momento de subirmos para começar a brincadeira. 
Perguntei às crianças como poderiamos chamar aquela atividade. Várias sugestōes apareceram: Festa do amigo... Dia do amigo...Amigos do Zôo...A sugestão vencedora foi "Dia do amigo".

A seguir, subimos e fizemos um sorteio com os nomes das crianças. Cada uma tirou um papel com o nome de um colega, dando a chance de cada um escother um amigo fantoche, entre todos os outros, que estavam encostados na parede esperando para brincar com as crianças.

inicialmente, manusearam livremente os fantoches, brincando com os colegas pulando, dançando, demonstrando grande entusiasmo. Depois pedi para que pensassem no que os amigos fantoches do faz-de-conta poderiam estar pensando. o que estavam conversando e do que estavam brincando, e que nomes poderiam dar a eles

As crianças dividiram-se em grupos espontâneos para brincar e criar suas histórias (Fotos 25 e 26- Anexo: p. 223). Seus relatos foram registrados conforme a lista que segue abaixo.

\section{O DIA DO AMIGO}

Grupo 1: Gabriela, Jéssica, Cristiane, Victoria, Alana, Luana, Leticia. João, Ema

Nomes dados aos fantoches: Renato, Gabriela, Soneco, Victoria, Gabi,

Relato: Estamos brincando... Vamos brincar de corre-cutia? Vamos passear? Vamos cantar? Boa tarde amigo..

\section{Grupo 2: Thalita e Vitor}

Nomes dados aos fantoches: João Francisco e Eduardo Gonçalves de Abreu (que nem o fim do meu nome - acrescenta Vitor).

Relato: A gente brinca de pegar um no outro. Brinca de dar abraço. Aí eu corria para o João Francisco não me pegar. Mas era de brincadeirinha... Aí, ele chamou o João, cara de melancia e cara de vampiro, mas ele gostou porque sabia que era de brincadeirinha porque ele era amigo, gostava de brincar..

Grupo 3: Murilo, Júlio, lury, Nathan, Eduardo.

Nomes dados aos fantoches: Eduardo, Jacaré-pagua, Macaco Chico, Tartaruga Rafael, Fábio.

Relato: A onça está tentando atacar o macaco. O Fábio estava tentando pegar a tartaruga, mas ela se escondeu dentro do casco. Depois ela apareceu com a cabeça e o menino mordeu o pescoço dela e ela morreu. Depois ela ficou viva de novo e os dois ficaram felizes para sempre. Ela reviveu porque ela foi para o céu e encontrou Deus e ele Ihe deu um remédio que ela viveu de novo. 
As crianças demonstraram bastante interesse e entusiasmo por essa atividade e não queriam retornar à classe, mas já estava na hora da saida e tivemos de voltar

Fiquei um tanto decepcionada ao saber que o aluno recém-chegado, Nathan Marinho, havia saido da escola. Segundo a diretora, sua tia alegou que a familia estava passando por dificuldades. As crianças ficaram tristes, pois já o consideravam com mais um amigo e sua saida, para todos nós, representou uma perda, justo agora que estava começando a se adaptar realmente à classe. Conversamos e elas demonstraram esperança de que o amigo voltaria, no próximo ano, e, assim, preferimos acreditar

Despedi-me das crianças, naturalmente, como de costume o faço a cada sessão. Preferi não me despedir, de forma definitiva e conclusiva como se fosse o momento final do projeto, pois, na verdade, considerava estar encerrando a etapa inicial de um significativo trabalho de aprendizagem, que, posteriormente, conforme solicitação da escola, dos pais e por meu próprio interesse, pretendia compartilhar com elas

Ao final do periodo, houve uma reunião com os pais dos alunos, conforme eu havia solicitado à Direção, na semana passada.

Os pais compareceram em grande maioria (catorze presentes, três ausentes). Iniciei a conversa agradecendo a presença de todos e, principalmente, pelo incentivo e apoio dado à realização do meu projeto na escola com os filhos deles

Pedi para que comentassem sobre o desenvolvimento do projeto junto às crianças e eles disseram que elas viviam falando sobre as histórias em casa, cantando as músicas e explicando sobre o comportamento dos personagens das histórias

Conversamos sobre a importância do contar história para o desenvolvimento da criança e, também, sobre a formação de Valores Humanos. Os pais solicitaram a continuidade do projeto para as séries posteriores de ensino, no próximo ano. Disseram que eles é que deveriam agradecer.

Entreguei aos pais a bibliografia utilizada no projeto (livros das histórias apresentadas) e as letras das músicas que cantávamos acompanhando algumas histórias, conforme eles haviam solicitado. Uma das mães sentiu falta de uma música: - Está faltando a galinha pintadinha...disse ela. Prometi que enviaria posteriormente junto com o livro-lembrança que cada criança da classe iria receber.

Os pais vieram despedir-se, pessoalmente, e me coloquei, mais uma vez, à disposição para todo e qualquer incentivo referente ao trabalho com as crianças, no presente projeto.

\section{Comentários}

A atividade com fantoches nesta sessão foi muito gratificante para mim. As crianças foram capazes de sintetizar através dos fantoches aquilo que pensam sobre os amigos, pela maneira como se posicionaram nas falas dos relatos e até mesmo na criação de nomes, muitas vezes iguais aos dos amigos. O brincar junto permaneceu como a essência da amizade, assim como o faz-de-conta, a presença da mentirinha para que no final todos os amigos sejam perdoados, possam reviver 
(caso tenham sido mortos de brincadeirinha...) e, finalmente, vivam felizes para sempre. As crianças têm consciência das falhas e imperfeiçōes dos amigos, brigam por elas, mas, também, têm certeza de que querem continuar amigos, pois tudo isso faz parte da amizade e, ainda, devido a um fator de considerável importancia: as crianças não suportam ficar sozinhas.

Esta primeira etapa foi finalizada devido ao término do tempo previsto para conclusão do estágio supervisionado; no entanto, posteriormente, pretendo continuar e aprofundar o trabalho, se possivel no próximo ano. Acabei criando um vinculo de AMIZADE e afeto muito forte com as crianças e os demais integrantes da escola. Acredito que tudo isso tenha contribuido para que não me despedisse de maneira formal ou definitiva, e, também, por ter sido convidada para participar da confraternização de encerramento do ano letivo da escola, no início de dezembro. Sendo assim, iriamos nos encontrar, novamente, em breve.

\title{
Reflexões ao encerrar as sessões para implementação do projeto
}

\author{
' O que está à disposição dos professores hoje \\ é um corpo de conhecimentos que, se não dá conta de tudo, \\ pelo menos ilumina os processos \\ através dos quais as crianças conseguem ou não \\ aprender certos conteúdos. \\ Já é possível observar uma situaçāo de sala de aula \\ e interpretar as ações das crianças e do professor \\ com um grau de profundidade que não existia antes. \\ Cada vez mais a concep̧̧ão que se tem do ato de ensinar \\ desenha o perfil de um professor que reflete enquanto age, \\ pode tomar decisōes, mudar rapidamente o rumo de sua ação,
} interpretar as respostas que os alunos dão, autocorrigir-se.

Telma Weisz

A escolha do tema do presente projeto surgiu do grande interesse que tenho em relação à literatura de modo geral, $e$, principalmente, em relação à literatura infantil.

Conviver com as crianças representa, para mim, um enorme prazer e um processo constante de aprendizagem. A idéia de trabalhar com histórias infantis e valores humanos nasceu de minha experiência como educadora. Percebi, ao longo dos anos, no convivio com as crianças, que há um espaço para reflexão, a partir de cada história que lemos ou ouvimos alguém nos contar, favorecendo a transformação de atitudes através dos valores contidos na narrativa. Sendo assim, jamais somos os mesmos depois de ler ou ouvir uma história. 
Antes de fazer uma reflexão geral sobre o projeto aqui exposto, considero importante realizar um breve retrospecto das etapas nele vivenciadas, mesmo considerando-se que esta evolução já tenha sido explicitada, anteriormente, de forma mais minuciosa.

Quando apresentei meu projeto à minha supervisora de estágio, fui orientada para que tivesse o cuidado de não direcionar o trabalho com as crianças, utilizando. apenas minha visão de adulto, pois estaria perdendo a valiosa oportunidade de conhecer o que elas podem expressar por si mesmas.

Dessa forma, o meu contato inicial teve o intuito de avaliar a proximidade que tinham com o mundo das histórias infantis, que tipo de temas jả conheciam ou demonstravam maior interesse.

Além disso, observava, simultaneamente, o comportamento e as reações do grupo para selecionar, realmente, os valores a serem trabalhados a partir das histórias apresentadas

Embora já tivesse delineado, no projeto, alguns valores que considerava importantes para as crianças, em geral, e, também, as histórias infantis, estava disposta a fazer qualquer tipo de alteração do plano inicial, caso o grupo assinalasse para outra direção, pois já havia sido orientada, no início das sessōes de supervisão de estágio, sobre a possibilidade de alterações que se fizessem necessárias no decorrer do trabalho

Após ouvir as histórias das crianças e fazer um levantamento sobre os vários tipos de leituras que apreciavam em livros e, até mesmo em gibis, selecionei os dez Valores Humanos que me pareceram ser do interesse geral do grupo, ratificando a lista inicial que havia previsto: ORDEM. CORAGEM, GRATIDĀO: INICIATIVA, PERSEVERANÇA, SOLIDARIEDADE, COOPERAÇĀO, ESFORÇO, RESPEITO. PERDÃO. As histórias infantis que abriram o caminho para este trabalho de formação de valores estão mencionadas no plano inicial da apresentação do projeto e, também, na bibliografia referente a esta pesquisa.

Minha proposta de trabalho era explorar ao máximo as histórias apresentadas, buscando atividades relacionadas às mesmas, a fim de suscitar, simultaneamente, a reflexão das crianças sobre os diversos Valores Humanos presentes em cada história.

As atividades desenvolvidas envolviam desenho, pintura, modelagem, fantoche, música, sempre permitindo ou incentivando muita discussão e comentários por parte das crianças. Procurava registrar todas as colocaçōes das crianças para que, a partir dai, pudesse redirecionar as sessões de estágio, se necessário

Realmente, a cada sessão, as crianças contribuiam com um novo enfoque para discussão ou demonstravam a necessidade de aprofundamento em determinados valores.

No projeto inicial, minha intenção era a de explorar, também, em casa, a observação dos valores no comportamento das crianças. Para tal, pedi a elas que prestassem atenção em tudo o que faziam em casa que se relacionava com as histórias e o comportamento dos personagens nas mesmas: ordem e organização, esforço, colaboração etc. 
No entanto, com o desenvolvimento do projeto, comecei a perceber que as crianças traziam-me somente fatos positivos sobre o comportamento delas. Nas sessões de supervisão, fui questionada se isso não significaria que elas estivessem tentando corresponder à minha expectativa de adulto, como uma forma até mesmo deliberada de me agradar.

Sendo assim, refleti sobre esta questāo e conclui que o meu objetivo nāo era este, mas sim perceber o que realmente as crianças "pensavam" e "sentiam" , ou o que era mais importante e significativo para elas em relação aos Valores Humanos. contribuindo para uma reflexāo delas sobre isso, no dia-a-dia, nas relaçōes intra e interpessoais.

Por tudo isso, a partir da $10^{a}$ sessão de estágio, aboli as tarefas de casa que havia previsto inicialmente. Considerando que seria mais importante despertar pontos de reflexão nas crianças, minimizando a possibilidade delas buscarem fatos positivos (assim determinados por elas) para me apresentar.

A cada sessão, procurava perceber "as pistas" que as crianças estavam oferecendo-me para aprimorar as propostas do projeto.

Observei que, embora todas as atividades estivessem transcorrendo de forma prazerosa e motivada, as crianças podiam dizer-me mais sobre suas próprias concepções em relação aos valores. Mas como fazer isso? Como chegar a esta proximidade e captar o mundo das concepções infantis sobre os Valores Humanos?

Já havia chegado na $16^{\mathrm{a}}$ sessão, com todas as histórias e valores humanos trabalhados, conforme plano inicial, e ainda não estava segura de ter atingido o objetivo principal que era saber o que, realmente, sentiam e consideravam sobre os valores humanos. Qual seria, então, o real mundo interior de valores para elas? enfoque

Sendo assim, optei por continuar o trabalho dando ao projeto um novo

A primeira idéia, para enfrentar este desafio de dar uma guinada no projeto, ou seja. ampliá-lo sob um novo enfoque, surgiu através do trabalho com livros sem texto, onde as próprias crianças contavam as histórias, a partir das ilustrações apresentadas. Houve uma contribuição muito valorosa das crianças, pois ao relatar as histórias, juntavam fatos de suas vivências anteriores e, até mesmo, de muitos valores já assimilados por elas como ser justo, afetuoso, amigo...

Durante o trabalho com os livros sem texto, percebi que as crianças demonstravam um grande interesse sobre a questão da amizade e da afetividade. Senti que esta seria uma pista valiosa para o aprofundamento do trabalho, pois era um assunto muito discutido e presente no cotidiano do grupo.

Assim, acrescentei ao plano inicial dois valores AMOR e AMIZADE. As crianças demonstraram um especial interesse pelo livro "Amigos", e, partir dele, percebi que a chave para uma ampliação significativa do projeto, conforme 0 interesse demonstrado pelas crianças, seria o Valor Humano: AMIZADE.

A partir da mensagem de AMIZADE vivenciada pelos personagens da história, comecei a buscar respostas, junto às crianças, para perceber o significado de questões como: o que é ser amigo, como brincar de amigo e, ainda, observar a demonstração desse valor em diferentes situações ou ambientes mais marcantes do espaço escolar (na classe, no refeitório, no parque). Minha intenção era a de 
perceber e comprovar a consistência ou inconsistência do que as crianças diziamme sobre AMIZADE. Pretendia verificar se as atitudes delas, em relação aos amigos, seriam iguais ou diferentes, em ocasiōes e lugares diversificados.

No decorrer deste trabalho de sondagem e levantamento de concepções infantis sobre a AMIZADE. por intermédio de uma metodologia indicial, adotada por um assinalamento feito pelas próprias crianças, elas insistiam em pedir mais histórias e embora o meu objetivo, naquele momento, fosse mais de ouvi-las e observá-las, registrando e colhendo importantes opiniões que me forneciam, considerei que poderia, ainda, trabalhar uma outra história, desde que enfocasse e reforçasse o valor AMIZADE, que estava conduzindo, na ocasião, como carro-chefe, o novo enfoque resultante da guinada dada ao projeto.

Dessa forma, pesquisei mais alguns livros e consegui encontrar uma história maraviihosa, cujo enfoque central era a AMIZADE entre um enorme dragão e um pequenino ratinho: "O livro do dragão".

As crianças fizeram desenhos e me relataram fatos, a partir desta história, que expressaram, ainda mais, sua visão sobre o que é ser amigo

Os relatos das crianças fizeram-me compreender que a amizade é algo muito significativo e também, indispensável para elas. Inicialmente, parecia haver uma certa instabilidade ou contradição entre o que elas diziam (amigo é não bater, não brigar, não ficar de mal) e o que faziam no dia-a-dia (reclamar do colega, brigar porque o colega empurrou, disputar o brinquedo que a professora ofereceu... etc). Em sessão de supervisão, pude olhar para esta aparente contradição, a partir de outro enfoque ser amigo é ser tudo isso, ao mesmo tempo e continuar, com e apesar de tudo, amigo: juntos para sempre, ou seja, para as crianças é inconcebivel ficar só o que parece, para elas, ser o maior castigo ou punição.

Durante o desenvolvimento do projeto, as crianças demonstraram terem refletido muito sobre os Valores Humanos. Percebi mudanças consideráveis como a importância do respeito, da colaboração, do companheirismo, da organização da classe, do material enfim. de todas as discussões decorrentes de nosso trabalho, a partir dos fatos relatados nas histórias apresentadas.

As histórias infantis são, realmente, de grande valia para o educador, pois, através delas, as crianças se expressam mais livremente, estabelecendo nitidas relações entre a vida delas e a dos personagens da narrativa. Sendo assim, o educador pode planejar e replanejar as atividades propostas para o trabalho com as crianças, por intermédio de dicas que elas oferecem e demonstram, a partir das histórias, auxiliando e favorecendo o encaminhamento do processo de ensinoaprendizagem.

A partir das histórias e de vivências compartilhadas, as crianças demonstraram uma extraordinária capacidade de sintese e grande sensibilidade, ao fazer seus relatos sobre as questões relacionadas à AMIZADE. Elas foram capazes de englobar, de forma natural e espontânea, tudo o que discutimos anteriormente e muito mais, superando as minhas expectativas, no que se refere à observação, seqüenciação e coesão de idéias, riqueza de vocabulário e, principalmente, a uma significativa sabedoria direcionada às concepções de AMIZADE. As crianças conseguiram reunir, simultaneamente, todos os Valores Humanos propostos e, também, os não propostos no projeto. 
Dentre todo o riquissimo material registrado nos relatos das crianças, a partir dos desenhos por elas elaborados, alguns me sensibilizaram mais profundamente:

- Eduardo, meu amigo...Meu primo, Guilherme... Eles estão brincando no quintal e na praia. Eles estão dentro do coração (Júlio)

- Aqui sou eu e meu irmão. Eu gosto do meu irmão quando ele faz palhaçada. Eu quero falar que eu amo minha irmã e meu irmão. Tiago... O Ivã era do bem que ficava brincando. Tinha a Karen que era do bem. Ser do bem é ser legal. Ser legal é quando se tem um pirulito e a gente dá pro amigo (Cristiane).

- Eu brinco. às vezes, sozinho porque ninguém quer brincar comigo. Mas, eu prefiro brincar com os meus amigos. É mais legal e eles me ajudam (Eduardo).

- Ai. a Alana falou para o sol conversar com a gente. E ele disse que gostava de todo mundo da classe. A nuvem também falou que todo mundo era amigo...(Karen).

- É legal brincar todo mundo junto porque é diferente. A gente pode brigar, morrer e depois reviver e ficar tudo bem. Pode ser polícia e lembrar das coisas boas e não cansa. No outro dia a gente faz a mesma coisa. Todo mundo vive feliz para sempre (Nathan Rodrigues)

As crianças conseguiram responder às minhas questōes sobre o significado dos Valores Humanos. Demonstraram que são capazes de vivenciar situaçōes intensamente, a partir de uma grande riqueza de sentimentos, emoçōes e vontade de viver, plenamente, cada oportunidade oferecida

MARTINELLI (1996), na citação abaixo, forneceu-me um importante material para a reflexão sobre todo o trabalho do projeto compartilhado com as crianças:

(...) Os valores humanos são fundamentos morais e espirituais da consciência humana. Todos os seres humanos podem e devem tomar conhecimento dos valores a eles inerentes. A causa dos conflitos que afligem a humanidade está na negação dos valores como suporte e inspiração para o desenvolvimento integral do potencial social. Não é possivel encontrar o propósito da vida sem esses valores que estão registrados em nosso ser profundo, ainda que adormecidos na mente e latentes na consciência. Os valores são a resena moral e espiritual reconhecida da condição humana.

A vivência dos valores alicerça o caráter, e reflete-se na conduta como uma conquista espiritual da personalidade. No dinamismo histórico, os valores permaneceram inalteráveis como herança divina em cada um de nós, apontando sempre na direção da evolução pelo autoconhecimento. Nesse grandioso drama humano, criado por nossos erros e acertos, os valores abrem espaços e trazem inovações essenciais para a sobrevivência da espécie e o cumprimento do papel do ser humano na criação. Vivemos tempos críticos, violentos e desesperados; isso acontece devido ao fato de grande parte da humanidade ter esquecido seus valores e tê-los considerado até ultrapassados e desinteressantes. (...)" (p.15)

$\mathrm{Na}$ verdade, depois de todo o trabalho desenvolvido com as crianças, cheguei à conclusão de que o grande impacto no comportamento das mesmas aconteceu em decorrência do processo de reflexão pelo qual passamos, aliando os fatos das histórias infantis, dentro do eixo básico da vasta riqueza e amplitude da literatura, aos Valores Humanos presentes em cada uma delas. 
A cada encontro, as crianças traziam-me questões e, ao mesmo tempo, afirmações que contribuiam para que eu fosse me aproximando do significado dos Valores Humanos para elas.

Ao final desta etapa do projeto, senti maior compreensão das crianças como integrantes importantes do grupo, além de um significativo crescimento em relação à auto-estima delas. Tenho certeza de que este impacto reflexivo, certamente, também me afetou profundamente.

Este projeto ajudou-me a perceber, claramente, que o caminho da reflexão, na busca do autoconhecimento, é algo inerente a crianças e adultos. Juntos, compartilhamos, dia-a-dia, 'erros e acertos', que nos transformam e nos modificam, a cada instante, através de vivências relacionadas a todos os Valores Humanos.

Essa partilha ininterrupta de 'erros e acertos' é indispensável para o equilibrio interior. Para mim, o que dividi e aprendi com as crianças neste trabalho, representa um caminho sem fim e sem volta, que torna a vida mais colorida, significativa, plena e feliz.

Por tudo isso, as crianças me inspiraram a escrever uma poesia - resultado de uma reflexão inquietante, gradativa e cumulativa, elaborada ao longo deste projeto - que, a elas, dedico:

\section{O valor da criança}

Aprendi com as crianças

Que os valores humanos existem para todos

É algo mais forte do que eu imaginava:

A ordem, o perdão, a solidariedade,

O respeito, a cooperação ...

A amizade!

Como esse valor é poderoso, forte e significativo...

Que maravilha (re) descobrir

O valor da criança

E quanto importa o outro...

Mas

- O que é ser amigo?

- É brincar junto, não brigar, ficar perto de mãos dadas..

No quintal, na praia, na escola, na casa da avó...

Dormir na casa do outro...

Emprestar coisas....

Dividir o lanche...

Estar dentro do coração.

Aprendi com as crianças

Que elas são mais transparentes e espontâneas

Do que eu imaginava! 
Para elas, expressar a amizade

Através do desenho, da fala e da ação

É coisa simples

Percebi que ser amigo é

Dividir bons e maus momentos

É discutir brigar às vezes, mas, mesmo assim

Continuar junto!

$\mathrm{Na}$ verdade a amizade é tudo ao mesmo tempo:

É a criança por inteiro

É o valor que resiste às intempéries do dia-a-dia

Na classe. no lanche, no parque.

Mesmo com todas as desavenças tipicas

do relacionamento humano

O amigo permanece... firme e constante!

Para as crianças não existe algo pior

Do que ficar só

É vital superar as dificuldades

$E$, ainda, continuar amigo!

Uma criança diz

- Eu quero falar que eu amo minha irmã e meu irmão!

Aprendi com as crianças

Que as declarações de amor

São mais fáceis de serem ditas!

Que ser espontâneo è natural!

Que cantar faz parte das histórias...

E que as histórias

Dão um colorido especial à vida!

Que o mundo da fantasia

Atrai, motiva e auxilia a enfrentar

Muitas dificuldades da infância...

Para a criança

O valor humano de mais valor

É aquele que, aparentemente,

Não tem valor:

- é o dragão ganhar amigos mais importantes do que um belissimo rádio de pilha disputado em um concurso no zôo...

- é o pintinho pequenino enfrentar obstáculos

ser criticado, desacreditado, mas chegar à sua meta...

- é continuar construindo casas como os três porquinhos,

mesmo com a interferência do lobo mau,

até conseguirem um abrigo seguro!

- é também não concordar, discutir, duvidar,

refletir e, assim, continuar, ainda juntos:

Amigos para sempre! 
Esse vai-e-vem da vida

É a mola propulsora

Das relações infantis

Estremece, fragmenta, desestrutura e reestrutura

É um jogo simbólico de buscas interiores

De grandes e ricos valores

Expressos em diferentes situações

Que, ao mesmo tempo:

Enriquece, aprimora, lapida, solidifica, constrói

E transforma

As crianças contaram-me

Uma belissima história de valores...

Com elas

Aprendi muito mais

Do que, supostamente,

Ousei tentar ensinar!

\section{Segundo momento da pesquisa: a retomada do projeto na trajetória das crianças envolvidas (a influência do processo de alfabetização) $-1^{\circ}$ Semestre de 2000}

' Grande é a poesia, bondade e as danças.

Mas o melhor do mundo são as crianças.'

Fernando Pessoa

Considerando o envolvimento das crianças no Projeto de Literatura Infantil e Valores Humanos, surgiu a idéia da retomada da pesquisa, mesmo após o término 'oficial' dos encontros sistemáticos que havia combinado com as crianças. Isto porque, continuei mantendo contato com elas, com os professores, diretora, coordenadora e funcionários da escola, onde desenvolvemos o projeto, em ocasiões posteriores: reuniões, palestras com pais, festas e eventos culturais.

Dessa forma, pude perceber que as crianças perguntavam sobre a continuidade das histórias que eu Ihes contara, pedindo para que eu voltasse à classe e continuasse os nossos encontros.

As professoras das outras classes de Educação Infantil, além daquela em que eu havia desenvolvido a pesquisa, e, também, de outros niveis de ensino, deram início ao Projeto de Literatura e Valores Humanos - trabalhando com os alunos histórias com temas de interesse para os mesmos. A direção, juntamente com os professores da escola, iniciou a divulgação dos trabalhos das crianças, expondo seus próprios textos sobre questões relacionadas aos valores humanos, 
em um jornal exclusivamente destinado às atividades realizadas pelos alunos, que começou a ser muito elogiado pelos pais e pela comunidade em geral.

A partir do inicio de 1999, ficou combinado, por iniciativa da escola, que, a cada mês, seria selecionado um valor humano para ser trabalhado em todos os setores, envolvendo todos os integrantes do ambiente escolar — alunos, professores, funcionários, direção — com produção de diferentes atividades e reflexão sobre as atitudes de cada um em relação ao valor em questão. Concomitantemente, outros valores continuariam a ser vivenciados; no entanto, seria priorizado o enfoque a um valor mensal para aprofundar a discussão e a sua vivência cotidiana

Acompanhando a motivação e o envolvimento de todos da escola e percebendo que o meu trabalho inicial do projeto - como semente da importância da literatura e dos valores humanos - conseguiu desencadear a açāo de tantas produções e idéias significativas, comecei a sentir necessidade de retomar a pesquisa com as crianças em alguns encontros pontuais, praticamente um ano após a pesquisa que desenvolvi com o grupo de maneira continua e sistematizada.

Conversei com a diretora da escola sobre a retomada da pesquisa e ela informou-me que o grupo com o qual havia trabalhado no Pré A, em 1998, contava, agora, em 2000, com praticamente os mesmos alunos. Apenas quatro alunos haviam mudado de escola - Gabriela, lury, Nathan e Victoria. Os demais remanescentes, agora já alfabetizados, na $2^{a}$ série $B$, haviam ganhado mais oito companheiros de classe

Este fato deixou-me bastante animada, pois queria verificar como as crianças estavam, neste momento, vivenciando as histórias e os valores humanos em sua trajetória e, ao mesmo tempo, colocando em desafio minhas próprias vivências, já que me encontrava em um período mais aprofundado da pesquisa.

O fato de o grupo de crianças permanecer praticamente intacto, na classe atual, parecia que muito iria ajudar-me. Outro fator positivo parecia ser o fato de poder retomar o projeto. observando as crianças que eu já conhecia $e$, ao mesmo tempo, a reação das novas crianças, que, ainda, não me conheciam, nem tampouco a proposta do trabalho.

$\mathrm{Na}$ verdade, minha intenção não era a de perpetuar a idéia inicial do projeto, com todos os seus momentos e etapas lineares, mas, de maneira ampla, verificar o significado para todas as crianças das histórias infantis e dos seus valores de vida, enfocando, propositalmente, o valor humano 'amizade', que tanto ficou presente para as crianças, que eu já conhecia de encontros anteriores, durante e após nossas discussōes e vivências sobre as histórias.

Combinei com a direção da escola e com a professora Daniela. que retomaria o trabalho com as crianças da $2^{a}$ série $B$, logo após a primeira semana de aula.

Quando cheguei à escola, fiquei aguardando na diretoria, até que o intervalo para o lanche terminasse para que pudesse ir à sala das crianças. Logo na entrada algumas crianças já conhecidas vieram ao meu encontro, fazendo 'festa' e me pedindo para contar histórias, pois a professora da classe havia contado que eu iria voltar para continuar nossas conversas... As crianças que ainda não me conheciam também vieram falar comigo perguntando se eu era a tia das histórias... elas também pareciam muito ansiosas para ouvir as histórias.

Comecei a perceber e a comprovar que o tempo não é capaz de destituir das crianças o amor e a curiosidade pelas histórias - mesmo após alguns intervalos 
no percurso. Na verdade, a semente que se lança cresce mais vigorosamente do que podemos imaginar.

Para retomar o trabalho e conseguir alguns dados para novas considerações, escolhi algumas histórias relacionadas à amizade, uma vez que as crianças haviam demonstrado especial interesse por este valor humano.

Apresentarei a seguir, as observações que considerei significativas em meus (re)encontros com as crianças da $2^{a} B$

\section{0 de fevereiro de 2000}

Neste primeiro dia de (re)encontro com as crianças, apresentei-me para as novas crianças da classe - Caroline, Felipe, Jessica, Lessandra, Leticia Sarco, Lysa, Mateus e Talita Brasil. Conversei informalmente com as crianças já conhecidas e juntos começamos a fazer o jogo da memória: fiz uma pequena sondagem pelo interesse por antigas histórias que havia contado, detectando que as crianças lembravam da maioria das histórias contadas e que mesmo as novas crianças conheciam algumas em comum que suas professoras anteriores haviam lido para elas.

Percebi que as crianças apresentaram memória significativa em relação às histórias, ou seja, relataram fatos marcantes que se destacaram para elas como inesqueciveis, reforçando o que foi demonstrado no inicio deste trabalho: os educadores adultos declararam lembrar-se de histórias que thes contaram em sua infância e isto também foi exposto através de minhas próprias memórias sobre histórias contadas em minha infância, desencadeando, indiscutivelmente, o meu interesse e a minha paixão pelo mundo da literatura.

Quando iniciamos nossa conversa, Alana, sempre participativa, logo comentou:' - Você esteve em nossa classe contando histórias em 1998 quando era a professora Viviane... eu me lembro da Esquilinha... (Por associação ao título real: A esquilinha caprichosa) Claro! Como é que eu la esquecer dessa história?...), da Festa no céu, dos Três porquinhos.

As outras crianças foram completando: Os três lobinhos (por associação ao titulo Os três lobinhos e o porco mau), A galinha ruiva, A de Amigo, Pela porta do coração, O pequeno dragão (por associação ao titulo O livro do dragão), Amigos...

O que parecia inacreditável era a tranqüilidade com que as crianças lembravam das histórias contando inclusive o enredo das mesmas, detalhando aspectos do ambiente, comportamento das personagens e até as canções que costumávamos cantar relacionando-as às histórias apresentadas.

Depois que conversamos sobre as lembranças que tinham das histórias, as crianças falaram de outras que haviam escutado e lido. Percebi, então, que o interesse pelo mundo da literatura tinha agora um fator de contribuição e incentivo às crianças: o fato de estarem alfabetizadas e poderem ler e escrever suas próprias histórias

Foi por decorrência desta constatação que as crianças desenharam as histórias de sua escolha e a maioria acrescentou textos, espontaneamente, relatando fatos sobre o enredo em questão. (Anexo: pp. 226-7)

Muitas crianças mostraram-se extremamente preocupadas com a escrita correta das palavras, mesmo sem que eu tivesse comentado algo sobre isso. Expliquei-lhes que o que mais me importava era que, da maneira que quisessem e conseguissem, fizessem tudo o que lembrassem das histórias. Percebi que neste momento, as crianças estavam vivenciando os seus próprios desafios na luta e na 
busca da escrita. Algumas chegaram a fazer algumas colocações: "Passear é com dois esses (ss)? Choveu é com 'l' ou com 'u'? Escreve 'tinha'... Dois corações..."

As crianças pediram para que eu contasse uma história nova e combinamos que isso ficaria para o nosso próximo encontro

\section{2 de fevereiro de 2000}

No encontro deste dia, por escolha do valor 'amizade' que havia sido muito explorado, anteriormente, e causado grande interesse nas crianças, decidi levar um livro com as mesmas personagens de uma história sobre amizade que as crianças haviam gostado muito - Amigos, para observar qual a reação delas, neste momento. sobre um valor humano que gerara tanta motivaçāo no grupo. As mesmas personagens - o porco Waldemar, o galo Juvenal e o ratinho Frederico reencontram-se como velhos amigos da história anterior, só que agora o título é 'Os aventureiros

Nesta nova história, os antigos amigos resolveram juntos deixar de viver situações de tédio em suas vidas e acabaram decidindo se aventurar mundo afora em busca de mais animação. Tudo para eles seria possivel, pois eram amigos e sempre poderiam contar com a amizade que os unia.

Inicialmente, as crianças demonstraram muita curiosidade em relação à capa do livro: queriam ver as ilustrações, falar sobre os desenhos e as personagens que para a maioria das crianças eram familiares. Após vários comentários sobre as curiosidades relacionadas aos desenhos da capa, quando as crianças já estavam menos ansiosas, perguntei-Ihes se sabiam o que significava o titulo da história. Algumas disseram que ser aventureiro 'era viajar', outras que 'era enfrentar perigo', mas a maioria defendeu a idéia de que 'para ser aventureiro tinha que ser com o amigo

Foram dados alguns exemplos pelas crianças do grupo anterior e pelo grupo novo, sobre os amigos: ' vivem juntos e um ajuda o outro, passeiam juntos e todos se ajudam, pagam a conta do almoço e da janta, é ter respeito... carinho... ficar junto... conversar...'

Pude constatar que a amizade continuava sendo um valor muito forte para todas as crianças: elas queriam falar sobre os seus amigos e fazer desenhos sobre eles. O que se acrescentou a este interesse pela discussão da amizade foi o interesse pelas palavras novas que apareceram na história. Estas foram indagadas por algumas crianças e colocadas, por mim, como desafio para o grupo responder. Houve a socialização das informações de todas as palavras inqueridas, sem que eu precisasse intervir com o resultado. Apenas tentei mediar, buscando com o grupo, através de outras perguntas e reflexões para que as próprias crianças chegassem à conclusão. As palavras abaixo foram explicadas pelas próprias crianças mediadoras para as outras do grupo que desconheciam algumas definiçōes:

- esterco: cocô de cavalo;

- adubo: é para crescer as plantas;

- ratoeira: para pegar os ratos;

- tédio: o que é uma chatice;

- canibal: que come tudo que vê pela frente...que come gente.

As crianças pediram para desenhar os seus amigos e assim foi feito. Algumas expressaram suas produçōes com acréscimo de pequenos textos ou 
relatos, misturando fatos da história sobre os amigos aventureiros e suas opiniões próprias sobre amizade e seus amigos. Como pode ser verificado, em anexo referente a este encontro, as produções das crianças foram apresentadas, de maneira peculiar por cada uma, com as seguintes caracteristicas (Anexo: pp. 229230):

- Desenho com relatos sobre a história misturados com as opiniões das crianças

- Desenho com expressão através de diálogo em quadrinhos (balões com frases)

- Desenho referente à história, sem apresentação de texto

É importante lembrar que a iniciativa das produções acima mencionadas foi por parte das crianças que, inicialmente, pediram para desenhar e, naturalmente, os textos foram aparecendo como uma necessidade de acrescentar mais uma forma de representação de suas opiniōes.

Neste encontro, percebi, mais forte, a busca da escrita por parte das crianças. como um auxilio de expressão aos seus desenhos, de forma a demonstrar com clareza suas idéias, emoções, valores e reflexões sobre os fatos por elas vivenciados

\section{3 de fevereiro de 2000}

Neste encontro, as crianças receberam-me, ansiosamente, querendo saber o número do meu telefone de casa e também do meu telefone celular.

Murilo perguntou logo no inicio: "- Você tem internet? Tem e-mail?"

Karen completou: "- Posso ligar para você hoje?"

Lisa levantou-se e disse bem perto: "- Engraçado! Faz pouco tempo que te conheço e já acho você legal!" A seguir entregou-me uma cartinha que havia escrito para mim

Acabei percebendo que a ansiedade em relação ao número do meu telefone havia sido desencadeada por Alana que ganhara uma agenda telefônica e estava anotando o endereço e telefone de todos naquele dia. Percebi, também que os laços de amizade e carinho que havia criado com as crianças do antigo grupo estavam mais vivos do que nunca e que as novas crianças já se mostravam bastante próximas a mim também.

O que parece mais interessante nesta situação é que, embora sabendo da receptividade e afetividade de todas as crianças de modo geral, as diferentes histórias do mundo da literatura simbolizam um canal de prazer para as crianças e, nesta perspectiva, eu, como contadora de histórias, parecia ser o veiculo de deleite de todas, a cada encontro que tinhamos.

Conversamos bastante sobre histórias relacionadas à amizade. Muitas crianças lembravam de histórias contadas para elas na escola, muitas pelos pais ou outras pessoas de seu relacionamento familiar.

Neste dia, li para as crianças a história de Billy brigão, um pirata aposentado que aparentemente parecia ser um homem muito malvado e brigão, mas que acabou sendo conquistado pelo amável Paulinho, um garotinho carinhoso e especial... E dai em diante a amizade entre os dois passou a ser para sempre.

As crianças interessaram-se muito pela história, especialmente pelo jeito brigão de Billy, algumas acharam-no engraçado de tão rabugento que era. A maioria queria ver os desenhos marinhos de perto - o unicórnio -do- mar (narval), a casinha da sereia, o homem marinho, o monstro marinho - e se encantaram com a transformação de Billy quando se tornou fiel amigo de Paulinho. As crianças pareciam emocionadas quando Billy fez uma surpresa para Paulinho, 
confeccionando uma pipa nova para o amigo. Pediram para desenhar sobre a história na lousa, fazendo desenhos alusivos ao enredo e escrevendo algumas palavras que apareceram na história.

Após eu contar a história, algumas crianças começaram a me pedir papel sulfite para fazer um chapéu igual ao do Billy. E assim foi feito. Muitas entregaramme um chapéu de presente e, juntamente, uma cartinha carinhosa dizendo que gostavam muito de mim e das histórias que eu contava:

Percebia. novamente, neste encontro a ligação afetiva que se estreitava entre nós por meio das histórias e de nossas discussões. Alguns exemplos de mensagens que as crianças do grupo anterior e as novas crianças me entregaram: (Anexo: p. 232)

- Karen: ' - Tia Selma, eu te amo do meu coração...'

- Leticia Ferreira: '- Tia Selma, eu gosto de você desqueu era o jardim você contava estorinhas muito legais ...Fim..' (desenho/flor)

- Lysa Bastos: 'Para Seuma': (desenho de flor, rato Frederico, porco Waldemar, galo Juvenal - personagens que representavam os amigos inseparáveis das histórias sobre amizade)

- Felipe: 'Para Ceuma: '- Um beijo Felipe' (desenho de casa e árvores)

- Leticia Sarco: ' - Tia Selma. Nem te conheço direito. E eu já gosto da senhora. Tchau. Mil beijocas. Letícia Sarco.'

As crianças pareciam procurar o que de melhor tinham para me oferecer: o seu amor e a sua amizade expressos em seus desenhos, nas mensagens que conseguiam escrever ... Isso tudo foi, e continua sendo, de valor incalculável. Entre mim e as crianças, sentia o tempo todo as histórias permeando e estruturando nossa relação de amizade. Através das discussões desencadeadas pelos diferentes assuntos abordados, iamos nos (re)conhecendo a cada dia com maior profundidade, pois nos desvelávamos e nos entregávamos de forma transparente $e$ direta, como verdadeiros amigos, que discutem, concordam, discordam, mas, acima de tudo se aceitam e crescem juntos.

Pedi, então, para que as crianças me dissessem quais as três coisas que mais haviam gostado na história de Billy brigão e algumas respostas foram:

(Anexo: p. 233)

- Lessandra: navio, bóia, papagaio

- Letícia Sarco: eu gostei da parte que eles ficaram amigo; eu gostei da casa da sereia; eu gostei do chifre do Narval.

- Mateus: navio; Billy brigão, Paulo.

- Alana: ser feliz; fazer um favor; ter carinho.

- Ivã: porque o menino desenho ele; eu gosto do Billy e do paulinho; e da amizade deles.

- Caroline: eles ficaram amigos; Billy era mal vado a gora ésta melhor; eles ficaram felizes.

As crianças pareciam, a cada encontro ampliar suas possibilidades de representação de emoções e valores a partir do assunto que as histórias traziam 
para as nossas discussões. Sempre pediam na saida para que eu voltasse logo e que trouxesse uma história nova e bem legal para elas.

\section{4 de fevereiro de 2000}

Nosso encontro, nesta ocasiāo, foi um pouco diferente dos anteriores. Percebi que à medida que apresentava uma história nova, as crianças mostravamse cada vez mais motivadas e estimuladas. Demonstravam muito interesse pela narrativa e pela escrita desta, fazendo associação com histórias e discussões anteriores Pareciam querer e, com certeza, poder alcançar muito mais na relação ouvir/ (re)criar histórias.

Segundo este retorno das crianças, propus a elas que neste encontro contaria a nova história 'Passarolindo' de uma forma diferente. A narrativa tratava de um pássaro que vivia solitário dentro de um sapato pendurado em um fio de eletricidade no meio da rua. Certo dia, após uma forte chuva, o sapato ficou cheio de água e o pássaro acabou ficando muito resfriado e com febre. Foi, então, que um menino que passava pela rua, resolveu tirar o sapato do fio e descobriu que lá havia alguém doente e precisando de ajuda. Cuidou do Passarolindo e quando este sarou, o menıno jogou de volta o sapato no fio e se foi.

Antes de contar a história, conversamos sobre a importância do trabalho do autor e do ilustrador do livro de história e algumas crianças demonstraram já ter conhecimento sobre as diferenças da atuação de cada profissional em discussão. Muitas crianças disseram que adoravam as histórias e que por isso queriam 'ser autores' para escrever bastante, outras afirmaram que preferiam 'desenhar as histórias': outras. ainda, acabaram decidindo que queriam ser 'autores e ilustradores' ao mesmo tempo, como o autor da história daquele dia.

Combinamos que enquanto contava a história, as crianças iriam imaginar como era o Passarolindo, os lugares e as personagens que apareciam no texto. Propus que quem conseguisse fechar os olhos o fizesse para prestar mais atenção na sua própria imaginação sem se distrair com as outras coisas fora da história. Algumas acharam a idéia bastante desafiadora e conseguiram colocá-la em prática, outras abriam os olhos, de vez em quando, e depois os fechavam novamente...Todas queriam falar sobre os seus pássaros lindos e as criaçōes que fizeram em suas cabeças.

Apesar de imaginar que as crianças iriam corresponder a este desafio de forma positiva, na verdade, elas acabaram surpreendendo-me na devolução de suas criações. Algumas colocações que fizeram sobre a história, mesmo anteş de eu mostrar as ilustrações propostas no livro foram:

Lysa: tia, o meu pássaro é azulzinho...

Karen: o meu é lilás...

Mateus: o meu é vermelho e está voando cada vez mais alto...

Depois as crianças quiseram ver as ilustrações que o autor tinha feito sobre a história e para grande entusiasmo de muitos, as criações do autorl ilustrador coincidiram com algumas criações imaginadas pelas próprias crianças. Senti que 
isto para elas foi muito importante e fez bem para a sua auto-estima, pois se perceberam capazes de criar imagens, de compor a partir de sua própria imaginação

A seguir, as crianças desenharam suas histórias sobre o 'Passarolindo' e deram um nome para ele. Muitas fizeram os desenhos conforme as ilustrações do autor, outras fizeram questão de desenhar suas próprias criações, outras associaram esta história com as anteriores, colocando títulos de textos já apresentados anteriormente, uma aluna (Lysa) colocou o seu nome como editora da obra outras colocaram seus nomes como autores (Júlio, Lessandra, Leticia Sarco, Letícia Ferreira) e Karen decidiu desenhar o que imaginou da história e também o que o autor/ilustrador imaginou para a mesma história. Alana e Caroline, além do desenho. optaram por acrescentar mensagens escritas. (Anexo: pp. 235-6)

A possibilidade de criação das crianças é realmente infinita e extrapola nossas expectativas em relação ao que parecem ser capazes de fazer. Na verdade, a espontaneidade para criar é muito natural e elas descobrem alternativas de produção/criação que, muitas vezes, nem, haviamos pensado ou suposto anteriormente

As crianças continuavam mandando-me bilhetes carinhosos a cada encontro, elogiando as histórias e pedindo mais.

\section{8 de fevereiro de 2000}

Neste encontro, o combinado foi o mesmo do encontro anterior. Enquanto eu lia a história as crianças iam imaginando as personagens e os lugares. Depois da leitura. mostrei às crianças as ilustrações do livro, fizemos as discussões e, como no encontro anterior, muitas crianças mostraram-se bastante satisfeitas ao constatar que o que tinham imaginado era igual ou, pelo menos, parecido com a criação do autor/ ilustrador

A história apresentada foi 'Picote: o menino de papel'. A narrativa tratava de um menino de papel que vivia feliz, cercado de amigos do reino do papel. Certo dia, enquanto Picote olhava um disco voador pela janela, o objeto acabou batendo em um cometa e uma faisca atingiu sua barriga e o menino acabou tendo que ir para o hospital. Mas, logo chegaram os seus fiéis amigos: a cola, a tesoura e outros papéis coloridos para ajudar Picote e ele ficou novinho em folha...

As crianças adoraram a fantasia do mundo de papel e fizeram muitos comentários sobre a amiga tesoura e amiga cola e os outros amigos papéis coloridos que vieram ajudar Picote a sarar depois que ficou queimado na barriga. Começamos a fazer associações com as histórias anteriores e as crianças comentavam que era muito bom ter amigos para ajudar sempre...

Aproveitando o entusiasmo das crianças com a história do dia e a relação com as histórias anteriores, pedi para que elas respondessem algumas questões sobre as histórias que já haviam ouvido ou lido e o que achavam sobre tudo isso.

Inspirei-me, para tal, na máxima de Charles Dickens que ressalta o valor das histórias infantis na formação da criança:

' Chapeuzinho Vermelho foi meu primeiro amor.

Se pudesse ter casado com ela, teria conhecido a perfeita bem-aventurança. 
Considerando-se que a maioria das crianças já estava alfabetizada, ou pelo menos na trajetória de construção do processo da leitura e escrita, procurou-se apresentar, literalmente, as respostas que elas próprias escreveram; transcrevendose, portanto, a grafia das mesmas.

Alguns exemplos das questōes propostas às crianças e algumas respostas dadas foram

\section{1-Você gosta de ouvir e ler histórias? Por quê?}

Caroline: Eu gosto de ler histórias porque é legal.

Alana: Eu gosto de ler e ouvir as histórias no meu computador porque é legal.

Leticia Ferreira: Eu gosto de ouvir e ler histórias porque é legal e bonito.

Leticia Sarco: Gosto porque eu aprendo muita coisa.

Eduardo: Sim Porque são aventureiros e legais.

Felipe. Eu gosto muito porque é legal.

Talita Brasil: Por que eu axo divertido

Mateus: Sim porquê eu aprendo

\section{2-Alguém costuma contar histórias para você em casa?}

Alana: Eu. (Explica que ela lê para si mesma)

Lessandra: Não

Karen: Conta asveses minha mãe Márcia.

Ivã: Ninguém

Vitor: Vó mãe e pai

Thalita Carli: Não.

Lysa: Meu pai.

Jessica: Papai.

3- Você lembra de professoras que contaram histórias para você desde que entrou na escola? Se lembra, escreva o nome delas. 
Alana: Sim. Tia Selma, tia Renata, tia Viviane, tia Renata

Leticia Ferreira: Tia Leide Tia Patrisia Tia Fabiana.

Luana: Tia Dione, tia Fafiana, tia patricia

Eduardo: Viviane, Selma, Daniela, Renata.

Karen: Tia Viviane tia Renata tia Selma

Ivã: Tia Viviane. Tia Selma

Thalita Carli: Tia Viviane Tia Fabiana Tia Ceila Tia Dione tia Renata Tia Selma.

Julio: Eu mesmo conto.

\section{4-Escreva o nome de algumas histórias que você mais gostou de ouvir.}

Lessandra: Simderela

Luana: Alice nos paises da maravilhas Precicinha perigosa Palhacinho.

Leticia Sarco: É hora é hora

Eduardo: Bili-Brigão, Festa no céu, A de amigo, Passaro lindo, Os aventureiros.

Murilo: Picote $O$ pequeno dragão.

Mateus: A cor. Festa no céu.

Vitor: Picote

Julio: Billy Brigão e o picote e Os aventureiros etc..

5- Você gostou das histórias que a professora Selma contou na classe? Por quê?

Caroline: Billy porque ele ficou amigo do paulinho.

Alana: Sim.Porque muitas pessoas ajudando.

Leticia Ferreira: Sim. Porque amizade é boa.

Eduardo: Sim. Porque ela conta com amor e carinho e muita felisidade.

Karen: Mostram porque é para a gente entender melhor a amizade.. 
Talita Brasil: Os aventureiros eram amigos, por que o Billy Brigão sico bosinho.

Mateus: Porquê falafa de amizade e respeito.

Thalita Carli: Por que todo mundo fica amigo

\section{6-Para você, o que é ser amigo?}

Caroline: Ajuda cada um

Alana: Respeito dividir as coisas

Leticia Sarco: É legal ter amizade com as pessoas.

Eduardo: Gostar como se fosse um filho e irmão

Talita Brasil: E respeita o outro e tem compriemção ou outro e muca briga.

Murilo: E uma pessoa que costa da gente.

Mateus: Amisade é divertida.

Thalita Carli: Fazer amizada cemtajumto.

7-Desenhe o seu amigo, ou sua amiga, ou todos os seus amigos, coloque o nome deles e escreva algo que gostaria de dizer para eles. (Anexo:pp.238-240)

Caroline: 'Carol... Karen... Você é muito legal.'

Alana: 'Eu gosto de você primo Rafael.'

Lessandra: 'Etisia...Selma...Daniela.'

Leticia Ferreira: 'Eles são meus melhores amigos.'

Luana: 'Que eu adoro eles.'

Leticia Sarco: 'Adoro vocês são os melhores amigos principalmente a Maysa e a Thalita.'

Eduardo: 'Ivã...Leticia F. O Ivã elegau ele da muito amor e carinho e felisidade.'

Felipe: 'Alana...Julio...eu gosto muito de voceis.'

Karen: 'Thalita... Leticia F... Tia Selma...Joyce $4^{a}$ B... Tia Daniela... Eduardo.' 


\section{9 de fevereiro de 2000}

Neste encontro, após ter lido, ouvido e compartilhado discussões com as crianças sobre histórias relacionadas ao valor humano 'amizade', conforme havia suscitado o interesse do grupo, pretendia concluir esta etapa da retomada da pesquisa, através de um registro da produção das crianças em seus próprios livros de histórias.

Conversei com as crianças explicando se, depois de ouvirem e contarem estórias sobre amigos, gostariam de criar suas próprias histórias. A motivação foi geral. O enredo, a capa, as ilustrações ficariam a critério de cada um com sua imaginação e criatividade, sendo que a possibilidade de serem autores e ilustradores, ao mesmo tempo, deixou todas as crianças muito entusiasmadas.

As produções foram bastante variadas e os temas escolhidos pelas próprias crianças referiram-se a: (Anexo: pp. 242-3)

- aspectos relacionados à influência cultural de outros paises, como os Estados Unidos e o Japão. na febre do modismo dos Pokémon (em inglês Pocket monsters - monstros de bolso).

Segundo informações apresentadas pela Revista Nova Escola de Março de 2000 (pp. 18-23), os Pokémon são originários do Japão. Chegaram aos Estados Unidos em setembro de 1998 e, conseqüentemente, ao Brasil, em maio de 1999, apresentados por desenhos animados transmitidos pela Rede Record de televisão. Os monstrinhos foram criados por Satoshi Tajiri, um japonês de 34 anos, que na infância gostava de colecionar insetos e na adolescência apaixonouse por videogames. Atualmente, em torno de 151, com perspectiva de aumentarem o número de personagens até 2003, os monstrinhos Pokémon conquistaram o público infantil, talvez pelo segredo que os torna muito cativantes na estrutura do jogo que apresentam com o desafio de capturarem mais e mais monstrinhos com o lema: 'Temos que pegar', como se apresentassem a grande força da socjalização, buscando mais companheiros para o grupo. Apesar de algumas críticas de especialistas e educadores às lutas que aparecem nos desenhos, atraindo as crianças, talvez pela associação que vivem na resolução de seus conflitos internos, os Pokémon aparecem na TV, em figurinhas, revistas, chaveiros, mochilas e até na produção de histórias pelas crianças que os remetem à idéia de amizade como pude verificar na elaboração dos livros que combinamos fazer - seis crianças (Mateus, Alana, Felipe, Murilo, Thalita Carli, Julio) optaram por descrever histórias sobre os Pokémon demonstrando conhecer detalhadamente as personagens e os locais de ação de suas histórias, sempre enfacando os pequenos monstrinhos como amigos.

- aspectos de produção relacionados à preocupação com a questão ortográfica - o desafio da escrita. Muitas crianças vieram me perguntar sobre a grafia de algumas palavras, pois queriam escrever 'certo' suas histórias sobre os amigos. Embora sempre tivesse reforçado suas possibilidades de criação, aceitando o ritmo de cada criança, percebi que muitas precisavam de um estimulo extra para o seu trabalho e que esperavam de mim esta mediação. Assim, a pedido das crianças, que se mostravam ansiosas e preocupadas com esta situaçāo, escrevi na lousa algumas palavras como Pokémon, revolta dos bichos, triste, 
dragãozinho, entre outras. Na verdade, parecia que o que queriam era mesmo uma confirmação, pois muitas já haviam escrito as palavras solicitadas em suas histórias e diziam, após confrontarem-nas com as da lousa, 'que tinham acertado'. Sabia que a questão do erro e do acerto deveria ser discussão a ser aprofundada pela classe, embora jả tivéssemos discutido isso em outras ocasiões, ressaltando que o mais importante era que escrevessem como conseguiam e que depois, aos poucos, iríamos descobrindo outras possibilidades de escrita que se aproximasse ao jeito que é escrito nos livros, nas revistas, nos cartazes etc...Percebi, no entanto, pela ansiedade das crianças em registrarem as suas histórias, que aquele não seria o momento oportuno para retomar tal discussão.

- aspectos relacionados ao gênero e estilo literário. Algumas crianças demonstraram preferir escrever em prosa, detalhando suas histórias com exemplos e minúcias. Outras pareciam apreciar os indícios do estilo poético, colocando versos às vezes rimados, no meio de suas narrativas. Uma preferência que aparece bastante, neste sentido, talvez ligada às idéias sintéticas e mais objetivas, é a escrita em quadrinhos, que muitas crianças optaram por apresentar em suas histórias, como ocorre na escrita dos gibis, que elas tanto apreciam.

De modo geral, as obras das crianças foram riquissimas. Percebi que conseguiram fazer uma rede de associações com histórias antigas e histórias mais recentes que haviam ouvido sobre amigos, criando, a partir desse conjunto de informações e vivências cumulativas as suas próprias histórias, acrescentando características múltiplas de momentos que estavam vivenciando em seu desenvolvimento afetivo-cognitivo, demonstrando 0 interesse pelos valores humanos para uma saudável e positiva convivência do grupo e, também, pelo desafio com a escrita, já que no inicio desta retomada de nossos encontros muitas já estavam alfabetizadas e outras ainda demonstravam insegurança na construção do processo da leitura e escrita. Considerando-se que o reinício de nossos encontros deu-se em fevereiro de 2000, a maioria das crianças acabavam de chegar da $1^{a}$ série e, portanto, o desafio da escrita e da leitura, de modo geral, era considerável para todas - algumas mostravam-se mais inseguras, outras precisando de um pouco mais de estímulo e reforço, mas todo o grupo parecia ansioso pela mediação do professor como auxiliar diante do processo de construção da leitura e escrita

\title{
Reflexões ao encerrar as sessões de retomada do projeto
}

\author{
'É preciso ver o mundo \\ com os olhos de uma criança.' \\ Henri Matisse
}

As respostas e colocações das crianças deixam claro o seu interesse pela literatura. As crianças são capazes de lembrar as professoras ou as pessoas que 
Ihes contaram histórias, demonstrando que registraram em suas memórias o que ficou de mais significativo na trajetória de suas próprias histórias de vida.

Algumas crianças relataram que ninguém contava histórias para elas em casa; portanto, parece que, neste sentido, embora saibamos que a escola não deve ser considerada como 'redentora', nem tampouco responsabilizada por todas as mazelas sociais, precisamos recorrer a um consistente trabalho de incentivo à leitura e escrita das crianças, pois a maioria não possui pais que possam auxiliá-las neste particular - por desconhecerem a importância do processo, ou por não conhecerem e por não dominarem o próprio processo (pais analfabetos ou semianalfabetos). ou por não terem tempo, ou mesmo pela falta de interesse ou iniciativa, considerando que só à escola cabe este papel de estimulação à função social da lingua oral e escrita

Considerando-se a criança como única, mas que, ao mesmo tempo, experiencia um papel de dupla vivência - na familia e na escola - precisamos, então, buscar concomitantemente a estimulação à criança e também à familia, no sentido de que os pais sejam alertados para a importância do incentivo que podem oferecer, dentro de suas possibilidades, a seus filhos.

A criança que é valorizada e estimulada em suas produções torna-se mais confiante e capaz de se desenvolver, plenamente, em múltiplas situações de aprendizagem

Em seus desenhos e nas mensagens que deixam a seus amigos, as crianças demonstram o valor que dão à amizade. Muitas envolvem também as professoras como amigas e destacam a palavra PAZ escrita em suas roupas. Elas captam, armazenam e devolvem vivências de forma surpreendente e criativa, formando redes de associações o tempo inteiro e nos deixando cada vez mais admirados com suas possibilidades de criação - quanto mais estímulos são oferecidos. maior é a resposta das crianças, ultrapassando sempre nossas iniciais expectativas

Esta deve ser a nossa mola propulsora como educadores - incentivo, a motivação e o estímulo - , pois percebemos que a nossa mediaçāo pode auxiliar as crianças a se desenvolverem sempre e mais, explorando todas as alternativas de aprendizagem, por meio de suas múltiplas linguagens como forma expressão.

Nesse particular, a literatura assume seu papel de incontestável valor e auxilia o educador na situação do processo ensino-aprendizagem da leitura e escrita, como elemento desencadeador de todas as áreas do saber, já que oferece infinitas possibilidades de vivências às crianças.

O processo de alfabetização aparece como um momento desafiador à criança, que demonstra, neste momento significativo de seu desenvolvimento, uma enorme vontade de ler e compreender, poder escrever o que pensa e deseja transmitir sobre as histórias que ouviu ou que intenciona criar. Sendo assim, este processo é aliado inseparável da literatura, pois amplia as possibilidades de apreensāo e aproprią̧ão do mundo da leitura e da escrita pela criança.

Através da abordagem teórico-prática deste trabalho, foi reforçada a constatação inicial da proposta da pesquisa, demonstrando que as histórias, tão amadas e desejadas pelas crianças, sāo capazes de torná-las mais receptivas, atentas e seguras na construção e elaboração de valores e experiências de suas próprias vidas. 


\section{Considerações finais}

A literatura amplia e enriquece a nossa visão da realidade de um modo especifico. Permite ao leitor a vivência intensa e ao mesmo tempo a contemplação critica das condiçōes e possibilidades da existência humana A literatura é olugar privilegiado em que a experiência vivida e a contemplação critica coincidem num conhecimento singular, cujo critério näo é exatamente a verdade e sim a validade de uma interpretação profunda da realidade tornada em experiência. Na fruição da obra de arte literária podemos assimilar tal interpretação com prazer (vivendo-a e contemplando-a criticamente), mesmo no caso de ela, no campo da vida real, se nos afigurar avessa às nossas conviç̧ões e tendências. '

Anatol Rosenfeld

No processo de elaboração desta dissertação nosso objetivo maior foi o de ressaltar e resgatar a importância primeira da literatura na educação como elemento-chave para a reflexão de professores/educadores e alunos/educandos no caminho da construção e vivência de valores humanos.

Por intermédio da literatura, sem que esta se constituisse, em momento algum, como pretexto, nosso desafio maior foi tentar demonstrar como o registro secular das histórias pode auxiliar na (re)significação de valores que perscrutaram as histórias de vida de professores/educadores através de suas memórias de infância e de sua aprendizagem ao longo da vida, favorecendo diretamente sua reflexão como docentes atuantes no processo de ensino-aprendizagem direcionado, agora, a seus próprios alunos

Os resultados obtidos nesta pesquisa levam-nos à constatação de que a literatura, antes de mais nada, é registro de vida, seja ele oral ou escrito. Pois os fatos vivenciados pela humanidade no decorrer da história vieram de contos, de lendas, de relatos, muitas vezes transmitidos, verbalmente, de geração à geração, por meio de pessoas iletradas que, mesmo sem possuírem o suporte da língua escrita, possuiram e possuem, certamente, sua literatura e sua cultura.

A importância da literatura alia-se, portanto, a uma questão temporal, de forma que passado, presente e futuro inter-relacionam-se na reconstrução de fatos já vivenciados, e, a partir destes, na construção significativa dos fatos presentes e, ainda, na elaboração antecipada inclusive de fatos futuros, com base nas experiências vivenciadas pelos fatos anteriormente mencionados.

Esta teia temporal de experiências proporcionadas pela literatura auxiliam diretamente no encaminhamento das questões educacionais, pois sabemos que a valorização docente está presente nas mais diversas obras de reflexão a partir de histórias com mensagens explicitas, ou até mesmo subliminares, que enaltecem a função de inquestionável valor do professor/educador através da história, como foi ilustrado neste trabalho por autores, pesquisadores e grandes contribuidores para a 
educação como Rubem Alves, Célestin Freinet, Paulo Freire, Madalena Freire e Antonio Nóvoa, entre outros.

A literatura permite que nos façamos perceber e ser no mundo tomando como ponto de referência as vivências daqueles que nos antecederam na história e, ainda, aguçam nossa criatividade para que possamos nos projetar à posteridade. $O$ mais interessante de tudo isso é que ela é capaz de desencadear beneficios a educadores. educandos, familiares, enfim, ela é fonte ramificadora de múltiplas possibilidades de aprendizagem vista de forma coletiva, pois todos podem dela usufruir e. conseqüentemente, evoluir, refletir e crescer.

Dessa forma, partindo da premissa de uma importância universalizante e abrangente da literatura, alguns pontos merecem ser revisitados nas considerações finais sobre este trabalho.

$O$ primeiro deles refere-se à questão de que não existem receitas prontas para a consecução de obras literárias ou discussão sobre as mesmas, já que a natureza literária de um texto é instaurada através da relação que as palavras estabelecem com o contexto, com a situação de produção e leitura, ou seja, a literatura está intimamente ligada ao contexto sócio-histórico, podendo conferir-lhe diferentes significados de acordo com os momentos vivenciados; surge aí, sua estreita relação com os valores humanos que também possuem uma especificjdade de significações relacionadas ao contexto onde se inserem. Na verdade, seja oral ou escrita, tratando-se das histórias da história da humanidade, todo e qualquer registro, no sentido de preservação das vidas dos povos, por intermédio da memória - capaz de reavivar fatos por meio da oralidade ou da escrita - , é, portanto, literatura.

Um segundo fator merecedor de argumentação diz respeito à questão da literatura vista de maneira geral que não se desvincula ou fragmenta de uma literatura especifica considerada tipicamente infantil. Sob este aspecto, ao invés de se limitar à literatura infantil tudo o que para a criança se escreve, esta discussão deve ser antes aprofundada ressaltando como nos lembra MEIRELES (1984) que não existe uma literatura infantil a priori, mas a posteriori, pois quem vai designar se o texto como tal é a própria criança, de acordo com o que lê com utilidade e prazer.

Nesse sentido, surge um terceiro fator que merece ser enfatizado em nossas considerações, pois está intimamente relacionado à formação do professorleducador como leitor maduro e consciente de seu papel na escolha de obras literárias que possam oferecer a literatura à criança como forma de prazer, auxiliando-a a se tornar uma pessoa mais crítica, criativa e consciente. O professor/educador maduro que demonstra paixão pela leitura, com sua postura de leitor apaixonado pela literatura, acaba seduzindo e motivando os seus alunos/educandos pelas obras literárias. Podemos deduzir, então, que quanto mais lemos, mais formamos pontes de significação de textos atuais com os anteriores, muitas vezes, alterando significados e valores já existentes em nossa concepção de vida, causando desequilibrio e nos reestruturando para próximas leituras, e, por conseguinte, para próximos desequilibrios e novos reequilibrios, em um círculo vicioso e prazeroso de aprendizagens cumulativas propiciadas pela literatura. $\mathrm{Na}$ verdade, os textos acoplados, que se seguem cumulativamente na trajetória do professor/educador, são capazes de (re)significar os valores e o sentido da vida, influenciando, por decorrência, sua prática pedagógica junto aos alunos/educandos. 
Outro fator indispensável a ser aqui colocado, no sentido de se formar leitores apaixonados pela literatura, reporta-se à importância de se oferecer à criança, desde cedo, o contato com o mundo da literatura, pois conforme reitera LAJOLO (1982), esta aproximação pode começar a nascer ou morrer a partir dos sete anos, da alfabetização, nos primeiros contatos com o texto...Tudo depois, por conseguinte, será reforço ou terapia sobre bases já estruturadas anteriormente. Na verdade, o fato de se oportunizar a vivência da literatura, desde cedo, dá à criança a possibilidade de se entregar à leitura, refletir sobre ela, incorporá-la ou se rebelar, questionando-a e propondo outras novas leituras ainda não previstas. Esse processo de construção com base na reflexão e na relação dialógica do autor com o leitor é que confere, aos poucos, em um processo de sedução, a paixão deste pela literatura -- mesmo que, muitas vezes, como resultado de uma luta simbólica a partir de um confronto de idéias com aquele - , pois começa a se sentir coparticipante na elaboração de novas histórias, ou, até mesmo, na reelaboraçāo daquelas já abordadas por outros autores. O que se deve oferecer à criança é o vivenciar a função social da leitura, pois através de uma gama ampla de textos, mesmo antes do processo de alfabetização de maneira sistematizada - dai o indiscutivel valor da Educação Infantil - , a criança já está construindo pontes de significação para sua vida e a literatura pode auxiliá-la, sobremaneira, em sua descoberta e estruturação de mundo. Afinal, literatura é arte, é expressão estética, é movimerito e magia e a partir dela a criança experiencia a sua grande aventura de viver

Os fatores até aqui expostos buscam reiterar que é possível implementar a literatura como uma proposta pedagógica abrangente - desde a Educação Infantil_, capaz de desenvolver um Programa de Educação em Valores Humanos que beneficie professores/educadores, alunos/educandos, funcionários, equipe técnica e familiares, por meio da reflexão, da troca de experiências e da vivência de valores que permeiam a vida de todos os envolvidos, direta ou indiretamente, no contexto escolar, na resolução e possiveis encaminhamentos de situaçōes de conflito que podem ocorrer dentro e fora da escola.

O projeto 'Literatura Infantil: uma viagem de transformação através de Valores Humanos' apresentado no decorrer desta dissertação como pesquisa de campo, fundamentou-se, especialmente, na crença de que é possivel oferecer à criança, desde a Educação Infantil, o contato com a literatura, aproveitando a grande riqueza desta experiência continua e sem fim, na construção entre parceiros inseparáveis que precisam atuar acreditando, realmente, no processo: professor/educador e aluno/educando - juntos precisam buscar o significado dos valores humanos, da ética e das regras necessárias ao convivio social. Os depoimentos dos participantes, envolvidos no referido projeto, demonstram, como retorno, a sensação de contentamento e de um bem-estar maior nas relaçōes compartilhadas, por decorrência de sua implementação na escola.

Se pensamos a literatura como eixo desencadeador de reflexão para a vida, deduzimos, assim, que as escolas precisam incentivar e propiciar a sua experienciação desde a mais tenra idade da criança, já que conhecemos a importância incontestável da Educação Infantil e o significado incomparável dos primeiros anos de vida para a estruturação de sua personalidade, assim como para a vivência de experiências marcantes, indispensáveis à sua formação moral, ao seu convivio com o outro, ao aprimoramento das relaçōes intra e interpessoais. 
O caminho inicial parece, portanto, pautar-se no investimento direcionado à Educação Infantil, pois apesar de alguns avanços em sua valorização, ainda permanece, para muitos, como um nivel de ensino que não apresenta valor em si mesmo, servindo somente como suporte ou elemento de preparação para niveis educacionais subseqüentes

É claro que, se bem estruturada, a Educação Infantil acabará favorecendo outros niveis de ensino que virão subseqüentemente; no entanto, não é sua tarẹfa básica preocupar-se com momentos posteriores, mas sim com o momento rico da criança em formação, que tem por direito vivenciar todas as suas possibilidades de aprendizagem em seu próprio ritmo e circunstâncias da construção de seu conhecimento.

Perceber a importância da Educação Infantil leva-nos, também, à constatação que, paralelamente ao trabalho desenvolvido na escola, isto exige também uma politica governamental pautada no reconhecimento destas questões, aplicando investimentos para o aprimoramento deste nivel de ensino de inigualável importância, já que representa a base do desenvolvimento integral do ser em formação na mais plena abrangência.

Considerando o valor da Educação Infantil e o da literatura na formação do ser. percebemos que estes dois aspectos de nossa discussão precisam ser refletidos e viabilizados desde os primeiros anos de vida da criança.

É na escola de Educação Infantil que a criança fará o seu contato inicial com o mundo da literatura, caso isto ainda não lhe tenha sido oportunizado no meio familiar, ou, ainda, no caso de a familia já lhe haver conferido a oportunidade de vivenciar a função social da leitura e da escrita, poderá estreitar, gradativamente, seus vinculos com as vastas histórias pertencentes ao universo sedutor e apaixonante das letras

As questões relacionadas à ética e à estética podem ser caracterizadas como inerentes à literatura e ambas são fatores de extrema atração à criança por considerar sua grande ânsia pela descoberta do mundo e, ainda, pela vivência de seus valores em formação que permeiam as considerações sobre as regras, os limites, enfim, os critérios para o convivio social.

A literatura pode ser vista, assim, como o portal condutor à experimentação da vida pela criança, por meio das personagens das histórias, nas mais diferentes situações vivenciadas.

A partir de diferentes e inúmeras vivências oferecidas pela literatura, a criança poderá refletir sobre sua ação no mundo, percebendo que é agente decisivo no encaminhamento de suas atitudes, que poderá colaborar, ou não, para o bem geral da humanidade.

Para finalizar este trabalho, gostariamos de fazer, ainda, algumas considerações de caráter geral a seu respeito, já que estas encontram-se, estreitamente relacionadas aos caminhos que podem favorecer, ou não, a implementação da literatura nas escolas, com base em uma proposta pedagógica séria, consistente e compromissada com a reflexão e vivência dos valores humanos do professorleducador e do aluno/ educando. 
Na trajetória da formação da criança, a literatura constitui-se como carrochefe na discussão sobre os valores ou antivalores apresentados em diversas histórias percebendo, refletindo, assinalando dúvidas, defendendo pontos de vista, criticando, enfim, elaborando sua própria estrutura moral.

Sob este ponto de vista da formação moral, PUIG (1998b), dá-nos uma importante contribuição defendendo a idéia de que os valores humanos são construidos, ou seja, a educação moral é essencialmente um processo de construção de si mesmo. Não se trata de algo imposto de fora para dentro, mas de uma tarefa de dar forma moral à própria identidade, através de um processo de reflexão-ação a partir das experiências que cada um vai vivenciando no dia-a-dia.

Nesse sentido, voltamos novamente à importância da escola no oferecimento de vivências significativas que podem ser dadas à criança para que reflita e elabore seus valores, estruturando sua própria formaçāo moral, pois sabemos, sem sombra de dúvida, que a familia - considerada como instituição primária de socialização da criança - cada vez mais, está mostrando-se impotente, ou talvez até incapaz, de conferir experiências valorativas à criança, tendo em vista sua própria dificuldade de se estruturar, delegando à escola considerada como instituição secundária de socialização da criança - , muitas das atribuições que seriam da competência do meio familiar

O que nos parece óbvio é uma forte tendência à inversão ou por que não dizermos acúmulo de atribuiçōes conferidas à escola, que, aos poucos,. está assumindo o papel das instâncias primária e secundária de socialização infantil. É preciso continuarmos, mas, ao mesmo tempo, estarmos alertas para que esta sobrecarga de atribuições não se torne lugar comum, mostrando ser natural a escola assumir e se responsabilizar por questões que fogem aos parâmetros educacionais, absorvendo todas as mazelas sociais que se refietem no contexto escolar e tendo, ainda. que responder por isto

Trata-se não de uma visão pessimista da questão educacional, mas de um posicionamento crítico-reflexivo que, ao mesmo tempo, acredita no que é possivel, oferecendo-se para refletir e se mobilizar na busca de melhores caminhos. para garantir o cumprimento de sua atuação. Digamos que é preciso ter o bom senso, não assumindo uma postura totalmente ingênua, acreditando que a escola tudo pode resolver, e, nem tampouco, achar que tudo está perdido, deixando de acreditar que precisamos continuar, com e apesar das dificuldades, sem cairmos no comodismo e na falta de esperança.

Retomando nossas considerações sobre a relação entre literatura e valores humanos, é importante tecermos alguns comentários sobre La Taille (1999) quando revela sua preocupação em relação às questões abordadas em nossa discussão, confessando sua grande preocupação ao perceber que uma visão reducionista sobre o desenvolvimento moral pode considerar indevidamente que trabalhar a moral com as novas geraçōes já é suficiente para controlar a violência, a injustiça, a pobreza, a humilhação, acreditando que as transformações pessoais, .pgr si mesmas, conseguirão resolver todas as dificuldades sociais.

As transformações pessoais são importantes, mas, por si só, não se bastam, faz-se necessário também transformaçōes sociais, e, ainda, é 
indispensável ter claro que as preocupações éticas não podem se dar em detrimento das preocupaçōes políticas.

A questão de uma vontade política que valorize e invista nas situações educacionais são inerentes e indispensáveis ao processo de reflexão e melhoria da qualidade de ensino que desejamos oferecer a nossos alunos/educandos.

É preciso que façamos claras considerações sobre a concepção de criança que temos em mente e que tipo de criança, ou melhor, futuro adulto, queremos formar e, para tal, que tipo de educação podemos oferecer-lhe

Precisamos pensar na escola que temos, hoje, como nossa realidade, quais pontos podemos melhorar, que currículo consistente e compromissado com as questões éticas e com o desenvolvimento moral e integral da criança estamos construindo. como estamos atuando qualitativamente como professores/educadores na mediação da construção do conhecimento de nossos alunos/educandos, e, especialmente, como ponto-chave de nosso trabalho, quando, como e em que momentos oferecemos à criança a oportunidade de vivenciar a literatura na escola, buscando, através da reflexāo, a implementação de um verdadeiro Programa de Educação em Valores Humanos, capaz de auxiliar no encaminhamento do processo de ensino-aprendizagem por meio do aprimoramento das relaçōes intra e interpessoais

Pesquisas feitas em relação ao desenvolvimento da moral revelam a importância das regras, dos limites e da vivência de valores humanos para a constituição da personalidade, dai a preocupação em apresentar nesta discussão possiveis caminhos que possam auxiliar a escola a propiciar múltiplas alternativas de reflexão à criança para que ela mesma estruture sua personalidade moral, tornando-se participativa, atuante e realmente comprometida com o respeito a si mesma e aos outros, na experimentação mais ampla e abrangente do verdadeiro sentido da cidadania.

Sabemos que a escola não deve ser considerada como redentora da humanidade e que precisa de ajuda em relação às transformações sociais que acabam despejando-Ihe dificuldades que não são diretamente de sua alçada, mas sabemos, também, que muitas conquistas já foram e vêm sendo realizadas apesar da complexidade da atual situação do sistema educacional. Dai considerarmos oportunas as discussões de âmbito político-social aqui abordadas, uma vez que a literatura, de modo geral, permeia todas estas questões, influenciando-as, no que se refere ao registro de decisōes governamentais fundantes na transformação da história da humanidade e, ao mesmo tempo, delas também recebendo influências, direta ou indiretamente, no que se refere à sua valorização e real implementação no contexto socioeducativo.

Nossa meta maior parece ser continuar captando possibilidades, reivindicando, chamando e tentando seduzir a familia ou representantes dela para nos auxiliar no processo, aprimorando, repensando e reavaliando nossa postura de educadores, a cada dia, enfim, se conseguirmos inquietaçōes deste tipo em nossa trajetória, acreditamos estar no caminho certo, ou pelo mesmo na busca daquilo que realmente pensamos ser melhor para a educação... para nossos alunos/educandos.

O que podemos apreender de tudo isto é que a contribuição de cada pesquisador e educador sobre as questōes relacionadas à importância da literatura 
na educação e, mais especialmente, de sua importância na formação de caminhos para uma Educação em Valores Humanos, mostrou-nos, por intermédio desta pesquisa, a viabilidade desta explanação, auxiliando-nos a buscar novas reflexões na formulação e estruturação de propostas educacionais relacionadas a este tema. É preciso captarmos todas as possibilidades oferecidas: filtrá-las de acordo com nossa própria realidade, contextualizando-as e, assim, buscar proporcionar à criança em formação elementos que a orientem melhor, aprimorando, cada vez mais, suas potencialidades de forma integral.

Somos e seremos eternos pesquisadores/educadores à procura de novos e mais promissores caminhos e, ai, repousa a causa maior da educação: o seu carảter de dinamismo e infinita transformação. A literatura assinala um caminho importante neste sentido, pois guarda em sua essência maior a história e sabedoria de vida da humanidade conferindo-nos experiências inéditas, muitas vezes, por nós, jamais vivenciadas, oportunizando-nos, portanto, a apropriação do sentido verdadeiro do que é aprender e ensinar com base no compartilhar.

Precisamos acompanhar a trajetória da história da humanidade, adaptarmonos a muitas mudanças, mas, ao mesmo tempo, não podemos perder o eixo dos aspectos 'universalizantes' da vida, que tanto contribuem para a formação moral do ser, por meio das regras sociais, da ética e dos valores que, nós, como educadores, precisamos trabalhar com as crianças, desde sempre...lembrando a indispensável participação da literatura como norteadora de todo este processo.

Esta é. com certeza, uma discussão que não se encerra e nem se esgota aqui, mas que ela possa, de alguma forma, ter contribuido para alimentar nossas inquietações, já que na humildade da busca tornamo-nos mais fortes, confiantes e persistentes na caminhada, pois sabemos que compartilhamos ideais educacionais em comum e, acima de tudo, que não estamos sozinhos neste caminhar. 


\section{Bibliografia}

ACHARD, P. et al. Papel da memória. São Paulo: Pontes, 1999.

ALVES. R.A. Conversas com quem gosta de ensinar. São Paulo: Cortez, 1985.

Estórias de quem gosta de ensinar. São Paulo: Cortez, 1989.

Entre a ciência e a sapiência: o dilema da educação. São Paulo: Loyola,

1999

AMARILHA. M Estão mortas as fadas? Literatura infantil e prática pedagógica. Rio de Janeiro: Vozes. 1997

ANDRADE, T de. Saudade. São Paulo: Companhia Editora Nacional, 1954.

ARIÉS, P História social da criança e da familia. Rio de Janeiro: LTC, 1981.

BANDEIRA, P. A formiga e a pomba. Sāo Paulo: Moderna, 1997.

BARRO, J. de A formiguinha e a neve. São Paulo: Moderna, 1995. Chapeuzinho Vermelho. Sāo Paulo: Moderna, 1995.

BARTHES, R. O prazer do texto. São Paulo: Perspectiva, 1996.

BENNETT, W. J. O livro das virtudes para crianças. Rio de Janeiro: Nova Fronteira. 1995.

BETTELHEIM, B. A psicanálise dos contos de fadas. Rio de Janeiro: Paz e Terra, 1980.

BORGES, T. M. M.: A criança em idade pré-escolar. São Paulo: Ática, 1994.

BRANDÃO, C. R. O que é educação. São Paulo: Brasiliense, 1981. 
BRASIL, Secretaria do Ensino Fundamental. Parâmetros Curriculares Nacionais (ensino de primeira à quarta série): convivio social e ética / orientação sexual. Brasilia: MEC/SEF. Versão agosto/1996.

BRASIL, Secretaria de Educação Fundamental. Parâmetros Curriculares Nacionais (ensino de primeira à quarta série) : Apresentação dos Temas Transversais e Ética. Brasilia: MEC/SEF, 1997.

BRASIL, Secretaria de Educação Fundamental. Parâmetros Curriculares Nacionais (terceiro e quarto ciclos do ensino fundamental) : introdução aos parâmetros curriculares nacionais. Brasilia: MEC/SEF, 1998

BRASIL, Secretaria de Educação Fundamental. Referencial Curricular Nacional para a Educação Infantil. Brasilia: MEC/SEF, 1998.

BRASILIA Lei de Diretrizes e Bases da Educação Nacional - LDB . Lei no 9394 de 20 de dezembro de 1996. MEC/ Brasília, 1996

BRUNER, J. Atos de significação. Porto alegre: Artes Médicas. 1990.

1978

BUARQUE, C. Chapeuzinho amarelo. Rio de Janeiro: Livraria José Olympio, 1997.

CADERNOS CEDES. N ${ }^{0}$ 14. Recuperando a alegria de ler e escrever. São Paulo: Cortez, 1987.

CALVINO, I. Seis propostas para o próximo milênio. São Paulo: Companhia das Letras, 1990.

CANDAU, V.M. et al. Tecendo a cidadania: oficinas pedagógicas de direitos humanos. Petrópolis, R.J: Vozes, 1995.

CASCUDO, C. Contos tradicionais do Brasil. Rio de Janeiro: Ediouro, 1998.

CHURCH, A. A arte da vida. Gente: São Paulo, 1993. 
COELHO, N. N. Literatura infantil: teoria-análise-didática. São Paulo: Ática, 1993.

. Panorama histórico da literatura infantil / juvenil. São Paulo: Ática,1991.

Edusp, 1995

Dicionário crítico da literatura infantil juvenil brasileira. São Paulo,

COLASANTI. M. O lobo e o carneiro no sonho da menina. Rio de Janeiro: Ediouro, 1998

CRAXI. A Os valores humanos: uma viagem do "eu" ao "nós". São Paulo: Meca, 1995

CUNHA. M. A. A. Como ensinar literatura infantil. Belo Horizonte: Bernardo Álvares, 1970

Literatura infantil: teoria e prática. São Paulo: Ática, 1995.

DANTAS, H. OLIVEIRA, M. \& LA TAILLE, Y. Piaget, Vygotsky e Wallon. São Paulo: Cortez, 1992.

DIAS, M.C.M. Saberes essenciais ao educador da primeira infância: uma reflexão na perspectiva de seus protagonistas. Tese (Doutorado em Educação) - Faculdade de Educação, Universidade de São Paulo, 1997.

DIEUZEIDE, H. Antes dos seis anos. Em um decênio haverá no mundo 900 milhões de crianças em idade pré-escolar. In: O Correio. Rio de Janeiro, UNESCO/FGV, 1978

DINORAH, M. L. P. O livro infantil e a formação do leitor. Rio de Janeiro: Vazes, 1995.

DISKIN, L. et al. Ética, valores humanos e transformação. São Paulo: Fundação Peirópolis, 1998.

DUSKA, R. e WHELAN, M. O desenvolvimento moral da idade evolutiva: um guia de Piaget e Kohlberg. São Paulo: Loyola, 1994. 
DREW, N. A paz também se aprende. São Paulo: Gaia, 1990.

FERRÁNDIZ, J. A esquilinha caprichosa. Coleção Balangandã, 1971.

FIÚZA. E A galinha ruiva. São Paulo: Moderna, 1996.

O pintinho Quiquiriqui. São Paulo: Moderna, 1995.

FUSARI M.F.R. e O educador e o desenho animado que a criança vê na televisão. São Paulo: Loyola, 1985.

FREINET, C. Pedagogia do bom senso. Sāo Paulo: Martins fontes, 1996.

FREIRE. P. A importância do ato de ler. São Paulo: Cortez, 1996.

Pedagogia da autonomia: saberes necessários à prática educativa. São Paulo: Paz e Terra, 1998

GARDNER. H. A criança pré-escolar. como pensa e como a escola pode ensiná-la. Porto Alegre: Artes Médicas, 1994

Inteligências múltiplas: a teoria na prática. Porto Alegre: Artes Médicas, 1995

GÓES, L. P. A aventura da literatura para crianças: formas de avaliação da literatura infantil e juvenil através da obra de Francisco Marins. São :Raulo: Melhoramentos, 1990

GOING, L.C. Contos para inscrever-se: alfabetização por meio de contos de fada. São Paulo: Vetor, 1997. Versão da tese de dissertação de mestrado Universidade Metodista de São Paulo, 1987.

GUIMARÃES, M.L.A. O tempo e o espaço da alegria na escola: um mergulho nas atividades complementares. São Paulo: Arte \& Ciência, 1999.

GUSDORF, G. Professores para quê?: Para uma Pedagogia da Pedagogia. São Paulo: Martins Fontes, 1995. 
HEINE, H. Amigos. São Paulo: Ática, 1993

HESSE, H. Demian. Rio de Janeiro: Record, 1997.

IDÉ|AS/ Fundação para o desenvolvimento da educação: $N^{0} 7$. O cotidiano da préescola. São Paulo: FDE, 1990.

INOUE, A A., D'AMBROSIO, U. e MIGLIORI, R. Temas Transversais e Educação em Valores Humanos. São Paulo: Peirópolis, 1999

JOLIBERT, J. Formando crianças leitoras. Porto Alegre: Artes Médicas, 1994.

JUNQUEIRA FILHO. G.A. Interdisciplinaridade na pré-escola: anotaçōes de um educador 'on the road'. São Paulo: Pioneira. 1996.

KASSAR, S. As mutações do ensino pré-escolar. In:Tecnologia Educacional, 18. Set/Out, 1977

KRAMER, S. Por entre as pedras: arma e sonho na escola. São Paulo: Ática, 1993.

Com a pré-escola nas mãos: uma alternativa curricular para a educação infantil. São Paulo: Ática, 1995.

KUMARIS. B. Organização. Vivendo valores na escola. São Paulo: Brama Kumaris, 1997

KUPFER, M.C. Freud e a educação: o mestre do impossivel. São Paulo: Scipione, 1995

LAJOLO, M. O que é literatura. São Paulo: Brasiliense, 1995

Do mundo da leitura para a leitura do mundo. São Paulo: Ática, 1999.

LA TAILLE, Y. de et al. Piaget, Vygotsky, Wallon: teorias psicogenéticas em discussão. São Paulo: Summus, 1992.

Limites: três dimensões educacionais. São Paulo: Ática, 1999. 
LÚDKE, M. e ANDRÉ, M.E.D.A. Pesquisa em educação: abordageṇs qualitativas. São Paulo: EPU, 1986.

MACHADO. M. L. A. Pré-escola é não é escola: a busca de um caminho. Rio de Janeiro: Paz e terra, 1991.

MACHADO. N.J. Ensaios transversais: cidadania e Educação. São Paulo: Escrituras, 1997.

MANGUEL, A Uma história de leitura. São Paulo. Schwarcz Ltda, 1997.

MARCELlinO. N. Pedagogia da Animação. São Paulo: Papirus, 1997

MARTINELLI, M. Conversando sobre educação em Valores Humanos. São Paulo: Fundação Peirópolis, 1999.

Aulas de transformação: o programa de educação em valores humanos. São Paulo: Peirópolis, 1996.

MARTINELLI, M.L. et al. O uno e o múltiplo nas relações entre as áreas do saber. São Paulo: Cortez, 1998.

MARTINS. M.H. O que é leitura. São Paulo: Brasiliense, 1994.

MEIRELES, C. Problemas da literatura infantil. Rio de Janeiro: Nova Fronteira, 1984.

Criança meu amor...Rio de Janeiro: Nova Fronteira, 1977

MELLO, T. de. Faz escuro mas eu canto: porque a manhã vai chegar. Rio de Janeiro: Bertrand Brasil, 1999.

MRECH, L. M. Psicanálise e Educação: novos operadores de leitura. São Paulo: Pioneira, 1999.

NICOLAU, M. L.M. A educação pré-escolar. fundamentos e didática. São Paulo: Ática, 1995. 
e MAURO, M. A. F. Alfabetizando com sucesso: a comunicação e a expressão da criança. São Paulo: EPU, 1986.

NÓVOA, A. Profissão professor. Portugal: Porto Editora, 1995.

NUNES. N.N. Pré-escola em tempo de espera.(Um estudo sobre o processo de ingresso na EMEl). Tese (Mestrado em Educação: História e Filosofia da Educação) - Faculdade de Educação, Universidade de São Paulo, 1995.

OAKLANDER. V. Descobrindo crianças; abordagem gestáltica com crianças e adolescentes. São Paulo: Summus, 1980.

OLIVEIRA. M.K de Vygotsky: aprendizado e desenvolvimento-um processo sóciohistórico. São Paulo: Scipione, 1997.

PÁTIO REVISTA PEDAGÓGICA. Vivendo valores na escola: quais e como? Porto Alegre: Artmed, Ano 4, n 13, Maio/julho/2000.

PAVONI, A. Os contos e os mitos no ensino: uma abordagem junguiana. São Paulo: EPU. 1989

PENNAC, D. Como um romance. Rio de Janeiro: Rocco, 1995.

PERROTTI, E. Confinamento cultural, infância e leitura. São Paulo: Summus, 1990.

PESSOA, F. Mensagem. São Paulo: Difel, 1986.

PIAGET, J. O juizo moral na criança. São Paulo: Summus, 1994. 1996. et al. Cinco estudos de educação moral. São Paulo: Casa do Psicólogo,

PUIG, J. Etica e Valores: métodos para um ensino transversal. São Paulo: Casa do Psicólogo, 1998a. A construção da personalidade moral. São Paulo: Ática, 1998 b. 
PORTO, C. A festa no céu. São Paulo: Moderna, 1995.

QUINN, D. Ismael. Fundação Peirópolis, 1998.

QUINTANA, M. Lili inventa o mundo. Porto Alegre: Mercado Aberto, 1997.

RATHS, L. E. et al. Ensinar a pensar. São Paulo: EPU: 1977.

RENNÓ, R. A de amigo. Curitiba: Arco Íris; 1995.

Amor de ganso. Curitiba: Arco íris, 1995.

Pela porta do coração. São Paulo: FTD, 1996.

RIBEIRO. L. C. Os três porquinhos. São Paulo: Moderna, 1996.

RIOS, T A Ética e competência. São Paulo: Cortez, 1997.

RODARI. G. Gramática da fantasia. São Paulo: Summus, 1982.

ROCHA. R. Procurando firme. Rio de Janeiro: Nova Fronteira, 1984.

ROSSETTI. F. Educação: ciência do cérebro valoriza idade pré-escolar. Folha de São Paulo, $21 \mathrm{abr} . / 1997$.

SALINGER, J.D. O apanhador no campo de centeio. Rio de Janeiro: Do Autor, 1951

SANDRONI, L. e MACHADO, L.R. A criança e o livro: guia prático de incentivo à leitura. São Paulo: Ática, 1991.

SÃO PAULO. Secretaria Municipal de Cultura. Departamento de bibliotecas infantojuvenis. Seção de bibliografia e documentação da biblioteca infanto-jựęnil Monteiro Lobato. Bibliografia Brasileira de Literatura Infantil e Juvenil. São Paulo, 1998.

SCHMÖGNER, W. O livro do dragão. São Paulo: Melhoramentos, 1975. 
SILVA, L.B. Histórias da Carochinha. São Paulo: Ática, 1986.

SNYDERS, G. Alegria na escola. São Paulo: Manole, 1988.

SOIFER, R. A criança e a TV: uma visão psicanalitica. Porto Alegre: Artes Médicas, 1991

TAHAN, M. Os melhores contos. Rio de Janeiro: Record, 1995.

TELES, M.L.S. Filosofia para jovens: uma iniciação à filosofia. Petrópolis, Rio de Janeiro: Vozes, 1996

TRIVIZAS, E. Os três lobinhos e o porco mau. São Paulo: Brinque-Book, 1996.

VILELA, L. Contos da infância e da adolescência. São Paulo: Ática, 1996.

VYGOTSKY, L.S. Pensamento e linguagem. São Paulo: Martins Fontes, 1995.

WEISZ, T. O diálogo entre o ensino e a aprendizagem. São Paulo: Ática, 1999.

ZILBERMAN, R. et al. Leitura: perspectivas interdisciplinares. São Paulo: Ática, 1995

(org). Leitura em crise na escola: as alternativas do professor. Porto Alegre: Mercado Aberto: 1982.

e MAGALHÃES, L.C. Literatura Infantil: autoritarismo e emancipação. São Paulo: Ática, 1987. 


\section{Anexo}

\section{Projeto}

Literatura Infantil:

uma viagem de transformação através dos Valores Humanos 


\section{Primeiro momento}

\section{Implementação do projeto: figuras e fotos}




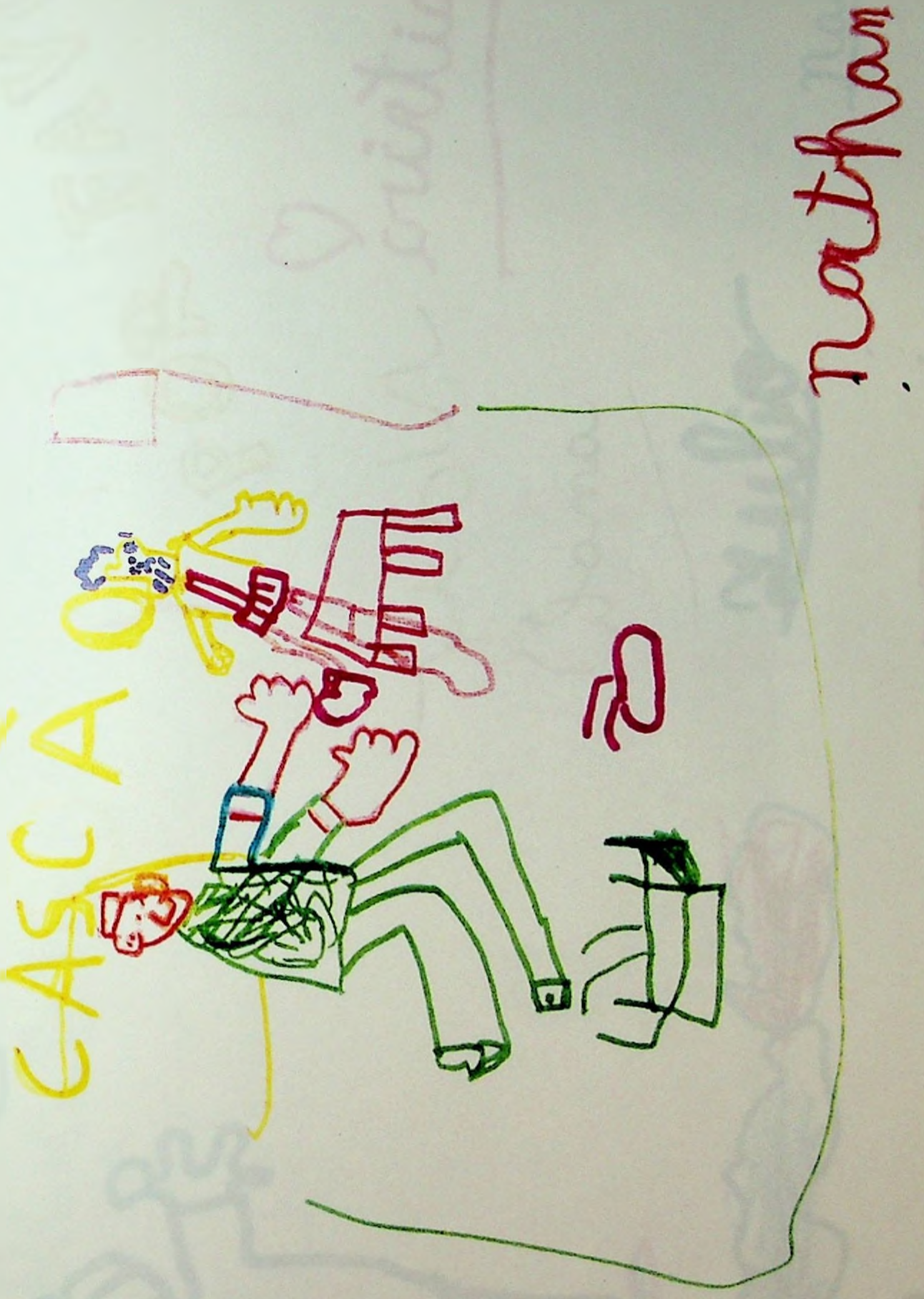


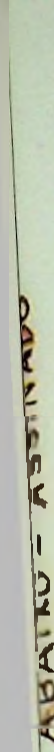
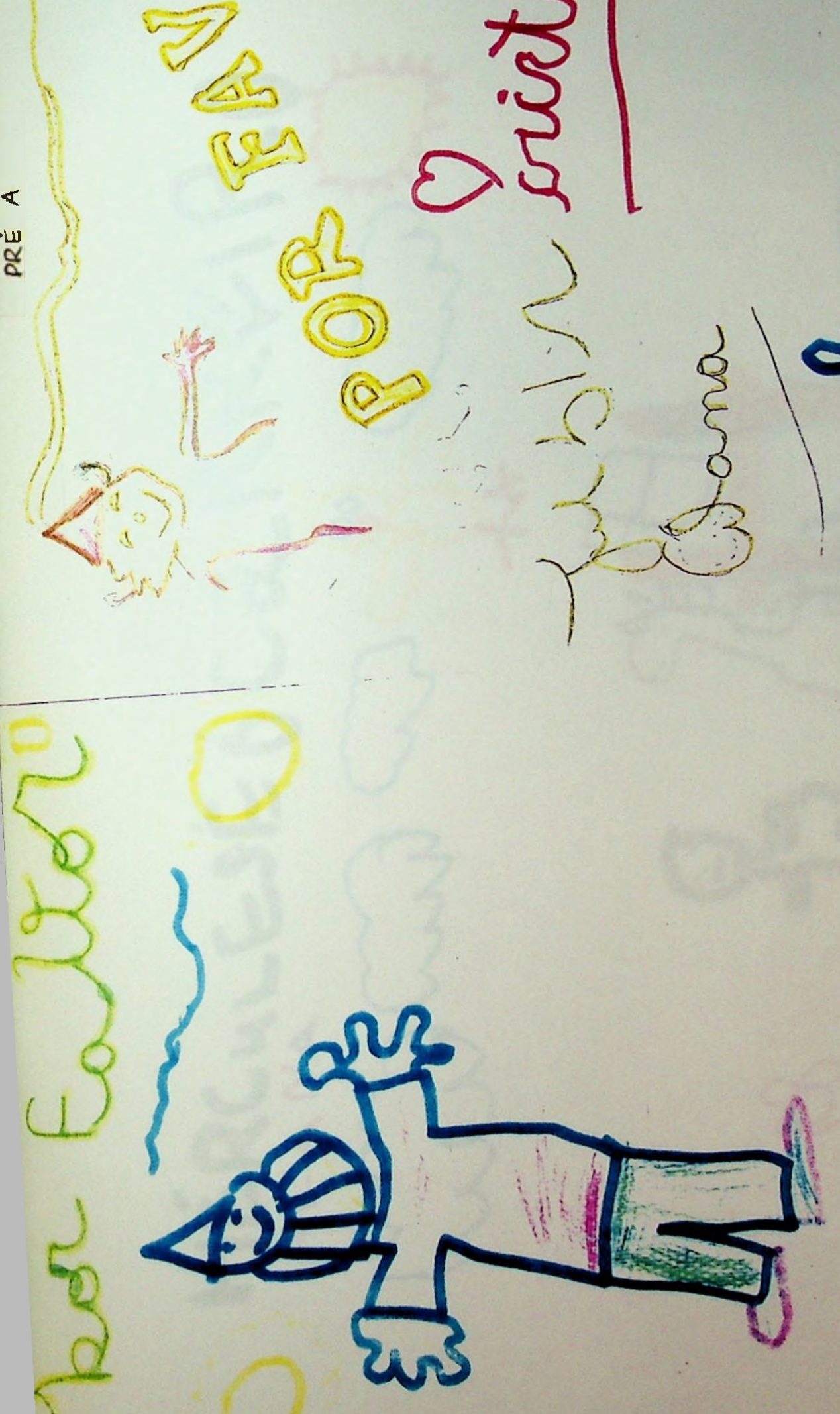

ran

S
\&) Figura 4

$+2$

8

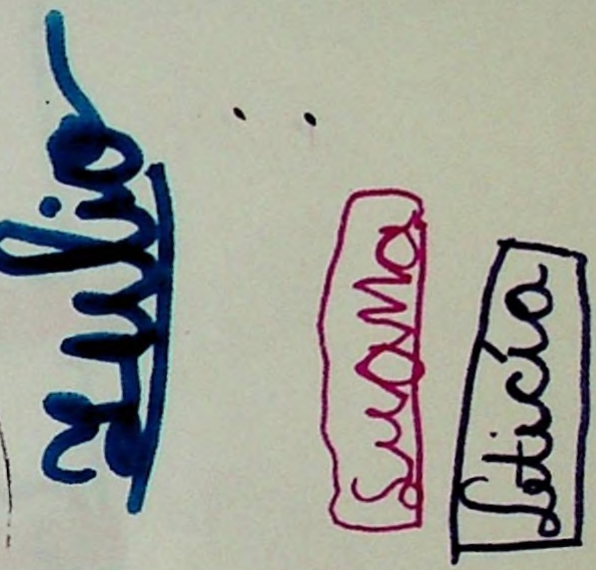

Figura 5 ,

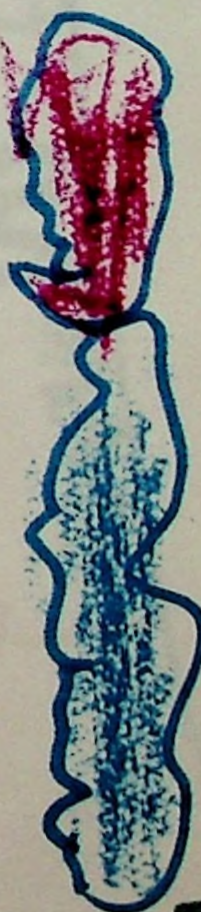

II

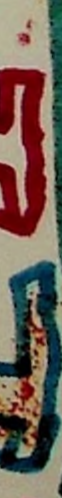


함

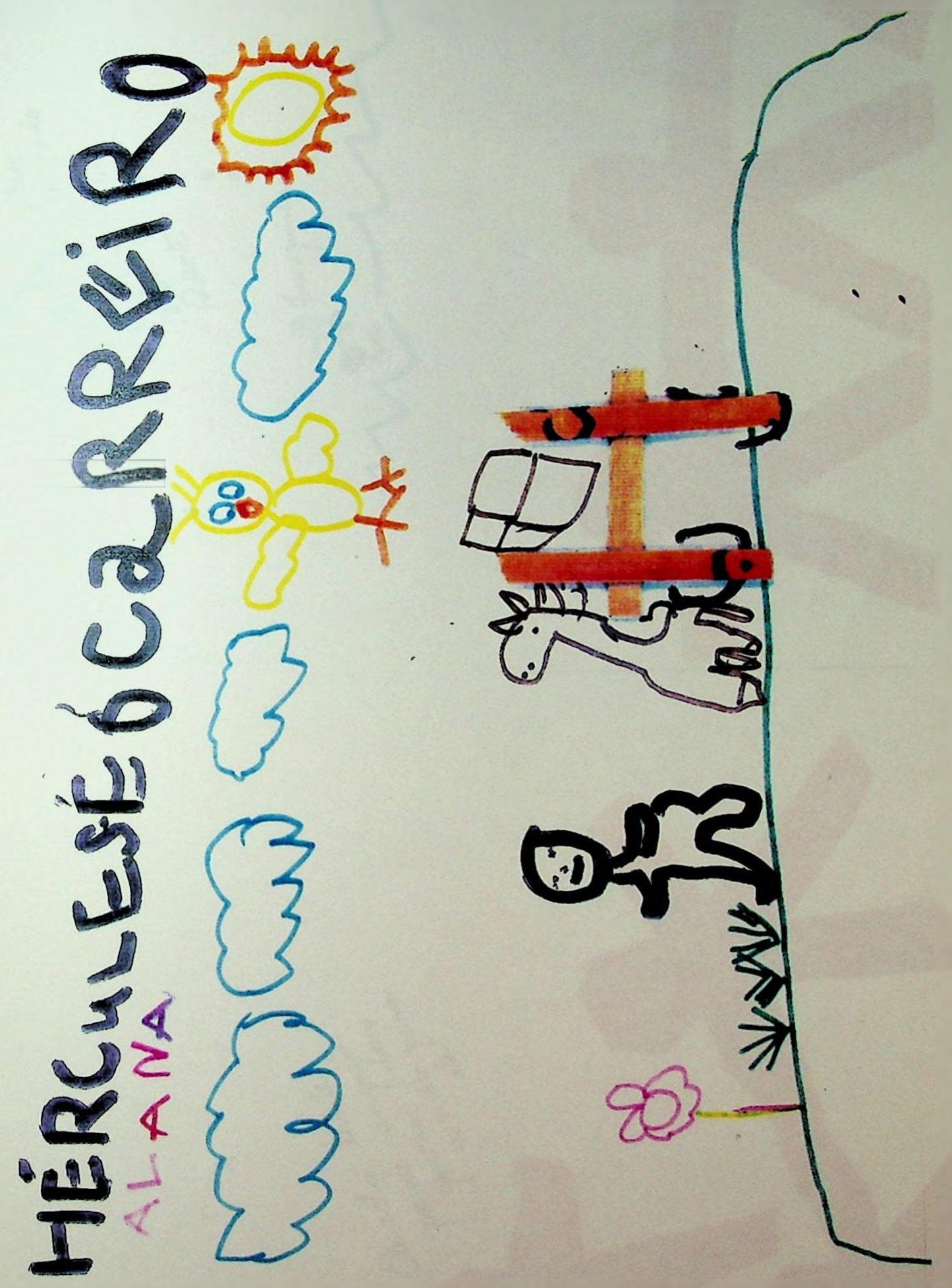



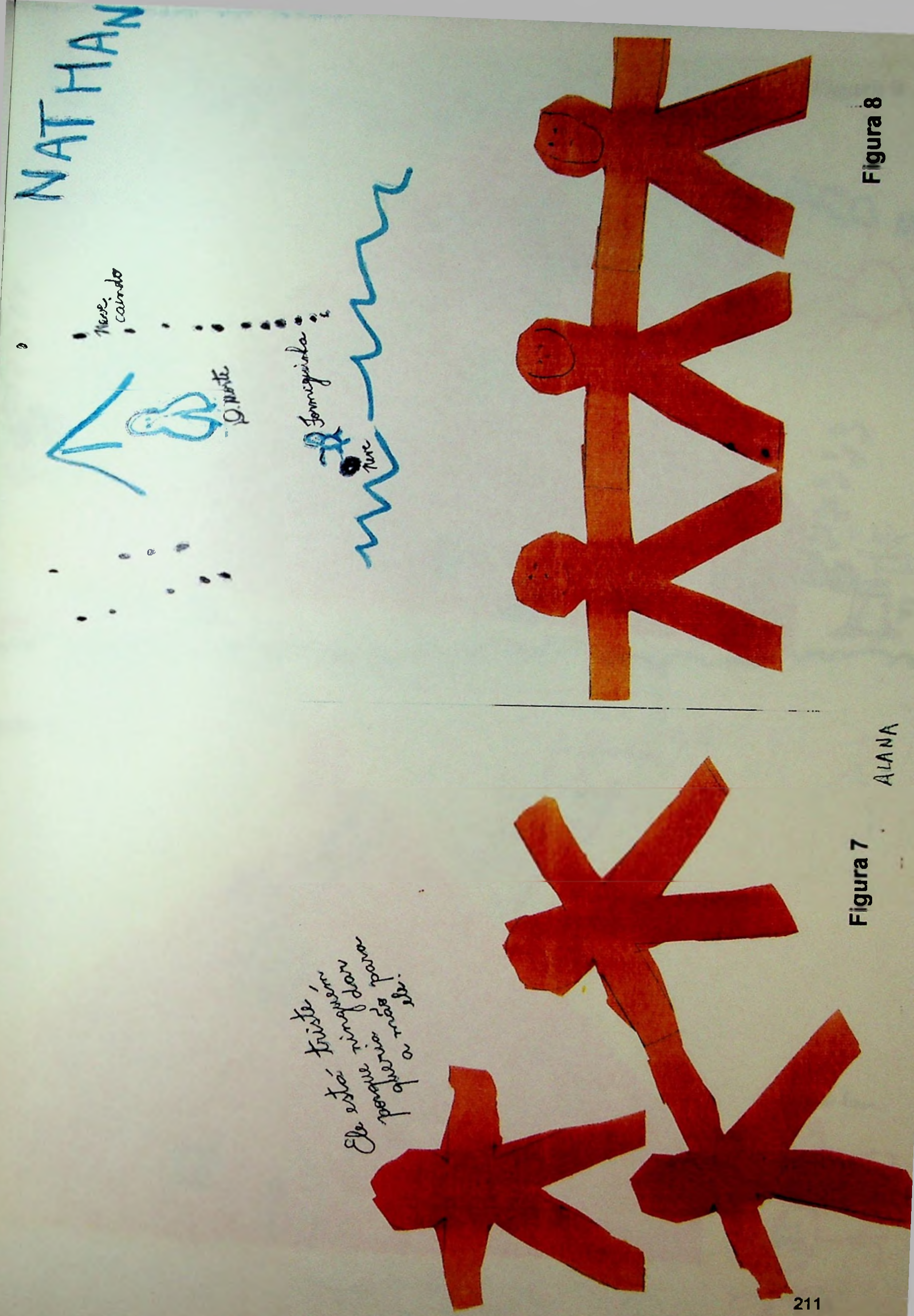
OS TRAS LOPINHOE Figura

(1)
(2)

ob

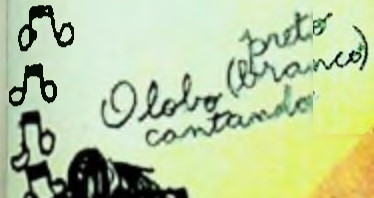

Don

Qlforest
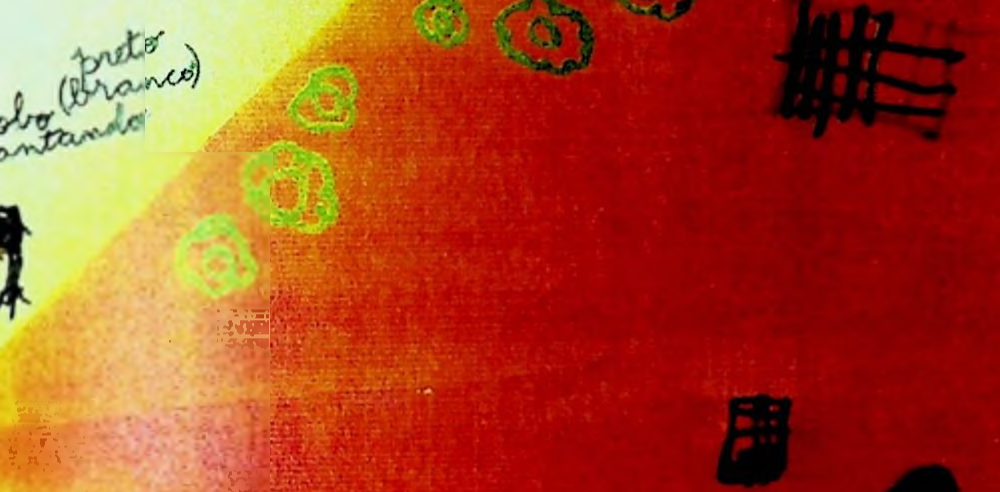

Nome: Karum

-igura 10

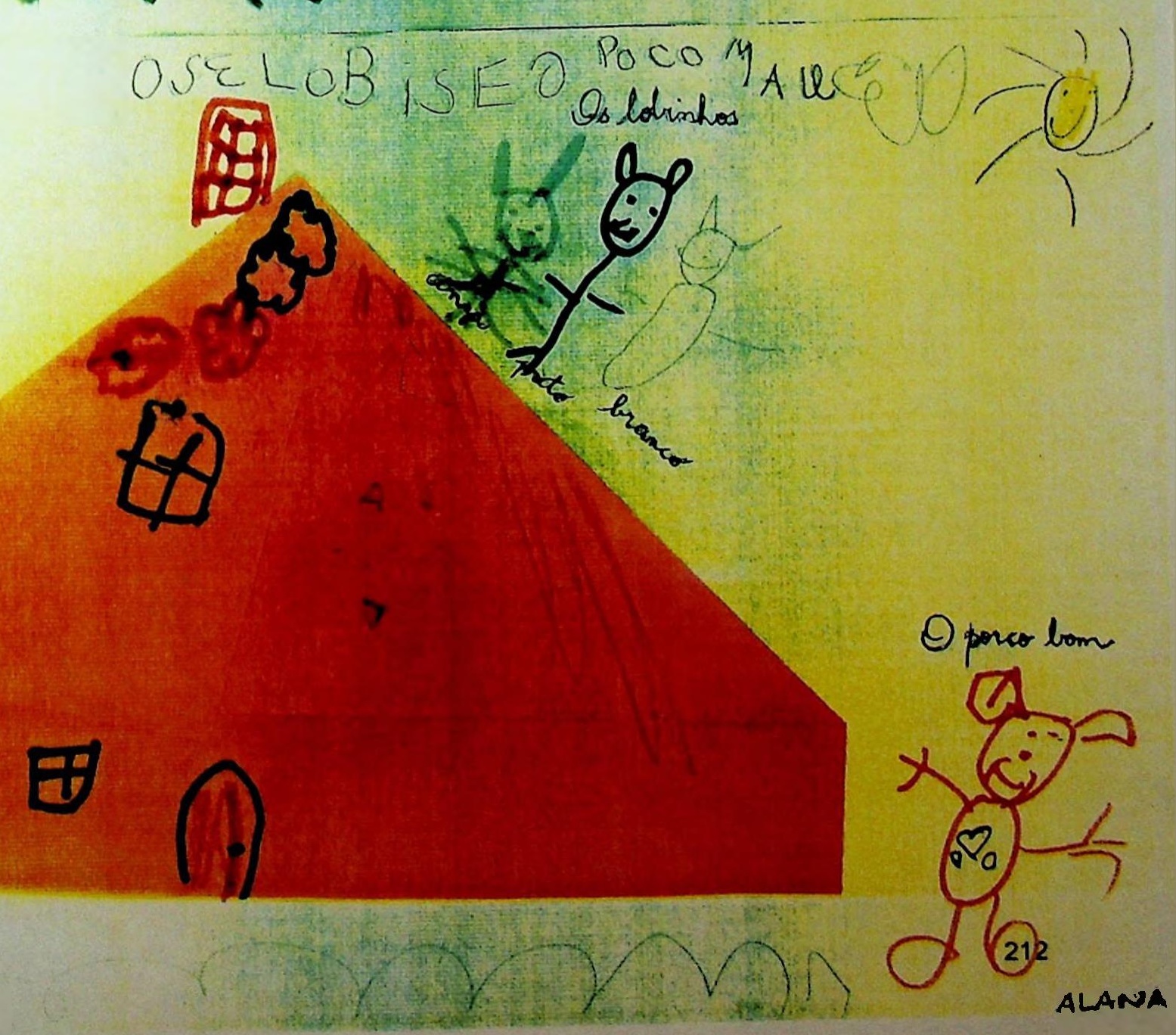




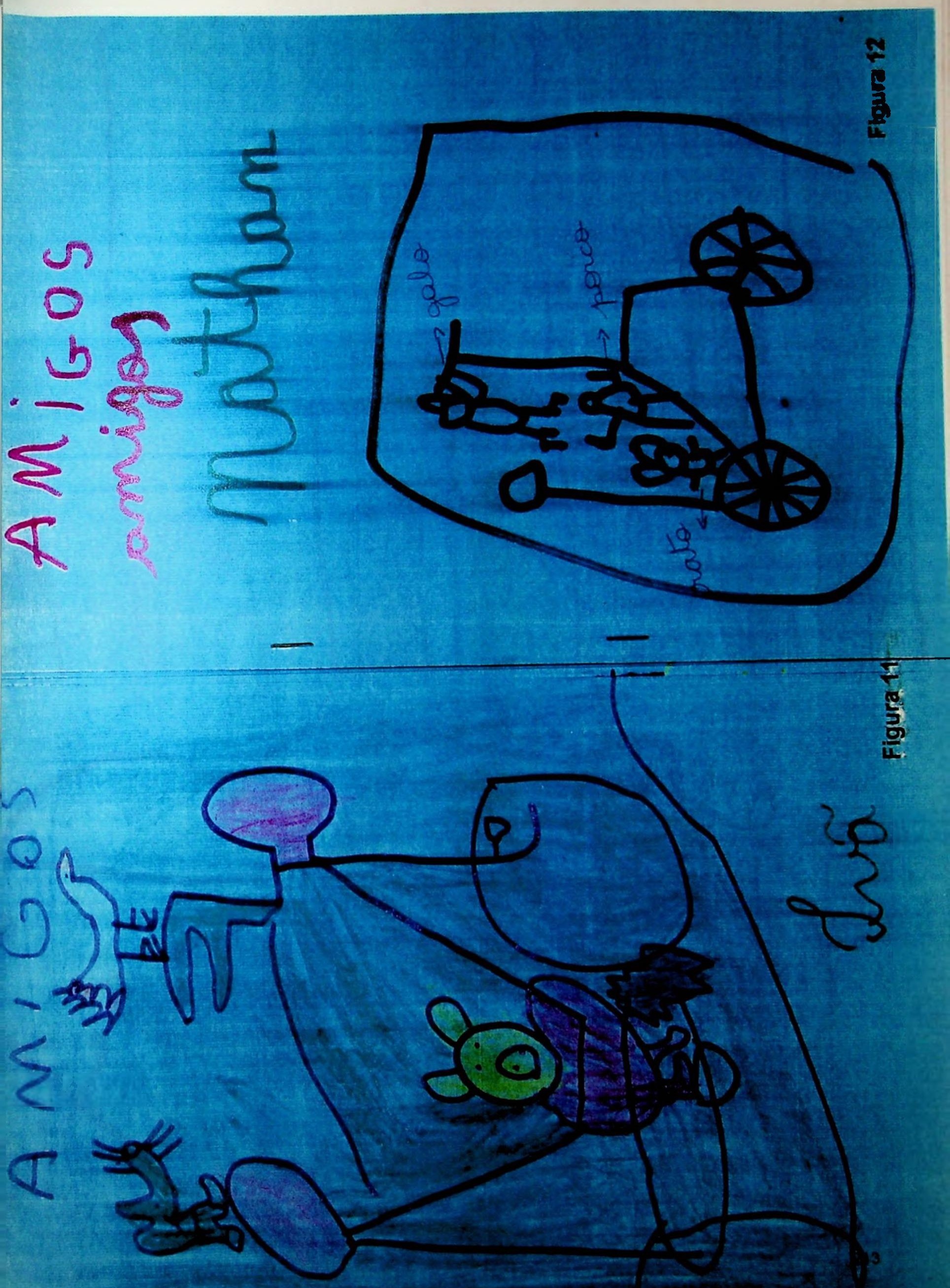



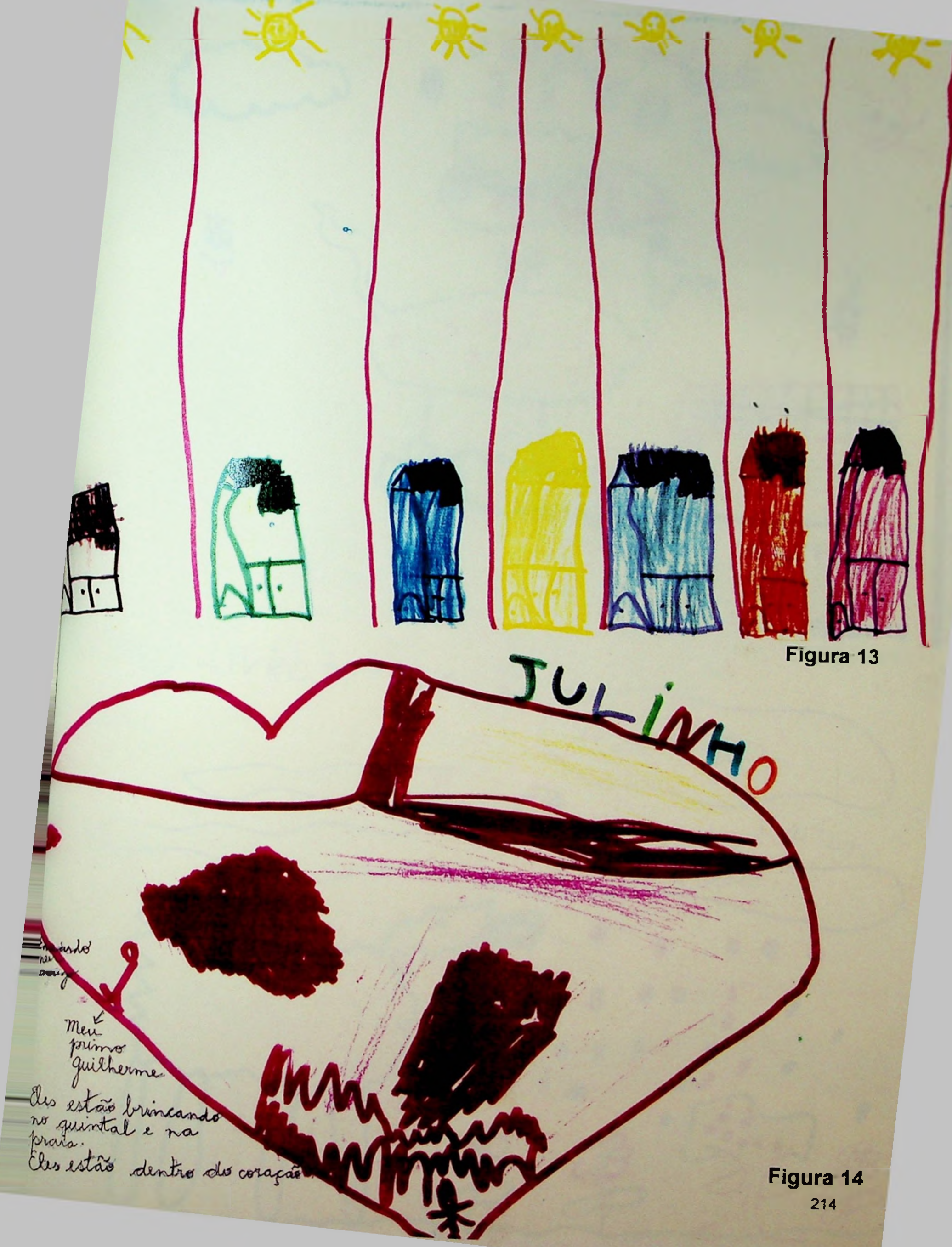


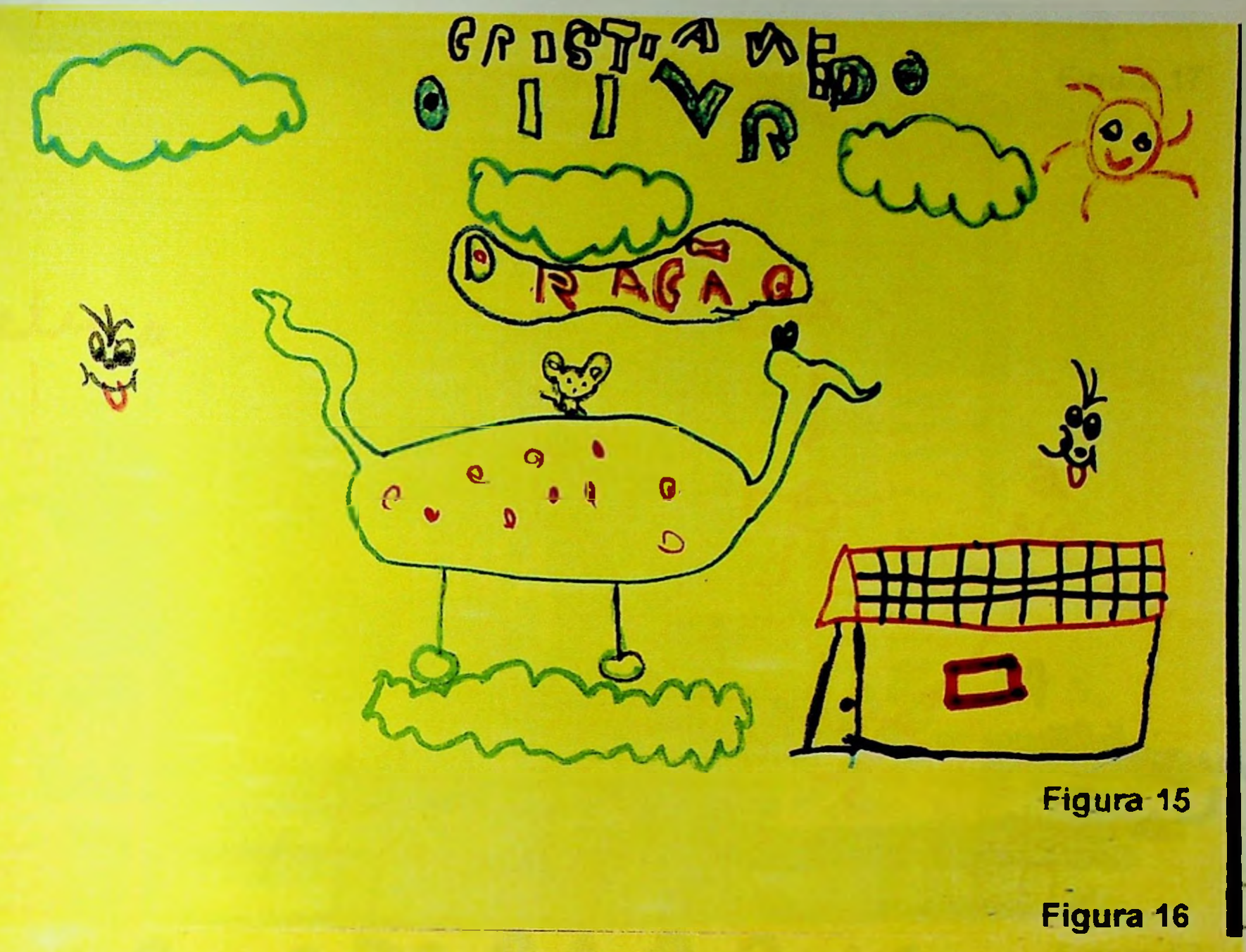

OLIVRODO DRAGÃO 
ratham cumiges do

parape

Figura 17

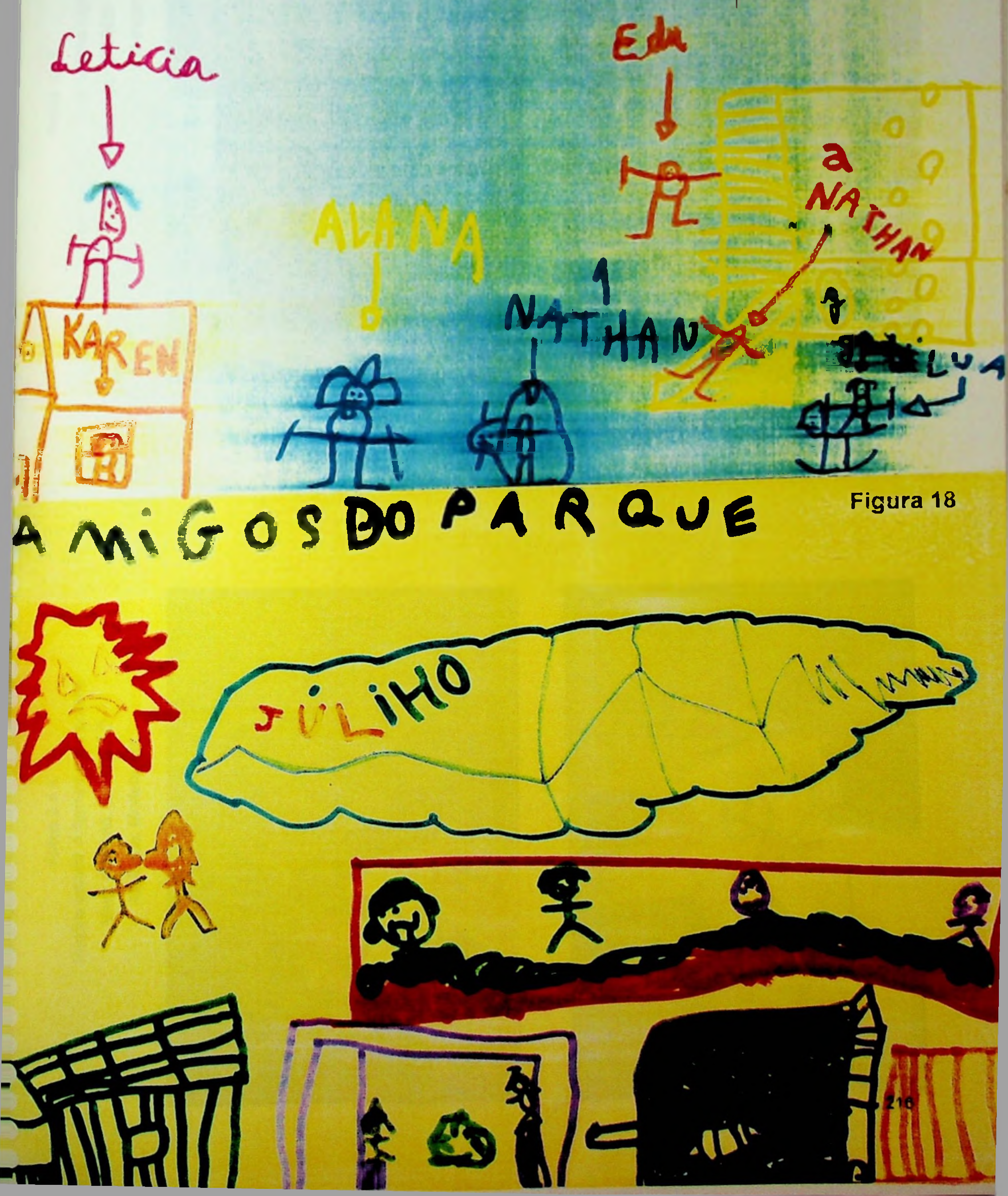



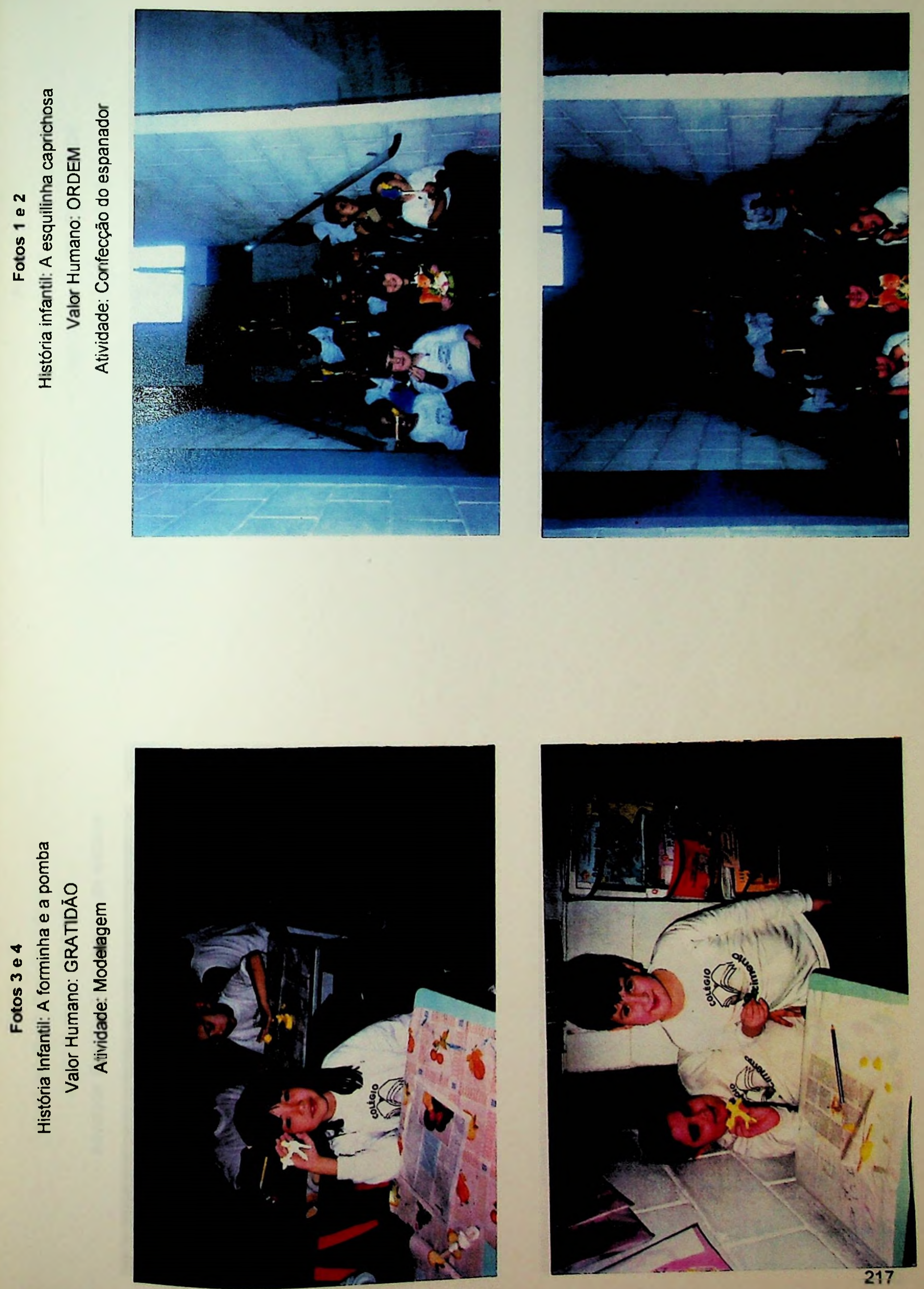

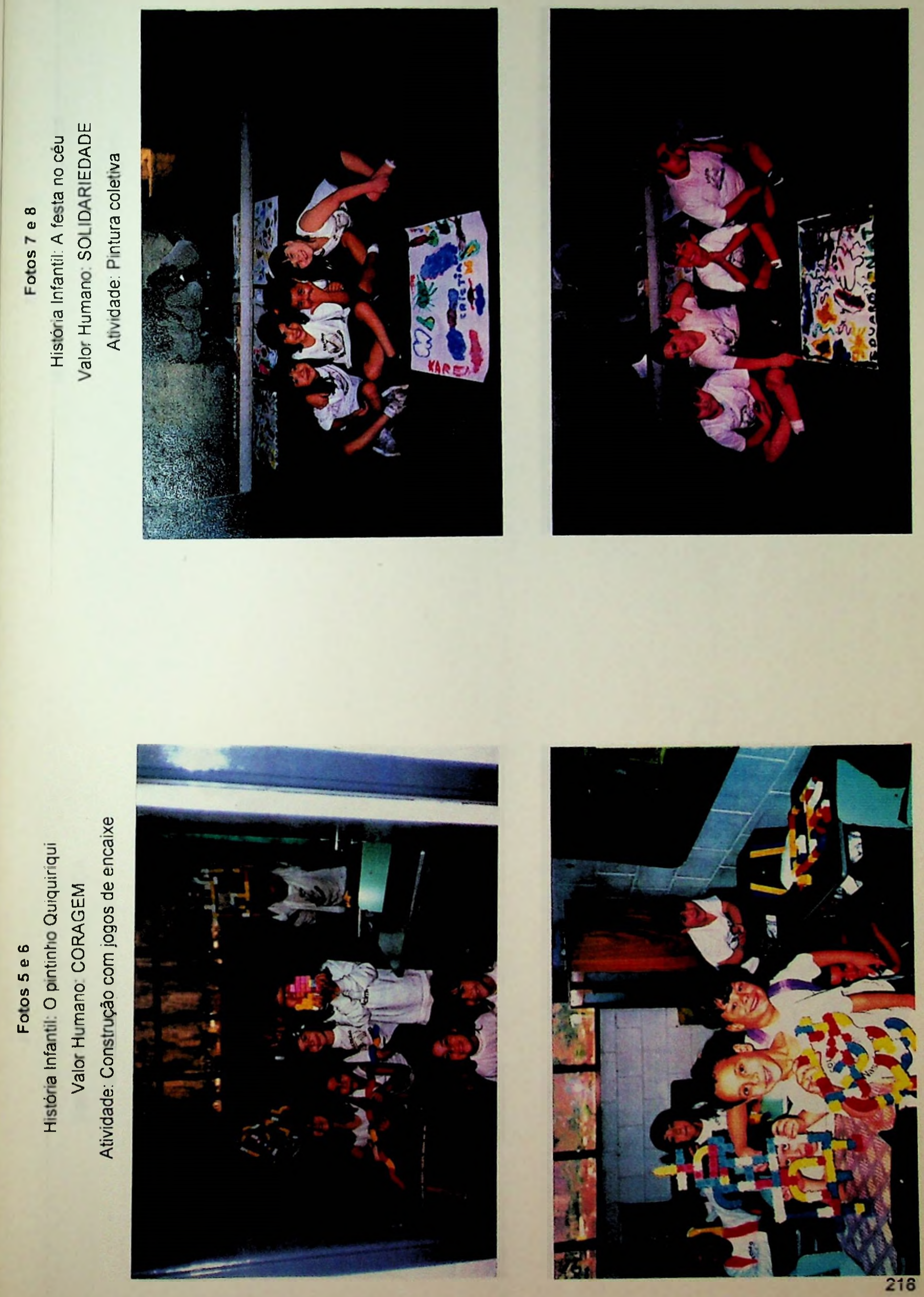

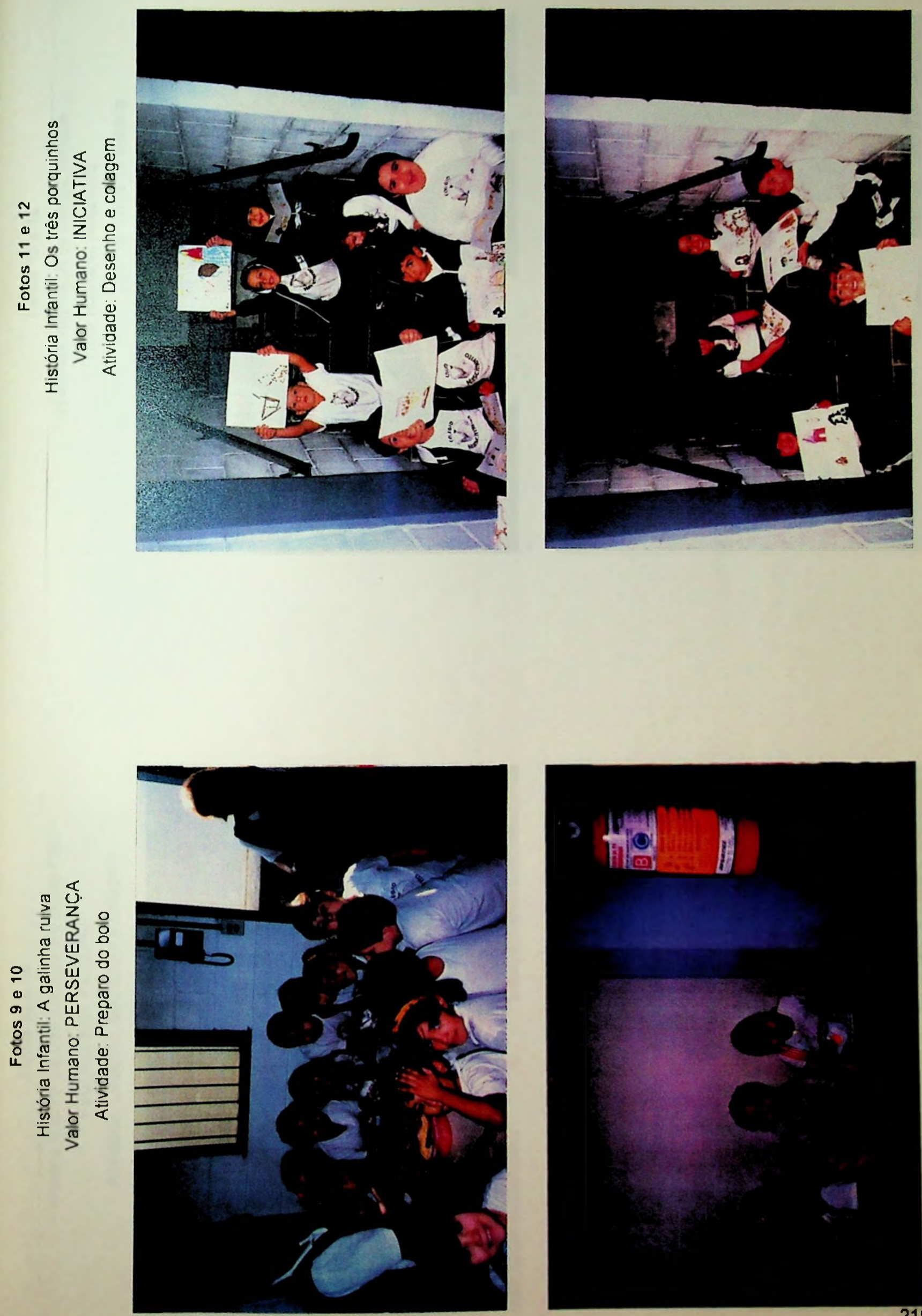

내일 

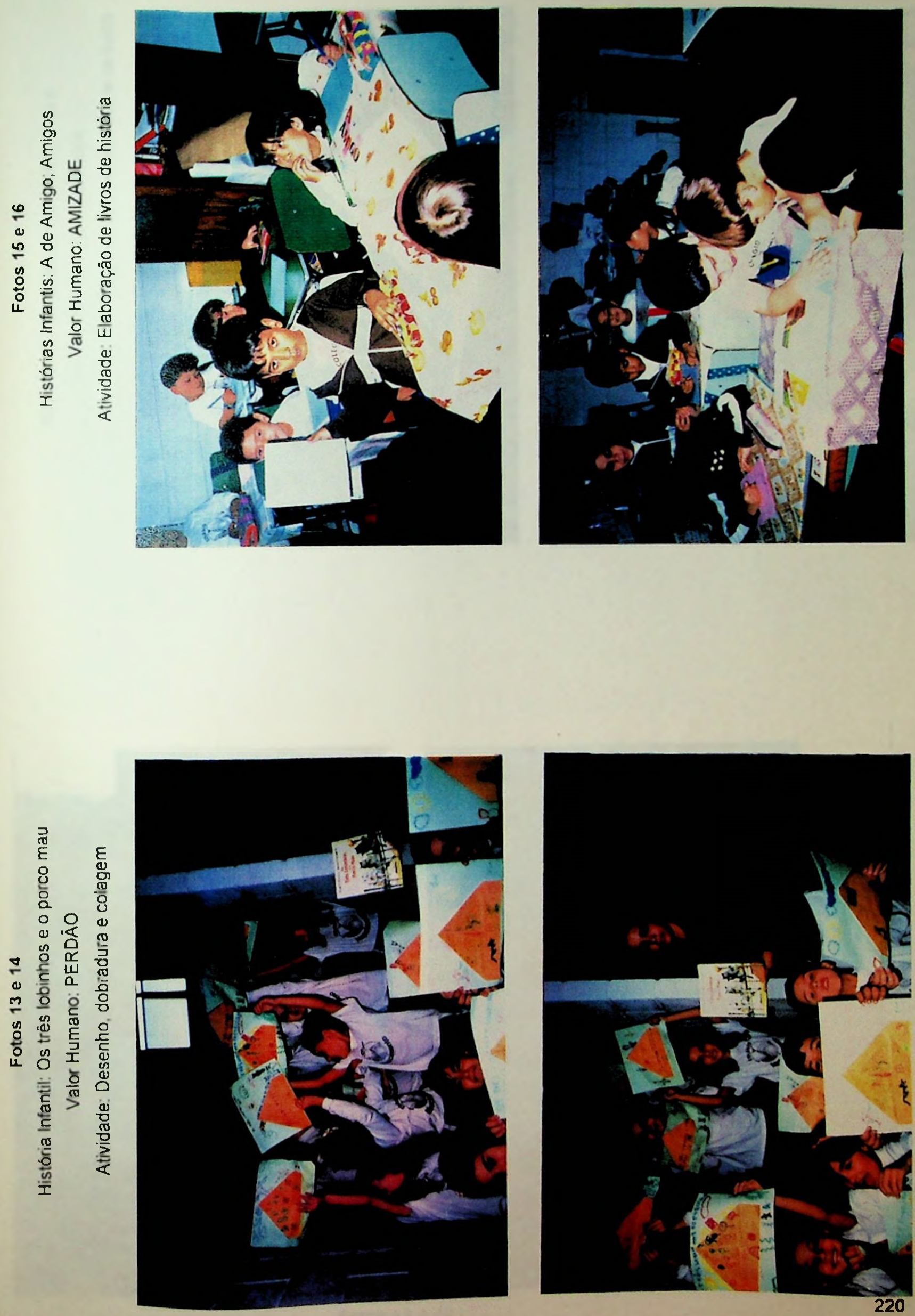

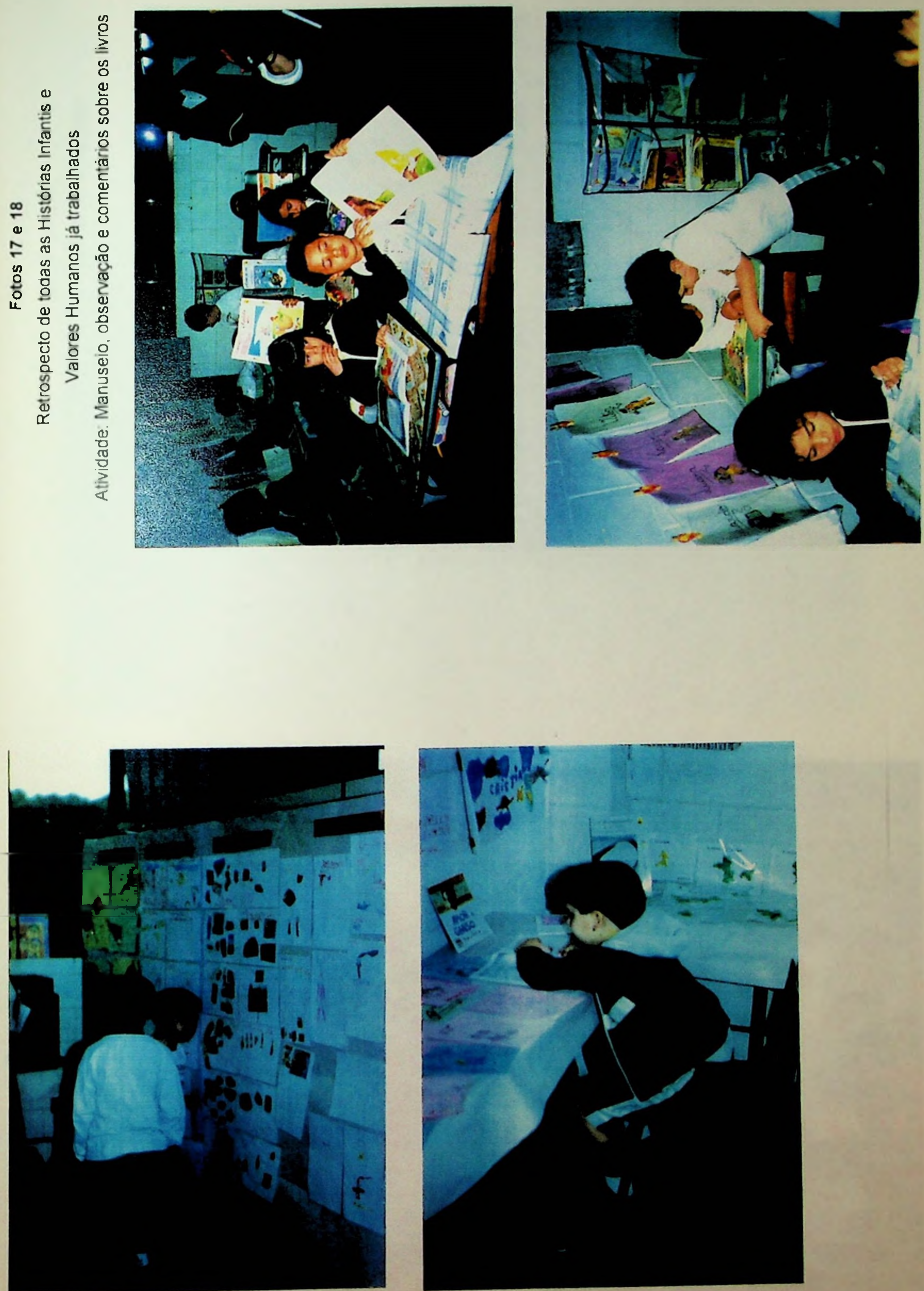

Fotos 19 e 20

I Feira Cultural do Colégio Nascimento

Exposição de atividades do presente projeto pelo Pré $A$ 

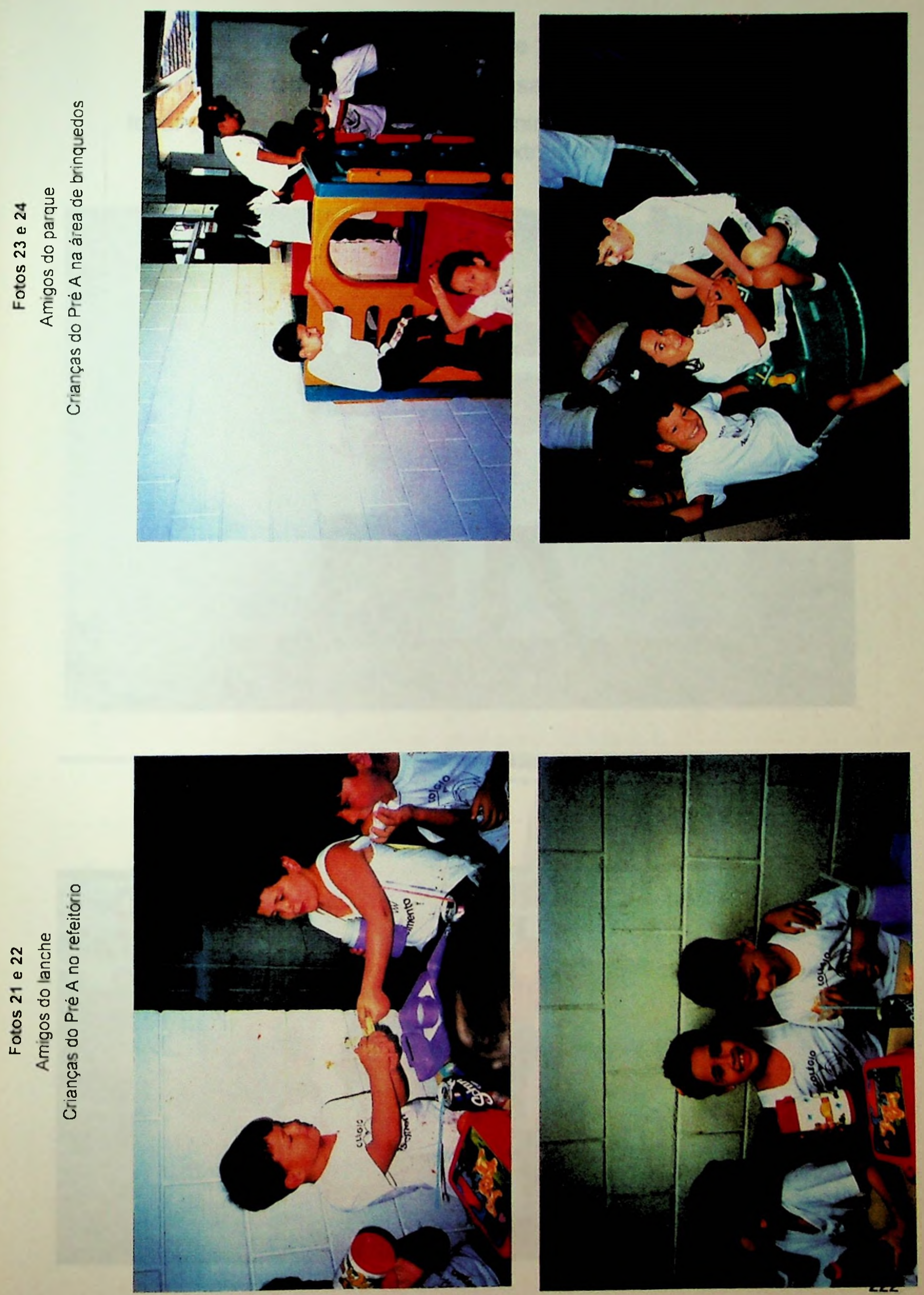
Fotos 25 e 26

Crianças do Pré A no salão da escola,

local onde costumávamos nos reunir para ouvir/contar histórias e realizar atividades extraclasse
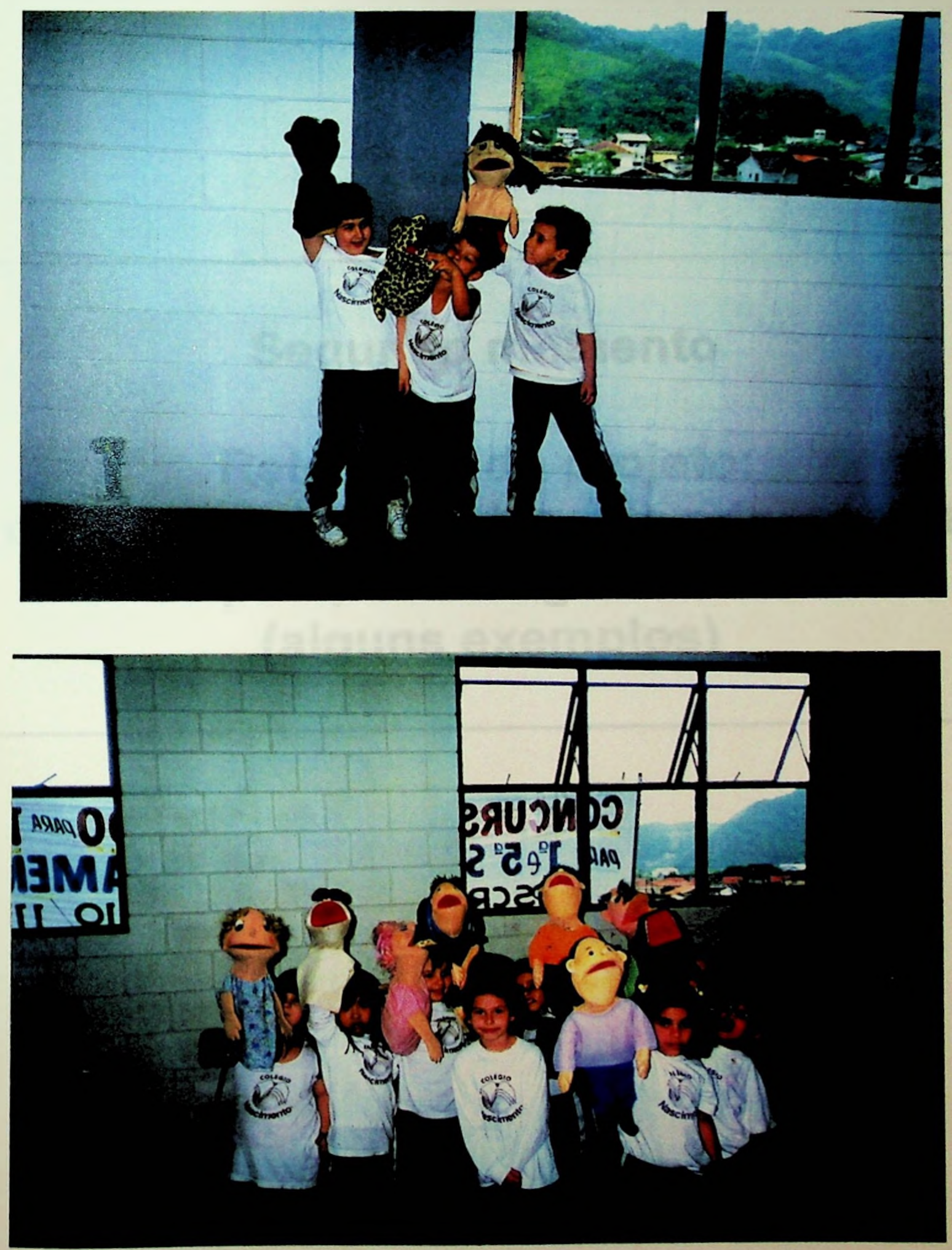


\section{Segundo momento}

Retomada do projeto:

desenhos e atividades das crianças na pesquisa longitudinal (alguns exemplos) 
Atividades das crianças:

$10 / 02 / 2000$ 


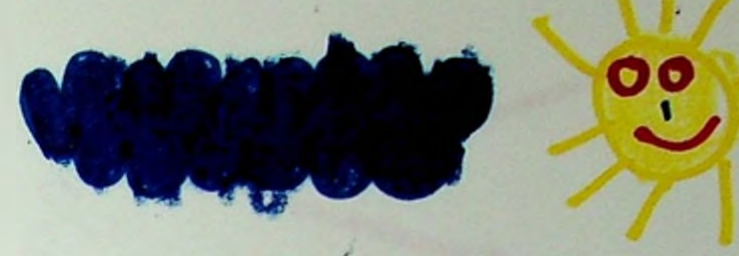

Rela porta do coração

0 meni

(0)

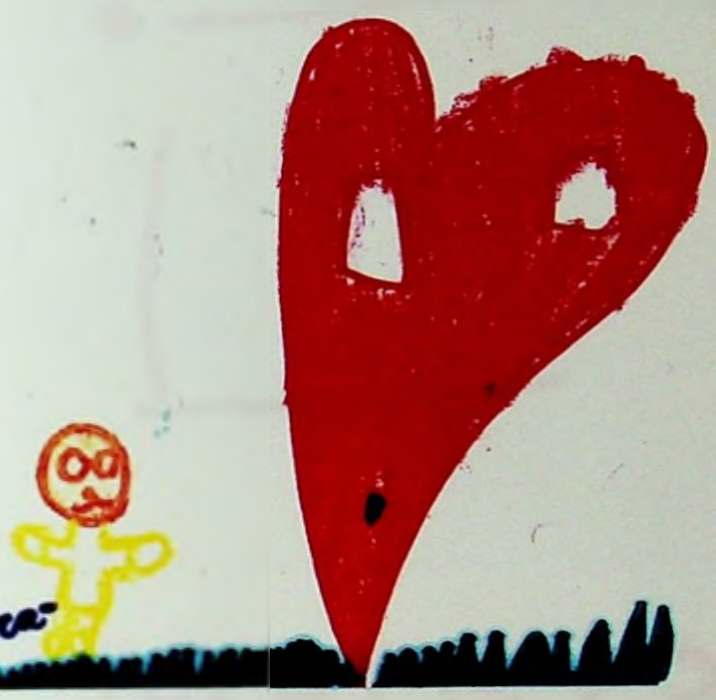
foi posa

A Esquilimba caprucha

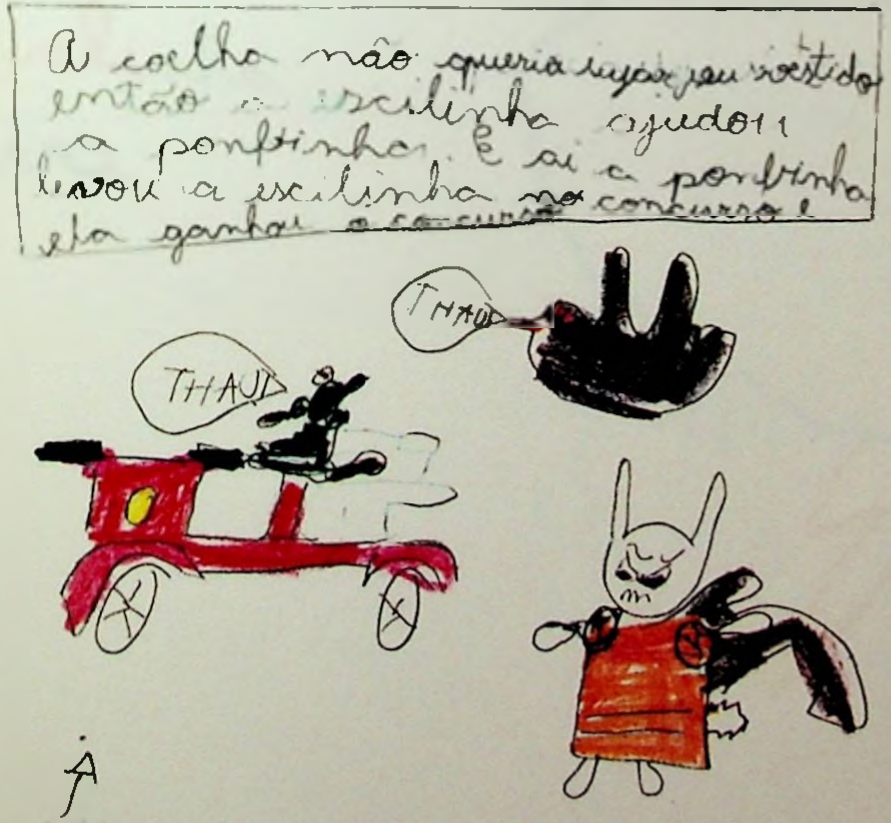

DEPOISNOCONCWRSO

Mam.
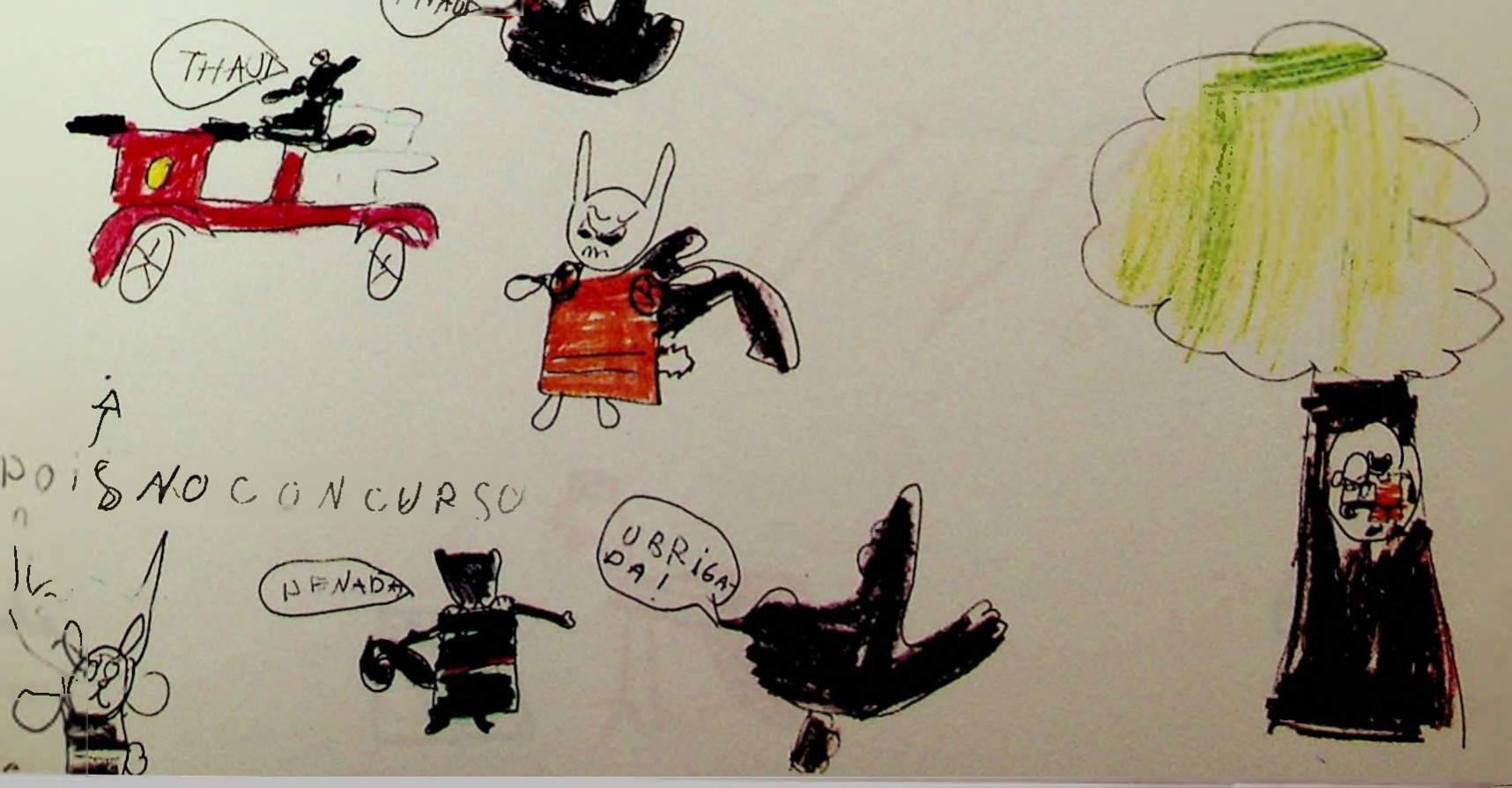

Atividades das crianças:

$22 / 02 / 2000$ 


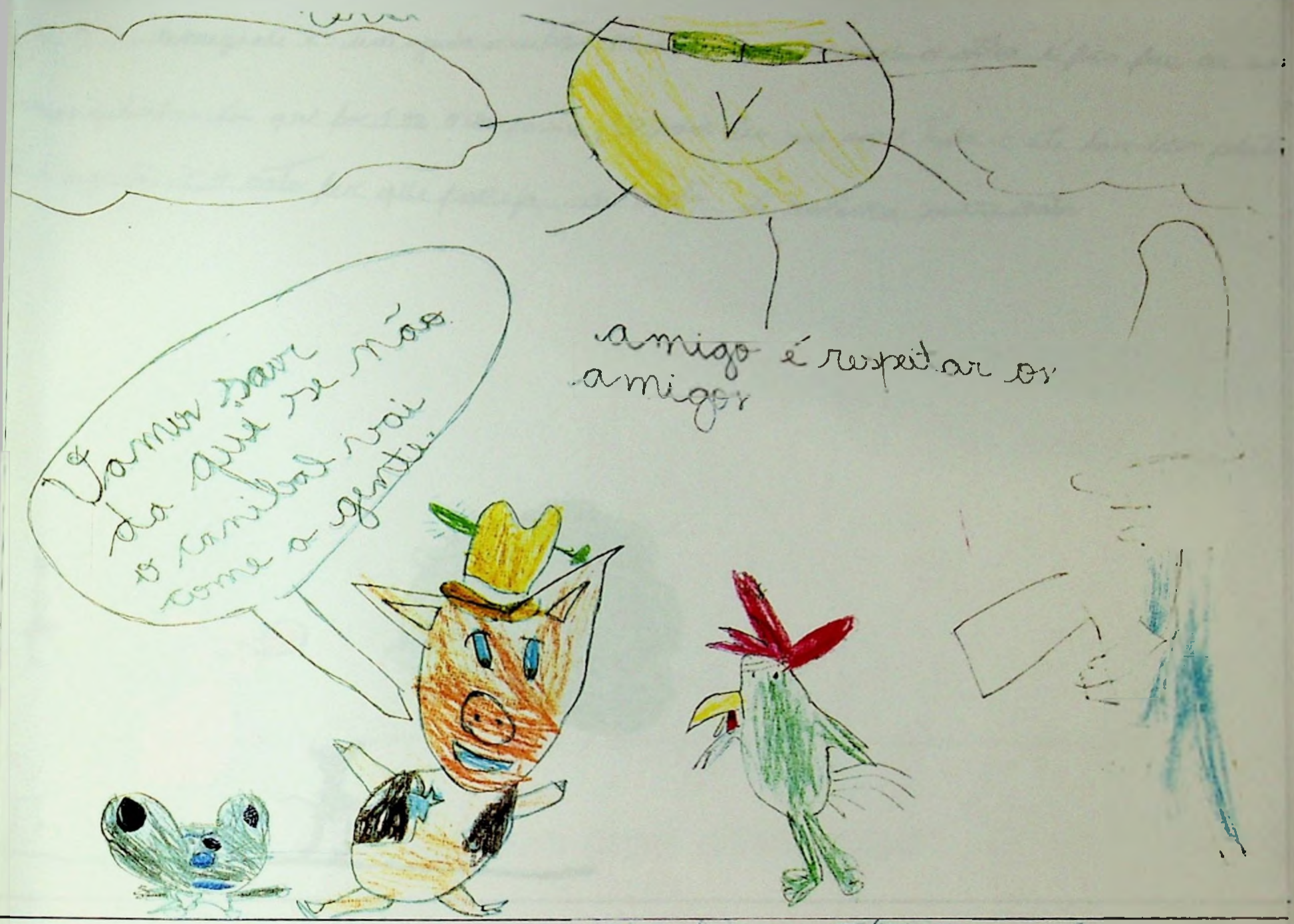

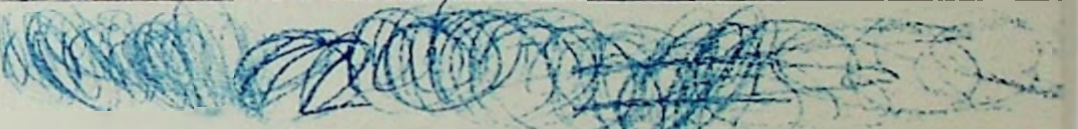
Q) arenticuvos ira uma nseg trîn amiger

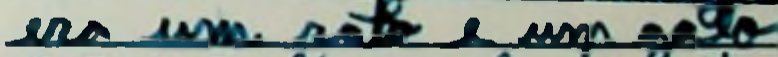
- o nopce nomed de cato ara firedarices mme dogats T) Whademar
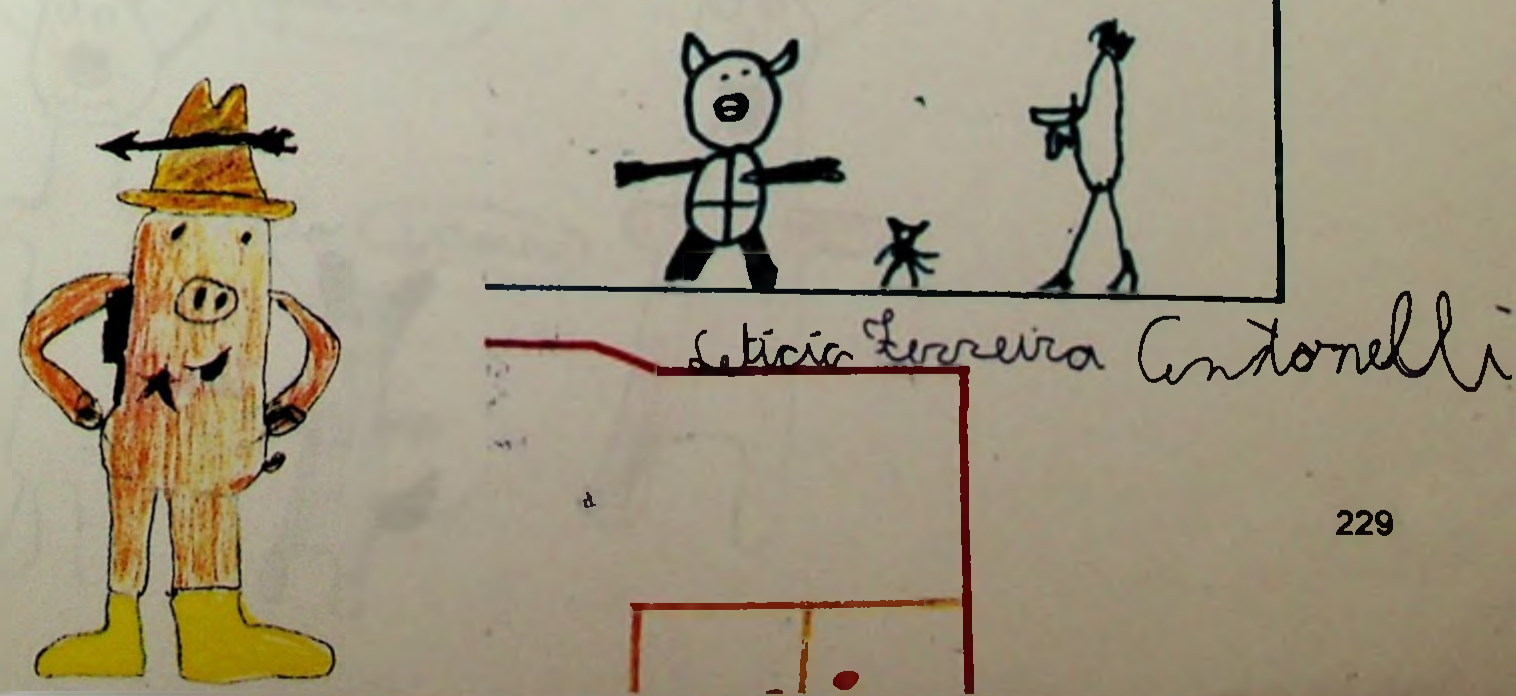
Atividades das crianças:

$23 / 02 / 2000$ 
La belma in te amodo men coracino.

Karen

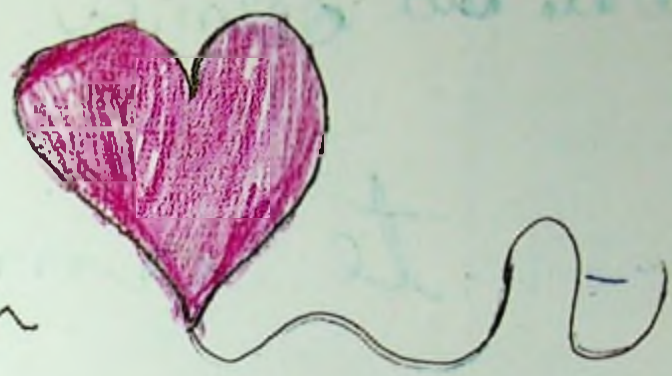

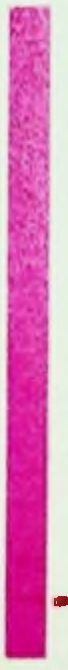

- La delima en Luesa criza or da tozinc ar mustor Sons. Jum2

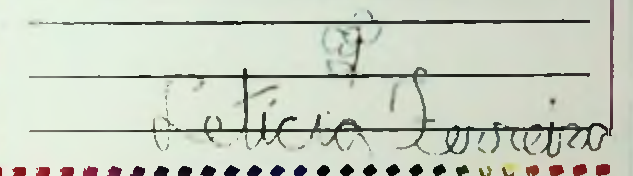

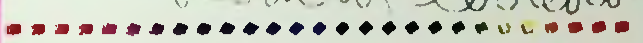

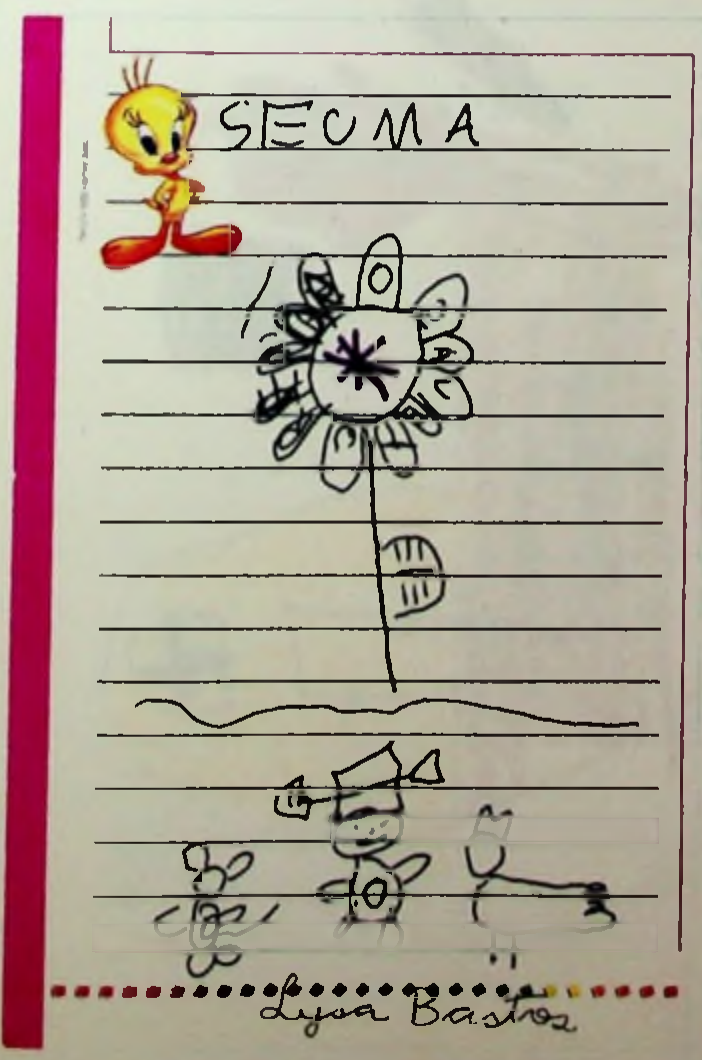

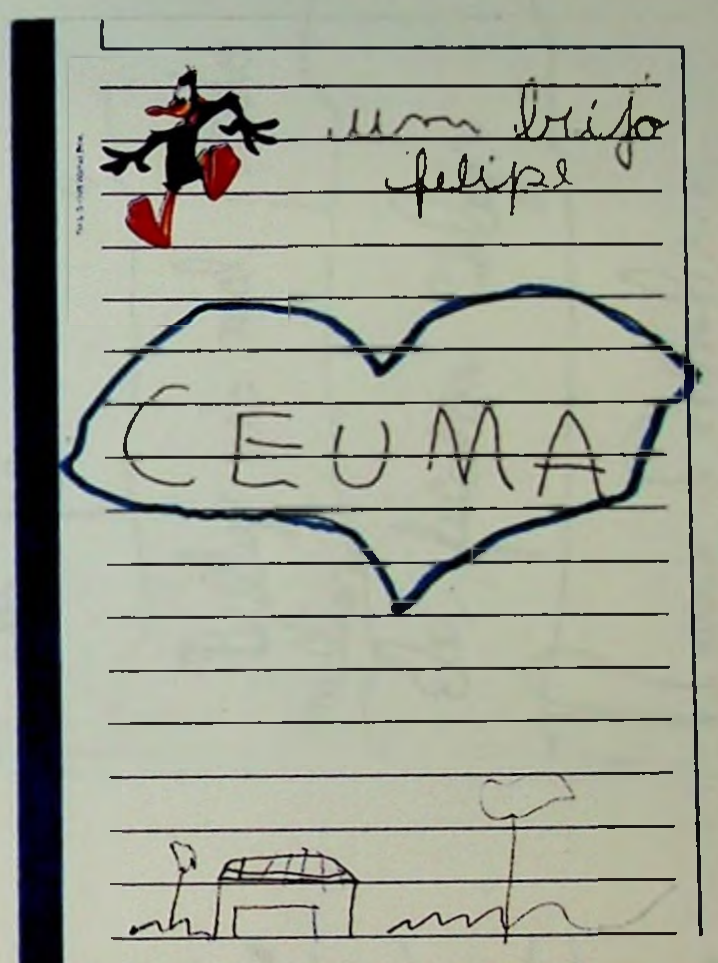

Jia Selma

Nem te conhezo dirato.E us já oest da senfora tclaw $\frac{\text { Moll beipsear }}{\text { Sefucia sarco }}$ 


$$
\begin{aligned}
& \frac{-3}{\frac{3}{3}} \\
& \text { के } \\
& \text { \% } \\
& \text { ? } 3 \\
& 5,4 \text { के } \\
& \text { 今- 总 } \\
& 5 \text { 妾 } \\
& \text { से के }
\end{aligned}
$$

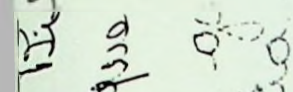

$$
\begin{aligned}
& e^{\infty} \omega^{\infty}
\end{aligned}
$$
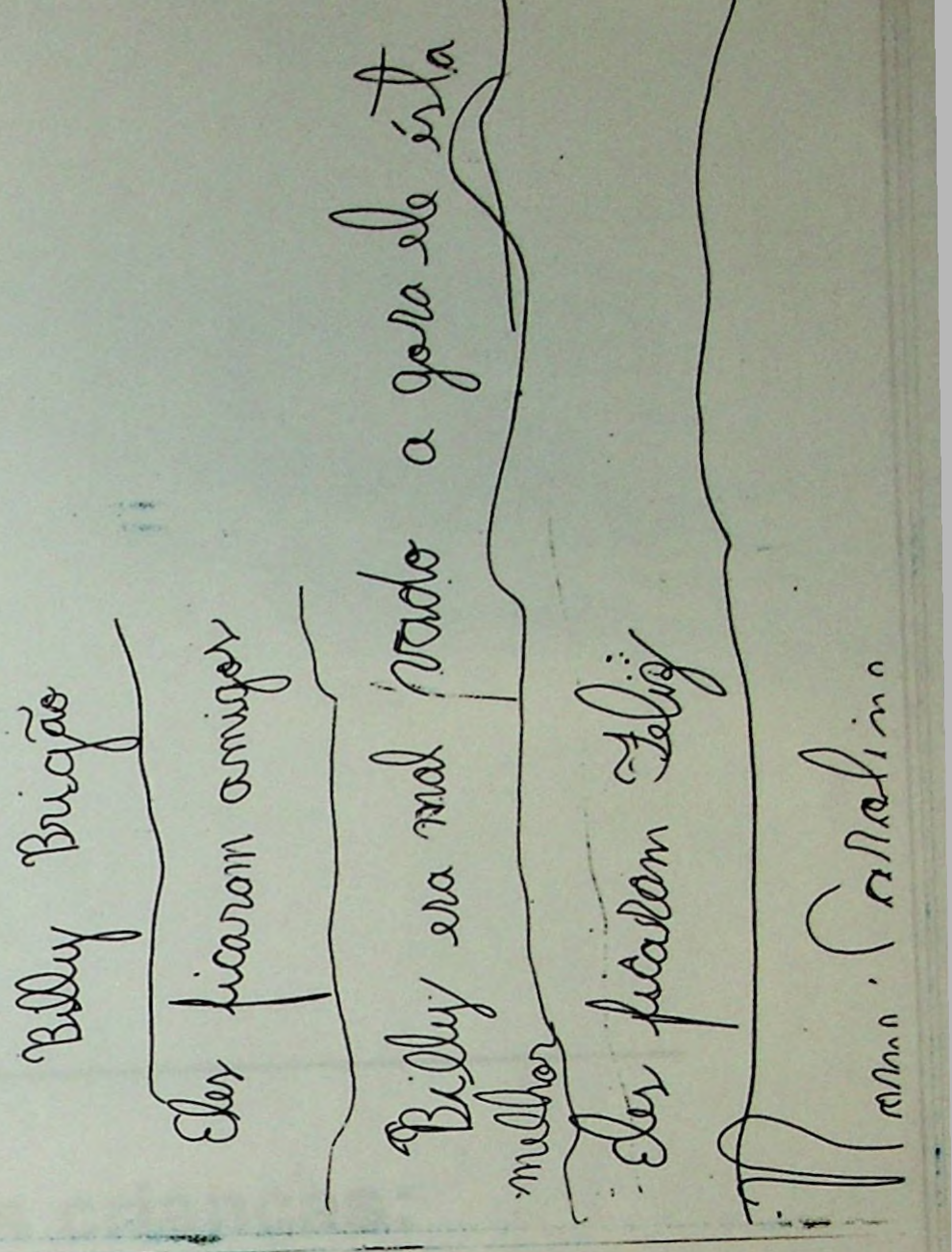

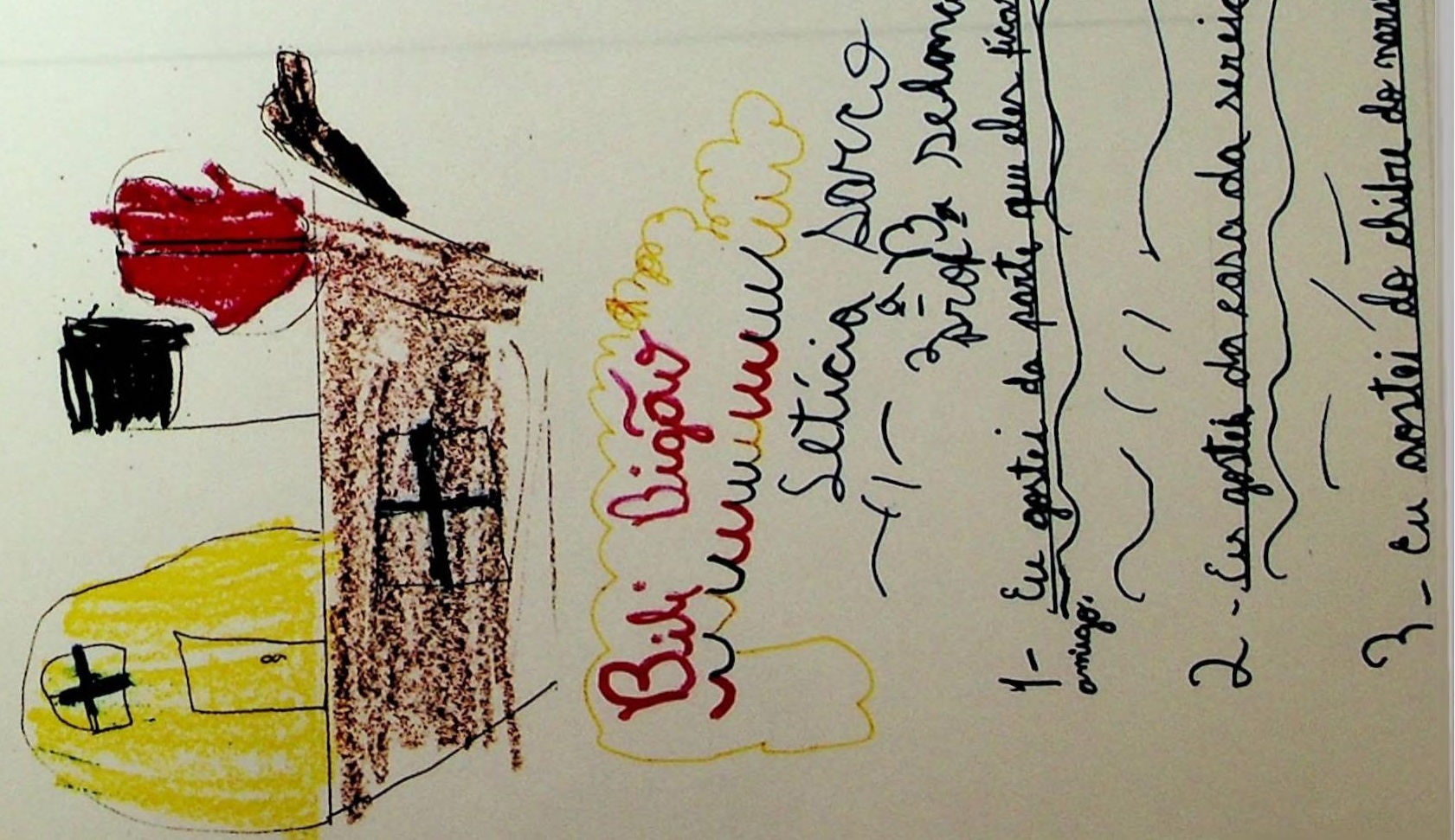




\section{Atividades das crianças:}

\section{$24 / 02 / 2000$}


PA SUAMOLIN DO Cun tro dersandra

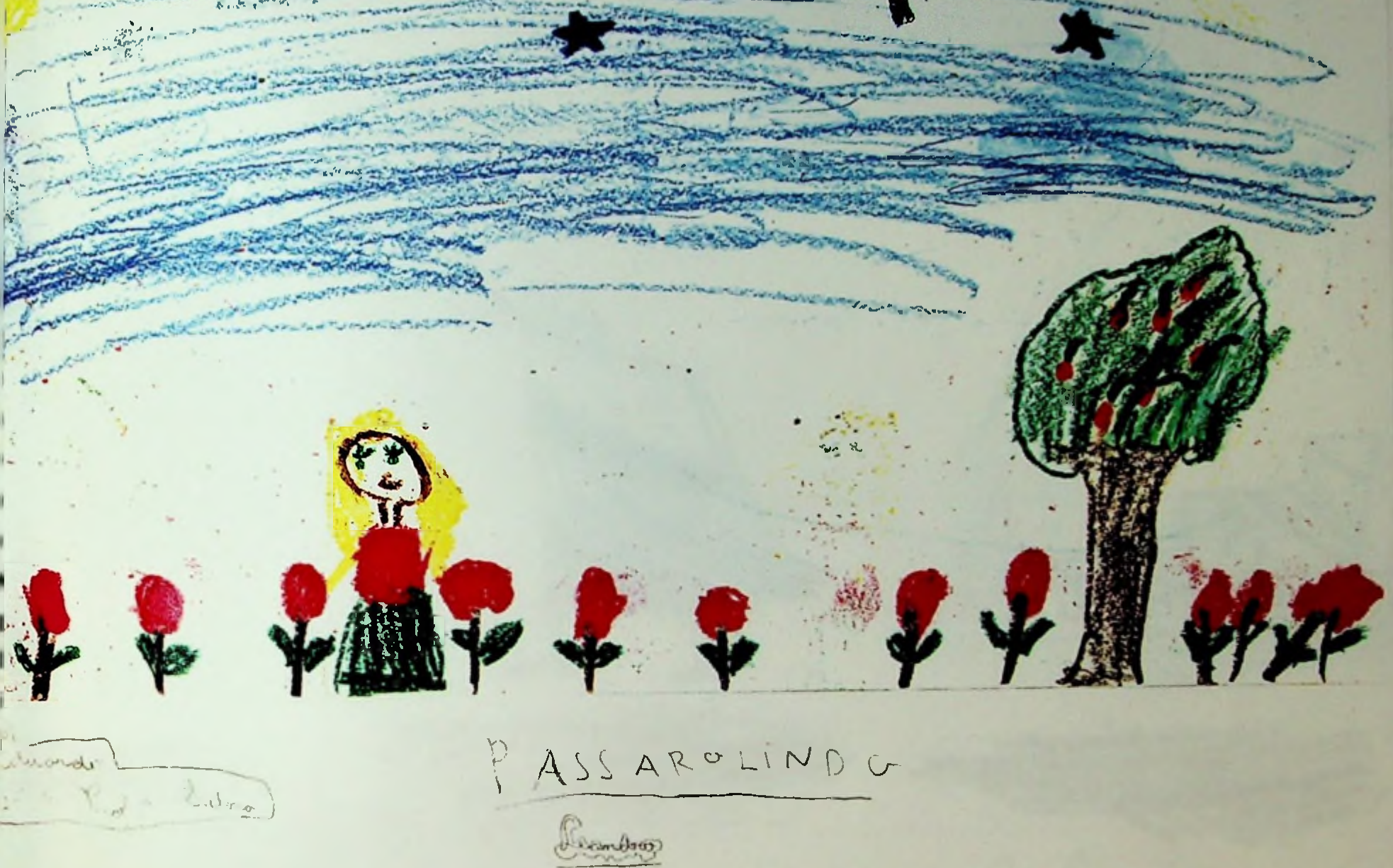

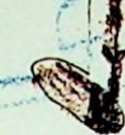

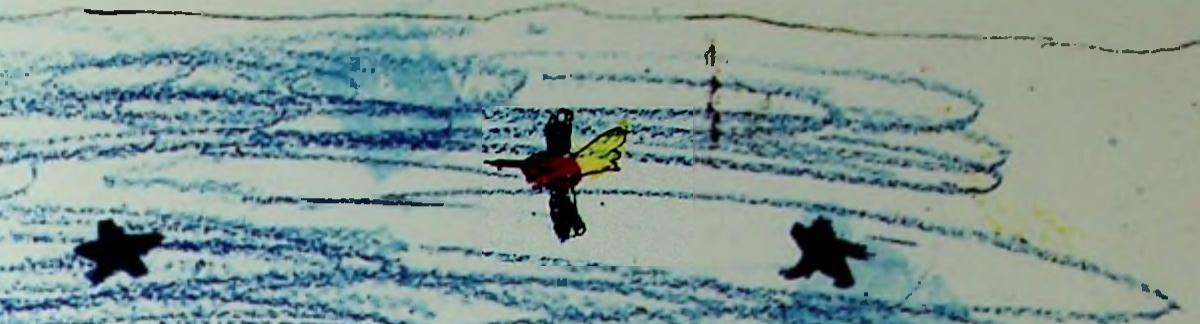

, . 

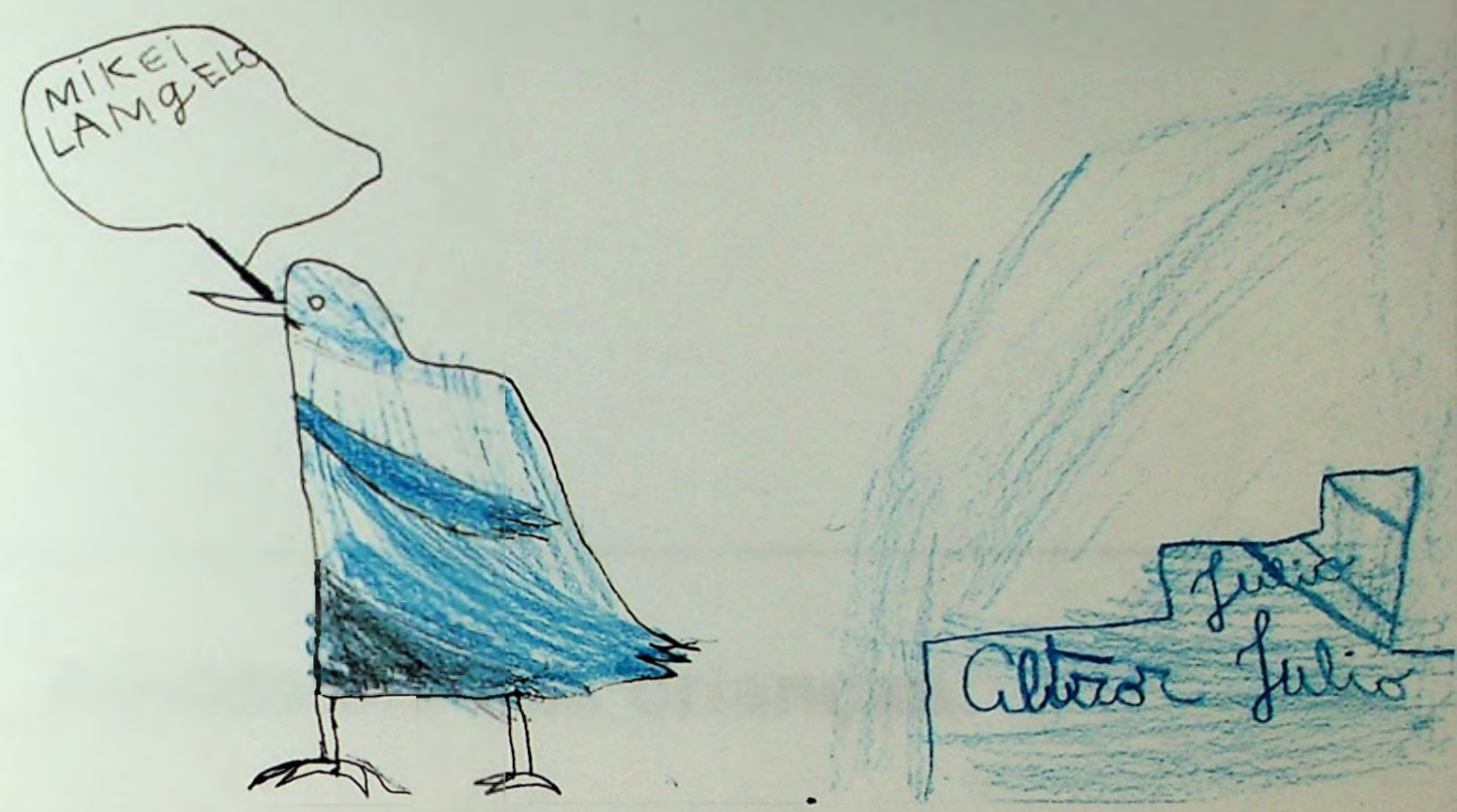

farsaralindo cardine

roxinhe o passato ele trato com os ollhos azus
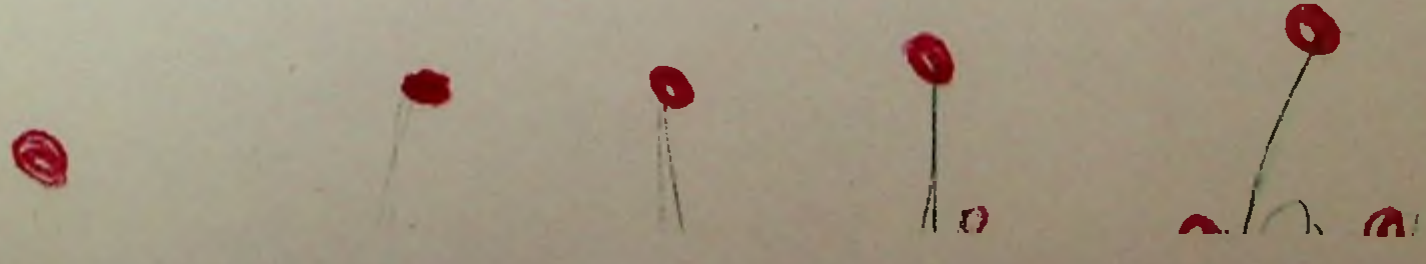

236 
Atividades das crianças:

28/02/2000 
7- Desenhe o seu amigo, ou sua amiga, ou todos os seus amigos, coloque o nome deles e escreva algo que gostaria de dizer para eles.

Caroline

Carol Karom va्a éminto legal

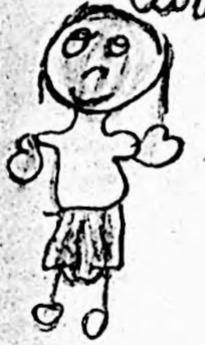

(n)

Alana
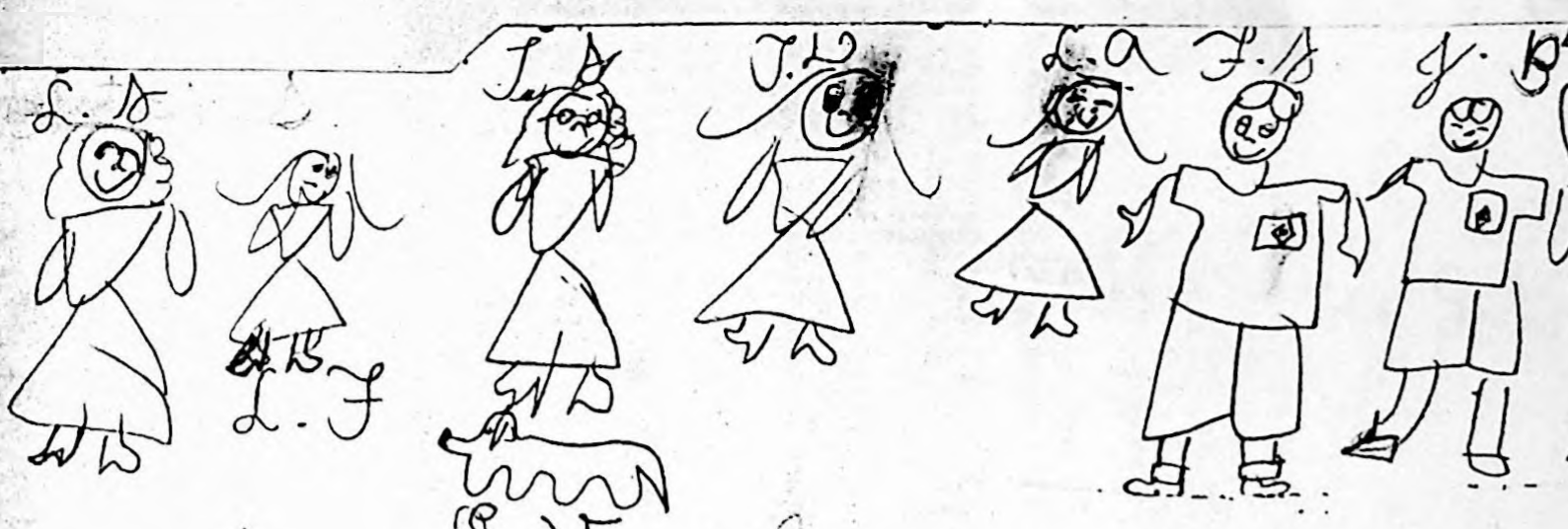

En gostor de você primo Rafhall

ETurara
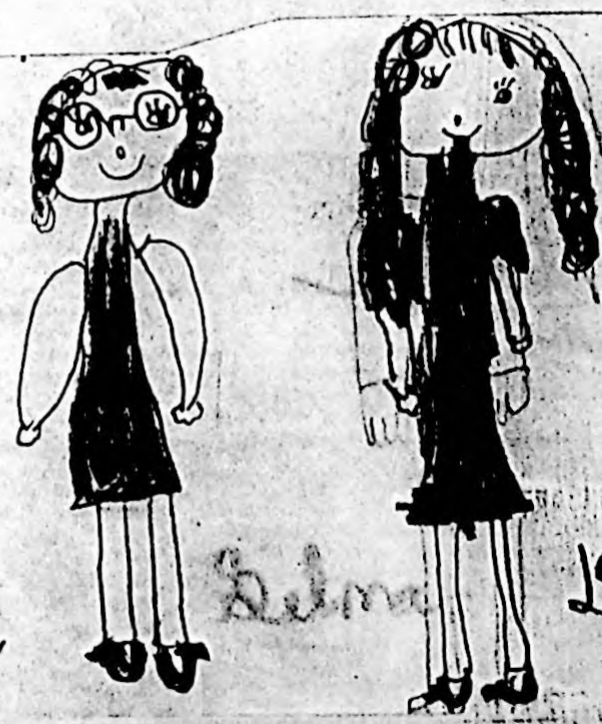

Damida

238 


Eduardo
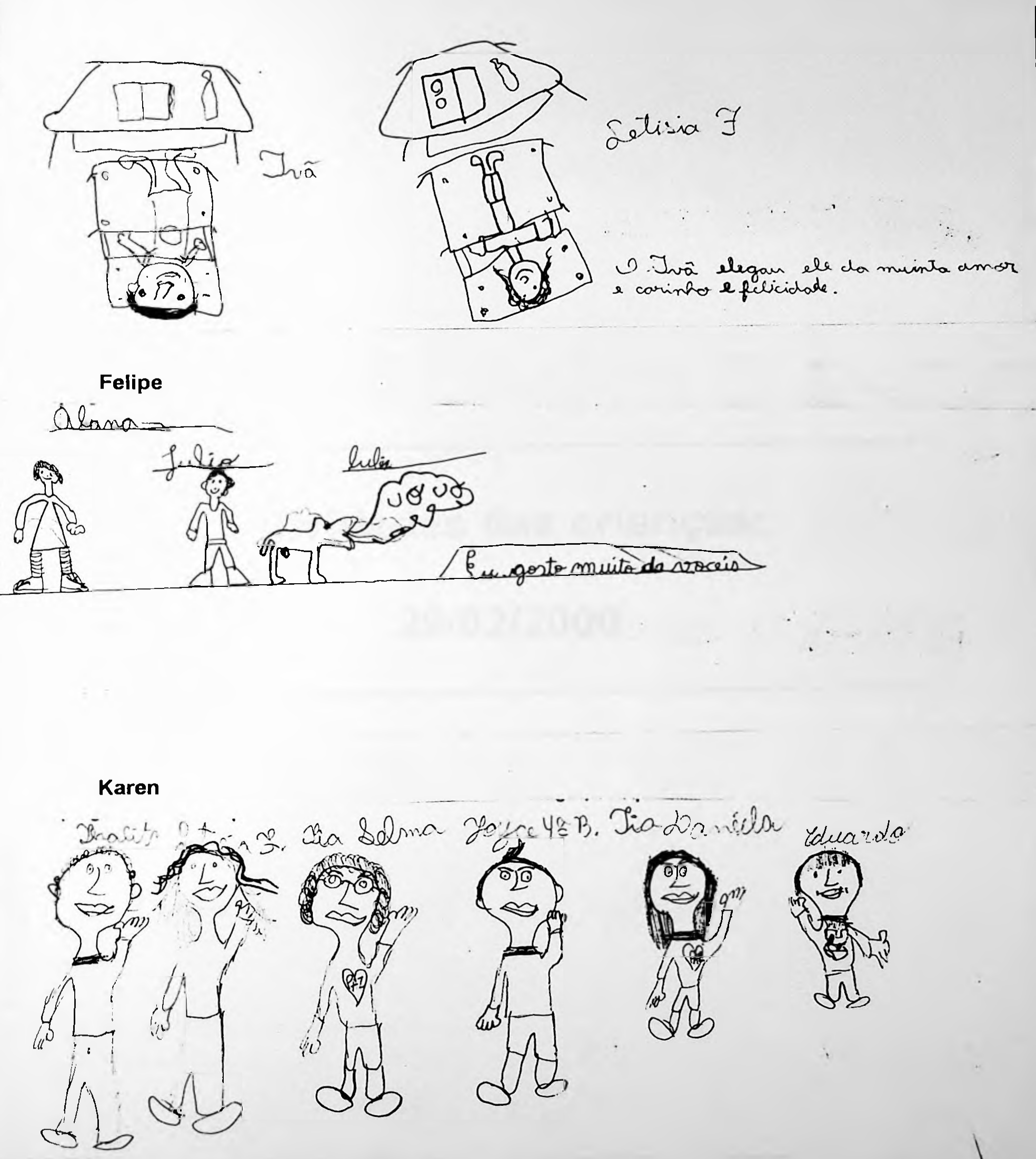
Atividades das crianças:

29/02/2000 
(1) menimge o amige

(blual' e' reu mome?

Beto. E o seu? prunno
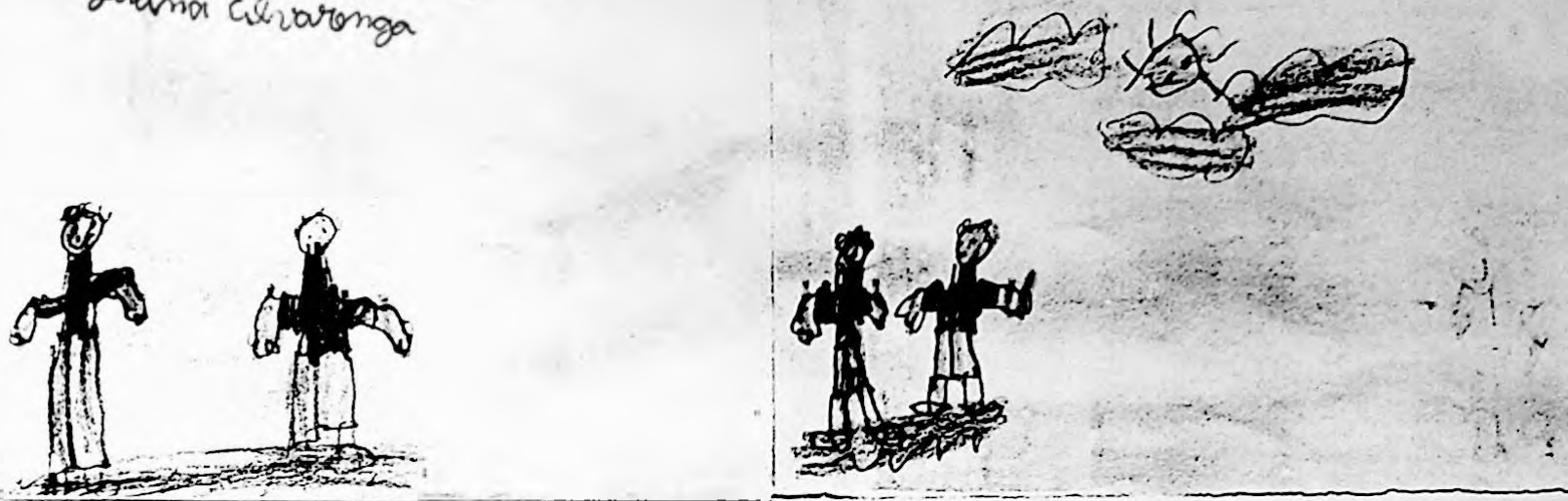

Wuer ger min convigo?

Quer dormir ma minlia casa? quero porque? Norque pra gante. minha vinal? vou pidir hiva
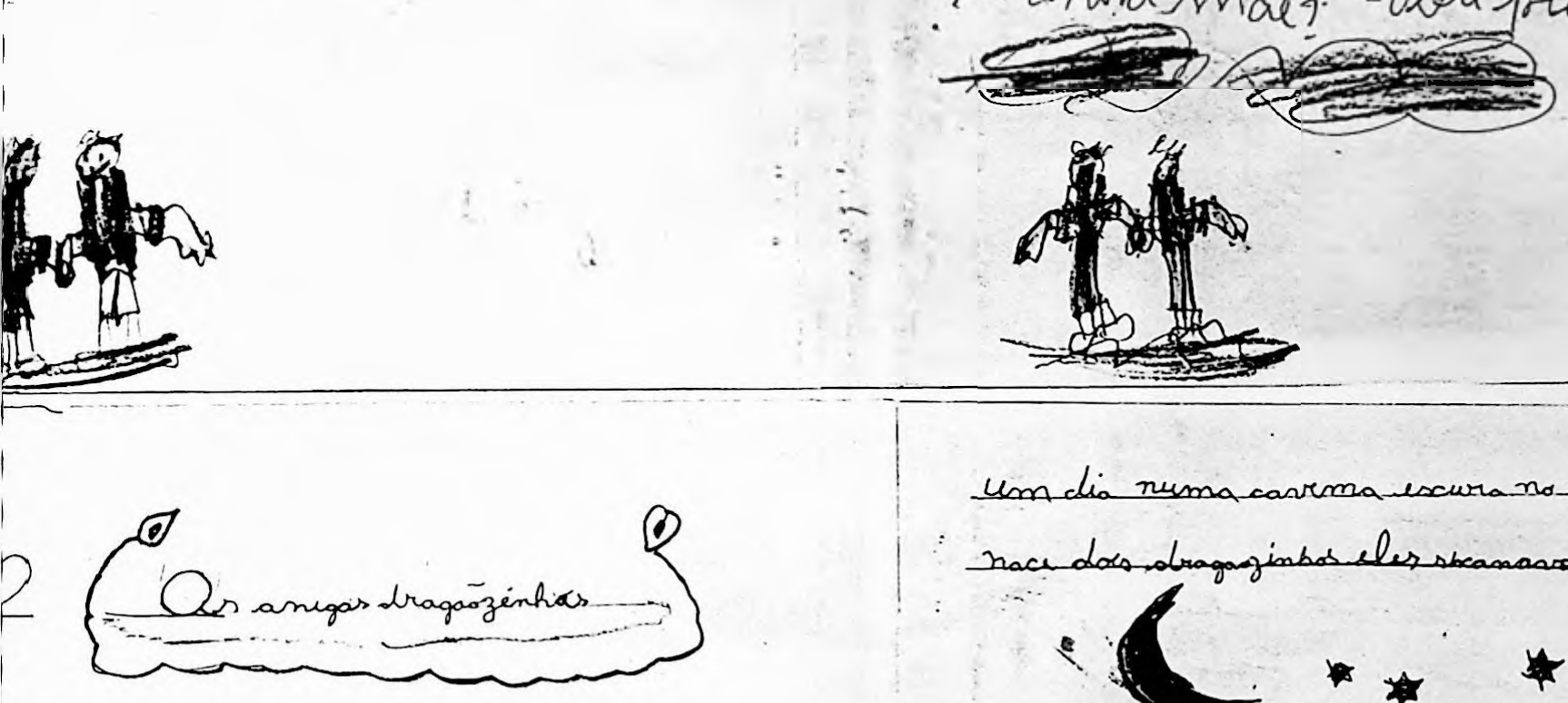

ta Brasil
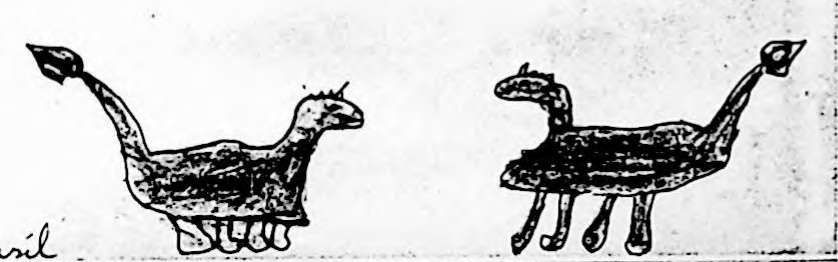

Undia numa carrema escura no mia da noste

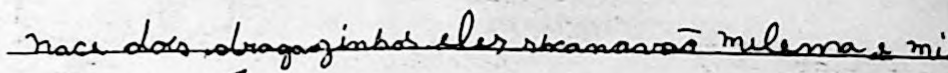
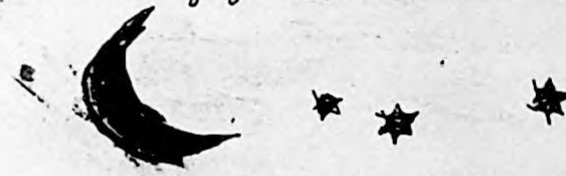

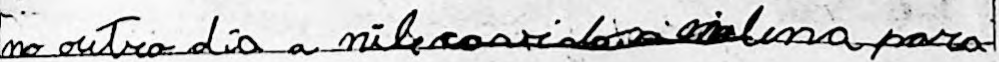
$i$ or lago vruca redupstiram muto
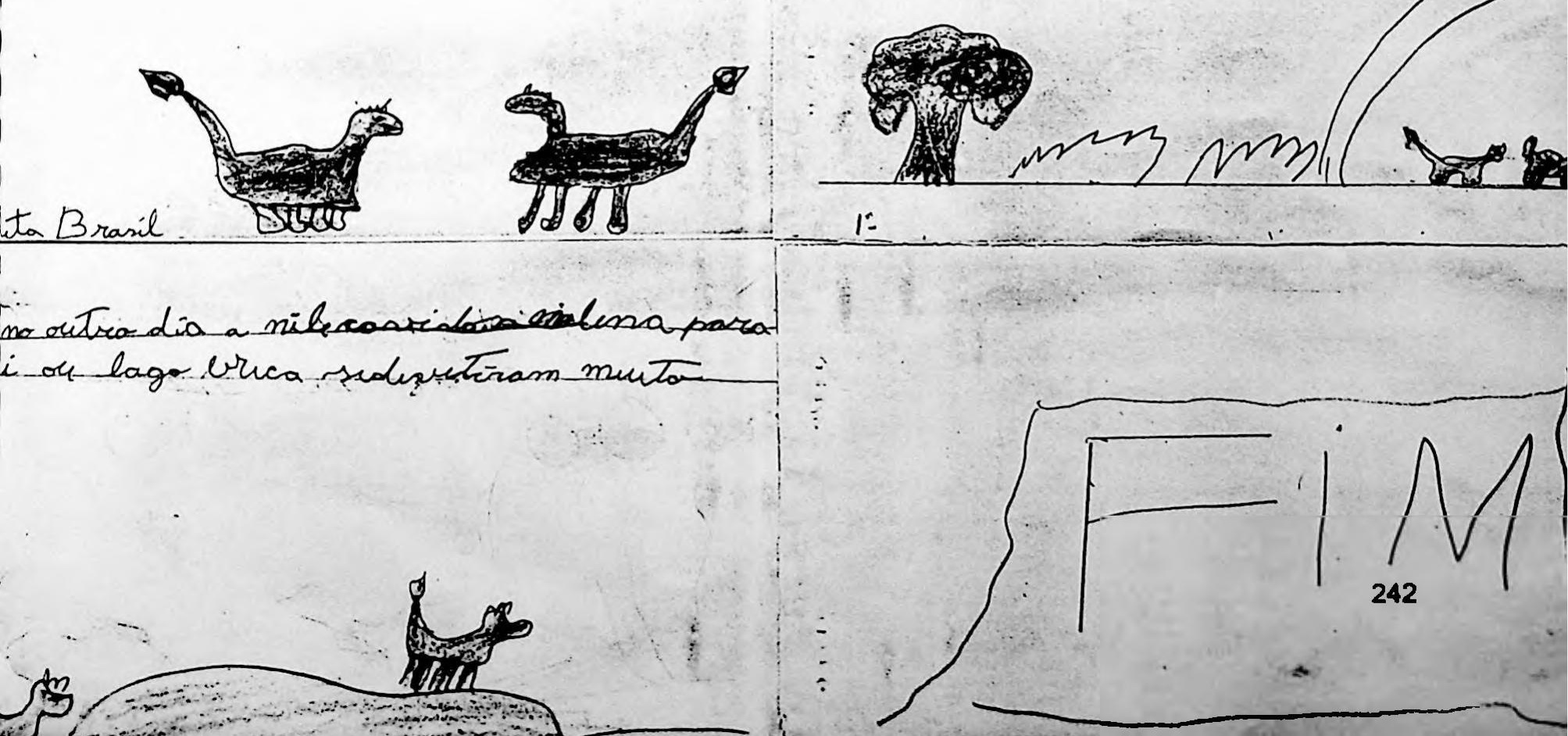
1. 


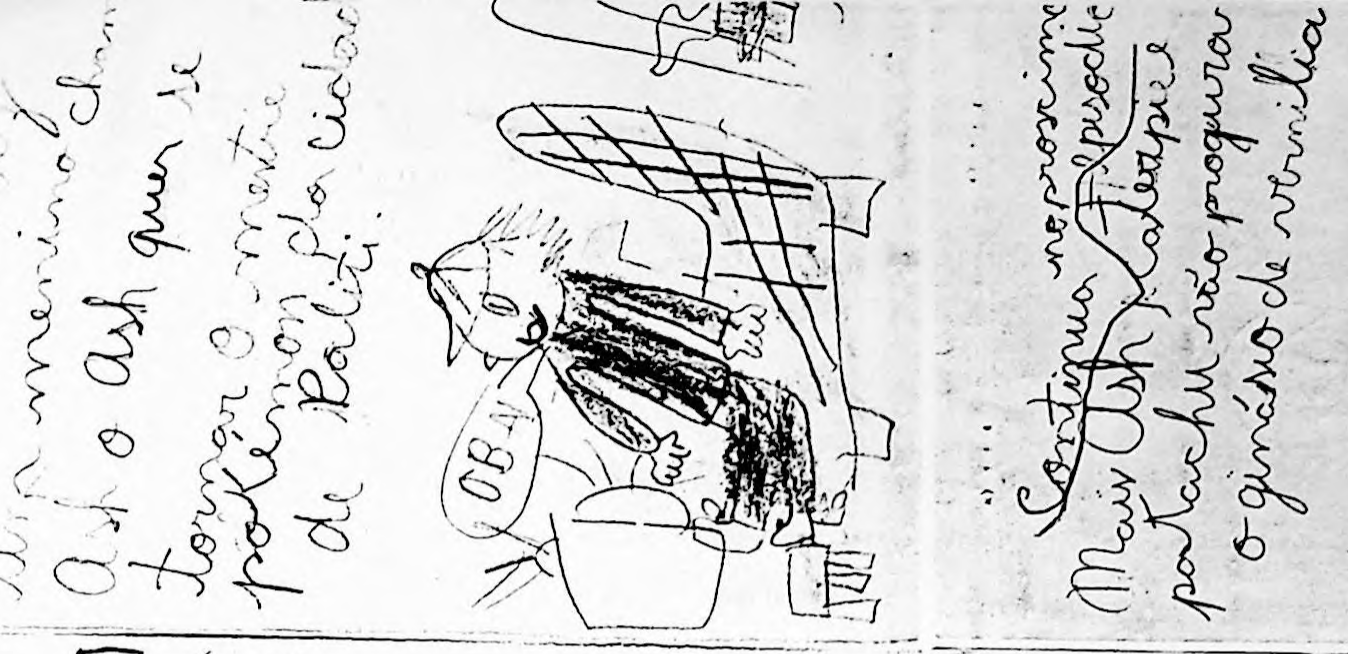

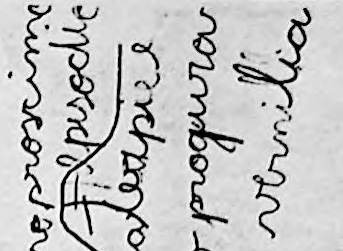

के

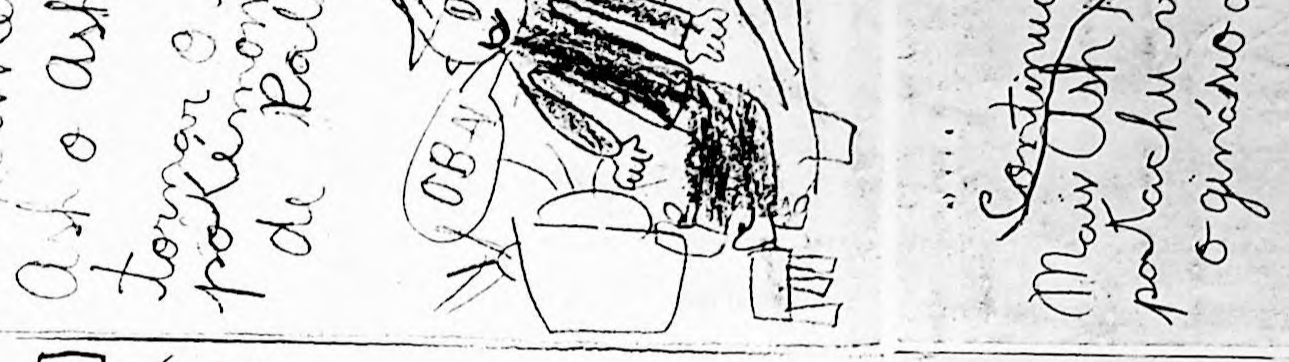
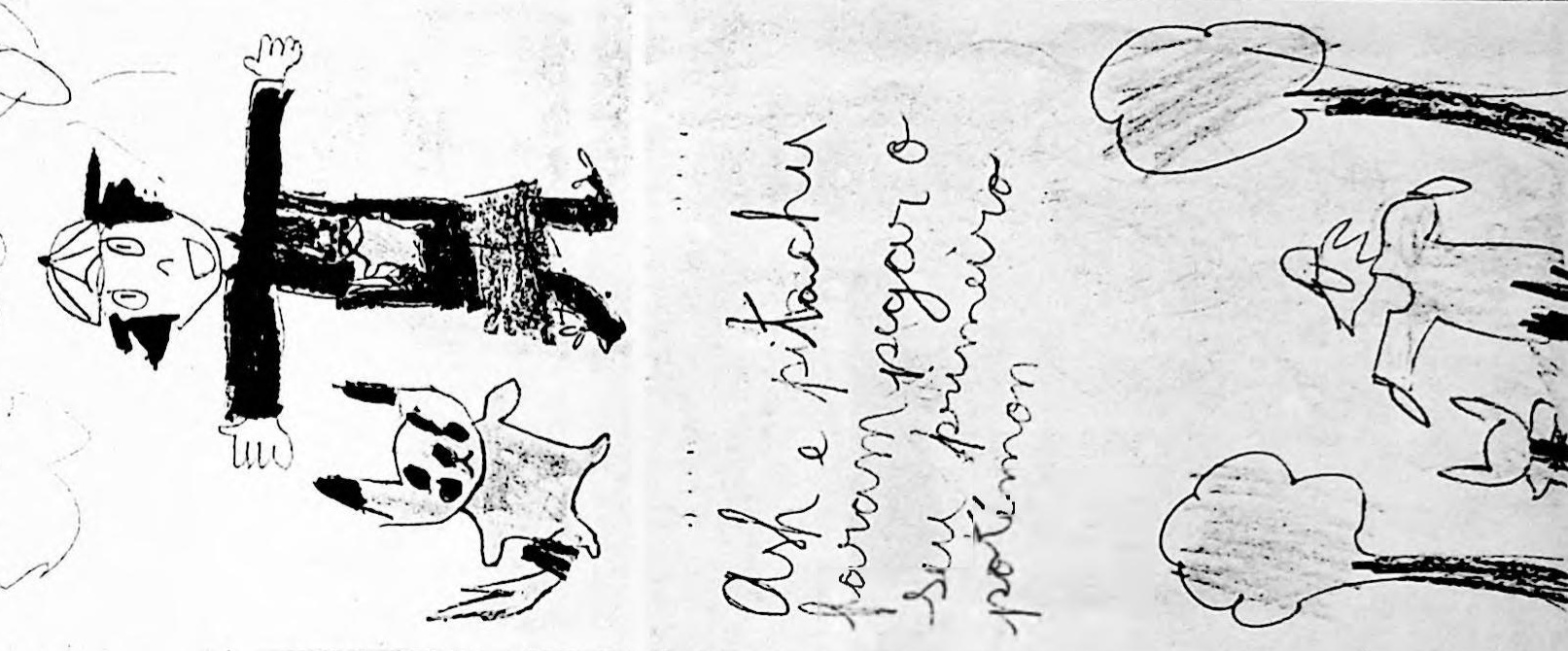

a

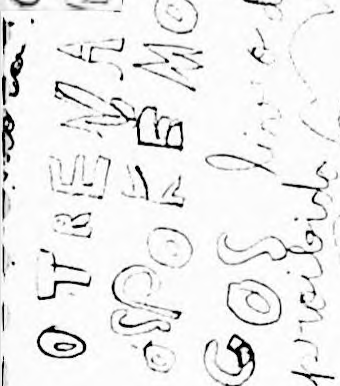

$=0$
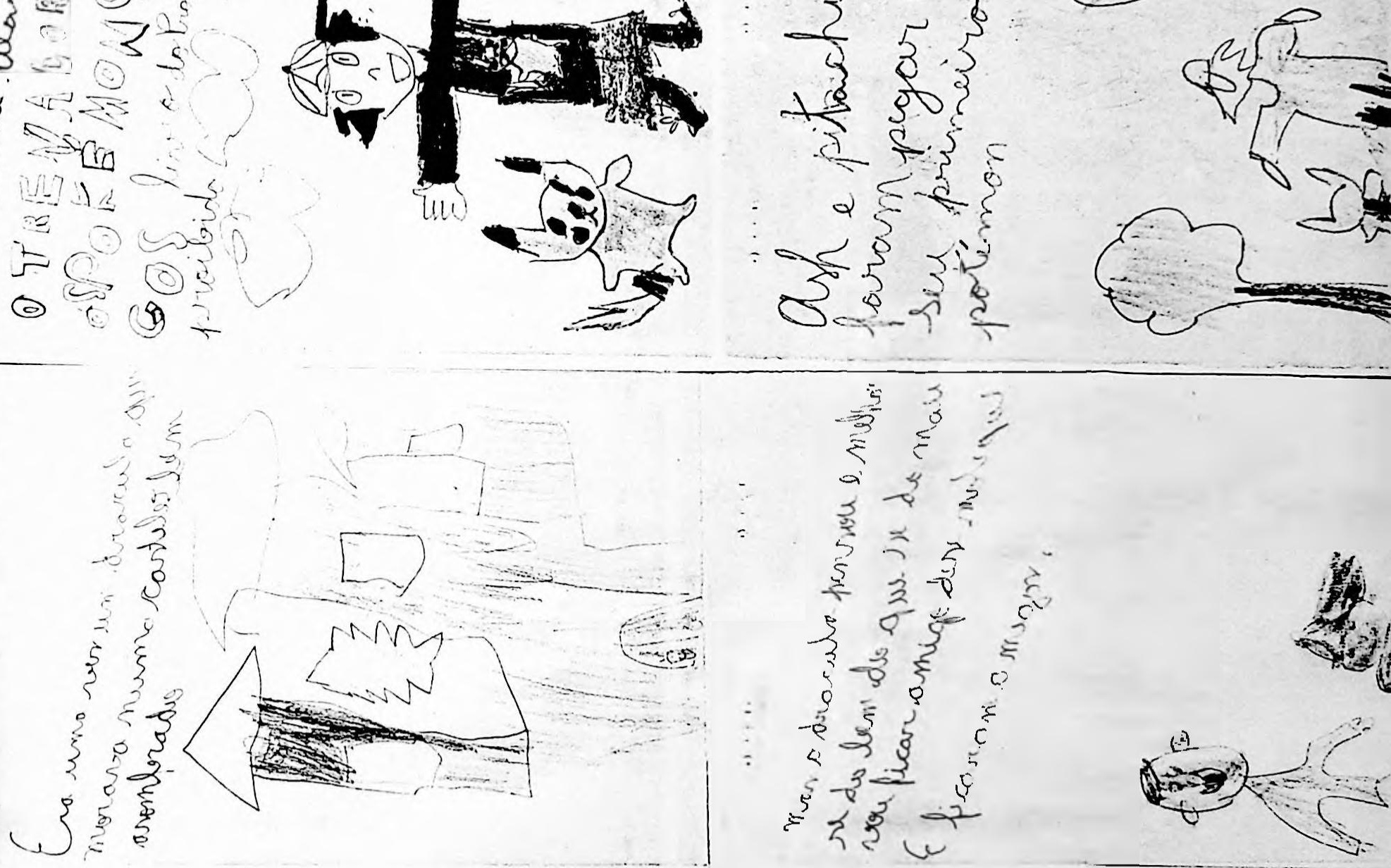

$\frac{1}{0}$
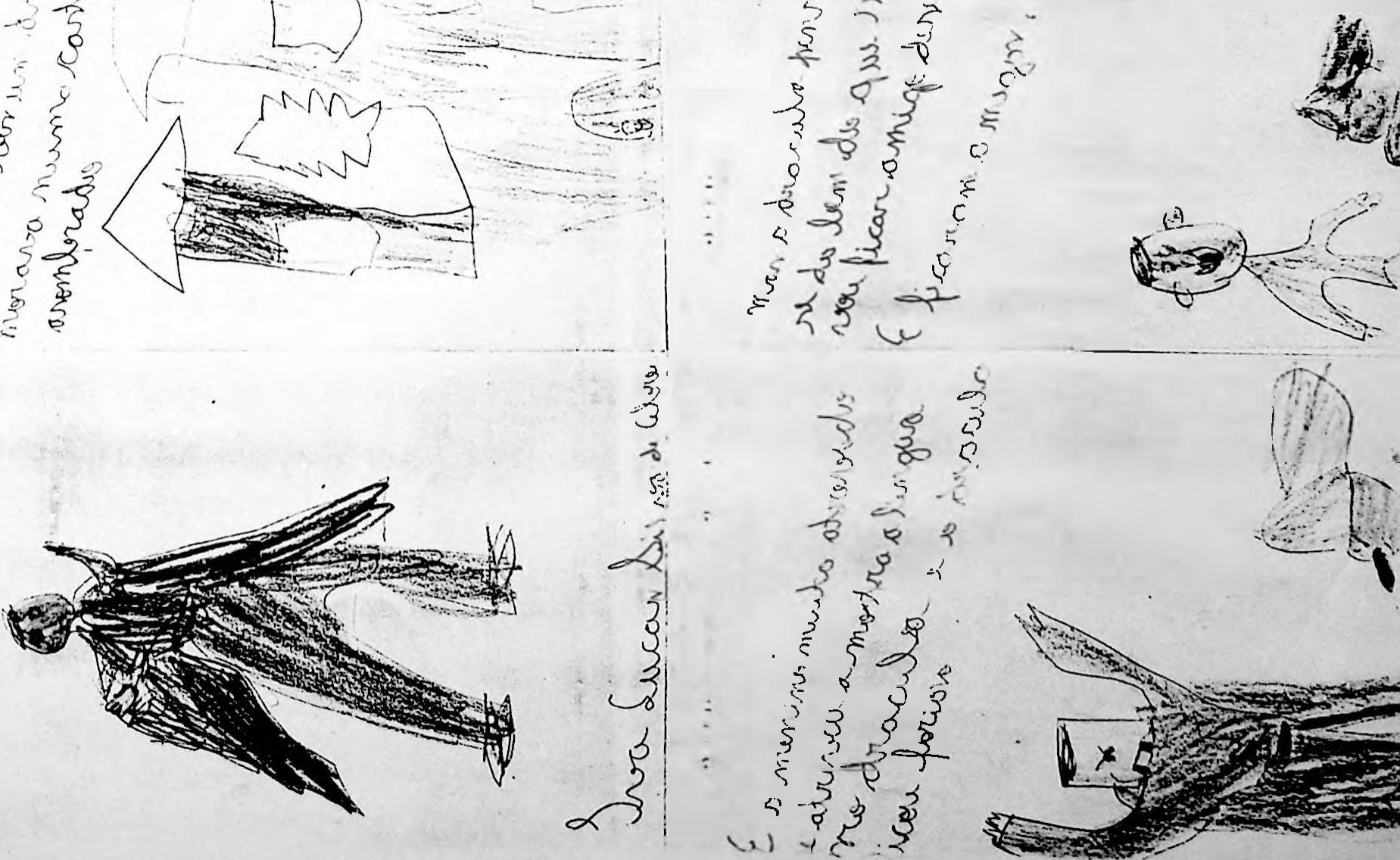